University of Rhode Island

DigitalCommons@URI

Open Access Dissertations

1985

\title{
An Investigation of the Effect of Holocaust Survivor Parents on Their Children
}

Cynthia Budwick

University of Rhode Island

Follow this and additional works at: https://digitalcommons.uri.edu/oa_diss

\section{Recommended Citation}

Budwick, Cynthia, "An Investigation of the Effect of Holocaust Survivor Parents on Their Children" (1985). Open Access Dissertations. Paper 1134.

https://digitalcommons.uri.edu/oa_diss/1134

This Dissertation is brought to you for free and open access by DigitalCommons@URI. It has been accepted for inclusion in Open Access Dissertations by an authorized administrator of DigitalCommons@URI. For more information, please contact digitalcommons-group@uri.edu. 
AN INVESTIGATTOR OF

THE EFFECT OF HOLOCAUST SURVIVCR PARENTS

ON THEIR CHILDREN

DY

CYNTIIA BUDTCK

A DISSERTATION SUMMITED

II PARTIAL FUJ PILLIPNT OF THE

DEGREE OF DUCHOR OF PHILOSUFEY

IN

PSYCHOLOGY

UNIVERSTT OE RHODE ISLAND

1985 


\section{Absiract}

Studies of the Holocaust have shown that the Concentration Camp victims were traunatized in so massive a fashion as to make a permanent and irreversible change in their character.

The purpose of the present research was to make a. direct irquixy into whether the character traits and symptoms of the survivors had an effect on the chazacter structure and persourity of their children. Eurther, it was ar attempt to distinguish two groups of survivors' children: childron of survivors who were adolescorts in tine concentratior Camps and childien of survivors who were adults in the concentration lamps.

The subjects in this study comprised a total sampla of 64 jewish jndividuals. The sample was apportionec into four groups of subjects: two experimental and two control groups. There were 16 indiriduals in each group, an equal number of males and females. The two experinental groups consisted of children of survivors who were either adolescerts or aduits in tine Concentration Camps. The two control groups corsisted of children ot Jews who escaped from Surope just prior to the Holoceust, and wo were either agolescents or adults during the second forla War. All the subjecus were provided with a brief description of the sudy, and their consent was cobtained.

There were three sources of data in this investigation: the Life History gustionaire (Appendix I), the Persoral Attributes Inventory (PAI) - a comosite of scales and subscales ir bocklet form that assess eleven personality viriables (Appendix VI) and the Structured Interview (Aprenisx Jii). 
Each of the dependent variables evaluated in the PAI and examined in the Structured Interview was analyzed using a $2 \times 2 \times 2$ analysis of variance. The three-way ANOVA assessed the effects of Camp Experience (children of survivors and controls), Sex (male and female), and Developmental Level Children of parencs who were adolescents during WHII and children of parents who were adults during whII). The responses to the Life History Questionnaire furnished demographic data and other descriptive iriformation pertaining to the barkgrounds of the subjects and their parents, and added a qualitative dinension to the study.

The analysis oi variance yielded a main effect for Camp Experience (children of survivors differed from controls) on eleven of the twenty personality atzrijutes assessed.

The analysis of variance also revealed that children of survivors whose parents vere adolescents in the Concertration Canps were no different from children of survivors whose parents were adults in the Concentration Camps on the majority of depenuent variables assessed. On]y cinee interaction effects (Camp Experience x Developmental Level) were obtained that could shed ight on the differences between the two groups.

Gther main effects and interactions rere obtained that are of heuristic value only, but have no direct relation to the Concentration Camp experierce.

The results from this study demonstrated that despite measurable differences between children of survivors and controls, the nean scores ohrained by woth groups on all deperdent varjables were within the normal range. The fact that shildxen of survivors obtained normal mean scures is strong evidence fur tieir nornality. The findirgs encouraged the concept. of a "surviver child's complex," which acknowlerges the impact of the 
sinvivor parent on his/her child, but visualizes this impact as producing a constellation of outstanding personality attributes, within the normal range that is unique to children of survivors.

The findings aIso showed that if there was any indication of a difference between chilaren of survivors who were adults in the Concentration Camps and chiidren of survivors who were adolescents in the Concentration Camps, the children of survivors who were adults were more affected by their parents' irauna.

A qualitative exarnination of the Structured Interview and the Life History Questionnaire data indicates that on most of the informal measures of Jewish identification, there is little or no difference between the experimental and control subjects. However, additional findings also revealed that children of survivors express themselves more intensely about their Jewishness than controls, view themselves as Jewish in a religious sense more than controls, and are more active in Jewish causes and issues than are controls. 
I would like to express deep thanks to iny major professor, Dr. Albert Lott, for his strong personal and professional commitment to this project. His ready availability, respect and support were invaluable. Recall of his enthusiastic response to ny ideas looned large during inevitable periods of discouragement.

I would Iike, also, to extend appreciation to my committee menDers, Dr. Al Berman and Dr. George Fitzelle. Dr. Berman, with his sharp inteligence and hunanity, has provided me with a superb model of a clinical peychologist.

Thanks, of colrse, also go to ili of the indjviduals who graciously participateci in this investigation.

Nost of ali, thanks, appreciation and iove go to ny husband, Burton, For his endurance, help, encouragement and constancy throughout my entire graduate training, and rost especially, during the course of this research project. Without hin the road to the completion of this endeavor would have deen much lonelier arid bleaker.

Finally, my children, Ariella and Seth, need to be thanked for their good humor and understanding. Exchanges with Arielia provided the germs of some of the ideas explored in this study. 


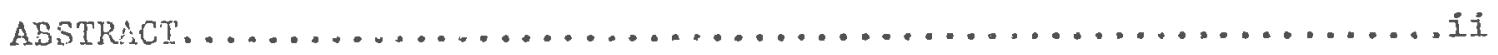

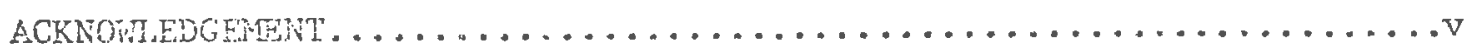

Chapter.

INTRODLCITON AND RATIONALE OF IIIS STUDY............

Introduction. . . . . . . . . . . . . . . . . . .

Retionale for this study.................

II

REVIEN OI THE IITERATURE. . . . . . . . . . . . . . . .

-The Effect of the Trama of the Concentiation......17

Carpp Experiance on the Survivors

- The Nature or Adolescence ard tre suscentibility...74 of Adolescents to Holocaust Trauma

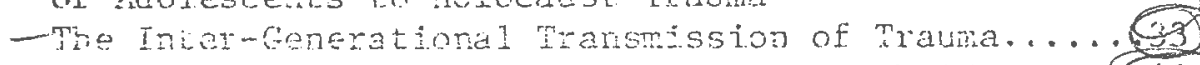

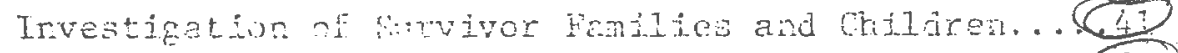

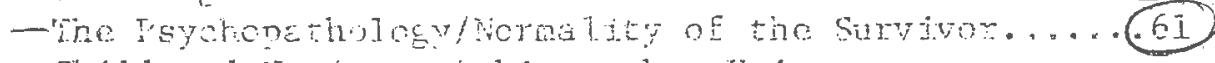

Chila and Notions of his or her Lniqueness

Wethodology of Earlier srudies................

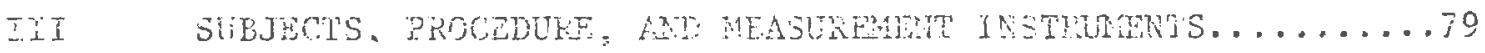

Subjects............................

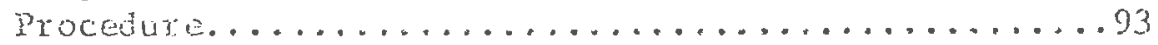

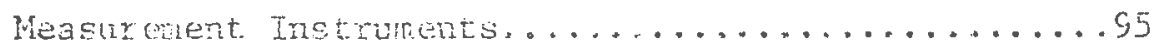

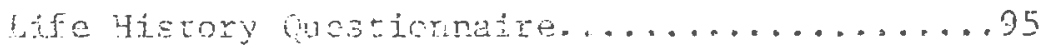

Personal Actribites Inventory (PAT) ........95

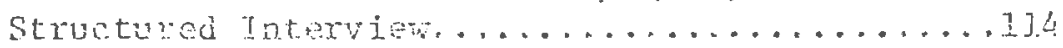

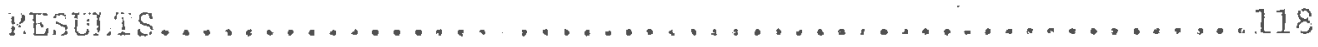

Doperdent Variabies Compriang the PAI...........29

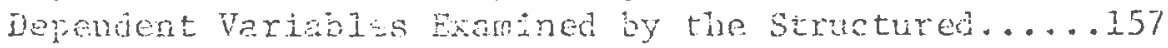

Interview

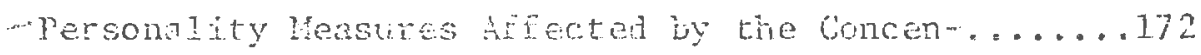

tration Cand Experionce or the parent

Personaly Yeasures not Af fected hy the.........179

Concentraticil Camp Enerigate of the perenti

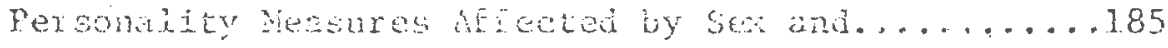

Developriental bevil

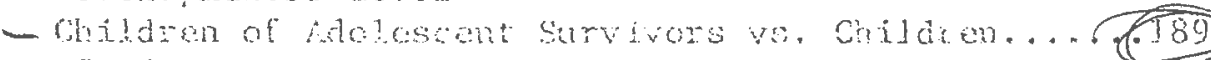
of Ainlt Survivars 
Vulnerability of Male Suryivors: Male Identity ..... I93

-Nortality of Children of Survivors............196

- Heterogeneity of Survivors and of Children........199 of Survivors as Accounted for in the Reserich

Design

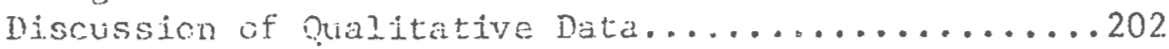

Suggestions for Further Besearch and Fractical.....210 Tum ications of this Research

\section{AFPENDICES}

I. Life History Questionaire...................211.

II. Consent Fotil (Gindaren of survivors) ..............220

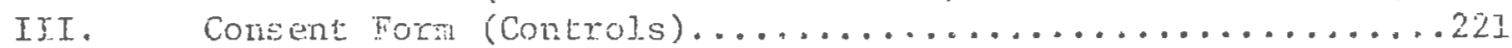

IV. Structured Interviet Gestions.................222

7. Scoring Critería and Gide...................226

VI. Fersonal Ateributes inventry................. 232

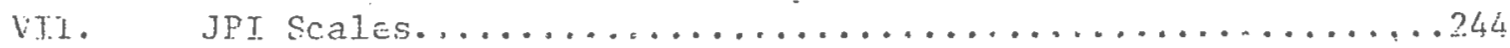

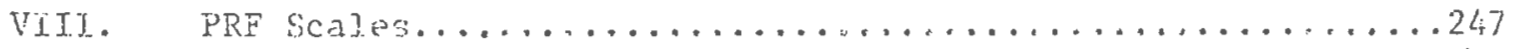

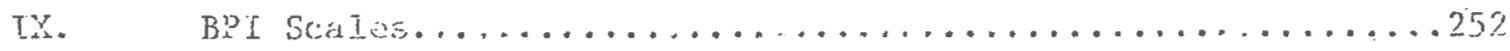

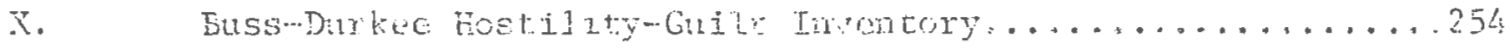

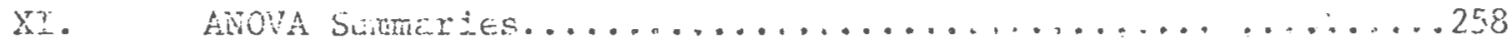

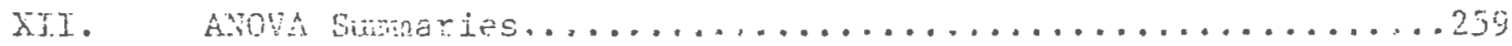

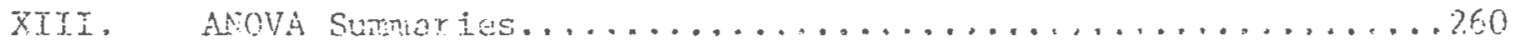

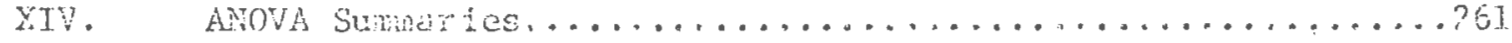

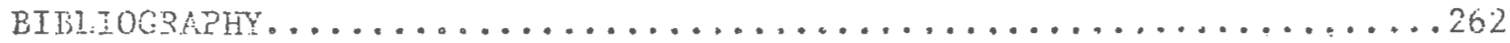




\section{INIRODUCTION AND RATIONALE OF THE STUDY}

\section{INTRODUCTION:}

The major justification for undertaking this study lies in the vital need for the empirical investigation of children of survivors of massive trauma, and particularly the trauma of the Holocaust. Interest In the psychological consequences of the Holocaust has resulted in many studies of the sirvivors themselves, but has produced relatively limited and fragmented research on the families and children of survivors. In the study of $1 \mathrm{crg}$ term effects of the Holocaust, there is a great need for objective data rather than merely subjective clinical observations.

The sma1l number of empirically based studies that do exist generally lack scientific rigor. Research findings are mainly based on small clinical ("pathojogicai") samples and methodology is often uncertain. Problems of bias, matching and definition of terms prevail.

It is only recently that the children of Holocaust survivors have matured, and have begun to present the mentai health comunity with their unfụue jssues, problems and vulnerabilities. About ten years ago, psychotherapists bagan to notice a relatively large nimber of children of Holocaust survivors among thetr patients. Ine comon issues that have been presanted and the specific problems that have been reported raise guestions concerning the effects of Concentraticu Camp survival on the second generation.

This; study is concerned with two Lssues, one gencral, the other specifjc. The general. issue is that of tire riassive trauna of the Holow caust a transmitced to the second generation. The specific issue is the differential effect on the second generation of the age of the 
parents when they were trauratized.

Research on the specific issue of the age at which the parent was traumatized is important for several reasons. First, it can provide answers to important questions in developmental psychology. Second, it can confirm or deny the hypotheses set forth. Third, it can aid in the generation of new hypotheses concerning the effects of trauma and their transmission. Fourth, the research results can reveal the personality characteristics of the adolescent and the adult that are most affected by trauma. Fifth, the results of this study can affect the current thought concerning the titning and type (discussion groups, brief therapy groups, multi-family groups, multi-generational mixed or homogenous grcups, faraily, individual, residentiel treatment, etc.) cf psychotherapeutic intervention, and ideally could aid in preventing transmission of pathogenic traits from one generation to the next. The conclusions of this rcsearch can help to cleariy define the issues that need to be focused on in psychotherapy with children of Holocaust survivors.

Research on the general issue of the effect on the second generation of trauna due to the Holocaust will deepen our understanding of the con-seçences of other types of trama and possibly aid in the prevention of those consequences.

The issues of prevention and treatment are espectally significant. As enphrisized by Barccies (1973), "The process by which the Concentration Camp Syndzone fis transmitted and perpetuated in children of survivors is highiy conglex and faschiduting ... It ts hoped that research in this area will generate a clearer understanding of the dynamics and suggest treatuent probibilicies for chiliter of survivors." . . .

"Pofessionaj. help still. remains sne of the most potent ways of attempting 
to halt the transuission of destructive and ralignant residues of the Holocaust from one goneratiori to the riext." (Barocas \& Barocas, 1973 ). And stressed by Sigal (1971): "We can often retrospectively trace the effect of peychopathological functioning of one family through two or thiree generations. It is therefore quite possible that the consequences of both massive and cumulaive trauma will nct stop with the second generation, but will continue to be felt for an unknown number of subseguent generations unless some preventative neasures can be found." Danieli (1980(b)) says that "Understanding the transmission of pathologicai intergenerational processes should contribute to our finding effective ways for preventing their transiniseion to succeding generatjons." Solknff ([9S1) notes: "Ihe implicit goal for investigators in this area is the introduction of primary and secondary prevention prograsıs."

Russe11 (1974), Sigai (1971) agoin, Jeplowitz (1973), Newan (2979) anu Barucas \& Perocas (1979) concur. with Danteil and the otilers. 
IUATIOLALE FOR THIS STUDY:

Studies of the Nazi Holocaust have shown that Concentration Camp victims wers troumatized in so massive a fashion as to make a permanent and irreversible charge in their character. The qualitative change in personality was a relatively consistent one (although the degree of change varjed) and took piace irrespective of character structures or personalities prior to Concentration Cairp experierce. This change in personality or character, and typical accomanying symptoms were termed the Ccncentration Camp Syndrome. Research on the effects of the Concentration Camp experlence on survivors, and on the Concentration Camp Syndrome itself, has emphasized both that adolescents were rore profoundly affected by the Concertration Camp experifence than adults, and that they evidenced the Concentration Camp Syndrome to a more obvious degree. Thcories of adolcscence confirm that the esotional upheaval. and sensitivity characteristic of that developmental stage predisposes the adolescent to react to environmental change in a inore lasting, duffertoty deeper, and intense manmer than adults.

This study is an attempt $c 0$ make a direct inguiry troto whether the- lef character traits and symptons of the survivors had an affect on the

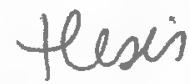
charactex structure and personality of their children. Further, it is an attenpt to distinguish between two groups of survivors' children: children of survivors who vere adolescents in the Concentration Camps, and elifdren of survivors whe vere adults in the concentration Camps. It is the researcher's hypothesis that children of adolescent survivors wil display lese adaptive ways of coping than chilaren of adult sur- 


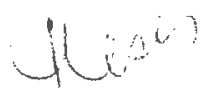

vivors as measured by the majority of those personality variabies found worthy of direct study in both groups. On several of the variables selected for study (interpersonal affect, creativity and social activism), however, the adaptive mechanisins of the children of adolescent survivors nay equal or surpase those of adult survivors.

A second hyporhesis is that both survivor groups will be significaitly different from control groups on the variables studied. This study will be in addition an indirest effort at questioning the premise that there is a personality. difference aftex the Concentration Camp experience, between aduit ard adolescent survivors. It will also be an indirect explcration of differences in personality functioning between survivor parents and cortrol parents.

Although this researcher's hypotheses are based on the body of literature on lolocaust survivors and their children, previous research has provided us vith a inited number of well-controlleci methodological1y sound studies on non-clinied populations. Becanse few studies bear resemblance to itis researoh, fuil-blown predictions based on the hypotheses cannot be nade. Differences anong the groups are expected on the various variabies, but precisely what they will be camou be predicted. The ditferences an energe only from the research.

The variables to be studied were chosen on the basis of a number of indicators. First, a study wes maie of the characteristics of the post-trauma pexsonality of the adolescent and adult survivor. On the basis of this study aud gided by psychodymamic theory, those traits that survivoss chjldyen would be nore ljkely to have vere decided upon. In addition, fandiarity with the generab charactcristics of the adolesw cents" pasonality, facintated the highlighting of those aspeats of hts/her personisloty nost vulnerghle to twauna. The major assunption is 
that the traumatized adolescent would then, as a parent, transmit the effect of trama to his/her offspring.

The eximination of the very few studies done on children of survivors afded in the final selection of variables for consideration. The variables thet were selected for study were 1) alienation, 2) social activism, 3) faith jis people (trist), 4) depression, 5) succorance (dependence), 6) autonory, 7) interpersonal affect (empathy and capacity for warte interperconal relations;, 8) innovation (creativity), 9) hypochond:iasis (sonatization and bolily preoccupations), 10) abasement (guilt ank masochism), 11) hostility, 12) anxiety, 13) fear (phobias), and 14) sexual identity.

A. Alienatiol:

For wany reasons (inabjility to face guilt, discomfort, etc.) accounts of the Holocaust by survivors were not attended to by the society around them. This intensified their already established sense of isolation. To ameliorate this feeling of isolation, survivors attempted to fom bonds with others like themselves. This, homever, only separated them from the general. socicty, anu tendel to isolate them even further (Danieli, 1980). Mistrust and fear of the outsicie world, as a result of Concentration Camp experiences also increased thejr alienation (Daniali, $1980(a))$. Finct are indications that this feeling of alienation was comminated to the survivors' children (Kinsier, 1981). The child, it was thought, was made to feel distrustful of the outside world, and confortable only in lis/lner home. Identification of the child with the parent. must also be taker. into acount. It is easy to see how a child might have identified with an alienated parent; and in turn becone alienated. Sigal, Silver, Rakoft \& illin (1973) found the survivor crild hich 
on anoric and alienation scales.

\section{B. Anxiety}

Chronic, sometimes overwhelming anxiety (Niederland, 1968; KrystaI

\& Niederland, 1963; Newnan, 1979) is part of the symptomotology of

Concentration Camp survivors. In addition, survivors are documented

to have been overly anxious, ovexly cancernad parents (Newman, 1979).

In identifying with their parents, it is rather Iikely that survivors'

children identified wich their parents' anxiety. While overprotective

of their children in sone areas, survivors vere known to often be neg-

lectfui of their childrens' emotional needs. They also tended not to

set sufficient limits on their childrenc' behavior (Russel1, 1974). Both

thesè attitudes might have easily provoked anxidy in their children.

Finaliy, it has been discovered that survivor parents beld very ingh expectations for their children (Trossman, 7.968). Children often sufferad under these expectations, beconing anxious at bejng unable to neet then.

c. Interpersoind. Affect (Enedby, Caracity fos Warm Interpersonal. Rejarions)

'The survivors' chijdren were brought up to be concerned not to hut their parents. As children they were exquisitely sensitive to their pareats' peln and nood changes (Danieli, 1980). Jhey have shwm extraordinary sympthy for their paxents' unexpressed guilt and suffexing (Newnan, 1979).

As adulis, a large percentage of survivors' children have gone into the ilelping frofessions (Danteli, 19S0; Savran, Beila, persomal commication). We might gupse, then, that survivors' children are 
more empathic than average.

\section{Iypochoncriasis (Sowatization and Bodily Preoccupations)}

Physical and material survival were chief concerns in survivor parents' lives. Nutrition and body care were frequent preoccupations of theirs. Illzess, actual or fantasized, was in the air. Somatization becane an unconscious exprassion of the survivors' chronic rage and grjef, and was often used to control anả manipulate other family nembers (Danieli, 1980). So pervasive a style of coping likely filtered down to survivors' chjldren, and became one of their preferred modes of handiing depression and aggression, and of achieving power over others.

\section{E. Faith in People (Trust)}

"Disester smert" survivor parents preparad their children for any eventuality of living. The children were usually taught never to be caught off--guard or defenseless in any way. It is reported that they were taught to distrust others and to be fearful of the outside world so as to keep the family a closed system (Danieli, 1980). Thus survivor parents in many cases maintained a suspicious and hostile attitude towards the Gentile rorld around then, and expected their children to do the same. The child, then, may have become mistrustful and suspicious like his/her fearcuts. A further reason why the survivors' child may be uilable to trust others is related to the fact that the Concentration Canp survivor parent was often depressed aud withdrawn during his/her child's infancy. This parent therefore did not have the capacity to inspira basic: trusi in his!her child (Lipkowitz, 1973). 
F. Tear (phodias)

'The generally overprotective survivor parents are said to have consistently warned theiz children of impending danger. Although this is understandable since many had lost previous children and had witnessed death so frequent1y (and were therefore constantly arvare of their vulnerabijity and how close they had cone to death (Barocas, 1973)), mary survivors' children may have becume moderutcly phobje (îrosman, 1968).

\section{G. Abasensizt (Guiliz and Yascchism)}

The survivors' guilt ('Why did J live and others die?') was everpresent, and was sonehow communicated to their chjolren. Major ani ninor setbacks, frustrations and failuies in achievenent of thej. goals freguently precipitated disproportionate guilt reactions in survivor children. The survivor fanily stmosphere facizitated this experience of intense guile feelings and deprossive raactions un the part of tire children ir general. (guizt was often usal as a means of contiol), and i.n particuiar, faidue meant to the child that he/she was incapable of the task of valuating lisiner parents existence with his/her accompisinrents (Barocas \& Baroca, i9;9; Barocas, 1972; Kinsler. 1931).

Cinidren of: survivors have been discoveres to often feel guilty about thejr bekavior towaris theju parents. They feel guilry for being "ungrateful" to paxtes who, in their ow way, gave their chicdren a great deal (Danieif, 138j; Sigii, 1971 ). They ireguentiy feel gujity fnj not Ijving op to their perfits' excessive expectations, and for

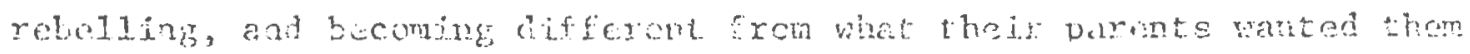
to be. In an attenpt to undo the Holocaust. for their parents, Burvivas: 
childsen often fund that they cantot comfort their parents enough and cannot possibly compensate for all of the lcsses their parents have had to encure (Fogelman, 1979). This rasults in a pervasive sense of guilt. In order to relieve themselves of guilt, says Newnan (1979), many survivors' childxon take on the need to suffer, and even attempt to rival the parent in the extent of their siffering.

Finally, Kestenberg (1972) noted that guili and shame were major reactions of sumivors' children to their parents' persectition.

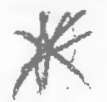

\section{H. Depression,}

The home of the child of the survivor was, in many cases, characterized by pervasive depression. Conditions in the camp had made it: impossible foi the survivors to mourn, and a consequence of the failure to mourn was a never ending depression. As a result, the children of survivors found thenselves ncuming on behalf of two generations: thejr parents and themselves (For İass of their closest relatives other than their parents). Survivor mothers, than, were frequently depressed. In addition, studies found, they were so preoccupied with thenselves and their past (Sigal, 1971) that they were unable to give time and attention to their children. They were ofteñ unable to tolerate the enotional demands made on them by their chiidren. The combination of these two elements imparred the ability of many survivors to nurture their childrell. These children who suffered from affective neglect tended t:o become depressed adults (Wiederland \& Krystal, 1968).

Two other factors nay account for depression in the ehild of survivors. The first, relating to identification, is that the process of nomal development allows for the iantification of the chiid with his/ 


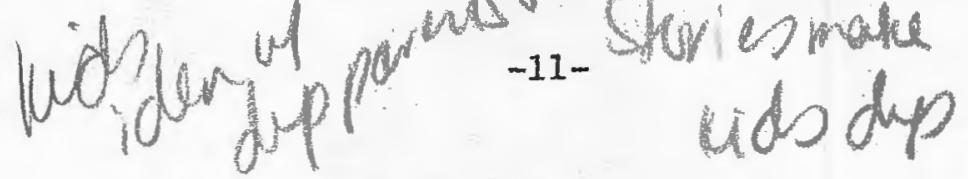

her parents. If the parents are depressed and emotionaily depleted as the survivor parents are alleged to have been, the child will also be depressed (Sigal, 1971). The second factor concerns the response of the surviver child to tales from his/her parents' past. It has been suggested that continual exposure to Holocaust. stories results in depression on the part of the survivor child (Trossman, 1968).

What the chidien of survivors may often expexience as depression is, in fact, blocked aggression As previously mentioned, the survivors' children had difficulty rebelling agairst their parents and have trouble rejecting unfair parental expectations. Frustrated and angry, they tend to turn the aggression jnward ard become depressed (Nerman, 1979). Barocas (1973) confims this view.

I. Autonony and J: Succorance (Dependency)

Lipkowitz (1.973) in his discussion of separation-individuation nentions that an infant must gradually progress from the original symbiotic relationship with his/her nother, to the separation-inuividuation phase. The separation-individuation phase must then be properly negotiated to insure that the individial's developrent proceed normally.) For this to occur, normal cueing between mother and child must take place. It is in this area thet the survivor motheir is said to have been greatly handicapped. Isurdereo by guilt, tension and fear, she could not aid in another separation (separations were vrequent traumatic occurrences in the Concentration Camps and cued For symbiosis (Bergnann, 1982). In addition, fof from an Eriksouian point of wiew, the chronically depressed and withdrawn survivor mother was unabie to inspire basic trust in her infant. Witlout a sense of basfic trust, tie capacity rill not deviop in the child to 
progress unhindered, beyond symbiosis with the rother.

We see, then, that because of the many losses that survivor parents have sustained, relationships with tleir children often become very dependent and clinging. The separation that accompanies adulthood is especially difficult (Fogelman, 1979) because of theix overinvolvement with each other (Newman, 1979).

In adulthood the survivors' children often seek a degree of oneness (similar to their relationship with the survivor parents), which is inappropriate and handicaps them in their interpersonal relations. Moreover they are extremely "sensitive to real or inagined loss experiences, and many difficulties arise when they attemt to enter into and sustain close relationships outside of the family." (Barocas \& Barocas, 1979).

The survivor's family, therefore, was characterized according to researchers by enmeshnent. Survivor perents" for whom overly close parent-child relationships compensated for abandonment by their (the survivors') parents (Krystal. \& Niederland, 1968) regarded the establishment of boundaries of chy kind by their children as a severe threat to the intactness of the fanily, For survivors, separation was synonymons with tota1. and permenert 10ss. Therefore, their children were discoraged from and condemneo for any assertion of autonomy (Kinsler, 1981), independence, healthy rebellion, or desire for privacy. Intrusive survivor parents responded to this nornal and approprote behavior as acts of disloyalty, ingratitude, betrayal and abandonment (Danieli, 1980; Krystal \& Niederland, 1968). As a result of this discouragement of Initiative, sunvivors' chilcten are often urable to face basic adult responsibilities (Fogelmar, 1079). 


\section{R. Aggression}

Management of rage and aggression has been an enorwous problem for the survivors. The survivors' rage has several sources: firstly, during the var, aggression against the enemy had to be controlled; secondly, the survivors felt rage toward their parents because they felt abandoned by them; and Iirally, as a regressive defensive measure, they frequently identified with the aggressor. After the war the outlets for the survivors' bottled-up aggression were inaciequate. Frightered of their rage, it was manifested partially and indirectly through hatred of the nonJewish world, somatization, compulsive work, some outbursts at home, and encouragement of their children to act out their denied aggression. Farents who vere conflicted about aggression often didn't set normal limits for their children (Sigal, Silver, Rakoff \& Ellin, 1973), dian't provide them with reasonable discipline oi constructive channeis for the expression of rorma1 aggression, and often communicated subtle cues for their children to act it out. Thus survivors' children vicariously gratified their parents' wishes (Barocas, 197j; Sigal, Silver, Rakofi \& E113n, 1973; Sigal, 1971; Krystal \& Niederland, 1968). Krystal \& Niederland (1968) succinctly said "The repression of aggression (in Eoncentration Camp survivors) tends to produce problens of aggression in the next generation."

Indeed, the children of survivors have been found to have a great Waeal of conscious and unconscious resentment: 1) at the lvazis and against aankind, 2) for their not having grandparents and relatives, 3) for having been cheeted of nomal parents and a nornal childhood, 4) for feeling different and isolated, 5) for fearing that love will mean potentia] Ioss (Dandelt, 1980), 6) towards parents for (s) using the war as a 
controlling instrument, (b) in some cases never sharirig war experiences with the children, Jetting them devejop thoir own fantastes of survival, (c) providing a role model of a]1 work and no play (and are envious of Anerican born faniliss who ljved a nore relaxed, leisurely, and happy 1ife), (d) placing such a high expectation on the children and not accepting then for nto they really are, (e) not understaniing them, (f) not being enotionaliy available (Kinslar, ig8I), (g) bejing easily irritable anci for (h) beirg overly derencient, (i) rot ailowing them to express their con pain, (j) the use of violence on the part of some paretis, ard Einaly for (k) souetimes rot proriding them with consistent Jewish role nodels and a Jewish education.

\section{Innovation (Creativity)}

In sivaying the professional and avocitionel pursuits of children of survivors, the possibility arose that a grorp of highly talented; gifted and crétive people was being investigated. Tndeed, the survivor parentis thensulves, in order to survive and adjust both to the camps and then to new Jives in new niares, likely developed sone unusual strengths and gifts that later infuenced their chiliren. It is therefore worthwhile assessing creativity in this very special group.

\section{Sgciel Activisu}

Jucy Steintz in a speech at the First International Conference on Children of the folocaut Survivore, stressed that survivors' children $+x$ as a grour have a mul broader sense of social responsibility than is Lsuajy found in people of their age and economit backround. Because they bote the brunt of social injustice, they are able, clained Hs. 
Steinitz, to respond to other socially depriver groups. Ir the light of these statenents, it becones inperative to evaluate social activism in the children of survivors.

N. Sex RoJe ICentity.

Sexual identity may be an issue for survivors' children (especially males). Bacause of the male survivor's experiences during the war (which have been interpreted as bejr: more damaging to men than to women), and because of his slowness in aljusting to his new country and achieving psychological recovery, he had difficulty in establisiring his traditional role as hear of the family. In a typical survivor fanily, tre husband took a subsidiary posjtion in the emotional and interpersonal life of the farily, As a result, boys could only identify with a weak and in-erfectual father, while the nother was tive 'strong' and effertive parent. This created ajficulites in establjshing a viable icentity for the nale child (Trussman, 1968). According to Trossman, if either parent was severely debilitsted by the Concentration Camp syndrone and did not fully participate in homelife, there were difficulties in store for the survivor's cirild in the splate of identity fonation this was especialiy so, irosman teels, when the erotionally absent parent was of the same $s(\cdot):$

The evjone citer above cones mainiy from aescriptive, methodologically gientonble stucies, and shows us only that children of survivors may exibit salient personality characteristics. A concertad effort was hede in this study to exanje each of the variables objectively under conditions of soljt methodology and carefully concejved experinental design. íron resentroh res used as a poinz of departure from which to 
Expiore, In an unbiased manner, yaxious notions that had already acquired the status of facts; although they had yet to be proven. 


\section{REVIEW OF THE LITEEATUPE}

The reviev of the literature falls into six broad categories: the effect of the trauma of the Concentration Camp experience on the survivors; the nature of adolescence and the susceptibility of adolescents to Holocaust trauma; the inter-genarational transmission of trauma; investigations of survivor families and children; the psychopathology/normality of the survivor child and notions of his/her uniqueness; and the methodology of earlier studies.

Most of the existing studies and inquiries on survivors and their chileren are strongly psychodynamic and clinjcal in orientation. Since this researcher's basic outlook is psychoanalytic in nature, the psychodynamic theories and interpretations offered in the literature are not criticized in this review. At the end of the review of the Jiterature, however, a critique of the methodology of previous investigations is offered. The present research, which examines "normal" orildren of survivors, is criy the fourtin study attempted on a non-clinical. pcpula-tion. Furthermore, the methodology of the present investigation is nore rigorous than that of provious researeh stucies.

Q THE EFEECI OF THE TRAUM OF THE COHCENTRATION CAMP EXPERIENCE OW IIHE SURVIVORS

Acute psychic trauma, as experienced by the individual can be understcoo as some overwhelring experience in reajity that results in shock and djerganization within the Individual's psyche (Krysta1, 197x). Traina overwiens che psyche, Ais a result, the individuaj's behavior 
and thought processes tend to regress to more primitive levels (Klein, 1974). The effect of trauma is also determined by a) the quantitative and quaj.itative stimuli overwhelming the stimulus barrier of the individual, b) the resulting dynamic changes and disarrangements of the psyche with which the individual finds himself or herself unable to cope, rather than by the external situation itself (Klein, 1974). In what is termed "ordinary traune", or "acute shock trauma" (Niederland, 1971), there is usualiy a sudden single traumatic experience which destroys the defenses against "excitation". On the other hand, oppression of the Holocanst is a long series of traumatic experiences aimed not only against the life and physical integrity of the individual, but also likely to impair most essential and fundamental psychological, biological and social functions. They are thus 1ikely to snake the emotional basis of the individual's existence (Klein, 1974). In these cases the organism may develop a raised stinulus barrier (a protectjve shield against traumatization) without which the individual could not continue to exist. Rlejn hypothesfzes that changes of the sort nentioned could, with the return of peacetime conditions become permanent acquisitions of personality: Klein feels that the Holocaust, because of its nature, structure and prolonged frth duration, was particularly traumatic to anyone exposed to it (K1ein, 1974). The repeated brutai and sadistic trauna inflicted on the Holocaust victims, which produce similar efiects in individuals of diffexent personality structures (Chodoff, 1966), are characterized by a) a prolonged state of total heln.lessness, b) constant pervasive threats and reality of torture and death, c) chronic starvation in conjunction with forced labor, d) total degradation to the point of dehumanization, e) recurrent terror equsoles, selections In which one's own survival often depended 
on a family member or another co-prisoner being killed, f) total or almost total family loss, loss of society, reference group, occupational status, possessions, language and rights, g) the necessity to maintain absolute control and the suppression of any aggressive or altruistic reaction, h) explicit denial of causality, i) the immersion in and confrontacion with death in its rost ghastly and grotesque forms as a factor of daily experience, j) assaulis on and impaiment of identity with changes of self-image: self estrangement. Changes of the body inage vere effected by requiring that the inmates be fully shaved, dressed in priscner's garb and depriving them of everything human iricluding their nanes. Whese changes of body and self image led to severe identity problens, k) The above picture was accompanied by regression to primitive forms of functioning with some identification with the aggressor (Chodoff, 1.966). This cumlative survivor experience usually leaves a permenent: psychologica? rark in subjects exposed to such massive traumatization (Niederland, 1968, 1971). Irautman (1971) agrees that Concentration Camp traumatization had 1astirg after-effects as does Meer]o (in Krysta1, 1968), Bychowski (in Krysta1, 1968) and Chodoft (1966). Jaffe (in Winnik, 1957) concluded that a biopsychic, irreversibie a]teration of the whole pursonalty rakes place which is caused by the inpact of chronic smatic ario psychic traumatiration. This suggests a pathologically altered constitution with newly acquired tendencies to neurotic reacticns and behajor. Gubel (in Winnik, 1967) also comments on the sylorome's irrevexsibility as does Winnik (1.967) who feels that probonged txatua niay iead to severe jmparment of the fundamental biopeychology or the victim. This thay, he says, sonetimes resilt in proexestive disorat:; with may resist any treatment ... "the regenerative 
capacity of the human psycle uay be severciy impaired." Nathan et al. (1954) also comment on the syndrome's chrcnic character.

Krystal (1971) feels that Concentration Camp traumatization has caused the survivors to develop a chronic disturbance of affect, i.e., they tend to orewreact physiclogically to anxiety and depression. They . manifest "affect regression" in shich affect is manifested in an undifferentiated, prevertai way -- in a sonatic fashion, with increase in some psychosomatic syrptoms.

Peisonality changes in the Concentration Camp survivors due to prolonged tratimatization are relatel to quantitative factors says W. NiederIand (1968) who exanined hundreis of camp survivors. Maseive traunatic experiences of this sort have devastating effects on the psyche. Most survivors suffer from chronic or recurrent depressive reactions, of in accompanied by states of arixiety, phobic fears, nighinares, sonatization (as a sigter of chionic stress, anxiety and rage), and broodjog muminam tions about the fast and lost love objects. The sequelse of massive end repeatei traumatizacion (which are not wecessarily distinct entities and way overlap) are I) anxiety, often assoctated with phobic or hypochondriacal fears, alone or in combination, 2) disturiances of cognition anc metrory, 3) chronlc depressive reactons chanoteataed by guit (about thaix cur survival when others were destroyed), seclusion, isoIation, lack of affect (emotional constriction), ard apathy, 4) psychosonatic symptons or disorders, 5) psychosis-like or psychotic manifestations, 6) lifelong sense of helghtened rulnexability to and increased awareness of barigerous situations, 7) disturhances of sense of identity, body-ingse, and sel-image, 8) permanent gersonalicy changes, or radical dasurtion in maturtion, especially those who were imprisoned at ar. 
early age. The personalfty characteristics associated with these changes are: masochisn (with or without concomnitant clinical features of depression is the nost common after-effect of persecution), passive-aggressive personality, inhibition of sexual initiative and potency, inhibition of intellectual functioning, memory and outside interests, problems of identification with the aggressor, self-hatred, inability to trust others, disturbance in object-relations (inability to express affection, spontardeicy, and awareness of emotional investment for fear of loss of love objects). This clinical picture became known as the Surviror Syndrome (Nieder1anu, 1971, 1968; Niederland \& Krystal, 1968; Chodoff, 1966; Jaffe (in Winnik, 1967); Winnik, 1967). Tuteur (1966) also gives a eeneral description of the syndrome, as does Nathan (1964). Nathan (1964) insists that the Holocaust survjvors nanifest an idiosyncratic sydrome, not amenable to classification according to the accepted psychiatric nosological entitiss. Eitinger (1971, 1963) generally describes the Concentration Camp Syndrome as do other researchers, but he poses an organic etiology for it (starvation, head trama, severity of torture). Ha feels; that it was only nhysical tratmatization in Concentration Canp treatuent that was responsible for the Concentration Camp Syndrome. Choluff (1966) Egrees with some of Eitinger's points. Trautman (1971) describes the syidrore in a similar fasticn, and calls it the Traumatic Anxicty Syndroma. This synrirone is associated with orief reactions, psychosomatic conphaints, naladaptive behavior reactions and perscnelity probitus in practica? life and in social interactions.

kystal and Niederlanc (1960) include "chronic reactive aggression" as a post-trana symptom. They feel that since it was necessary to repress the ageressict during the parecution, the survivors act as though 
they had to deal with ar inordirate mount of aggression subsequent to their liberation. problems oc aggression art also related to the mechanism of Identification with the aggressor, and an inability to undo this identification. Awareness of this idantification may add to the survivor's enormous burder of unconscious guilt. Krysta and Niederland note that this problem is handied in many ways: i) affect lameness -suppression of all affect, 2) turning the aggression against the self, Which potentiates the tendency to depression already caused by survivor guilt ... survivor gujit being aribivalence and repressed aggrossior 2ajinst the lost parents for abandoning their children, 3) soratization, 4) Ioss of ability to enjoy life, 5) generil blocking of all aftects, and 5) projection. Bychowhi (1968) reminds us that Concentration Centp survivors were unable to acconplish the work of mourning. The repressed aggression conard the lost oijgat prevents the comietion of nowning. Nide in the self-raproach of nany yourgar patients blo are conentrafion Camp survivors js their repressea rage against the now murdered perentes wiso tailed to protect them fron the persecutions to which they were subjected. As a resuit the survivors stil1 iendin emotionaily attached to the lost iove bjects (minc bad dod at Nari. herds), and their lives are experierced as empty and ionely. The envivors apper to be constantly giteving and zeeling desolate. They yearn for a reunion with their carly lost love objects (mother, father, siblings).

Klein (1972) in his sturies of Israeli survivors in kibbutzijn descrited a sinilar symarome (though not so severe bevause of the anelioratirg effects of libhut: life in particular, and participation in Israeli culture in generai).

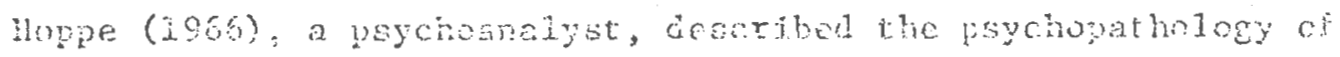




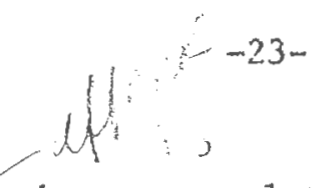

the survivor syrdrome in inore analytic terms. 1) A 1ack of basic trust, a hopelessness and holplessness, apathy, and a feeling of time standing still, 2) regression to infantile behavior, 3) fjxation upon early identifications, itealization of one's childhood and lost family, 4) severe guilt feelings against which one defends with avoidence, denial, Iepression and regression, 5) deep-rcoted disturbsnces of boly image (deper-sonaljzation, sonatization), 6) djeturbances in the develupment of the superego througit destruction of the ego-ideal and a fixation upon a nusocinistic-subissive attitude. Here aggression is turned against the self, with resuiting depression, or is focused on the outside world, with a "hate acidiction". T) Frequentiy, failure to ariapt to a new country or cuiture.

In order to investigate late effects of Concentration Camp traumatiantion, Dor--Shav, in 1978, examined "rormal" Concentration Camp sir-vivors who had never requested psychiatric help. She experimentally conf jrmed the faci that these sumpors generan]y had rore inpoverished and constrobed persmalitjes then those who escaped internert. They also hed more difficklty in social relationships and tended to maintain detachent Fron others. In addition, Dor-s!hav foun that the Concen-. twation Camp survivors' perceptral-cogntive functioning was less compiex and mole joox]y difterentioted than rot-survivors. 
THE NATURE OF ADOLESCENCE AND THE SUSCEDTIDILITY

OE ADOLESCENTS TO FOLCCAUST TRALMA

What were the effects of Concentration Canp living on the development of those individuals who were entering or who were already in adolescence at the tirae of their experiences? It is apparent that the Concentration Camp life complicated an already difficult, vulnerable and complex phase of development.

Adolescence is a period in which regressive behavior makes its appearance. This regression is in the service of progression to a mature, we1l-integrated adulthood. The goal of adolescence is to achieve "identity", a stable sense of self. It is an achievement of

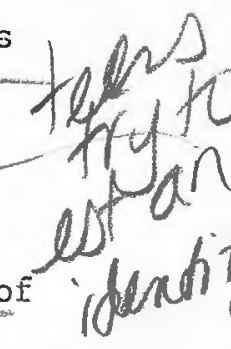
self-awareness in which the individual accepts his/ner inner complexity and ${ }^{2}$ able to relate this individuality to others. The adolescent quietly experiments in iiving until he/she attains his/her goal of selfhood.

Wher adolescence begins the youngster finds his/her self-estetm under relentless attack. He/she suddenly finòs himself/herself experiencing strange and disconcerting changes in his/her body (and his/her body image), a sudden increase of forbiduen aggressive ard sexuil impulses, and a need to aevaiue (and separate from) his/her parencs, thertey losing a valued part of hinself/herself. His/tuer usual. rasponse to these experiences is yaguc anxiety and a sense of inner 1nss. At this point the adolescent is hurgry for new relationships to help relieve him/her from these disturbing feelings. He/she needs people to identify with (to help him/her formulate his/her identity) and his/her relationsinips to others is usually determined by his/her ow needs.

In order to achieve autchomy and a clear sense of identity, the adoIescent needs to relinquish his/her parents and many aspects of his/her 
childhood se]f. In a sense, desth and mourning are an immediate part of the adolescent experience.

Other intense feelings that the adolescent is suffering from axe 1) guilt inspired by a superergo that is feeling overinvolvenent by aggressive and sexual impulses, 2) the need to loosen dependent and erotic lies to parents in order to prepare for indepondence and mature love, 3) the absence of a real sense of idantity and tire anxiety of the struggle to deternine a sense of self.

Adolescence then is the period when final individuation takes place. A re- evaluation of the self ocsurs, in the light of new physi-cal. Fowers and sensations. The psyche of the youngster is in constant flux, and continual restructuring takes place. Infantile conflicts are settled (or not, resulting in permarent symptoms or charaater disorders), and the foundation for enduring, personality cbaracteristics is formed. Adalescence is often a beneficial period, when the aiolescent has an opportunity to rectify and morify negative chiliahood experienes through new identifications. In additjon, an ego ideal is formed (friends, superjors). The ego ideal is a controliting agent, similar to the superego, but not pritnitive. It gives life meaning and a new direction. It is also able to regulata selfmesteen. The ego jideal also jnfluences heterosenul object choice (Blos, 1962; Freud, 1949; Freud. 1958; Heeks, 1971. Furinan, 1973).

Krystal (1971) implies that ajolescent survivors were more profomdly affected by Concentration Caip traunatiation than were adult survivors. Ye tell.s is that adolescent survivors had a much higher rate of psychosomatic disease than adult survivors (vulnerability to somatization is greater in adolescence). Wystal feels that the high rate of psychosmatic disease in individuals tranatized in their adolescence is relaned to the interference in the develupnert and rogression of 
affect expression, with a conssponding deverbalization ard resomatizaEion. The psychosonatic diseases deveiop tratead of enotion. Krystal concludes that adolescent survivors' rate of affective disturbance is very bigh in relation to advit survivors ( $40 \% \mathrm{vs} .20 \%$ ), as is anxiety $(75 \%$ vs. $26 \%)$. The effects of traumatiagtion in acolesccnce is to foster a fear of affects, says kryota1, and to cause an arrest in their evolution into the mature type.

In 3.964 , Koeniz examined 25 individuas who hat beer subjected to persecition in ghetros and Concentration Camps during their adolescance. Roeilig refers to Eriksou's theory on identity crises, and especialiy on acute identity diffucion at the end of adolescence. Tu his discussion of aciolesefnt survivors of the Holocanst, Knenig pestulated that nost characteristic of the personality of adolescent Concentration Camp sur. vivore is chronic identity diffusion beyond adolescence (an extension of Frikson's concept). Pecauce the victims vereforced to witness extrente brutalities, their traditional principles were shattered. Morals once considered desirabie and good were declared invaidid by the Nawis. The upheaval, djosolution of the family and eradication of their homes Anstroyed any chance for these jouths to identify with the value systems of their parente. These youths did not have an opporturity to estabijsh an judependent joentity (ohich would ordinarijy be esteblished at the enci of adolescence). They ail stinl carry on an almost desperate forced attempt to aitain identifications for thenseives throtgh thejr children. Hoppe (197I) says that based on Exikson's concept, he finds that aroiesceats in Concentration Camps were blockec in their identity formetion. Wu to the enforced regression and loss of basic trust, a disfusion of time persective may casse in turn a continuous identity dif-- 
fusion.

The probler of identity and trie quest to give up the parents, according to Kestenberg (1982), are the most important adolescent tasks. When the adclescents' parents were degraded and killed by the Nazis, the adolescent identified with the aggressor. The characteristic adolescent regression can combine with the repression during persecution to make their respective influences unclear and to "hinder the process of adolescent recrganization of the ego and stperego."

Edith Sterba (1968) wrote on the effect of persecutions on adolescents. She was a consultant for the placement of youngsters after World War II. She examined and studied 25 cases betiveen the ages of 12 and 20. She fourd the following: 1) the yourgsters continually felt like strangers or outsiders, 2) they continually expected or demanded more than they goi or were enijtled to, 3) whey spoke about their pasts with utter honclessness and denvession, 4) meny children had symptoms of insonia, rastlessness, nemausness, storachaches, neadaches, corstant fatigue, and feelings of general weakness. They were frequentiy so depressed that they refused to get help for their symptoms. 5) 'Ihey had vast prohiens concerning separation and synbiotic needs, 6) these young people vere hypersenitive, rostless, aggressje, and difficult to nandie. Sterba these figs trawarizations may have had on the acioscert phase of development. She feels that omotional maturity had been made impossible for them.

Danto (1966) and Fink (1968) mertion that one of the most important jobs to be perfomed by the cindd in edoleszence is to master his or her Oedipal confliats, weanwile breaking ties with his ocdipal and pre- 
Dedipal objects. They wonder how this could have been accomplished in the carps in the light of the adolescent's furced regression to analretentive levels of dealing with his/her separation from his/her parents. The carp stress forced a regression frot the Dedipal level of development to an anal-ietentive and sadistic ore, and this process of separation from 'objects' (parents, sitlings) took place at a time when they were actually gruesomely and inhumanely exterminated. The only 'new' objects the adclescent could identify with were the sadistic-aggressor Nazis. The overall result was an inlibition or arrest of further development of the cgo towards autonory and the achievenent of an independent identity. Danto and Fink assume that the damage to the psyche tended to be permanent.

In $1968 \mathrm{Krystal}$ and Niedsrland wrote that the repressed aggressive impulses reartive to the persecution, made the nomal evolution, maturation and mastery of death wish derjvatives in adolescents, impossible. In view of the wholesale destruction, it became too threataning to discover their own destructive irges, especially towards their parents, because of the dreal of the onnipotent powex of those urges. Thus, mucl of the syngtomotolcey oi the surviror can be traced to the maladaptive landing of aggression.

In a similar viu, Danto said, "Of prone frocriance is the need of the atolescent to ded with his ambivalent feelings ad conflicts." Anbivalent fantasies and feelings frequently involve whiderous wishes. The resolution and successul repression of such conflicts is materiaily adod by tise fact that the objects of guch fecjings are living and present, and this offers a necessary reassurance as well as a basis for reality testing. Adclescent survivors did not have the presence of 
theit parents for zeassurance agajnst the fears of their destructive wishes. This resulted in enormous feelings of guili.

Expressing similar concerns as Frystal. and Niederland, and Fink and Danto, Dr. V. Bental (in Winik, 1967) uses cininical case observations to make her point. "Both patients vere still in their pubertal process when they cane to the Camp, where they lost their families. At this stage of development the Dedipal striving, togethor with the ambivalence conflict, awaken again. rhe experiences of the Camp regressed them to the sado-masochistic stage, and by the dreadiul fulfillment of the death wishes towards the parents, the feeling of guilt becane so overwhelming that there wes ro way out of this conflict." H. Klejn (1974) concurs. Hoppe (1971) reports that Pani and Herberg examined 49 survivors of persecution who ware born between 1923 and 1.943. The former adoiescent inates of Concentration Camps suffer from especialiy severe and permanent psyciotraumatic disorders.

The loss of love and rejection by the predominant sccial group vas particularly jetrimental to adolescent survivors, wrote kestenberg (1972). They were exiled and pubiicly degrader. The sclf-inage of the aciolescents sufered greatly and seif-hatred wris generated.

Paul Chodof (1966) roparte that one fartor accounting for dif-ferences in the type of sympions is the age of the victim when he/she was under Nazi influence. Young people (sirvivors) have nanifested, princijally, uroxichal gialdevelunent and chracter reformazion. Suvivors aged 20 to 30 duming the war have chiefly marifested anxiety states; in

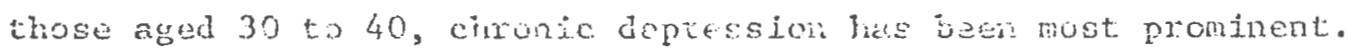

Billel Klein (1971) took pains to connut his sudies on the fani-

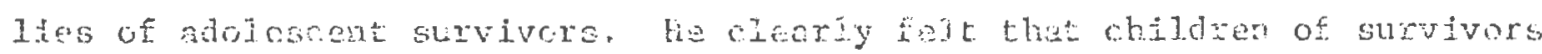


who were adolescents during the Holocaust was the group whose study demancled the most attention. In 1974 he reentioned that the adolescent survivor often went througn emotional crises "with depressive fcatures, suicidal thoughts and psychosomatic symptoms, experiencing repetitive dreams of deati and death situations." .

Hoppe (I962), in discussing psychological damage due to the Holocaust, intentionally chose three adolescent patients as representative of the survivor group.

Kesteriderg (19i2) emphajize; that of the varicides that are of importance in the survivors' childrearing practices, developmertal level of the victin when the trauna tock place is vital. Barag (in Winnik, 1967), in speaking of adolescent survivors, said that their developint was epparently arrested during their years of internment, where they spent the years in a sort of continuous dreamstate. Their reality testing renained deficient.

The personality changes that took place as a result of massive traumatization, writes Niederland (1968), show a radicaj djsruption of the entire naturational developnent, bohavior, and outlook, especially in parients who were taken into Concentration Camps in early life (but not entirely lacking in adults subjecter to the stress of prolonged persecution). At a talk given at the first Irtermational Conference on Children of Holocaust Burvivore in Toverber, 1979, Eitinger stated that in Czech studies, those survivors who were persecuted as children were more anxious, variabje, tired and depressed. Those persecuted as children had moze pathology than those persecuted as aults. In 1973, Extinger himele wrote that it was the yougest survivors who developed most intense aniety aftar the camp traunatization. Danieli (1980) 
stresses the need to know the age of the survivor during the Holocaust, whice Hoppe (1971) xentions thet H. Stzauss reported a "Iisturbance in the growing up process in survivors who were incarcerated at the age of 5 to 15 years." Robinson (1979) Firds a sigrificant correlation between the age of the individuai at the beginning of $\mathrm{Nazi}$ persecution and psychological danage, which was much more serious in the very young. Fustin (1980) wites that adolescent survivors hai to deal with a different kind of sirvivor guilt than adult survivors. The younger survivors had lost parents, grandparents and siblings - they didn't have spouses or children killed. "Their enocional investments were in the prinary nuclear family, which may have exacerbated feelings of abandonment and anxiety. Because of relatively early sejaration fron their perents they may have more (than adult survivors) of a tendency to suffer from emotional inpoverishrent and may find it more difficut to identify themselves with the parental role."

Bychowski (1968) insisted that it is quite important for as to realize that the effects of massive eraumatization depends to a large ertent on the age at which the individual becaine affected by the persecution. It is significant theit the most defply affected may be the person who was subjected to the Molosaust when he/she vas a child. Winnik (1967) agrees with the majox inpcrance attributed to the age when persecutions weve experienced, as does por Shav (1978) and Hertz (in Winnik, 1967) who points out that the age of the experience of trauna determines the fate of basic eto developnent.

The dabaxate traumatiation of a young person by an authority is temed "soul murder" by shenguld. This results in a person, accoing to shergold, nido is robbed of tis identity and of the ability to nain- 
tain authentic fecings. Fink (M68) states: "the unique immersity of the concentration canp experience during the developmental phase of adolescence is responsible for an emotional illness which cannot be completely understood within the conventional framework of the aetiology of traumatic neuroses .... It is my conviction that enctional illness cannot (in this case) be explained primarily as the result of unresolved, unconscious infantile coriflicts."

Chodoff (1980) concludes that adolescent concentration camp survivors were subject to 'severe and basic' deprivations in development. Their formative years were spent under Nazi rule which was characterized by losses, brutality, interference with nurtiring, companionship, educatjon and an immersion in an etmosphere of fear and suspicion. He feels that early years endured in this mamal would often result in maladaptive vays of living so completely bound into the fabric of personalty, that future favorable life experience -- even psychotherapy -.. would have limited positive effects.

Although it seens clear fyom the above discussjon that those parental interactions which wexe ordained to be most gisturbed vere those involving parents wio were exposea to the Concentration Comp trauma as adolescencs, we must also rementer the edolescents' surprising resilLence, pliability and capactity for adapting to changing circumstances. Thoughten! speculation as to how these characieristics influenced his/her adjustneit both to the Holocaust traune and subseguent parenting is In ordex. 
THE INEEX-GENERATIONAL TRANGRESSIOA OT TRAUNA

The nature of the parent-child interaction presumes the transmission of personality characteristics from one generation to the next. Barocas (1975) Eentions that the process by which the irauma of the Concentration Camps is transinited to children of survivors is highly complex and needs 'considerable clinical exploration'. Herzog (1982) asks "How does what the parents endured or escaped make its way into the child's mind? Are the modes of transmission conscious and intendad, or do they occur through the unoniwious chantel? Cari a general model for trie transidssion of tratima be constructed?" only within the last few years have researchews and theorists begun to tackle the mectanism of transmission in a serious manner. Although the notion of transnission of trama had energed thenty years ago, most thinkers eanoed thoughs simijar to Haller's (1982) that "although further study is escential, transmission of the meaning of the nolo-. cause across genarations is too complex a phenomenou ever to be fully comprehended." The fact that the transinission of trama ard personality characteristics did indeed occur was siggested as eariy as 1966 by Tuteur (1966) who deslared "only the future can tell about the emom tionl developmeni of children who have matured under tha image of a parent who had fecad death fo: several years and then show the unavoidabie psyctiatric ramifications."

Sachs and Titievsky (1967) offered an article illustrating the transmission of personality characteristics caused by trauna. The authors described a mother who used the cefense mechanisms of identification with the aggressor to master ansifty. Sha used it when hiding from the Nazis in the wocks, identifyng with her ivaj perse- 


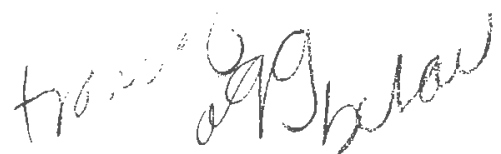

cutors, and later in aggressive behavior toward her son. As a result, Her son became overtly aggressive. In addition, he turned some of the zggression back on himself (in masochistic behavicx). We see that this defense mechanism is now found in two generations. It appears that the mother's originai identification with the Nazi regire is "handed down" to the son. The boy, though born in the United States Long after the Nari terrors have come to an end, j.s suffering from the Nazi persecution in the forms of first mother-induced, then self-induced, aggression. This process, when continued, could result in handing down of group aggression to many succeeding generations.

Trossman (1968) frankly stated, "Nazi death camps scarred not only $\Varangle$ the survivors, but also sma of the next generation."

Brojy (1973) described how even mijd traume to the parent can be transmitsed to the second generation, and Newilan (1979) noted that some children who were horn after 1945 recapitulize their paranta' symptoms and wenave like survivors tor. They may incorporate theix: parents' sulvivor gujilt ari deef share as thuir own.

Kre11 (1979) was the finst to attempt to offer an explication, however vague, of the process of transussion. He contends that o. child of survivors is open to a fahric of irleas and emotions both voiced and unvojced, that afiects a1.1. the major thenes of life; "the precionsness and precariousness of existance; the rejevance or irfors relevance of material goods; separations and deatli: grief and mourning; religicn and icientity." He writes that no child of survivors can be exempied from the influence of the rolocaust. Disguised and hidden aliustons ere frenuently mace by sirvivor parents to "the odds arainst then surviyjng the death earps and haveng childron." Eventually, the 
offspring experiences his/hex life the sane way, because by all odds neither he/she nor the parent were supposed to exist. The comprehension of that facilitates the feeling of being a survivor in the child. Ganpel (1982) writes "All childrer. (ce survivors) act out a scenario of which they have no knowleage, a scenario that is not theirs but, in fact, belongs to the history of their families and especialiy of those. that have survived the Holocaust."

Bergmann and Jucovy (1982) try giving sume explanations for the transmission of Holocaust trauna, but their interpretations also remain somewhat nebulous. They say that some survivors transfer the trauma of the Holocaust to their children simply because "they continue to live in its shadow." Other survivors constantly compare and contrast their living children with those who died in the Holocaust, forcing these 'replacenents' to live almost two lives; one' in the present and one in the past in identification with the dead children. Another group of survivors "unçonsciously equates the child with the persecutor, "while yet another cluster asks their chilaren to act as parents to then, often because their own parents disappointed then and were unable to guard them froli victinizatior. The althors conclude that survivors have perhaps "transformed the Holocaust into a personel Inyth, and transmit the myth to thejr children.". In survivor families in which parents have not spoken about their Holocaust experiences, children tend to create these myths based on their fantasies of their parents' experiences.

Kjnsler (1981) quotes Richard Rabkin's inore specific notions about Holocaust transmission. He thinks that "pain and evil as social processes" are transmitted "when the opportunity for full mourning is un- 
avallable." According to Rabkin, the "infiziction of suffering from one victim to another (survivor parent to his/her child) provides relief rather than ramorse." Rabkin feels that if pain and suffering are inparted from one generation to the next, survival mechanisms such as healthy skepticism, ambition and zeal are also transmitted.

Grubrich-Simitis (1981) attempts to provide a theory for the transmission of the effects of trauma. She says that the massive traumatization of the survivors effected the second generation in the form of a "cumulative trauma." She insists that the young child requires its mother to protect him/her from too much inner or outer excitation, and to be empathic with him/her in a flexible manner. Although there wexe. no gross violations in maternal caretaking, the survivor parent was frequently emotionally unavailatile and there were intexvals when enpathy was lacking. Over an extended period of tine, frequent periods of lack of empathy have a traugatic effect. The survivor's child, Grubrich-simitis hypothesizes, in order to comnunicate on an emoriona] level with his/her mothex, tried empathizing (and identifying) with her

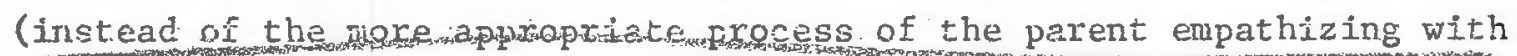
her child). This strained the child both physically and erotionally and this is what consituted the traume in the child of survivors and resulteỏ ir distorted enot:orolal development.

Kestenber: (1982) developed her theory for the transission of parental trauna fron her psychoanalyses of Holocaust sirvivors and their children. In on introduction to hex theory, Keztenberg nutes that parents pass down to theix children what their cwi pareats have done to then. Cirildxen a1so aie influencel by their parents re-enactment of traumatic experiences that occurred to then when tiey were 
young. She also says that ro matter what age they were. whon they were traumatized, survivor parents "introduce into their parenthood" not only the usual identifications with living or deceased parents and siblings, but also various people who were part of their persecution experience. "Through the extension of the usual types of identification to include perpetrators and victins, they recreate the atmosphere of the Holocaust in. their homes."

Kestenberg (1982) presents her theory for the cross-generational transmissicr of the effects of trauma in a clear and thoughtful fashion. She suggests that as the child's developirent proceeds from stage to stage, a parent regresses with the child in an adaptive manner. Via this regression the parent is better able to understand the child, and can help him/her resolve the issues of a particular phase. The parent usually progrësses akead of the child and guicies the way toward solving the problems of that phase. Analyses of children of survivors reveal that survivor parents piaced the major responsibility or the child to advance fror a pliase that was paricillariy meaningful to the parents with regard to thejr Holocaust experiences. The parental behavior wis not merely momal parentel regression; it dreh the child into the trat-matic world of the Holocaust. Childien, therefore, according to the particular concerns and tasks of each derelopmental stage, "were especially receptive to the transmission of the main traunas in their parencs' history of persecution; more specifically, to the distorting, pathogeric influence of the parental attitudes resulting from these traumas" (Grabich, 1931). For exenpite, Holocaust thenes that concerned themsalves with body-functioning hegan to be transinitted at. birth, and persisted. Dhher ouvival themes, for instince, revealed 
therselves in the feeding concerns of the oral phase (a mother whose principal trauma during the Holocaust was the danger of starvation might have envisioned feeding her child as a life and death issue and conweyed this notion to it); while still others evidenced themselves during the anal phase or the oedipal phase (identifying with parents either as victim or persecutor) or in latsncy (a father who was convinced that he survived only by hj.s endurance for hara labor may have transmitted to his child during latency that only work is life preserving and reacted with abzormal worry when the child fuund the developrental transition froin play to work difficult (Grubrich, 1981)). Not all Holocaust themes are present in each survivor child -- yet, Kestenberg says, there seers to be a sort of survival coinpiex that is transmitted to all offspring of survivors. She feels that most, if not all, developmental phases are tinged with survival. issues. Kestenberg goes on to wonder whether this 'survival complex' js as universal as the Oedipus complex, and is. as is the Oedipus complex, a source of both adaptation and psychopathol:ogy. She poses the idea that this complex may be latent in most individuals, and is activated oniy under corditions of disaster.

Herzog (1982) has been studying early family development, and how "raretaker corflict and content" is transuitted to children at the Clinic for the Development of. Young Children and Farents at the Children's Hospital in Bostun. He has developed some thoughts on crossgenerational transmission in general, and cross-generational transmission anong Holocaust survivors and their children, in particular. He feels that the issues of greatest potential ilisturbance to the yourg child are those that. "cannot be contajned in the adult-ajult interaction batween the parents, and tinat thus overflow onto the ahild. The 
parental protective envelope that optimally functions to shield the developing child from potentially hamful influences and intrapsychic and extcrnal forces is forged by a parentogenic alliance between the spouses, designed to provide a safe space for the optimal development of their chila or childret. This safe space permits not only titration, expression and containment of libidinal and aggressive impulses and their derivatives, whose direct application might prove deleterious and over-stimulating to a child, but also a mouming and restitutive place where prior ard current mortifications, hurts and discontents can be healed and handled." If the parents' conflicts, problems and strong feelings are not "hela" within the parentogenic alliance, they will be commicated anci crangmitted to the child.

Herzog raises some questions concerning post-Holocaust marriages and the resultant parenting. He wonders whether survivoss were abje to provide circumstances favorable to the areation of a safe space in which both the horrors of the past and the needs of the present could be shared. He asis whether suzvivors were abje to construct marital relationships that fostered 'therepeutic understanding'. He is curious as to whether survivors (if narried to other survivors) were able to en-dure each other's grief, pain, etc.? He comes to some conclusions: 1) It appears that lst marriages of survivors -- marriages that were unencumbered by exterminated spouses and childien -- could more easily mairtain a safe space in which the trauma they lived through could be shared and metabolized and onjy minimaliy impinged on their childrers' developinent. 2) Survivor-fathers (husbands) seemed to be more impaired in the ability to set up safe apaces than were survivor-nothers (wives). Gender difference with regard to the suvivou parents seemed to disappear 
when both parents were survivors. The wuan's capacity for closeness frequentiy encouraged her to help hex husband coustruct their safe space. Herzog's experience rith survivor parents lends strong evidence to the notion that there was a range, perhaps a normal distribution, of the ability of survivor parents to create a safe space within their relationships. "The norc constricted the siared safe space between the parents, the less the opportunity for healing and containment of the parental trama withir ihe zelationsijp and the more the child (or children) of survivors was asked to serve as a special kind of selfobjert whose job was to share, undo, amel.jorate and restitute." (Herzog, 1982). If the parental trauma is not metabolized and integrated and remains unoound and attended by powerful emotion, it is inevitable that the thoughts and feelings associated with it will overflow onto the childran. The overflow will express itself maximally in the area of caretaking. "The very act of caretaking, as weil as the affective climate, then become the medium for the message." Caretaking berame then, the vehicle for the transmission of trama. Herpos ends his paper by saying "Without intervention, a relatively stable chain of transuission can occur. We are seeing inot only survivors' chitgren but also their graidchildren in whon therc are mantifestations of wich a legacy." 
INVESTIGATIONS OF SURVIVOR FARIIIES ANO CHILDREN

About eighteen years ago, studies began appearing on the incidence of disturbance amorg children of Holocaust survivors. The survivors' children ware now becoming adolescents and young adults and appeared to te "overrepresented" it psjchiatric treatment (Trossman, 1968). Questions regarding the effects of trauma on the second generation began to be asked.

Judith Kestenberg (1972) reported on the results of a questionaire circulated to 320 members of the American Association for Child Psychoanalysis. The questionnaire was aimed at compiling information about the analysis of chjidren of survivors. Particular questions of importance were: 1) do the children of survivors share common emotional difficulties?, 2) are survivor parents' holocaust experiences transmitted to the second generation?, 3) if they are, how do they influence children of survivors? Kesterbexg disclosed that at 1east 20 analyses of children of survivors have beeri conducted, with meny more psychotherapies and consultations. Becaune of the personal difficulties they had in Iistening to Corcentration Camp stories, many anelysts themselves showed some resistance to examing the relationship betreen their patiento' pioblens and tie survivos parents' axperiences.

On the basis of her preliminary data, Kestenterg arrived at tha conclusion that there are nany uriables afjesting the survivor parent that are relevand in considering possible effects on childrearing. It Is inportant, for example, to assess the exient of psychological damage to the patient in relation to his/hor age, type and duration of persecution, tramatizaticn, and pre- and post-Holocaust experiences. It is therefore of grent importance to understanc and dorine the terms "survivar's 
child" and "survivor parents". Kestenterg suggests that the term "survivor's child" applies to an individual, not necessarily a child, whe was born after the Holocaust, and, while not himself/herself subject to persecution, is the child of at least one parent who was subject to persecution.

Her definition of "survivor parent" is more complex. She includes people who survived the Nazi Holocaust in either Concentration Camps, ghettoes, or through difficult hiding, and who, as a result, share some psychological characteristics relevant to raising children (Wanderman, 1976).

The issue of the definition of the word "survivor" merits attention and Irequently has not received the consideration it deserves. This is an appropriate point at which to address this question. Kestenberg (1972) aigues for a broad definition that would even include refugees and their chjidren. Somenberg (1974) also defires a "survivor" in a more general way as a "person who lost his property, his homeland, was branded a sinner (Eor being Jewish), was rejected by his social group and condemed to die." Robinson (1979), in Jerusalem, examined the psychological adjustment of hospitalized children and adolescent survivors of the Holocaust, and found no differences between the psychopathologies of those who were in Concentration Camps and those who were in hjing. One possible conciusion to be reached iroir this finding, is that both survivor parenis who were in hiding and those who were in Concentration Camps suffered similar traura. Robinson, thus, has marroved his lefinition of "stirvivor parents" to those whe rexe either survivors of the camps or survivors who hid out during the Hoiocaist. Krei. (1979) prefers a mote strimgent definition of "surivor". He 
defines: a "survivor fanily" as one in which "one ar both parents survived a Concentration Camp." He feels that chese families are uniqua, and can't be compared with other survivors and their families. He seys that survivors who were fighting as partisans didn't necessarily suffer degradation, separation from families or starvation. Those in hiding were not at forced labor and were in touch with the outside world and had access to information. Those in hiding or those who were partisans therefore retained a greater level of self-respect and dignity and were not starved, humiliated and tortured like those in Concentration Camps. For the purposes of this investigation a "survivor" is defined as an individual who survived the incarceration in a Concentration Camp during the Holocaust for a period of six months or more. The persecutions in the camps with their resulting enduring trauna were fundanentally different from any other sort of persecutions during the Holocaust. The effects of the Cuncentration Camps were uniforiniy more consistently. brutal, horrific and traumatic than the effects and torments of any other uniform experience during the Holccaust (experiences of loss, cultural isolation, etc.). According to Kestenberg, a.11 survivor parents have experienced extrelie rejention and denigtation by their envịonment, frequently resulting in feelings of self-hatred. This repudiation and derogation may have beer especindy detrimental to adolescents and may have affected their roles as perents of adolescents. If this self-hatred is not somehow countered by greater self-esteen, survivor parents may present themselvas to their children as "iorth1ess", (and expect their children to redeem their degraded identity through special deeds). The exposure to taibarous realities (concentration camps, Nazis) and incomplete mourning for important lost objects, in- 
stitutions, and a past self (as he/sine was before the Holocaust) may also interfere with ceriain functions necessary for appropriate child rearing. When survivor parents witnessed the degradation of their own parents (Kestenberg, 2982) they lost faith in then and transferred their belief in 'parental mipotence' onto the Nazis wro they put into the role of vengeful, punishing parents. The shift from identification witr parents to identification with persecutors was aided by defensive jdentification with the aggressor. Both identifications with their parents and with their persecutors became part of the identity of survivor parents. Children of these survivors were then often treated as though they were incarnations of the Nazi oppressors. The result was often the survivors' hate of their children and an estrangement from them. Counterbalancing this often was the child's and parent's yearning for reconciliation.

In an observational study, Trossinan (1968) reports on the psychopathology of adolescent children of survivors treated at the McGill Student Mental Health Clinic: He indicates that in families wite at least one parent exhibjts even a mild form of the survivor syndrone, unfavorable effects on the child are to be expected. Trossman describez the prevalent characteristics of the parent-child interaction, and the possibie effect of these on the child. The survivor parents oppear extrenely overprotective and in response, whe chiddren becone either sonewhat phohic or rebel. Trossman also surmises that tire parents' relatirg of lolocaust memorjes may be related to depressive sympionatology in theit dhiditen.

Surviror pareats usually expect thejer chilnten to display an ozientation of bestile viginande toward the surroudjig vorld, mech 
like their onn. When the child realizes the irrationality of this ettitude as vell as the suffering ard pain that protpted it, conflict develops. Another parental attitude which Trossman describes is the anticipation that children give meaning to their parents' empty lives. They compensate for lost objects, goals, and ideals, and justify the suffering that the parents have endured. Thus, the child is invested with excessive meanings and expectations and is not treated as an Individuaj. but as a symbol of all the parents lack in their pwn lires and hope to secure through the child. Such expectations, of course, can't be fulfilled, and nany of the children either nake repetitive, fruitless attempts or rebel and give up (Wanderman, 1976).

Barccas and Barocas (1973) discuss their elinical observitions of adolescent children of survivors in psychotherapy. They refer to similar probleris and patterns of interaction within the farilies of survivo:s as Troesman. They dite kenig (1964) and hypothecate that survivot perants "corry on ajmost despezate, forced ettempts to obtain their con identifications through their chjodren." The varents look upon their children as extensions of themselves and use then to eatisfy their own conscious or unconscious neods. In this way pareris may undermine atonomous growth. Barocas and rarocas postulate that bince survivors have much diffic:lty in handing their own agchessive in.. pulses, they may unconscicusly facilitate the expression of agrression in their children. This is perhaps relater to reports of uncontrolled aggresuien erupting in adolescent children of survivors. The authors believe that severe depression in children of survivors restilts from the internalization of angex originally supported by the parents. They also conjecture that the survivars' repeated confiontaitors with death 
during the Holocaust are communicated to children in the form of excessive overprotectiveness and paranoid fears regarding most activities. Finally, the authors discuse the place of survivor guilt in raising children. They h'pothesize that the survivors attempt to assuage their feelings of guilt and explain questions of self-worth (i.e., why did I survive, while others died) by becoming overidentified with their children. The offspring of survivors must carry tine additional burden of making up for their parents' sence of worthlessness so that the survivor can say "I am worthy of having lived." As a result, these children often show unusually adverse reactions to even trivial setbacks and fajlures. Such failures or frustrations in accomplishment in part indicate that the child is not fulfilling the task of confirming the parents' sense of worth (Weinderian, 1976).

Sigal, Silver, Rakoff and L1Iin (i973) undertook a comprehensive study. In this research study the authors conpared 25 farilies of survivors to 20 families of controls (i.e., parerts not under Nazi persecution during the Holocaust). A1? were families who had app?ied for psychological hel.p. All parents were J wwish inmigrants from Central. Europe. The survivor group included fanilies in which one or both parents vere susvivors of a Nazi. Concentrution Camp, and/or hat lost their ow parents in a Camp. The controit group parents met neither of these two criteria. The authors hypothesized that children of survivors would differ from controls in the areae of i) impulse control (particularly the control of afgression); and 2) in a sense of anomie and alienation. The study disclesed that children of Holocaust survivors tended to relate a greater sense of anomie and feelings of alienation than did childrer of the control groups. The study also 
revealed that survivor parents rated their adolescent children significantly higher in conduct problems, personality problems, inadequacy, imnaturity, excessiva dependence, limit testing, and poor coping behavior. Thus, survivor parents perceive their adolescent children as being significantly more disturbed than control parents see their chilaren. In the discussion of their results, the authors conjecture that sone of the problems of children of survivors become especially noticeable in adolescence. Many of their enotional difficulties were taken by the authors to be a result of parentai. preoccupation (with continual mourning for lost family and with various illnesses, both physical and psychological that have plagued them since the war). Already burdened resources nake it very difficult for these parents to provide adequate and appropizate feedback to their children, or to accept their normal activity or normal need for control. The children, as a result, become tense and unranageable, and have particular difficulties in the control of aggression and in identification (Wanderman, 1976). Sigal's et a1. 1973 study, says Solikoff (1.979) was an effort at methodologically sound results, but .... "The biases produced by including only subjects who asked for treatment and by the high rate of refusais to participate (66.3\%); the significant age differences between survivor and control. parents; and the fact that the survivor families were more recent immigrants to Canada than ware the controls, are a few of the metholological flaws in this study and raise serious questions about the neaningfulness of the results." In addition, Solkcff (1979) felt that the measures used were inappropriate and inadequate.

Sigal (1971) characterizes the typical dynamics of the families 
of survivors. He also attenpts to provide us with a theoretical explanation for these dynandes.

He statcs that the parents' relationship to the children is too powerfully influenced by the past, and is not adequately determined by the child's reeds. This is true for a number of reasons: 1) children represent a last hope for renever existence and family survival. They must complete anc develop the potential of the lives of those who died in the ficlncalis. They are vencrated, overvalued and coaxed into naking effocts that may not be related to theix capacjties and talents. AII faults or maladjustments in the child are denied. At the same time, the children are assajled for any departure from parental standards. 2) Parents are so preoccupied with the continuous mourning process that they are unable to respond to the childiren's needs, or react with flexibility. The childwen's denands are seen by the parents as depriving tren of their already restricted and strained affective resources. The parents attack their children for not understanding, for denauding, for not listening. The chidaren usually have difficulty coping with the continuously anxious responses of their parents to their actiona, and eithes go out of control or withdran into fantasy or depression.

Arother factor that influences chjidrein's benaviur, is the senee of guilt aroused in them whin they feel any hostility towards their parents, or rafuse to honor their requests. They then ask themselves, "How can I attack someone who has suffered so much?"

Survivors" children lack jecntity and are depressed. The child who is used as a plaything, to comfort and gratify the overvinelming needs of another person, hed difficulty $i$ asserting his om individu- 
ality.

Sigal feels that it is not the Concentration Camp experienca per se that is pirotal in determining the second generation effects. He speculates that the decisjue elenent is the feeling of great deprivation through loss of inportant figures in the past (the survivor's loss). Sigal declares that children of families of survivors suffer from parental deprivation of a very specific type. He believes that the parental deprivation suffered by children in these families sters from a massive psychic trauma experienced by the parents that has as one of: its conseguences a guilt-ridcen preoccupation with former, irIstrievably 1ost, iove objects.

Slipp (1979) mentions that clinicians who have worked with survivors have frequentiy found that survivors felt that giving of themselves to their children in theit second family meant beirg disicyal to their former dead family. A kind of emotional constricticn and distancing also occurred bscause investing in the new famizy mant to be open anc vulnerable to the trauna of again lcsing loved ones. Klein (19:1), in Israel, undertook a study of survivor famijies who lived in kjbbutz settings. The research was cone with 25 famiites of survivors living in three kibbintzin inhahited mainly by Holocaust survivors. It was conducted from 1967-1969. The parents had been adolescents at the time of the Yolocaut. Open, unstructured interviews were conducted with parents ard childien, and the T.A.T. and the wechsler were adminjetered to Etrst-ubore children (these childien were interviewed by a psycholcgist), and findly poychoandyticaily oriented psychotherapy with a small group (a persons) was corducted to gain deeper insight into the psychodyrath. Klein found that event 
before their birtin, the children of survivor parents were viewed as a source of security and fulfillment, an undoing of extemination, and reestablishment of lost family. Many survivor mothers had fantasies of damage about themselves and their child during preenancy. Some fears of damage continued into the early mother-child relationship. Especialiy during the infancy of the child, both parents seented to be fearful of something happening to it. They were overprotective and tended to i.jentify the first-born children with lost nembers of their original ramiiy. Unconscious as well as conscious fears of separation are apparent in both parents and children. These become more noticeable in danger situations such as war or chjldren's illnesses, when parents compulsively check their children at frequent intervals during the night. Ihe parents have repetitive mightmares of Concentration Caip experiences in wich the children are also present, and are in danger cr. being separated from them. The children clearly also fear separation. Trey spend significantly moce time with their fanilies than the average kibbutz child. overt expression of hostility toward parents is evaded. When confronted with open aggression or danger, these children do not respond in sn active, aggressive manner. Instead, they tend to react passively by escaping, hiding, holding cnto other children, or seeking adult help. With regard to their parents' experiences, crijdrein of survivors tend to emphasize the valorous aspects of the parents' past, nuliffying or: denying the agony. The child sppears to nish to protect the survivor parent -- to take special care of him/her and to avoid asking questions that might hurt hirm/her (Wanderman, 1976).

Solkoff (1980) noted several probiems with klein's research. Kitein does not indicate the sources of many of his conclusions (interviens, 
peychologica: tests), and does not provide uny psychologtcal test data. No systematic comparisons are made between survivors on kibbutzim and those juving in otiner situatiors. Finally, Solkoff felt that the biases introduced by a sole Israeli psychiatrist interviening all subjecte cannot De overlooked.

Russell ( 1974$)$ treated and studied 36 survivor families in a private practice setting in Ontario. These were lower midale-class families in which both parents had been in camps or had undergone "sinilar aire experiences." His clinicaI impressions were the following: 1) survivor mothers felt themselves unable to nurture their children and wanted to be nurtured and helped by their children. 2) Survivor nothers were very overprotective, obviously absorbed with the past, and overwhelmed their children vith tomenting memories. 3) Mothers were the tyrannicai, "stronger" parent, while fathers were "weak", retiring and passive. 4) Cinildren were not encouraged to establish an individual jdertity, but were expected to give meaning to their parents' barren lives anc to replace whet was iost. The parents therefore had exaggerated expectations regarding their children's scholastic achievements. 5) Limits set by the parents were either inflexibie and rigio, or nonexistent. As a result, the children tended to be aggressive, overindulged, and spoiler. 6) The families tended to Jive an isolater life, without comitment to scciety. An aura of depcession, anathy, gloom and emptiness pervaded the fanily atmosphere.

Russell viewed the survivors' children, who were then adolescents, as having sezious sepsration-individuation problems (they had difficulty separating firom treir parents). He wäs aiso cognizant of the constant guilt these adolescents felt at boing angry with thcir parents. Their 
awareness of their parents' suffering made open rebellion nearly inpossibie.

Fogelman and Savran (1979), who have been organizing and leading groups for Holoca'st survivors' childzen, mention the specific problems and issues that have been irougrit up in group sessjons: a) the survivors' children's sense of isolation, b) their negative self-images, c) their lack of a separate identity Irom their parents, d) their difficulties in facing lnss and separation, e) their symptons of cepression, anxiety and guilt, f) their inability to express anger appropriately, g) their mistrustfliness, hj their unresolved feelings towards their parents (especially anger, and guilt feelings resulting from that anger), and i) their conflicts concerning their Jewisil identity. Lisa Newman (1979) mentions similar issues.

Yael Danieli (1980) has ane recent research on children of survivors. Her stidy is based on the approximately 50 stirivors and 200 children of survivors who participated in the "Group Project for Holocaust Survivors and their Children", located in New York City. She isolates characteristics that identify survivors' children as a group. Membership in this group is composed of injividuals who use somatization as an unconscicus cxpression of rage and gijef, and control and manipulate others with it; who are guarded and isolated; who have extremely close contact with their parents, even in aduithood, and have 1fttle sense of independence and autonomy; who have difficulties in decision-tnakjng; who suffer from unmet dependency reeds; who have difficuley in asserting themselves and expressing anger; who lise guilt as a defense (it oprates as a venicle of loyalty to the dead, and keeps the survivors' children engaged in a reiationship with those who 
gerished. It also maintains a sernblance of fanilial continuity.); whose major identity is being a child (of survivors) and who dread being on their ow and beconing aduits (which is equal to being isolated, empty or dead); who are generally wary of hurting others and are keeniy sensitive to cther's' pain and mood changes.

Danieli feels that survivors' chilcren have consciously and unconsciously absorbed their parents' Holocaust experiences into their lives almost en toto. Holocaust parents, in the attempt to give their best, taught their children how to survive. In the process, however, they eransuitted to them the life conditions wrier which they had survived the war.

At the First International Conference of Holocaust Survivors, in early November, 1979, L. Eitinger reported on numerous international studies of survivors' childrer. In general, he has concluded that children of survivors suffer from "severe and special difficulties." Slipp (1979) reports that Shamai Davidson, Director of the Shalvata Hospjtal iñ Tel-Aviv, where a large number of children of survivors have been seen, stated: "ihe trama of the Nazi Concentration Canp is re-experienced in the lives of the children and even the grandchiloret of camp survivors. "The efferis of systematjc dehuanization are being transinted from one generation to the next through severe disturbarices in the parent-cilild relationship."

To data, the research done on chiliren of survivors and their families has concentrated on ciinicul populations. There are a fer studies, however, which have looked at "normal" populations of clilicen and families of holocaust survivors.

In one of the very few fairiy carefully controlled stuides of the 
behavior of chiloren of survivors, Solkoff (1975) reports that Rustin (1971) conpazed 77 Jate adolescent cinidzen of survivors (43 females and 34 males) witt an equal number of similarly marched second and third gereration late adolescent Jews (chese were not cinical populations). "In contrist to previous researcil findings and clinical reports, Rustin found no evidence that effects of traumetic experiences of survivors generated psychopathology in their offspring. No significant differeices energed between the two groups on measures of guj.It and hostility."

One of the most recent studies comparing current psychological functioning in survivors and their children with a 'reasonabjy matched' (Solkofi, 1.982) control group was conducted by Loon, Eutcher, Kleirman, Goldberg and Aluagor (1981). The investigation, an objective persoraifty evaluation, used a normal sample - not based on indjviduals identified as having psychological problems, and the children vere from the sauf families as the participating survivar parents. All of the findings were compared to those obtained with a control group, whose parents enigrated to the United states pricr to the beginning of Worjd ilar II (between 1937 and 1939). (The 24 controi families vere of a injgher socio-economic status than the experjuental group, and most came from Germany -- whereas the place of birth was equaly distributed between Poland ard Cermany for the survivor women, and nore than half. the survivor wen were from roland. Also, the survivor group was older when they came to the U.S.)

The researchiss divided the 47 survivor fani.jies into tro subEroups: 32 wh wion at least ons of the parents was in a Concentration Camp, plise two fenale survivors; and 13 in which at least one parent 
survived in Europe but net in a Concentration Camp. The MMPI was administered to all participants. The adults completed the Parent Version of the Current Iife Functioning Form, an instrument measuring attitudes and behavior constructed for this investigation. It included 21 items evaluating Mental Health Status used in the Midtown Manhattan Study. The children's version of the Currenc Life Functioning Form measured the child's perception of parental attitudes and behavior plus the Midtom Mannattan items. The mean MIPI profiles for both the males and females of all three groups of parants were well within normal limits as were the profiles for the three male and female offspring groups. There were no important differences among the groups (both children and adult) on the mental health rating scores. Although because of the small numbers in cach subgroup, the results of the study may not be regarded as conclusive, this is ore of the few demonstrations based on controlled research, thet survivor parents do not substantially differ in psychological adjustment from the gereral population of Anerican Jews (Solkoff, 1982). The findings of this investigation indicate that Concentration Canp and other survivors of WorId War II and their childrer, as a group, do not: manifest serious psyct:clogical jmpaiment. Leon, et al. clain, on the basis of this study, that it is erroneous to assume that all children of survivors "bear the indelible scars of their parents' experience and therefore exhibit significant psychological disturbances because of the trauna undergone by the parents." They feel that it is a great disservice to children of survivors "to autonaticaily assume that they, as a group, are psychologically inpaired because of their parents' experiences." An arditional. impression that these authors had was that "pervasive survivor 
guilt as an extremely influential psychodyranic factor in Concentration Camp survivors, although not specifically assessed, didn't appear evident in the findings of this study."

The latest, and quite complex study looking at individual and family functioning of children of survivors was done by zlotogorski in 1983. He compared 73 normal functioning offspring of survivors from a uniformly high socio-econonic background to 63 controls who vere of similar: socic-economic status, family size and birth order. The chilIren of the Holocavst survivor group were born after their parents had been repatriated. They were children of Concentration Camp survivors and/or parents who were held captive in a slave labor camp during the period cf June 1940 through May 1945. The control group were "Jewish individuals" who live in major metropolitan areas of the United States (there was no further description of this contrci group). Each member of both groups was administerer the Washington Unirersity Sentence Completion Test (MUSCT), the Satisfaction with Well-Being Questionnaire and the Family Adaptavilily and Collesion Evaluation Scales (FACES). The Satisfaction with Wel1-Being scale reprosented cognitive and affective assessments of a wide range of life areas. The WuSCT was used to ascertain Ievel of ego development. All subjects were rated at either the coufornist, self-aware or conscientious level. Conformists are characterized by superficial niceness, obejience to rules, cmphasis on the need to belong and concexr. with issues of social appearance. Their cognitive style is characterized by conceptual simplicity and stereotyped cliches. Self-aware subjects eviderce a difftrentiation of norms and goals. Theix interpersonal styite is charactexized by awareness of self in relation to the gicup. Conscienticus subjects are characterized 
by their self-evaluative standards, farmilation of long-term goals, and concern for responsibility. They show cuncern for patterns of communication with cthers and are conceptuaily complex. FACES is a self-report scale designed to systematically assess levels of family cohesion and adaptability. Cohesion is defined as "the emotional bonding that ferily members have toward each other and the degree of individual autonomy a person faels in the farily system." The four levels of cohesion range from extremel $\ddot{j}$ high (enmeshed) to moderately high (connected) to moderately low (separatec) to extremely low (disengaged). Family adaptability is defined as "the ability of a marital/ family system to change its power structure, role relationships and relationship rules in response to situations and developmenta1 stress." The four ievelg of adaptability range from extrenely high (chactic) to noderately high (flexible) to moderately low (structured) to extrameiy Jow (rigid). After the administration of all the tests, it was found that there was no significant difference betveen the groups in ego development or in well-being. Ail subjects were then divided into l:igh, average and low functioning groups on the basis of these two critexia measuree (which were significanty correlated with each other). Deviation scores were calaulated for each subject for both the cohesion and aäaptability dimensions.

The analysis of the data indicated that perceptions of family adaptability and cohesion were significantiy related to level of functioning. Holoceust familes did not differ from comparison families on efther the cohesion dimension or the adaptability diriension and deviations fron the optimal. 1eveis (in individual cases) were a function of the offsprings' sanse of well-being and ego development. 
The results of this researci revealed a wide range of fanily structures within Holocaust survivor families and controls. The averase Holccaust surfivor fanj.y was characterized by 'structuredseparateness'. This sort of family functioning represents moderate scores on both fanily cohesion and adaptability. 'Structured separateness' is very unlike the picture that has been previously drawn of the Hollocaust family. This depicticr has included: a high degree of enmeshent, synbiotic dedication, blurring of boundaries, and disturbances in the communication of emotion. The outcome of this study does not support these rotions.

Tine author says:

"The different pattern of results obtained here as compred to previous studies may be attributable to the issue of sampl.ing (the difference in the level of functioning of subjects in this study as compared to subjects in past studies). Until now; most of the studies have focused on Holocausi families who sought therapeutic intervention. The present sample consists of rorual functioning individuals from a uniforinty high socio-econonic background. The resulte, thereforr, of the earlier studies car be seen as a predicted outccme of, for exampie, the significant relatjoriship between levels of functioning and perceptions of family colesion. A clinical sample. which aay be operationally defined as low-level functioning would be expected to have extreme perceptions of funily cohesion (enreshed or disengaged). However 
these extreme percepticns are not a function of

family type as has been generally hypothesized.

Rather, these perceptions are related to the lower

level of ego functioning expected in a patient sample."

In general, the reasuning involved in this paper is circular and the main conclusion that the survivors' famjlies are characterized by 'structured-separateness' appears to be unjustified and contradictory. However, something of a case is made for the notion that family structures and levels of ego development are quite varied among children of normal. Holocaust survivors. The variation within the children of survivors group is as marled, in this study, as the variation within the control group. On the basis of this paper, an argument can be constructed for the heterogeneity of the group of Holocaust survivors and their children as regarde individual personaitity and fanily structure.

It was suggested by Sigal, in 1971, that the effect of trauma on second generation "normal" and "psychiatric" populations wili not dirfer in quality, but in degree. He reported on a limited sample of people who had rot sought psychiatric help, and who were being interviewed as a preliminary to a study or survivors' families. Cnly one survivor family of the inany interviewed appeared to be functioning in a healthy way, with no sign of pathology in the children. The others showed maladjustment to some degree. This may be so, but indications from results of recent stiries on rormal populations support rhe notion that chiluxen of survirors are no different in psychological makeup fron concrö groups. Jhair parerts experience of trauma, these researciners clain, has no general pathogenic eifect on their children. 
In the light of recent research being carried out on children of survivors, it will be interesting to cvaluate the results of the present investigation, also carried out on normally functioning children of survivors. While it is a non-clinical population that is being examined, this study is finely tuning into the subtle differences between two subgrcups of the same "romal" population. Within this sample of individuals are cinjldren of both adult and adolescent survivors who were subjected to massive trauma. It is assumed that the age, or the developmental level of the individual mediates the effect of trauma. Despite recert evidence, this investigator feels that, regardless of the develupmental stage or age of the survivor when he/she experienced trauma, the trauna should show a residual effect in the second generatiou. The effect of the age or the developnental siage may marifest itself as a difference in the magnitude and type of resijual. effect. 
'THE PSYCHOPATHOTOCY 'NORMAIYTY' OE THE SURVIVOR CHILD AND NOTIGNS OF HIS OR HER UNIOUENESS

The issue of the "norinality" of the Holocaust survivors' children, which was alluded to in the previous section, deserves further consideration. Is there a synjrome, comparable to the Survivor Syndrome, that manifests itself in children of survivors and which attests to the basic unifomity of survivor parenting? If these children do not suffer from a full. blown "survivor's" child syndrome" do they still in some way bear the marks of their parents' Holocaust trauma? Are there pathological aspects to their functioning that set them apart from any other group? Axeirod (1980) asks whether in cases of obvious psychopathology: "Would similar psychopathology be found in children whose parents wcre Hiroshjua survivors, political prisoners, victims of child abuse or survivors of naturiz or other disasters? How mich did Judaic history and culture detract from or aid the (survivor) parents of the children in adapting to massive psychic trauma?" Reiated to these questions is the matier of the uniqueness and specialness of the children boen to rulccaust survivors. Are they a psychologically linique group? Can they be considered homogeneous with respect to basic personality chardetevistics, or is every child of a survivor very ruch an individual with fis/her parcicular personality, dissinilar from all other survivor cftispring?

Ts there a "survivor-child syndrone" that afflicts all offspring of Holocaust survivors paralel to the "survivor syndrome"? Orinione appenr to bs divided, with more investigators favoring the notion that the child's "syuchrome" either does not extst, or is attenuated to the point where it becones a "complex" which is only scaetimes in 
evidence. Other researchers who are in the minority still insist that these inherited peracnalicy characteristics and psychopathology that are teried "the survivor syndrome" occur with fuil force in survivor progeny.

Rustin (1980) mentions that since all survivors clearly did not suffer from the "survivor syncirome", it is fallacious to think that al1. survivor children might evidence a comparable syndrome. Danieli (1980) also suggests that it is too simpie to assume that all survivors will manifest the "suivivor syndrome" and that children of survivors will exhibit a 'transmitted-parallel-symptomotology'. She feels that the responses to Holccaust and pust-Holccauct experiences are variej and heteiogenecus -- "too much so for quick categorization or easy generalizatjon."

Ilse Grubrich Simitis (1981) writes that from hex ciinical experience there dceis not eppoar to be a ciear-cut "sumivor's child syndrome", and that clinical patterns seer in the second generation are quite diverse. She says that wile "the earlier expectation of a thorough going parallel betwen the psychic disturbances in the first and second generation has not been confimed, certain sinilarities in symptoms, fantasies and defensive structure based on the children's identifucation with their paients are nevertheiess discernible." Peflectively, Kestenberg (1932) statos that while there is general agreement that a definitive survivor's child syndrome has not emerged, there appears to be a similarity "both in content and in netapsychological seature $"$ that gocs begond the individuality and unfverselity of thenes in the anulyses of survivor's chiddren. For exanple, the issue of hov the parent survived becones a centrai 
theme in the analyses of survivors' children. Another motif is the precccupation with the lio?ocaust experiences of the parents such as starvation, loss of family and specifics of persecution. Instead of a survivor child's syndrome, Kestenberg feels that mental health professionals traating children of survivors may be noting a "complex or constellation of features which differ in quantity and inportance from patient to patient. To call it a syndrome rather than a "compiex" would iraply a pathology that is not always in evidence." Kestenberg goes on to say that many of the features of this "complex" are not pathological and some are even demonstrations of strength and adap. tability. Kestenberg varns that her thoughts about survivor's children are based or analytic evidence, and should not be generalized to include alI survivor's offspring.

Porter (19\$1) feels tinct there are ilot enough data to assert with certainty, but that it is extremely unlikely that a pathological synarome exists, He thinks, however, that a mill (as compared to sur-vivor parents) guilt syndrone may appear jn some cases. Thj.s "guilt syndrome", according to Porter, is worthy of study and evaluation, but Porter lelieves that it is essertially benign.

(in the other hand, Barocas and Barocas (1979, 1980) emphatically state that children of survivors show symptoms that would de expected if they actually ilved tirough the Holocalst. They say "The children seen in our practice present a picture of impaired object reiatjons, low self-estefn, negative idertity formation and considerable perscnality constriction. They also exhibit increased vinerability in stress ituations, pathological cegression and some tomporary blurriag of ego bundarifs rben confonted with expariences raminiscent oi the 
Holocaust." Although KinsleI (is81) is awate of the achievements and general adequacy of a great many survivor offspring, she notes that when psychopatholosy is present in children of survivore it frequently resembles that of survivor parents. She enumerates the psychopathological features and then says: "Although these symptoms alone are not. unusus1, it is the intensity and frequency with which they appear that seens to form an identifiable and rezognizable complex."

Do all children of survivors manifest some sort of psychopathological functioning due to their parents perhaps idiosyncratic methods of childrearing? The majority of writers in this area of study of children of survivors feel that there is as much adaptive behavior in this group as in any other group. Porter (1981) writes, "Researchers in the past too often emphasized severe pathology not only of the first generation, but the second generation of survivors as well.... I do not believe that a pathology exists." Rustin (1980) asserts, "Despite the trauma of the Holocaust, many of the second generation of survivors do not reflect extraordinary psychopathology, and nanifest adaptine coping behaviors."

In his position at the Clinic of Bellevue Hospital, Samuel Sipp (1979) had the opportunity to notice that there existed a group of children of Holocaust survivors (young adults) who seened to suffer from enotional disorders tharacterized by depression, conflict in emancipating themselves from their parents, guilt, and being selfdefeating in their behavior. In contrast to this group, he became aware of a number cf children of survivors who were functioning at a good to superior level, and were socially adjusted, growing in their careers and developing fanilies. Slipp then conducted a pilot 
study to attempt to discover which Eactors contributed to the "intergenerational transmission of psychopathology." He was interested in knowing what sort of parental behavior distinguished these two groups. Slipp's results suggested that the parents of the first group imparted to their children a negative view of the world, a distrust of others and a continual anticipation of catastrophe. The children in this group, - in addition to those characteristics already mentioned, felt responsible for their parents' emotional distress and had ambivalent attitudes towards success. The parents of the second group, the higher functioning one, communicated their camp experiences openly, fostered an open and confrontative approach to life, pressed less for achievement and rewarded their childrens' successes. According to Slipp, the combination of a negative world view and the denial and avoidance of unpleasant realicies, in addition to greater pressure and less gratjfiration for achievement seemed to contribute to the emotionsl difficulties in the first, less functional group. Therefore, not all survivor's children, according to Slipp, have psychological. difficuIties. Much depends on the emotional environment of the home. Axelrod, et al. (1980) reported findings similar to Slipp's. These researchers ware engaged in à ongoing study of hospitalized children of. Holocaust. survivors. They found that "one major difference betweer functional children of survivors (some are on hospital staff) and their hospitalized patients seemed to be that their families, far from being sccial isolases, were involved in survivor organizations and the children, while growing up, were exposed to fairly open discuesions of parents' curp expariences in 'ion-frightening' vays." Agriin, the existence of psjchopathoiogy is not an across the board 
phenomenon, according to Axejrod, et aj., but is dependent on the psychological atmosphere of the individual survivor hone.

Bergmann and Jucovy (1982) insist that some psychopathology unst exist as a resuit of being an offspring of a survivor. They say: "So far as our own experience goes, it is not possible for a child to grow up without becoming scarred in a world where the Holocaust is the dominant psychic reality. With few exceptions, the mental. health of children of survivors is in jeopardy..."

When psychopathology does occur, are its manifestations unique to children of survivors? Rosenoerger (1973), after working in the Child Guidance Clinic at Shalvata Hospital in Tel Aviv, Israel and after aralyzing two adolescunt children of survivors, is convinced that children of survivors "show no distinctive psychopathology," and that differences between them siunld be imputed to the unique parenting behevior of the survivors -- which is mainly influenced by their parsicular perscna!ities. Disazreeing with this point of view is Jaufer (1973) who emphasized, in a case presentation, the 'special areas of vulnerability' that were characteristic of children of survivors.

Are chiliren of survivors honogencous as a group? This cuery has stimulated thought among many investigators of Holocaust phenonita. Almosi ail researchers answer 'no' to this question. Most observers have focused on the heterogeneity of the surviors as a group and their conseguently dissimilar childrearing practices. A great variety of survivor parents each with different parenting techriques and behaviors vili necessarily produce a diverse group of offspring.

Solkofe (1932) in speakind about the survivors themselves, argues 
that they are not and should not be corisidered a homogeneous group (as does Sigal, 1973). Ha feels that important differences in variables such as the age when incarcerated, length of imprisonment, type of camp in which incarcerated, intensity and types of stross exposed to, whether brain damage was sustained and post-1iberation experiences (and factors such as education and skills) cannot be overiooked as potential contributors to the degree of trauma experienced. These differences also effect the varying success of survivors' adaptation efforts and the varieties of parenting behaviors. Rustin (1980) aiso insists that survivors and their children are not a homogeneous group but unique individuals. In addition to those variables mentioned by Solkoff which wight. have inflienced childrearing behaviors of the survivors, Rustin says the quality of parenting the survivor child expcrienced also cepended on: if the extent of the patents' loss; 2) the depth of the parents' depressicn, 3) the reiative investment in the cinila by the parents, 4) the level of affective constriction of the parents, 5) the levei of the parents' anxiety, 6) the degree of the parents' overprcteciveness, and 7) the parents ability to separate from the holocaust and reinvest in their new ives and family. Ye goes on to say that, "The survivor's copirg mechanisms varied, their languages were dissinilar, thejr educational backgrounis were dif.ferent; in short, they were anything but homogeneous." He continues, "... no generalization regardinf the survivor and his rymily is a safe generalization ... any theraptitic work being done with the survivor and the Second Generation must start with settirg aside stereotyping and prejudging of the survivor and his chijd."

$$
\text { Ema liman (1973) very powerfully states: }
$$


"Each individual came to the camp with a different personality, and at a different point in his development, each underwent different experiences in the camp, and each has lived under different circumstances since then. The more anyone has worked with people exposed to a camp experience, the more he is aware of these enormous individual differences and the resulting difficulty in making meaningful comparisons. Perhaps the only shared factors are those of having experienced a stressful interference of more or less traumatic proportions and the task of coming to terms with having survived it." The survivors had to integrate their traumatic experiences into the fabric of their 1ives. The process of integration is itself a highly individual one, and affected different survivors' personality functioning in different ways.
"The specific, direct effects on the child of his parents' camp experiences are therefore not only dif- ficult to isolate but may become meaningless unless seen in the context of the farents' and child's indi- vidual personalities and their interactions.... stress the need to study individual cases intersively, avoiding tempting generalizations in order to understand ... the children of survivors."

In a 1974 report of a joint workshop of the American Psychoanalytic Association and the Association of Child Psychoanalysis that took place in Decenber, 1971, Sonnenberg (1974) stressed that the experts cmphasized that "no special difficulty with specific war 
experiences" influenced the maternal behavior of survivor mothers whose children had some emotional disturbance. The ability of these women to be successful mothers was deternined by a combination of factors: by personality development prior to the Holocaust, experiences after the Holocaust as well as war experiences. Sonnenberg's statement encourages us to envisage the miltitude of possible variations in the survivor mothers' maternal attitudes and behavior as a result of all the variables that influence caretaing behavior.

Aleksandrowicz (1973) did an impressionistic study of 25 outwardly "well-adjusted" survivor families. This group, on the basis of interviews and psychological tests, did not appear to be diagnostically different from other families of similar backgrounds (but not exposed to Nazi occupaticn). They were not a homogeneous group marked by a uniform clinical diagnosis.

Russell (1980) meritions that Rakoff (1978) stressed that the liajority of survivors normalized their lives and achieved prosparity and even happiness. Rakoff felt that the children of these 'adjusted.' survivors had become much like other children of first-generation imigrants, "some enjoying dazzling success," but most "at least a decent run of nedocrity." Rakoff is certajnly not describing a homogeneous group.

Is the individual survivor child, then, a person more different from than similar to others in lis cohort?

Somenberg (1974) says that clinical evidence supports the position that "every child of a survivor is unique, and responds to life experiences uniquely." Generalizations do not appear to be justified. Willians (1973) insists that each child of survivors needs to be 
looked at individually. Solnit (1973) also emphasizes the "many different kinds of children of survivors." Pririce (1980), while recognizing the individuality of the offsnring of Holocaust survivors, emphasizes that the Holocaust must have a profcund influence on the identity of a11 children of survivors. He says that the dynamic forces that we know shape the human personality combine with Holocaustimagery (which exist.s as a result of their parents' survivorhood) to forn what he calls a "psycho-historical identity." The result, he goes on to say, is a set of organizing themes and metaphors that define the individual's sense of who he/she is and the nature of his/her relation to the world. Inages from the Holocaust provide the matexial for unconscious fantasy.

Although Kestenberg (19\$2) is aware of the uniqueness of the survivor child, she feels that his/her perenality is strongty influenced by "the stress imposed by being born under the shadow of the Holocaust." There is a bahance, in the survivor cinid, between unusual. ego strength and some pathology. The choice of strength or pathology depends on a number of variabies (that are not discusseri). From the desire to care for parents and proceed in ore's development, symptons such as anorexia, anxiety, pliobias and obsessiens ray develop. On the other hand, from the sane origin cone adaptive solutions, so that the survivor's child may nurture others, be active, creative, join the helping professions and be socialiy conscious. 
METHODOLOGY OE EARLIER STUDIES

The research done so tar on survivors and children of survivors has frequently been criticized as generally being methodologically unscund.

The most thoictigh critique of research methods was written by Solkoff (1979, 1982), while other recent investigators have also commented on the necessity of a more rigorous methodological approach. The focus of many researchers' criticisms has been on the fact that many variables relevant to childrearing practices of survivor parents have rarely been given notice in the 1iterature. (A number of these variables were mentioned in the previous section and the discussion will be somewhat expanded here.) Many of these variables can "produce differences in types and degrees of pathology (in the child) independent of the effects of parental tramatization" (Solkoff, 1979). An awareness of these variabits is essential for the design and replication of experiments.

\section{Factors that Indirectir Infuenced Cijldren of Survivere}

The first group of variabies that needs to be taken into account are those that directiy affected the quality of the adjustment of the survivor to Holocaust and peschoiocaust expericuses anc indirectly affected the children of survivors. As has been suggested, "the degree of parental. Lrauna may be positively correlated with the degree of piychopathology in the ching" (Axelrod, et as., 1980). The followiag variables nediated fareatal trama: 1) placprenar personality

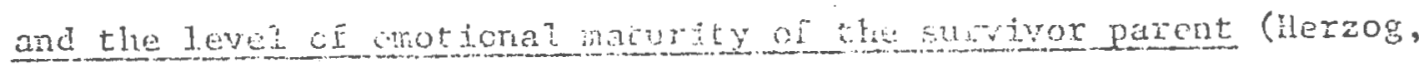


1982; Barocas \& Barocas, 1979; Porter, 1981; Barocas \& Barocas, 1975). 2) Constitutional factors and genetic endownent (Barocas \& Barocas, 1975; Barocas \& Barocas, 1979). 3) The prewar background of the survivor parent (Rustin, 1980; Dorter, 1981). The background of the survivor prior to World War II, says Rustin, is quite relevant to the degree of adjustment macie after the war. The ego strengths and weaknesses of divergent cultural and national groups and the knowledge of history they each brought to the Holocaust experience varied greatly. Different cultural groups varied in education, reifiosity, socio-econonic status, assimiiation and other tactors (Porter, 1981). 4) Age of the survivor parent during incarceration in the camps (Barocas \& Barocas, 1979; GrubrichSimitis, 1981; Prince, 1980; Rustin, 1980; Herzog, 1982; Barocas \& Baxccas, 1975), and the extent of his loss (Axelrod, 1980; Prince, 1980; Herzog, 1982). Rustin writes that the problems for the survivors who were older when interned in the Concentration Camp wera nore complicateo than for those who were younger. In addition to the loss of the prinary nuclear family there was frequently the loss of spouse and children. The survivors trying to compensate for this loss of family overinvested in new childrea. 5) Length of time a survivor parent was imprisoned Prince. 1980; Barocas \& Barocas, 1975; Prince, 1980; Axelrod, et al., 1980). 6) The differences among internment in a slave lebor camp, in a concentration cains or in an extcrmination canp (Rustin, 1980). There were important differences betweer camps and a consequent difference In the treatment of prisoners and the degree of trauma expcrienced by them. 7) The nature of the experiences in the camp. (Barocas \& Barocas, 1975; Axelrod, et aI., 1980; Prince, 1980); the supports available during inprisoment, including the capacity for fantasy; the experiences 
that were actually endured; and the capacity to live a sort of dual existence -- not oniy to exist in the camp, but at the same time to be "grounded" in one's pre-war existence (Herzog, 1982). 8) Whether survivors participated in "Wars of Liberation" may have influenced survivors (and their children) (Porter, 1981). Taking part in either the regular Army, the Worla War II resistance movement or the Israeli wars seems to have had a beneficial effect on survivor families. "The channeling of feelings of powerlessress and worthlessness against a common enemy, either Nazis or Arabs, was beneficial for mental health" (Porter, 1981). 9) Finally, the survivors' post-war experiences were crucial to their adaptation to life in this country and to their functioning as a parent (Rustin, 1980; Barocas \& Barocas, 1979; Barocas \& Barocas, 1975; Porter, 1981; Solkoff, 1979). The shock of the European Liberation to the survivor; his/her displacement from a previous home; his/her time spent in Displaced Persons Camps; his/her trip to the new country; his/her forming of new familjes (Porter, 1981); his/her adjustment to the hardships, language, ilfestyie, and cul.ture of the new country (Rustin, 1980); the degree to which he/she perpetuated preHolocaust forms and values, and the social matrix he/she established for himself/herseif in his adopted country (Prince, 1980); are all vital elements fnfluencing both the survivors' and the second generation's adjustments.

Barocas and Barocas (1975) feel that the post-Holocaust experiences interacting with predisposing strengths ano weaknesses may be responsiblef for some of the features of the final symptomatic picture of Holocaust survivors, and for whether this picture fades or is perpetuated in the children of Concentration Can survivors. They fail to emphasize; however, the effect of the intaraction between all of 
the above voriables, and the central, traumatic holocaust exp on the survivors and their children.

Variables that Divectly Affected Children of Survivors

There are still other variables related to the Holocaust to consider which direct?y affected the child in a survivor family.

1) Axeirod, et al. (1980), Grubrich-Sinitis (1981) and Prince (1980) feel that the degree to rhich family discussions of the Holocaust and of parents' pre-Holocaust lives have been banned and consiciered taboo may infilence the survivor child (and contribute to pathology). 2) The nunerical size of the extended survjuing family may affect the adjustment of the survivor child, says Axelrod et al. (1980). The size may te inversely related to pathology; the sinailer the extenced family the greater the disturbance. 3) Whether one or both parents are suzvirors ray have an effect on the survivor progeny's añatation (Grubrich-Siritis, 1981). 4) The order of birth of the survivor chilaren within a fimily may be an important vartable to ponder. Kinsler (1981) says, "There appears to be additional stress on the first-born or only child born to survivor parents. Later sillings seem to have been less afrected.") Forter (1981) conirms this statenent, but adds; "While the first-born may carry extra hurdens, it nay also be far more ambitious, successful and creative precisely because it has been inbued with special reeds and hopes of the parents. Children born subsequently may suffer legs than the first-iorn, but nay also achieve less." 5) Ainother significant variable: may be when and whore the child was box (porter, 1981). 6) Finaily, the sex of the pacent who is the stirvivor nay be of consequence (Restenberg, 1982). Hestenberg's 
impression is that the image of a rictimized mother is much less threatening than that of a persecuted, helpless father. Mothers appear to be less ashamed of the debasement they experienced than fathers, and may therefore be in less need of being axonerated by their children.

\section{Critigue of Research Studies}

Researchers, especially Sulkoff (1979), have harshly criticized the general methodology of research done on children of survivors. They feel that research designs have been inadequate, and that nethods used are not replicabie and ofter inappropriate. Findings are judgea to have been aneciotal and unsupported. Results are felt to have unnecessarily stigmatized a substantial group of children of survivors on the basis of "generally urreliable data, gathered from biased samples In poorly designed experiments" (Solkoff, 1979). Solkoff (1979) has cxamined the two broad areas of current research: 1) single and multiple case studies and inquiries carried out without appropriate control groups, and 2) experimental studies "in which attenpts were made to constitule control grolips designed to determine thether different kinds of stressful environments would produce distortions in parent-child reiationships that could in turn account for a cammon set of behavior disorders anong the children."

With most studies in the first group, Solkoff found that: 1) It was impossible to generalize the findings to all childrer of Holocaust survivors. Most of this research examined a biased sample of children of survivors who had required psychological help and didn't possess the range of adaptations and coping mechanisins that many children of survivors use (Rustin, 1980; Kuperstein, 1981; Axe1- 
rod et al., 1980;-Prince, 1980; Heller, 1982). In addition, there was a prevailing absence of statistical data that also disallowed generalization. Descriptions tenced to be sketchy and inpressionistic. 2) No control groups were used so that meaningful comparisons cculd not be made with other patients. 3) Psychoanaiytic concepts and theory; without the support of data, were frequently used to justify the various effects of survivor parents on their children. According to Solkoff, the psychoanalytic explanations are little more than speculations. 4) Psychoanalytic studies of survivors are pervaded by psychopathology. This focus on patterns of psychopathology (Heller, 1982; Porter, 1981) deemphasizes adaptive mechanisms of children of survivors, and doesn't consider the possibility that the enotional problems ascribed to children of survivors are "neither as severe, ubiquitous nor uniform as would be precicted by psychoanalytic thenry" (Solkoff, 1979). Being a child of a sur... vivor, says Solkoff, "is not necessarily a significant, predisposing condition for the developnent of psychopathology." In fact "it might be argued that many of these children have become less psychological.1.y vulnerable, more competent. and more creative as a result of their intra-familial experiences."

Solkoff (1979) and others also amply criticize the experimental studies done to date. Sclkoff notes that: 1) The instruments and measures used are often inadequate (there is a relative absence of multiple measuring instruments (Heller, 1982)). Assessment instruments frequently do not have proven validity and reliability. 2) Studies performed until now generally have not been carefully controlled, and cornarison groups have not been appropriate or matched 
on relevant variables. There has been a tendency not to supply vital information about and descriptions of the experimental and control groups. This discourages repiication. 3) Samples have not been carefully selected to represent the populations gbout which generalizations are to be made, nor have confounding biases been avoided. 4) Sample sizes have been too snall (Heller, 1982; Porter, 1981; Kuperstein, 1981). 5) Huge theoretical leaps have been made, regularly, from inadequately gathered data (Solkoff, 1979).

"If we are to draw (useful diagnostic and theraputic) implicatjons from (futire research) for other groups of offspring of chronically trausatized parents, and if we are to develop realistic intervention and prevention prograns, it will be important tc adhere, as clesely as possible, to the canons of good experimental design" (Solkoff, 1979). In addition to correcting the methodological erxors that were enwlierated atowe, Solkorf (1979) foels that a fer additional points mist be made. He is coucenned that by researchers insisting that the Holocaust survivor is unique and different. from all other survivors of rrauma and thair offopting that "this attitude precludes the composition of adequate comparison groups, which are inperative if one is eventually to be able to demonstrate intergenerationai effects of severe psychic stzess."

If $i$ i: is presumed that traumatized parents can adversely affect theix chiliden, Solkoff suggests that careful descriptions of fanily interactions be provided and that both healthy and emotionally upset children within a given farnily be studied.

Finally, Bolkoff (1.979) wams that "Iruvestigations cannut con- 
tinue to wear psycioanalytic theoretical blinders. The relatively low explanatory power of psychoanalytjc theory, with its focus on psychopathology, will have to be complemented with or even replaced by more enpirically grounded behavior theories." 


\section{CIIAETER PI}

\section{SLBJECTS, PROCEDURES, AND REASUREMENT INSTRLRENTS}

\section{A - SUBJECTS}

The subjects in this study comprised a total sample of 64 individuals. The sample was apportioned into four groups of subjects: two experimental and two control groups. There were sixteen individuals in each group, an equal number of males and females. At least one of the parents in al1 groups were former. German jewish nationals, or Jewish Trationals of Nazi-occupied ccuntries. Grolip I (survivor grouy) consisted of children of at least one survivor of the Concentration Camps. The survivor parent(s) was/were an adolescent(s) (between thirteen and eighteen years of age) when he/ she/they entered the Camp between the years 1939 and 1945. Group II (surivor group) also consizted of children of at least one survivor of the Concentration Camps. The parent(s) in question ras/were aiready adult(s) (ninateen years and beyond) when they ertered the Concentration Canp in the period 1939 to 1945. If, in Group I, both parents were Concentration Camp survivors, and one farent was an adult while the other was an adolescent at the time of their internment, the age of the the nother determined whether the subject would be assigned to Group I or not. The parents of subjects in Group II were aII acilts when they entered Concentration Canips. In order to qualify as a member of Group I or Group II, the subjects' survivor parent had to have been subjected to at least six nonths of Concentration Camp internment. A nirimum of six months incarceration was chosen in order to be certain that the strvivcr parent har had signjficant exposure 
to the massive tramatic experience, and to enhance the detection of his/her response to that expexience. The data on the periods of. inprisonment of Group I parents and Group II parents are presented in Table 1. Subjects in these two groups were selected from several sources. 1) A nembership 1ist of a Children of Survivors' Group was obtained from an executive of the organization, and permission was granted to contact individuals on the mailing list. 2) A parents' group affiliated with a New York City Jewisi day school was informed of the project, and a number of parents who were children of liolocaust survivors volunteered to participate in the study. 3) Relatives and friends of subjects and contacts with colleagues and acquaintances provided the remainder of the subjects in these two groups. of the children of survivors who were contacted and net the criteria of the study, $84 \%$ agreed to participate. $100 \%$ of this group completed ail the forms and were interviewed, lhose who declined to participate in the study were either pressed for tine and wera unable to involve themselves in the study because of extensive time comituent necessary, or were doubtful about the use to which the results yould be put.

Group III (control group) consisted of at least one parant who left Europe apprcximately between 1934 and 1941 ; just pricr to the "Final solution". (Many parents in the control groups spent significant amounts of time in other colintries, en route from their homeland.) The parent(s) was/were adolescent(s) (from thirteen to eighteen years of age), between the years 1939 and 1945. Group IV (control group) consisted of children of parent(s) who have the same characteristics as Group I, except that the parent(s) in question was/were already 


\section{Table 1}

Descriptive Information About the Survivor Parents

Subjects' Pareñs

Who were Adolescents

in Concentration Camps
Subjerts' Paients who were Aduits in Concentration Camp

\section{Age Entered Camp (years)}

Range

$13-18$

19-41.

Mean

15.23

24.6

Length of Stay ini Camp (years)
Range
Mean

In D.P. Camps $(\%)^{*}$

57.14

$.67-4.5$

2.24

* The D.P. Camps were organized and run by the United Nations to deal with post-WW II refugees. These camps provided temporary shelter for them. The U.N. supplied legal protection and rehabilitation services (medical and vocational) while the uprooted refugees awaited resettlement. 
adult(s) (nineteen years and beyond) in the period 1939 to 1945.

If in Group III, both parents were emigrants from Europe prior to World War II, and one parent was an adolescent betweer the years 1939 and 1945, while the other parent was an adult during that time period, the age of the mother determined whether the subject would be assigned to Group IJT or not. The inmigrant parents in Group IV were a11 adults between the years 1939 and 1945 .

None of the parents of subjects in either control group was a Concentration Camp survivor. Some of the subjects in the survivor group, however, did have one immigrant parent. The overriding and determining factor as to which group the subject belonged in, in these cases, was the fact that the other parent was a Concentration Camp survivor.

The data comparing control parents and survivor parents are presented in Tatle 2 .

The subiects in the two control groups were solicited Irom a number of scurces. 1) A membership list of the younger inembers of a. Jewish Reformed Congregation in lvev York City was obtained froin the Rabbi of the congragation. After being informed of the gerierai nature of the study, the Rabbi encouraged these menbers to take part. 2) Friends ard relatives of participating subjects and contacts with colleagues, friends and acquaritances were another somce of subjects for the comparison groups. 3) Finally, the parents group associated with the Jewish day school that helped supply experimental subjects provided the remaindex of the control subjects. 


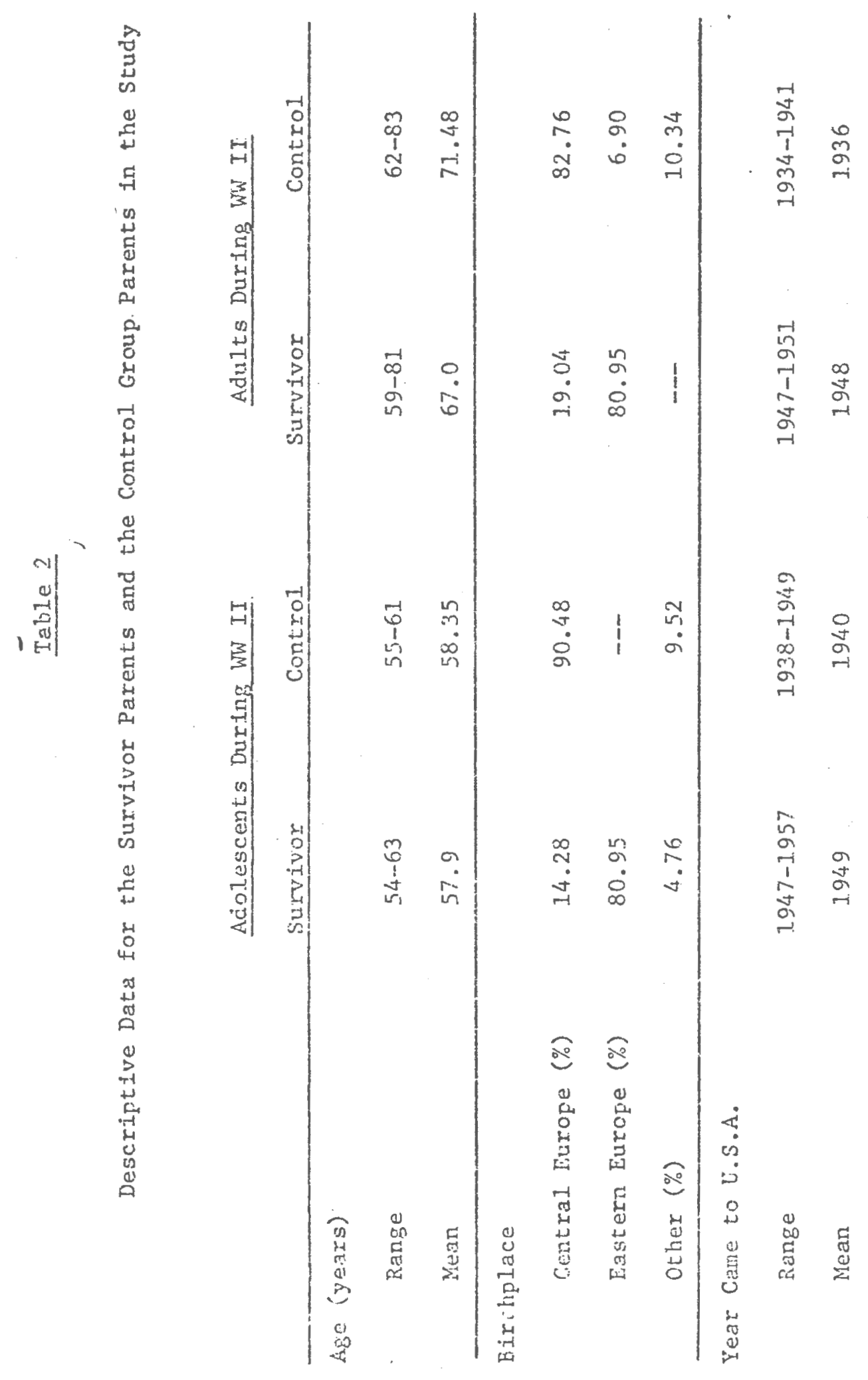


of the potential control subjects who were contacted and met the criteria of the study, $77 \%$ agreed to cooperate. $87.5 \%$ of this group completed all the forms and were interviewed. An additional three more possible control subjects were contacted to replace those who had dropped out, and all three agreed to take part in the study. These three subjects completed all the forms and were interviewed. Those individuals who chose not to participate either after the first contact or after they had received the test materials, stated that their work schedules did not allow for their involvement in so time-consuming a project, or that they did not want to indiscriminately reveal themselves to someone they didn't know. Implicit in several of the refusals was the notion that the study and its conclusions were not pertinent to children of those who had not experienced the Holocaust.

The subjects all shared certain background elements. Their parents vere products of a relatively comon European cultural background, and they all experienced problems of adjustment when they inmigrated to the U.S. The subjects thenstives were all. drawn from large urban areas in the Northeast. Although a nuch graater froportion of the comparison group parents were Cential rather than Eastern European, the match between groups was the closest inat could be made. Most of the Jews who emigrated from Burope prior to the Second vorld Wax were Central European (inainly Geman and Austrian). Even this group of Jews is not easy to locate in significant numbers. Comparison of the experimental group with the predominately Central Europeanorigin control group was better than finy of the alternatives; i.e., comparison with those who have American-Jewish roots or with those 
who have non-Jewish immigramit backgrounds.

The subject selection procedure randomized all the subjects with respect to the following experiential and background factors: the age of the subjects, country of birth, birth order, marital status, education, religious background, location and ervironments of the subjects' parents after immigration to the U.S., other traumatic experiences in the post-war lives of the sibjects' parentg or in the lives of the subjects, existence of extended family of the subjects, and the emotional well-being of the subjects and their psychotherapy experiences. The survivor-child subjects were selected randomly with regard to the presence or absence of a I.P. camp in their parents' background, and whether one or both parents endured a Concentration Camp experience. The characteristics of and the descriptjve data concerning the experImental and comparison groups are presented in Tables 3, 4, 5 and 6. Post-hoc analysis of the data revealed that the background factors of education, income, birth order and parents' country of origin did not. "confound" the study, i.e., effert the outcome of the study. The presence or absence of a D.P. camp in the background of the sur.vivor childrens' parents, and whether one or: both parents were in a Concentraticn Camp, were examined post-hoc as possible confourdirg factors as well. It was discovered that these factors also did not influence the results of the siudy.

Adequately functioning individuals were chosen who were not undergoing any out-of-the-ordinary stress (i.e., death of a loved one, Ioss of a job, etc.) in order to reduce tho possibility that their temporary tinutional siate woulc interfere with measurenen of the 


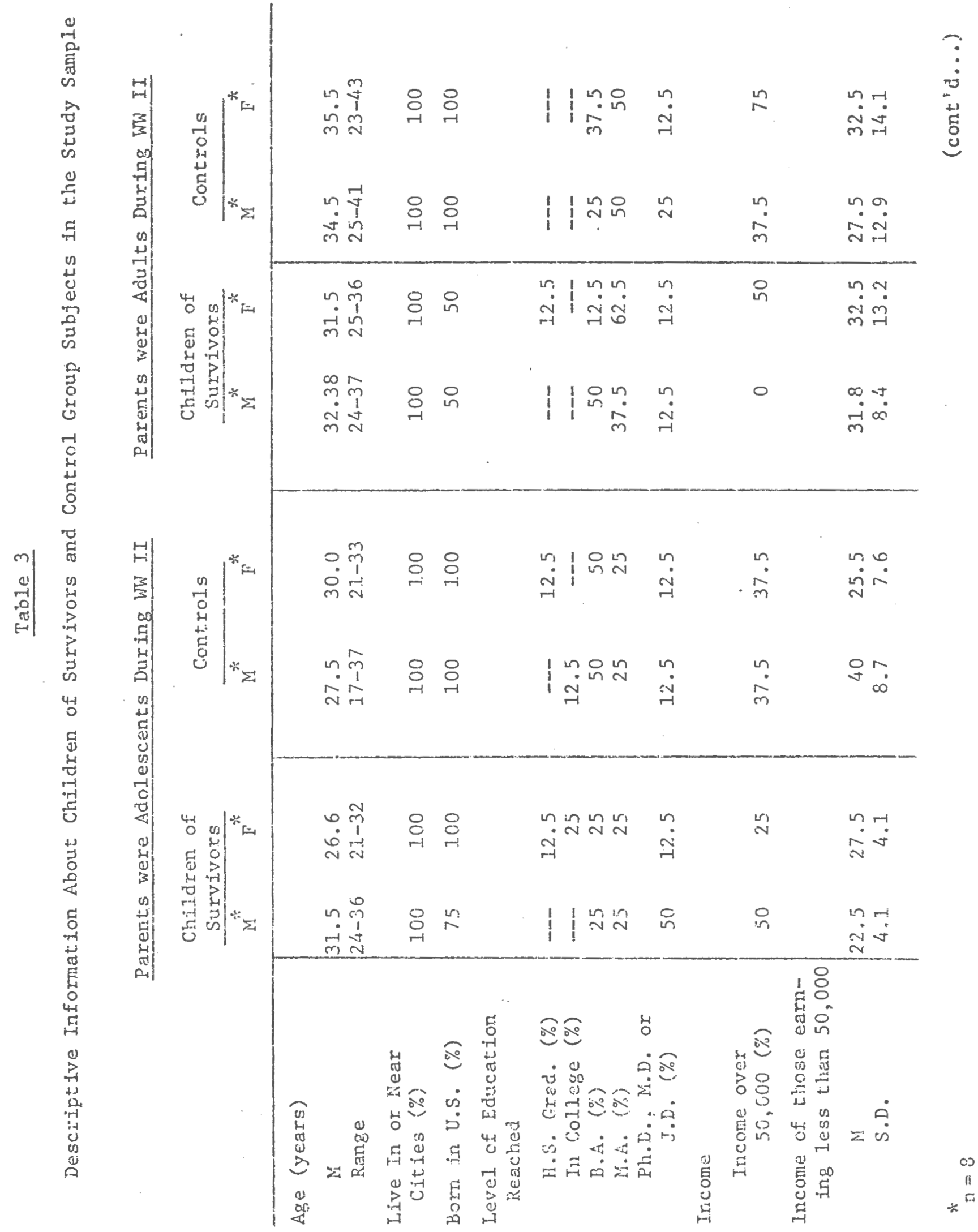




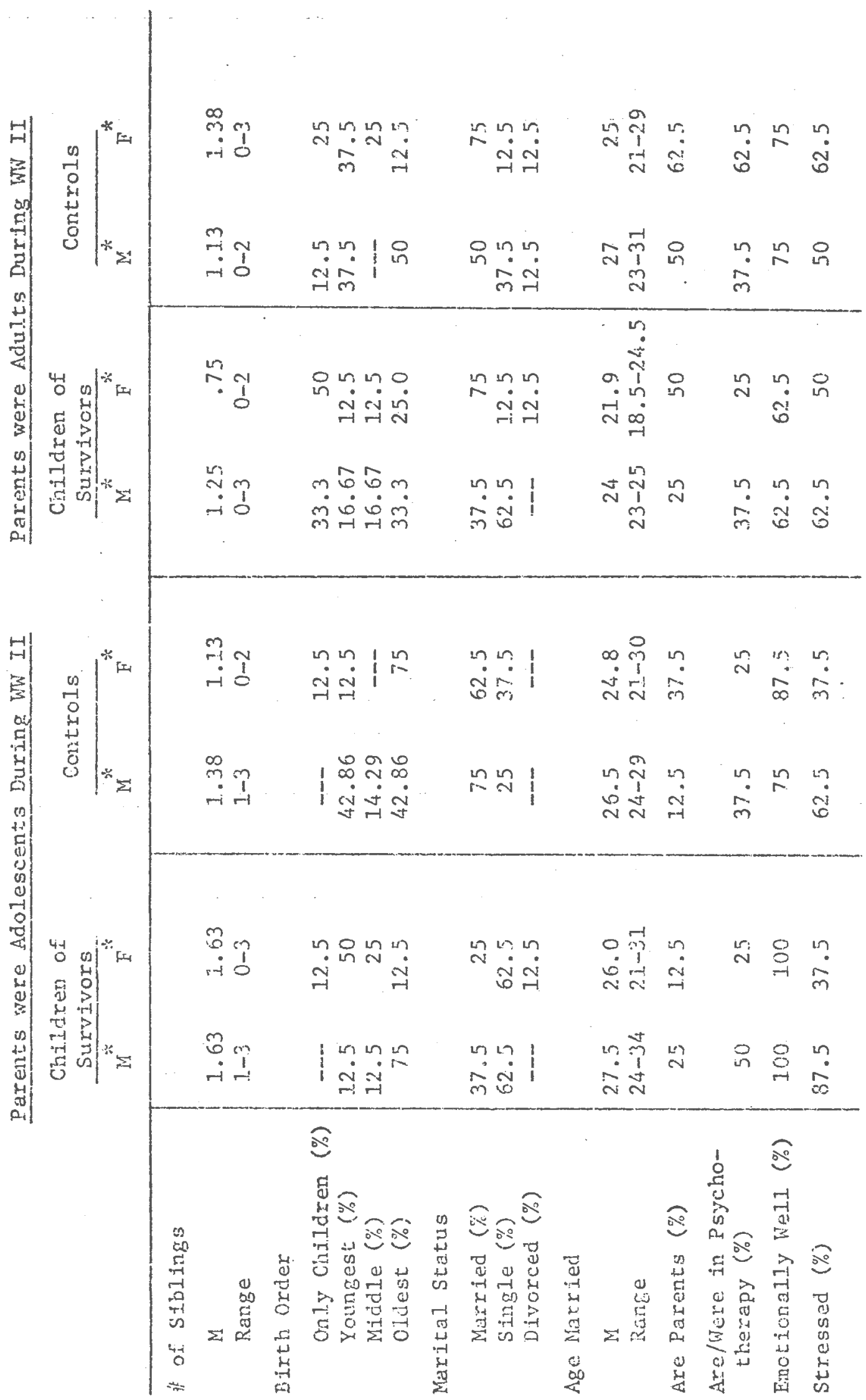


Tal:1: 4

Tescriptive Data for Childran of: Surviyors and Control Group Children Irrespactive of Sex

\section{Childron of: Survivors.}

Parents were Parents were

Aciolescents

in Concentra.tion Camps*
Adults in

Concentration Canps*

\section{Control Group Gildren}

Parents were Iarerts were Adoiescents Adults

During WW II* During WW JI*

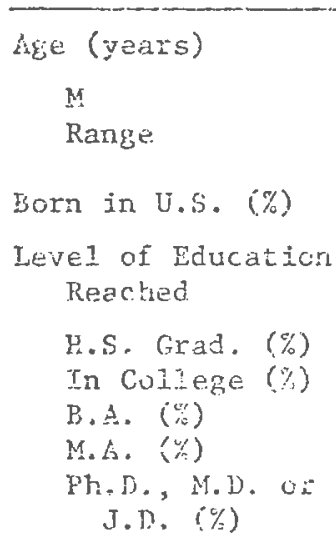

Jncome

lincona over $\$ 50,000(\%)$

Incone of those entning less than $\$ 50,000$ $M$ S.i).

\# of sibiongs M kange

Eirth Oecer only children (o Yourrest $(\%)$ Midalo (\%) oldone (\%)

Marital. Shatub

Marised (\%)

singie (\%)

Divereed (\%)

Age Mrreid

Ni

Ráneg

Axe Parente (\%)

hretrere in

Fsychotrierapy $(z)$

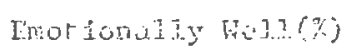

stressed (\%)

$\begin{array}{lc}29.1 & 31.94 \\ 21-36 & 24-37 \\ 87.5 & 50\end{array}$

6.25

6.25

12.5

25

25

31.25

50

31.25

12.5

37.5

25

4.6

31.5

1.0.2

i. 63

$0-3$

1. 0

$0-3$

5.25

31.25

18.75

43.75

42.86

14.29

14.29

23.57

31.25

62.5

6.25

56.25

37.5

6.25

26.86

21. -34

22.5

] 8.75

18. 5-25

37.5

37.5

31.25

3.00

6.5

62.5

56.25
28.75

17-37

100

6.25

6.25

50

25

12.5

$37 . j$

56.25

31.9

10.7

.L. 26

0-3

]. .23

$0-3$

6.67

26.67

6.67

60

18.75

37.5

12.5

31.25

43.75

56.25

62.5

25

12.5

25.29

$21-30$

25,91 .

21-31

25

56.25

31.25

50

81.25

75

50

56.25 
lable 5

Descriptive Data for Children of Survivors and Control Group Irrespective of Sex and Age of Pareut During WW II

Children of Survivors*

\section{Age (years)}

M

Range

Born in U.S.A. (\%)

Level of Education Reached

H.S. Grad. (\%)

In College $(\%)$

B.A. $(\%)$

M.A. (\%)

Ph.D., M.D. or J.D. (\%)

Income

Incone over $\$ 50,000(\%)$

Income of Those Earning Less than $\$ 50,000$

M

S.D.

\# of Siblings

M

Range

Birth Order

Only Children (\%)

Youngest (\%)

Midale $(\%)$

Oldest (\%)

Marital Status

Niarried $(\%)$

Single (\%)

Divorced (\%)

Age Marrjed

$\mathrm{M}$

Kange

Are Parents (\%)

Are/Were in Psychotherapy

$(\%)$

Emotional.1y We.1?

(

stressed (\%)
Contro1 Group Children*

31.88

$17-43$

100

3.13

3.13

40.63

37.5

15.63

46.88

31.25

30.2

10.3

8.7

1.32

$0-3$

1.25

$0-3$

25.56

22.77

16.5 ?

36.15

43.75

50

5.25

12.71

32.09

9.59

45.63

53.13

40.63

6.25

25.6

21-31

40.63

40.63

78.13

53.13 


\section{Table 6}

Distribution of Subjects According to Whether One or Both Parents Were in Concentration Camps

Children of Survivor Parents who were Adolescents in the Concentration Camps*
Children of Survivor Parents who were Adults in the Concentration Camp*
Children whose Mother Only was in a Camp (\%)

Children whose Father only was in a Camp (\%)

Children whose Both Parents were in a Camp (\%) $25.0(n=4)$

$12.5(n=2)$

$62.5(n=10)$ $31.25(n=5)$

$37.5(n=6)$

$3 I .25(n=5)$

${ }_{\mathrm{n}}=1.6$ 
dependert variables. The similarity of the percentages for experimental and controi groups with regard to psychotherapy expertence, emotional well-being and feelings of stress testiry to the apparant sirilar level of adjustment of all the subjects.

Issues surrounding the parenting of cholccaust survivors' children have recently been receiving much attention. Many survivors' childxen, for example, are familiar with Helen Epstein's book Children cf the Holocaust which appeared in 1979. This book and related materials may have alerted the subjects to the personality traits associated with being an offspring of a survivor, and to the special problems confronting them. In fact, $69 \%$ of the survivor progeny in this study admitted to being familiar with the current Iiterature. A post-hoc analysis of the data showed that children of survivors were only marginally more familiar with Holocaust literature than controls $(p<.10)$, and so acquaintance rith the material poses no threat to internal validity. This familiarity, however, may be the source of a threat to external validity, which concerns the generalizability of the study to other setings and populations. Had this study been conducted before the publication of Epstein's book and the consequent dissemination ot information concerning survivors' children, there might be less concern about whether the results can be generalized tc the entire population of ofispring of survivors (and not merely to those who, prior to this study, may have been sensitized to issues concerning children of survivors).

An additional threat to external validity is the hawthorne Effect. This "effect" refers to the subject's tendency to offer a socially desirabje test response. In order to protect thejr parents as well 
as themselves, the experimental subjects in this study might have tried to make a strong conscious attempt to cast theruselves as "normal", despite any possible differences in their upbringing. So as to minimize this effect and to try to prevent this kind of defensive effort to portray normality (to prove with a vengeance how emotionally healthy they are), the subjects' normality and emotional health were emphasized at all stages of the study.

A final statement is required concerning this study's "population validity" (external validity). Since the experimental groups were selected from a large population of children of survivors, the results can be utilized to provide information about and insights into the general population of survivors' children. 


\section{B - PROCEDURE}

The potential subjects were initially contacted by telephone, and given a brief description of the study and its purpose. They vere informed of the approximate time commitment they would have to make, and that there was no payment for participation in the study. No detailed questions concerning the hypotheses and design of the study were answered. Instead, the prospective participants were promised that when the study was completed, they would be given a sumnary of the results. They were also informed that should they want to discontinue participation at any point during the study, they were Eree to do so. The talephone discussion adhered to a standard format as closely as possible.

If the potential subject consented to participate, an interview was arranged for some time during the next several weeks, at a time and location convenient to him/her. The subject was informed that as part of the procedure, the I.ife History questicnnare as well as the Personal Attributes Inventory must be completed. They would be nilailed to him/her and would reach him/her within the next fer days. The subject was requested to complete both measures by the interview date. At the beginning of the interview session, any general questions corcerning the study or the assessment devices; were addressed. Each subject was required to sjgn a consent form (Appendix II and III) indicating his/her understanding of the content and purpose of the investigation.

The structured interviews, which were audiotaped and then transcribed, took place at the appointed date, and the assessment devices were collected. Those individuals who had not completed the witten 
forms by the interview date were requested to finish them as soon as possible. Reminder phone calls were made every two weeks to those who hadn't returned the forms. When the forms were collected an identifying code number was placed on each of them as well as on the transcribed interviews. 
C - MEASUREMENT IINSTRLREANTS

There were three sources of data in this investigation: the Life History Questionnaire (Appendix I), the Personal Attributes Inventory -- a compcsite of scales and subscales in booklet form that assess eleven personality variables (Appendix VI) and the Structured Interview (Appendix IV).

\section{I.IFE HISTORY QUESTIONINAIEE}

The Life Fistory Questionnaire is a variation of the University of Rhode Island's Clinic quastionnaire. Many of the original quastions were refined and others added in order to meet the needs of this study. The responses to this questionnaire furnished demographic data and other descriptive information pertaining to the background of the suljects and their perents, ano addsd a qualitative dinension to this study.

PERSONAL ATTRIBUTES INVENTORY (PAI)

The following eleven variables were assessed as follows:

1) Depression - Subscale, Jackson's Basic Personality Inventory (20 true-false items)

2) Succorance - Subscale, Jackson's Personality Rasearch Form (20 true-nalse items)

3) Autonciny - Subscale, Jackson's Personality Research Form. (20 true-false items)

4) Interpersonal Affest -- Subscale, Jackson's Fersonality Inventory (20 true-false items) 
5) Innovation - Subscaie, Jackson's Iersonality Inventory (20 true--ralse items)

6) Hypochondriasis - Suoscale, Jackson's Basic Personality Inventory (20 true-false items)

7) Abasenent - Subscale, Jackson's Personality Research Form (20 true-false items)

8) Hostility - Buss-Durkes Hostility Cuilt Scale (75 true-false items)

9) Anxiety - Subscale, Jackson's Personality Inventory (20 truefalse items)

10) Fear - Geer Fear Survey Schedule (51 items, five point scaie), and

11) Sexual Identjty (nasculinity-femininity) - Spence-Helnreich Stapp Personal Attributes Questionnaire (55 iterle, Five choices.

All the irve-false questions were randomized, ard then broken up into two blochs. Each of the remaining two inventories were given in their entiraty, with a block of true-false questions separating these two inventories.

A descriftion of the instruments which comprice the personal Attributes luventory and a discussion of the psychometric properties follows.

a) Jackson Personality Inventory (JPI)

1. General Description

The SPI, an objective, self-report personality inventory, was developed to provice a set of measures of perscnality which heve ini- 
portant implicaticns for an individual's functioning. Jackson chose those personality variatles that he considered to be both interesting ard useful. In addition, he thought these variables would have the potential for furthering an understanding of the personality functioning of the normal or non-psychopathologically disturbed indivicival (Jackson, 1976, McReyrolds, 2978). Some of the variables resemble those defined by personality and social psychologists after considerable research effort. Others, nowever, have not been well-investigated.

The JPI was designed for use with non-psychiatric, non-clinical populations of average or above average intelligence and education. Norms for the JPI were established using the responses of 4,000 students, half male and half female, drawn from a total of 43 American institutions of higher learnjug.

\section{Scoring}

The JPI is comprised of 320 true-false items divided equally into sixteen 20-item scales. The respondents' task is simply to answer true or false, based on whether they consider the item tiue of themselves or agree with its content. For each of the 16 scales, 1.2 of the items are keyed true and $\frac{1}{2}$ are keyed false. The scales were designed in this way in order to mininize the role of a 'yea saying' response set, and to allow definition of each pole of the bipolar scale dimensions with positively worded content (Jacksor, 1976). The scales were developed to be bipolar. The direction of scorirg for a scale was arbitrarily chosen to be in a particular direction (anxiety could just as easily have beer: labeled freedom from anxiety). For each scale, then, ten itens represent the positive pole of the dimension and ten 
1tems represent the negative pole. The higher the testee's score on a particular scale, the higher his/her position on the dimension underlying the scale. Scores may range from 0 to 20 on each scale. All Individuals are believed to possess the personality trait or characteristic to some degree. The higher the score, the greater the probability that the individual will show behavior relevant to the characteristic underlying the score.

With regard to faking and motivated distortion, the characteristics assessed by the JPI are not nearly so evaluative as are the scales found in many personaity questionnaires -- particularly those designed to assess psychopathology -- and thus do not lend themselves readily to faking. In addition, in the construction of the test, the desirability conponent of each item nas s'ipressed in relaticn to its content component. Items were selected which were considerably mcre heaviiy saturated with content rariance tom with desirability variance. Hence, the relativeiy lower propoiticr of desirability variance in JPI itens makes "faking good" or "faking bad" more difi.. ficu1t (Jackson, 1976).

\section{Psychometric Properties}

Jackson provides evidence for the convergent and discrininant validity of the JPI. In particular, the three JPI scales employed in this study, Interpersonai Affect, Innovation and Anxiety, have high valiaity coefficients, $i . \epsilon .$, they correlate well with other measures of these traits.

The reliabiljties of the JPI have been investigated. Internal consistency reliaility (homogeneity) estinates for the JPI were obtained in two studies. The reliability coefficients for Anxiety 
were 0.95 and 0.90 , for Innovation, 0.94 and 0.93 , and for Interpersonal Affect, 0.92 and 0.90 . These values were high.

The Anxiety, Interpersonal Affect and Innovation scales of the JPI (Appendix VII) were used in the researcher's Personal Attributes Inventory (PAI). Following are definitions and descriptions of each of these three variables.

Anxiety: The JPI Anxiety Scale is designed to differentiate indivicuals in the normal range of anxiety rather than to diagnose severe psychopathology. High scorers on this scäle tend to show symptoms often associated with anxiety: worry, apprehension, the state of being easily upset, preoccupation, fearfulness and physical complaints associated with tension. People low on Anxiety are able to remain caln ever in stressful situations and are described as easy going, relaxed, coinposed and collected (McReynolds, 1978). This scale assesses the essentia1ly consistent level of anxiety as it has developed over the course of an individual's iifetime.

Interpersonal Affect: Individuals attaining high scores on this scale are frequently described as identifying closely with cther people and their problems, valuing ciose emotional ties with others, and being concerned about others. Ihey are characterized by defjning trait adjectives such as emotional, tender, kind, affectionate, demonstrative, warm-heartcd, synpathetic and compassionate (Jackson, 1976). Persons obtaining low scores sometines have difficuity relating to people, being regarded as motionaliy unresponsive to others and aloof. Voually they 
prefer inpersonal to personal relationships and report little concern or compassion for other pecple's problems. They may be characterized as unresponsive, distant, hard-hearted, taciturn, unemotional, indifferent and cold (McReynolds, 1978).

Innovation: The purpose of this scale is "to identify a personality dimension that might predispose an individual to seek rovel solutions in a variety of situations" (McReynolds, 1978). People receiving high scores often are characterized as persons who tend towards originality of thought, are motivated to develop novel solutions to problems, value new ideas and like to improvise. Defining trait adjectives include original, innovative, ingenious, productive and imaginative. Low scorers usually report little creative motivation, conservative thinking and a partiaity towards routine activities. Low scorers are defined as routine, literal, prosaic, sober, practical, deliberate and unimaginative (McReynolds, 1978). 


\section{b) Personality Research Form (PRF)}

\section{General Description}

The PRF is another self-report personality inventory developed by Jackson. It has designed to produce a set of scores for personality traits wich are broadly applicable to the functioning of persons in many different situations. This device, like the JPI, focuses on the normally functioning individual rather than the psychopathologically disturbed one. The origin of the personality concepts for the PRF was Murray's Variebles of Persuncility. Murray's notions were modified by Jackson in the light of new research evidence anc his own redefinitions. The bipolar scales were thus developed by carefully defined, theoretically baser conceptions of what each scale should measure (Jackson, 1974).

Norris for the FRr are hased upon separate samples of over 1,000 male and over 1,000 female college stuảents. These groups were assembled from over 30 North American colleges and universities.

\section{Scoring}

The PRF form IA is comprised of 440 true-false items divided equally into twenty-two 20-item scales. The higher the respondent's score on a particular scale, the higher his/her position on the dinension underlying the scale. Scores range from 0 to 20 on each scale. The rationale for the design of the PRF scales is indistinguishable from that of the JPI. (The rature of the personality variables measured in the pNw is different. fron the JPJ, and the JPI has more refined and developed stiatefies for scale development than the PRF.) In the PRF, as in the JPI, every jton is nore heavily saturated with concent varlance than with desirability variance. 


\section{Psychometric Properties}

Evidence is provided by Jackson for the discriminant and convergent validity of the PRF'. Specifically, the three PRF scales used in this study; Succorance, Autonomy and Abasement, have high validity coefficients. As a result of liscriminant and convergent validity studies, it is possible to treat each PRF scale as distinct, and to have confidence that each is providing a unique contribution to assessment (Jackson, 1974).

Jackson examined the PRF (fonn A.A) scales for stability (testretest) and for homogeneity (Kuder-Richardson) reliabilities. For Succorance, Autonomy and Abasement the K.uder-Richardson yielded reliability coeficients of $0.80,0.78$ and 0.65 respectively for one sample of 71 subjects, and $0.78,0.69$ and 0.63 respectively for a sample of 202 stbjects, The tes-retest riliabilities for these same scales wcre $0.84,0.77$ and 0.75 respectively.

The Succorance, Auconomy and Abesenent scales of the PRF (Appendix VIII) were einployed in the Farsonal Attributes Inventory (PAI). The descriptions of these three variabies follow.

Succorance: Those achieving high scores on this scale frequently seek the sympathy, protection, lcve, advice and reassurance of other people; and may feel insecure and helpless without such support. They readily confide difficulties to receptive individuals. The following adjectives are characteristic of the high sccre: trusting, ingratiating, defenseless, help-seeking, pleading, craves affection, requesting, needs protection, conFiding, helpiess, wants advice, seeks support, appealing for 
help, entreating and dependert (Jackson, 1974).

Autonomy: High scorers on Autonomy try to break away from restraints, confinement or restrictions of any kind. They enjoy being unattached and free, and not tied to people, places or obligations. They may be rebeliious when faced with restraints. Descriptive adjectives for high scorers include unmanageable, free, self-reliant, independent, autonomous, rebellious, unconstrained, individualistic, ungovernable, self-determined, non-conforming, uncompliant, undominated, resistant, lone-wolf (Jackson, 1.974 ).

Abasement: Fersons scoring high on Abasement show a high degree of humility. They accept blame and criticism even when not deserved, and expose themselves to situations where they are in an inferiar position. They tend to be self-effacing. Defining trait adjectives are: meek, self-accusing, seif-blaming, obsequious, self-belittıing, surrendering, resigned, selfcritical, humble, apologizing, subservient, obedient, yielding, deferential, and self-subordinating (Jackson, 1974). 


\section{c) Easic Personality Inventory (BPI)}

\section{General Description}

The BPI is a structured self-report inventory recently developed by Jackson to be used in clinical settings. The inventory was designed to measure twelve independent personality dimensions that are relevant to psychopathological behavior. The twelve BPI scales were derived from the MMPI and DPI. Jackson asserts that the twelve BPI constructs "represent the important dimensions or basic sources of variation in the general domain of personality dysfunction". (Kilduff and Velicer, undated). Norms for the BPI are currently being astablished.

\section{Scoring}

The BPI consiets of 240 items divided equally into twelve 20-item bipolar scales. Each scale was balanced for true-false keying (for each scale $\frac{1}{2}$ the items are keyed true and $\frac{1}{2}$ the itcms are keyed false). The higher the testee's score on a scale, the higher his/her position on the dimension underlying the scale. Scores may range from 0 to 20 on each scale. The relatively low proportion of desirability variance in BFI items was achieved by including in the final scales only those items demonstrating a 10w association with social desirability.

\section{Psychometric Properties}

The results regarding the discriminant validity of the BPI scales wers mixed (KiIduff and Velicer, undated) and need to be assessed further; especially in the context of a clinical population.

The reliabilities of the BPI have begun to be examined. Internal consistency reliability (hunogereity) estimates vere obtained for two sampies. The internal consistency coefflcients $(K R-20)$ for Hypochon- 
driasis were 0.77 for a sample of 124 Junior College subjects ard 0.76 for a sample of 168 University subjects. The test-retest reiiability coefficient for Hypochordriasis was 0.74 . The homogeneity coefficients (KR-20) for Depression were 0.78 for the sample of 124 Junior College subjects and 0.79 for the sanple of 168 University subjects. The testretest reliabiity coefficient for Depression was 0.85 . Adequate reliability for these two variables was demonstrated, and there is reason to believe that it would be even higher for a clinical population. EPI scales, in general, compare favorably with the reliability reported for the MPI scales (Kilduff and Velicer, undated).

The researcher's Pexsonal Attributes Inventory (PAI) contains two scales from the PPI: Hypochondriasis and Depression (Appendix IX). The descriptions of these valiabies follow.

Depression: High scorers incline to be down-hearted and show extreme despondency. They consider themselves inadequate, and may be listless and preoccupied. They look at their futures pessimistically. Low scorers, on the other hand, report a usual feeing of confidence, cheerfulness, and persistence, even when experiencing disappointment. They have an optimistic attitude about their futuzes. Hypochondriasis: High scorezs on Hypochondriasis frequently think they are sick. They complain regularly of peculiar pains or bodily dysfunctions. They discuss such topics, and frequently reveal. a preoccupation with their complaints. Low scorers are without excessive tolily concern or preoccupation with physical complaints. Absenteeism due to ill health is Iikeiy to be below average. 


\section{d) Geer Fear Survey Schedule (FSS-II)}

\section{Genexal Description}

The FSS-II is a self-assessment inventory that refers to specific fear inducing stimuli. It was designed primarily as a research tool, and is modeled after Akutagawa's Fear Survey developed in 1956. The Akutagawa scale was constricted by selecting 50 items that were felt to cover most commonly occurring fears.

FSS-II items were selected on an empirical basis. 76 male and 48 female subjects were administered an open-ended quiestionnsire on which they were to list their fears. The subjects were instructed to note the intensity of their fears on a 3-point scale, and include fears that involved no actual danger or pain. Altogether the subjects recorded 111 fears. 51 of these fears occurred two o: more times. These 51 fears vere selected to make up the iten pool for the developwent of the FSS-II. There were eighteen fears jn comon between this pool and Akutagawa's original list (Geer, 1965).

\section{Scoring}

The FSS-II consists of the 51. fears that were fourd two or more times, plus a rating scale tor each fear. Wive rating scale for each Item consists of seven descriptions of different intensities of fear. The respondents are instructed to circle, for each item, the word that most nearly describes the amount of fear they feel toward the object or situation noted in the item. The descriptions of intensity are: none, very little, a little, some, much, very much and terror ( $I=n o n e$, $7=$ terror). Scores may range from $5 i$ to 375 . There is a low negative 
relation between the FSS-II and social desirabllity. Most of the variance associated with the FSS-II is not accounted for by social desirability.

\section{Psychomerric Properties}

The author of the inventory analyzed the reliabilities and validities of his instrument using a sample of 161 tale and 209 fenale subjects. The kuder-Richardson formula was applied, and the overall inteinal consistency reliabijity of tise FSS-II was 0.939 . The female $\mathrm{r}$ was 0.928 and the male $r$ was 0.934 . Geer's Fear Survey Schedule has high internal cousistency reliability. It also correlates significantly (r's from .39 to .57) with the Tayior Manifest Anxiety Scale and the Welsh i Scale. The studies validating a number of individual. items also indicate that the Fear Schedule has good validity (Geer, 1965).

For thie purpose of the Geer FSS-II, "fear is considered to be a negative emotional response evoked by a relatively specific stimulus. The difference between fear and anxiety is thus conceptualized as a difference in the specificity of the eicitirg stiuulus. Fear is a response to a sfecific stimuius and anxiety a response to a more Eenera? or pervasive stimulus" (Geer, 1965). Fears, as measured by the FSS-II, are relativeiy stable phenoriena. According to McReynolds (1968, Vo1. I), total scores on the FSS-II reflect overall anxiety. (See Appendix VI. The Geer FSS-II is part I of the PAI.) 


\section{e) Buss-Durkee Hostility-Guilt Inventory}

\section{General Description}

Most authors have constructed global tests of hostility or aggression, and while a 'Total Hostility' score is obtainable from this inventory, Buss and Durkee's main intention was to construct a ineasure evaluating several different types of hostile and aggressive behavior. J.n addition, they felt that a scale that assesses guilt as a result of the expression of hostility would be useful to include in the inventory.

The items comprising the final form of the inventory were either constructed by the authors, or borrowed fron previous inventories and then modified.

The only norms available are for the 85 college males and 58 college females to whon the inventory was first administered. ivoms are being collected for clinical populations (Buss \& Durkee, 1957).

\section{Scoring}

The inventory contains 75 items: 50 true items and 15 false items, a ratio of four to one. (The items comprising the inventory are lister in Appendix $x$; each item is grouped with other items in its scale, and false items are marked " $F$ ".) The higher the testee's score on a. particular hostility subscale (and on Total Hostility), the higher his position on the dimension underlying the scale.

Social desirability was found to have only a small (but significant) effect on the direction of responding. The smallness of the effect is due to the effort of the constructors of the test to minirize it by a) assuming that anger was present, and inquiring only how it is 
expressed, b) providing justirication for admitting aggressive acts, and c) including clichés and idioms that would find ready acceptance. The effort was to reduce the influence of social desirability by reducing or eliminating it at the source: the actual wording of the item (Buss \& Durkee, 1957).

\section{Psychometric Properties}

Megargee and Menzies in McReynolds (1971, Vol. II) are of the view that the Buss-Durkee inventory rests on a stronger foundation than most. of the other instruments measuring hastility that have been surveyed. With regard to the validity of the inventory, some correlational studies have beén carried out (McReynolds, 1971).

Factor analyses of the scales indicated that there are two principal factors involved, which Buss identifies as aggressiveness and hostility. Others prefer to interpret them as reflecting overt and covert hostility (McReynolus, 1971).

The subclasses of hostility are defined by Buss and Durkee (1957) in the following ways:

a) Assau1t: Physical violence against others. This includes getting into fights with others but not destroying objects (10 itens).

b) Indirect Hostility: Both oblique (i.e., gossip and practical jokes) and undirected aggression (i.e., temper tantrums and slanming doors) (9 items).

c) Irritability: A readiness to explode with negative affect at the least provocation (i.e., quick temper, grouchiness, exasperation and rudeness) (11-iters). 
d) Negativism: Oppositional beinavicr usually directed against authority. There is a refusal to cooperate that varies from passive noncompliance to open rebellion against rules and conventions (5 items).

e) Resentment: Jealousy, envy, and hatred of others. This refers to a feeling of anger at the world and people over real or fantasied mistreatment (8 items).

f) Suspicion: Projection of hostility onto others. This ranges from being distrustfui and wary of people to beliefs that others are being depreciatory or are planning injury (10 items).

g) Verbal Hostility: Negative affect expressed in both style and contert of speech. Style includes arguing, shouting, and screaming; content includes threats, curses, and being hypercritical (13 items).

Guilt is defined by Buss and Durkee (1957) as: feelings of being bad, having done wrong, or sliffering pangs of conscience (9 items). 
F) The Spence-Helmreici-Stapp Personal Aitributes Guestionnaire (PNQ)

\section{Ceneral Description}

The PAQ assesses sex-role stereotypes and masculinity and femininity. Only the portion of the PAQ determining masculinity-femininity (the Self Scale) was administered.

The PAQ is a revision of the Rosencrantz, et al. Sex Role Stereotype Questionnaire (SRSQ). The SRSO consists of 122 tipolar attributes. Spence et a1. found significant sex-role stereotypes (the belief that: men and women differ in some specified characteristic) for both maie and female subjects on 66 oi the SRSQ items. 55 of these were arbitrarily chosen for the $\mathrm{PAQ}$. The self-rating scale is broken down into three subscales: the Male-Valued subscale (23 items), the Female-Valued subscale (18 iteris), and the Sex-Specific subscale (13 itenis). The inclusion of Male-Valued and Female-Valued subscales reflects Spence et al.'s notion of masculinity and fernininity as beirg separate dimensions rather than a single bipolar continuum. The sex-Specific subscale refers to the subjects' conception of the ideal male or femele.

Normative data for the PAQ was obtained by administering it to 248 males and 2.32 female coliege students at the University of Texas at Austin.

\section{Scoring}

Respondents were instructed to rate themselves on each of 55 bipolar itema (the Self Scale). Each item is presented on a five-point scale and no tertion of sex differences jo made (this minimizes the subject's stereotypes fxom influencing self reports). The self-ratings 
are scored by first identifying for each item the stereotypically "masculine" pole. Choice of the extreme masculine choice is scored 4. Choice of the adjacent scale point is scored 3, and so on, down to zero. Correlations with the Marlowe-Crowne Social Desirability Scale. were low (Spence et a1., 1974).

\section{Psychometric Properties}

Alpha coefficients were computed for the Total Self score as a measure of internal consistency. Values of 0.73 and 0.91 were obtained for men and wornen, respectively, on the Self scale. The PAQ has satisfactory homogeneity. Test-retest reliability data are available based on a sample of 31 subjects who retook the PAQ after an interval of approxinately 13 weeks. The reliabilities were 0.80 and 0.91 for men and women, respectively, on the Self scale.

After carrying out an analysis of the $P \Lambda Q$, Spence et al. came to the conclusion that the concept of mascuinity-femininity is more complex than it has heretofore appeared to be. The previous assumption was that a single bipolar dinension is involved, with masculine benaviors at one extreme and feninine behaviors at the opposite. Spence t. al. feel that while men and women differ significantly in masculine/ feminine attributes, men differ from women in that they are somewhat more "masculine" on some attributes and somewhat less "feminine" on others. They suggest that femininity and masculinity are separate dimensions which tend to be positively rather than negatively correlated.

As mentioned, the PAQ is composed of three different types of items; Nale-Valued, Ferrale-Valued and Sex-Specific, The Male-Valued items are 
mainly descriptive of instrumental behaviors and are said to characterize stereotypic men. These "masculine" behaviors concern methods of coping with the external enviromment and getting things done. The Femaik-Valued items are descriptive of expressive behaviors, and aze more stereotypically characteristic of women. These items concern emotional reactivity and concern for others (Spence et a1., 1974). The Sex-Specj.fic items are mixed in content (instrumental and expressive) and assess how stereotypically masculine the ideal male is perceived as being and how stereotypically feminine the ideal female is conceived of being. (The PAQ is reproduced in Appendix VI (PAI), Part III.) 


\section{THE STRUCTURED INTERVIEW}

\section{Genera1 Description}

The attitudinal variables Alienation, Social Activism and Trust in People were irvestigated via an approximately hour-long structured interview condicted by the investigator (this potential source of bias was unavoidable) (Appendix IV). Many of the interview quastions were adapted from pre-existing attitude scales (found in Robirson \& Shaver's Measures of Social Psychological Attitudes, 1973). The rest were constructed by the researcher in order to comprehensively exarine the subtleties of the variables in question. In designing the questions, priority was given to clarity of expression and pleasing conversational style. The variable Alienation was conceived of as being made ip of four components: powerlessness, social isolation, anomie, and meaninglessness of life (Robinson \& Shaver, 1973). Questions were developed to investigate a11 four elements, and were derivec from a wide variety of attitude measures of Alienation. The questiors used to explore Trust in People originated mainiy in Rosenberg's (1957) Faith in People Scale (Robiuson \& Shaver, 1973). The Social Activism queries were formulated after exanining attitude scales evaluating social responsibility, and abstracting the factors that this atilture variable appeared to be comprised of .

\section{Scoring}

The Structured Interview is made up of 24 open-ended questions (with follow-up questions designed as probes) which examine the variables. Alienation is investigated by thirteen interview itens: Anomie is assayed by four questions and Fowerlessness, Meaninglessness of 
Life, and Social Isolation are each examined by three questions. Social Activism is explored by six queries, end Fatth in People by five. Each of the responses was rated by two iridependent scorers on a bipolar scale of 100-500 according to carefully designed scoring criteria (Appendix V). The scale for each item consists of five descriptions cf how close the response comes to reflecting the variable being assessed. The descriptions are: very iittle, a little, some, much, very much $(1.00$ = very Iittle, 500 = very much $)$.

After all the Alienation resporses were independently scored, each component of Alienation (e.g. Anonie) was given a rating by each scorer (by computing the mean of the scores on the responses comprising the component). The mean of these four components was that rater's Alienation score (for a particular subject). Social Activistn and Faith in People scores were arrived at by computing the mean of the scores on the responses that make up the attitudinal variable. After: scoring was completed by both scorers, deviations in their scoring of more than one hundred scale points on a response, which occurred in only 3.7\% of the responses, were discussed in order to arrive at a compromise final score on that response. When the two evaluators differed on $a$ response by one hundred points or less, the mean of the scale scores that each assigred to the response was taken as the final score on the response. Final scores for all the variables and components were recouputed using the final scores for each response.

Scoring using a double-blind paradigm to mitigate the effects of bias were not possible. Firstly, both of the scorers were aware of the purposes of the research. Secondly, a1though the interview transcriptions were labeled simply by numbers, the Children of Survivors 
were asked a probing question that controis were not. (This immediately Identified them as Survivors' Children. One of the scorers, however, was ignorant of which Experimental group the subject was in.)

\section{Psychometric Properties}

The investigator and her dissertation supervisor agreed on the content validity of the questions after they independently examined them (content validity refers to whether the selected test items are truly representative of all possible items in the content area of the property being measured). All the Alienation questions and Trust in People items, and many of the Social Activism queries, were adapted from items on existing measures of sociai psychological attitudes. The validities of those measures had been previously established.

The internal scnsistency of the Strucluned Interview was not formally investigated. The variables rere defined systematically, however, and much attention was giver to question writing, revising, and editing.

Reliability between the scorers was assessed. The scores indepentently arrived at by the individual. raters on each of the three variables and on each of the components of Alienation were compared. The interrater reliabilities vere uniformly high. The Pearson correlations between the two rater's scores for the seveil dependent variables were significant at $\mathrm{p}<.0009$. The lowest correlation was for Anomie and was .7850. The highest was for Social Activism and was .8849 .

Following are descriptions of the attitude variables investigated. The variable Alienation is defined and measured through four different components. 
Faith in Feople (Trust): An individual who has faith in people has confidence in the tristworthiness, nonesty, goodness, generosity and trotherliness of people in general (Robinson \& Shaver, 1973).

Alienation: An alierated person often feels estranged from the society and the culture that it carries (Robinson \& Shaver, 1973).

Anomie: The person who is in a state of anomie experiences normlessness in our society and feels that the norms of proper conduct are not recognized or subscribed to (Robinson is Shaver, 1973).

Powerlessness: People who feel powerless have low expectancies for the control of events. They feel as though they have little control over the occurrences in their environments (Robinson \& Shaver, 1973).

Meaninglessness of Life: The person who finds life meaningiess experiences existence as senseless, without significance or value. Social Activism: An individual who scores high or Social Activism is a person who has a sense of social responsibility and an orientation towards helfing others even when thexe is nothing to be gained fron than. This individual considers those activities which involve service and help to others as extremely worthwhile. Defining adjectives for Social Activism include: social responsibility, participation-activisin, selflessness for a cause, civic-minded, and questioning of authority. 


\section{RESULTS}

Each of the dependent variables evaluated in the PAI and examined in the Structurad Interview was analyzed using a $2 \times 2 \times 2$ analysis of variance. The three-way ANOVA assessed the effects of Canp Experience (Children of Survivors and Controls), Ser (Hale and Female), and Developmental Level (Children of parents who were Adolescents during WW II and Children of parents who were AdrIts during WW II). See Figure 1 for a sketch of this design. Tables 7 and 8 preserit the means and standard deviations for all the defendent variables investigated at each level of each of the indapendent variables. Tables 9 and 10 show the means and standard deviations for all the depenient variabies at each of the two Developrental Levels and each of the two lieveis of Camp Experience. Tables 11 and 12 Iist the means and stardard aeria.tions of all tiie dependent variables at each of the levels of Camp rx-perience. Tables 13 and 14 give the means and standard deviations of those dependent variables for wich a significant main affect other than Camp Experience was found.

The results of the analyses of variance performed on each of the PAI variabies are presented first. They are followed by the results for the Structured Intcrview variables. Results statistically significant at the .10 level are found in Table 15. The .10 level cf probability was ured to evaluate the relevent F-ratios because, in addition to statistically significant differences (at the .05 levei of significance), the researcher was intezested in identifying strong trends. Resules which didn't attain the conventional level of signifi- 
cance may provide a foundation for follcr-up studies. Furthermore, the independent variable, Concentration Camp Experience, is quite complex, and may be affected by a number of other variables. The complicated nature of the independent variable is an additional reason for adopting the .10 significance 1 evel.

of the twenty personality artributes investigated, Children of Survivors were different from Controls on eleven. The investigacor's expectation of the direction of the difference was confinned. In addition, the mean scores on the measures (dependent variables) for which normative data exist, fell within the normal range. 


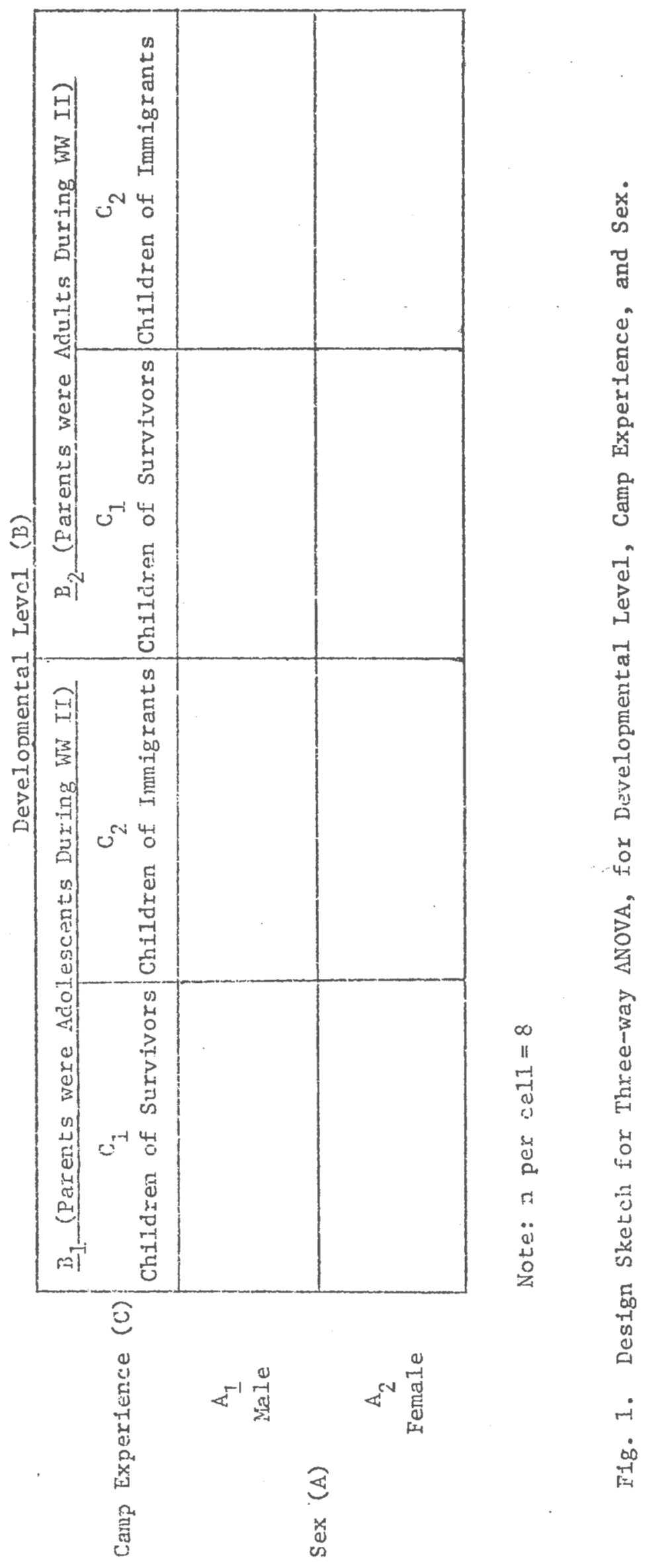




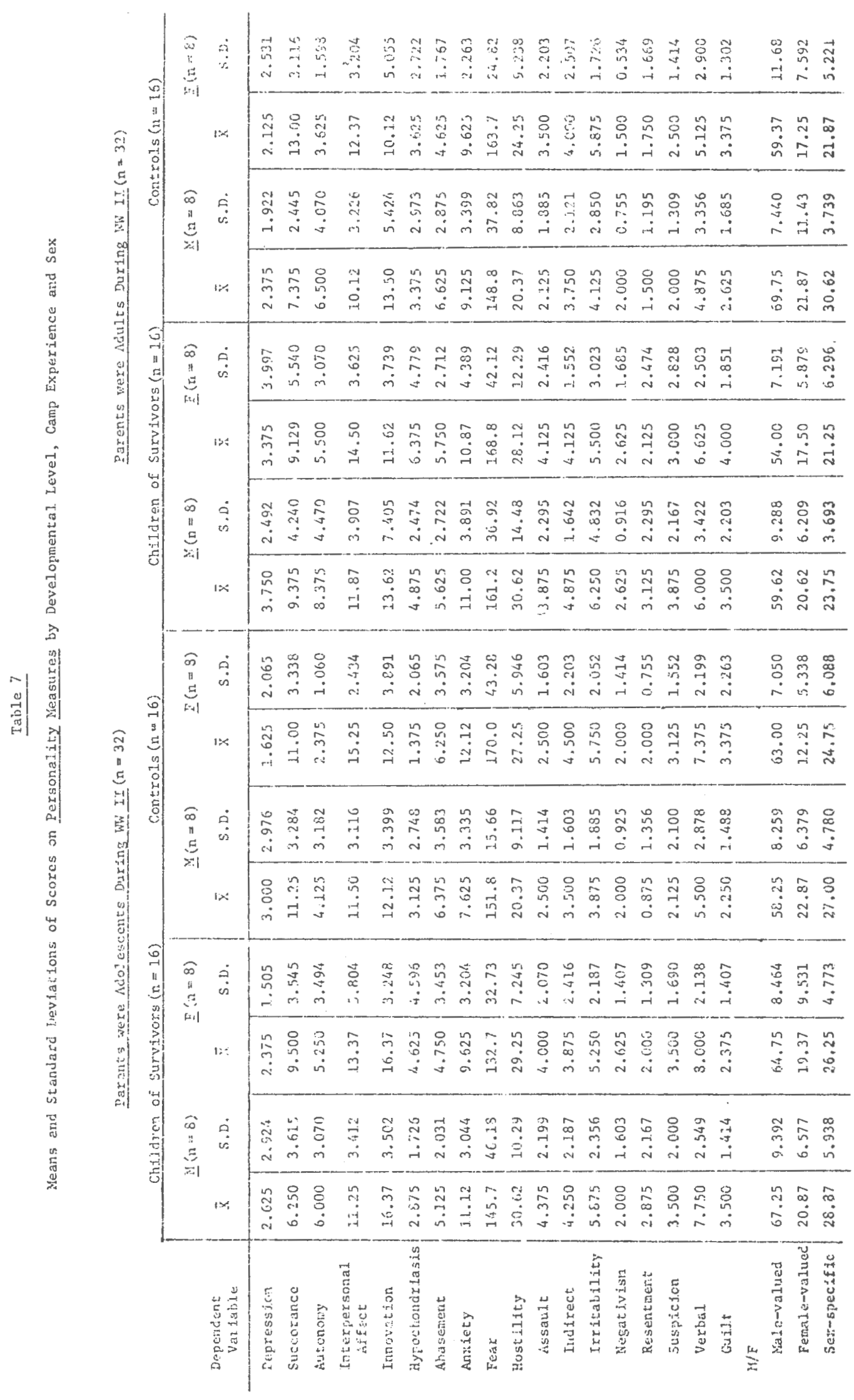




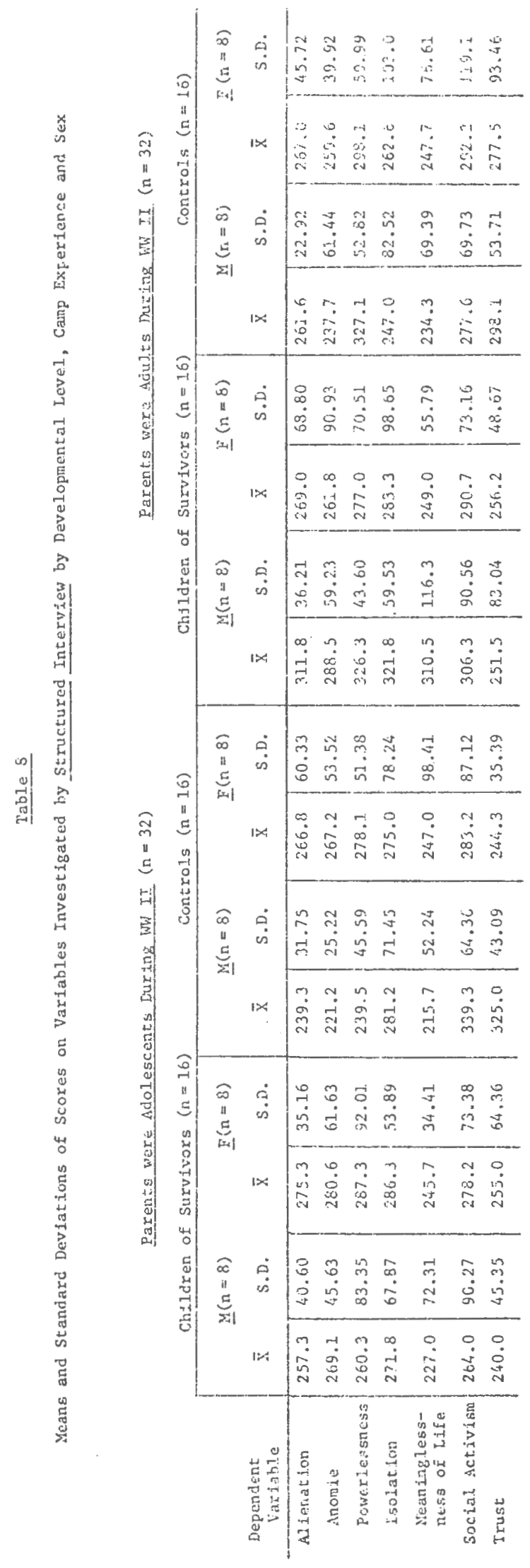




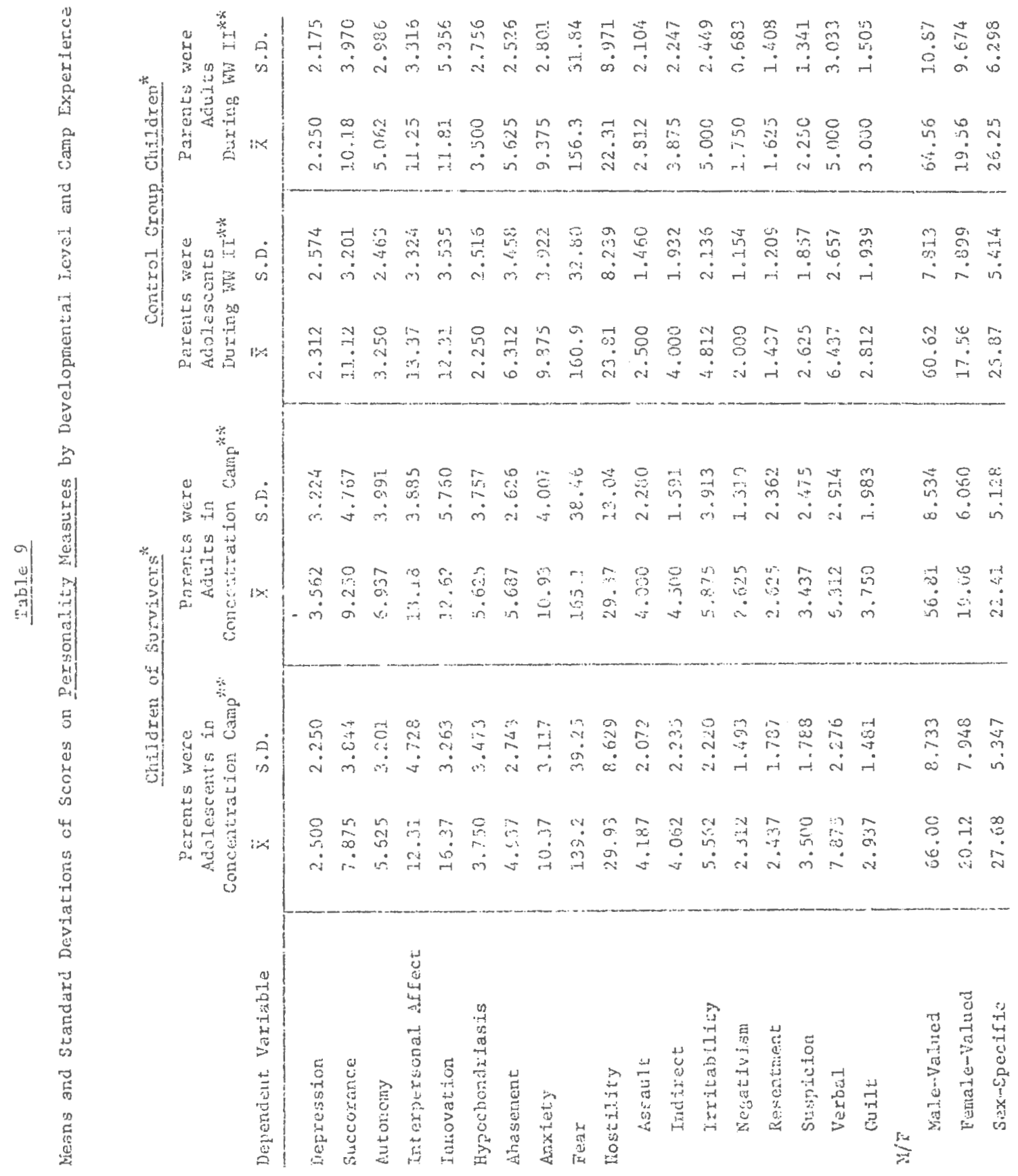




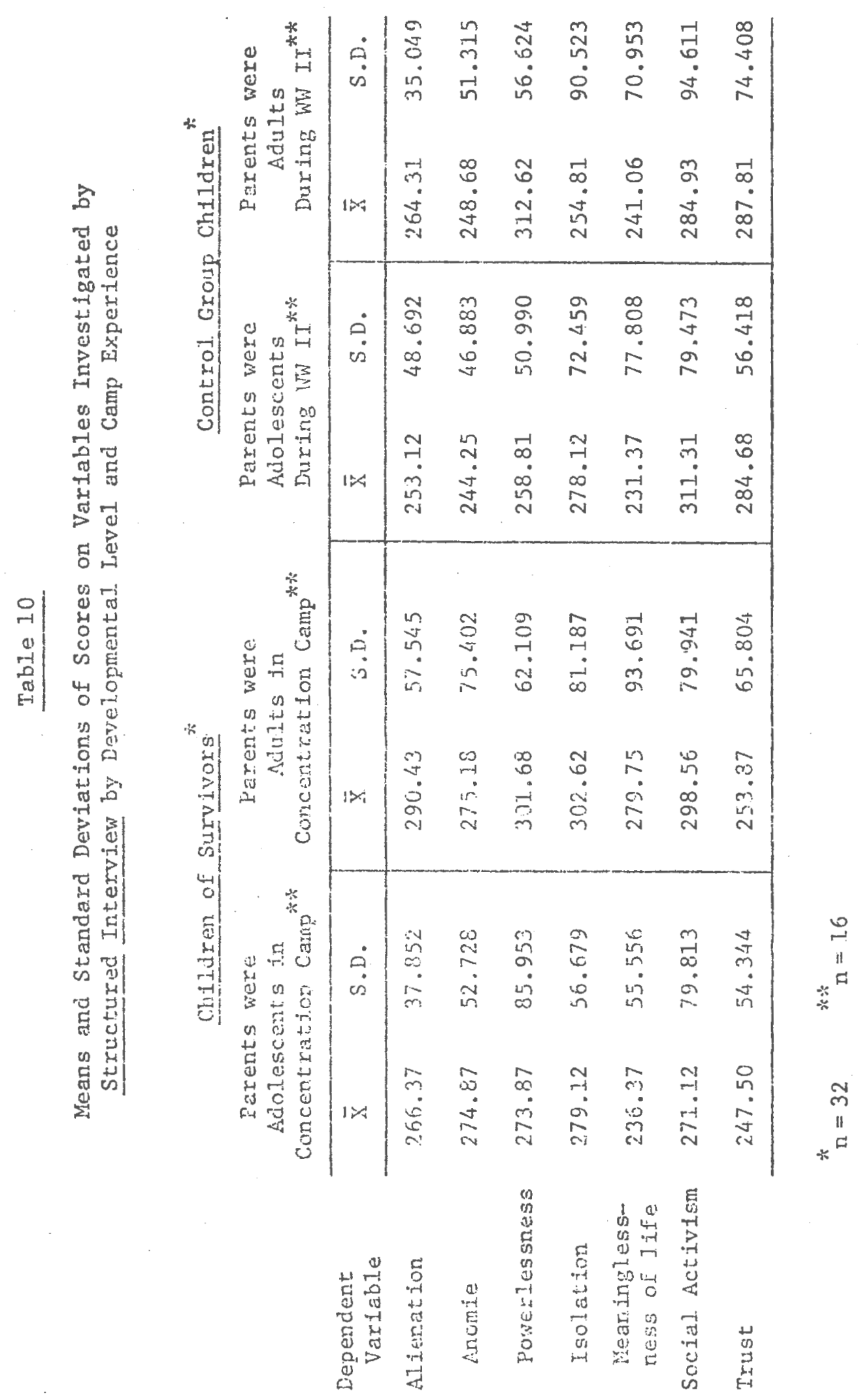




\section{Table 11}

Means and Standard Deviations of Scores on Personality Measures by Camp Experience

\section{Children of Survivors* Control Group Children*}

\begin{tabular}{|c|c|c|c|c|}
\hline Depencient: Variä́le & $\overline{\mathrm{X}}$ & S.D. & $\overline{\mathrm{x}}$ & S.D. \\
\hline Depression & 3.031 & 2.788 & 2.281 & 2.345 \\
\hline Succoranca & 8.562 & 4.317 & 10.65 & 3.579 \\
\hline Autonony & 6.281 & 3.621 & 4.156 & 3.027 \\
\hline Interpersonal Affect & 12.75 & 4.280 & 12.31 & 3.440 \\
\hline Innovation & 14.50 & 4.983 & 12.06 & 4.471 \\
\hline Hypochondriasis & 4.687 & 3.684 & 2.875 & 2.673 \\
\hline Abasement & 5.312 & 2.669 & 5.968 & 2.999 \\
\hline Arxiety & 10.65 & 3.543 & 9.625 & 3.362 \\
\hline Tear & 152.1 & 40.41 & 158.6 & 31.89 \\
\hline Hostility & 29.65 & 10.88 & 23.06 & 8.507 \\
\hline Assault & 4.093 & 2.145 & 2.656 & 1.789 \\
\hline Indirect & 4.281 & 1.921 & 3.937 & 2.062 \\
\hline Irricability & 5.718 & 3.133 & 4.906 & 2.262 \\
\hline Negativism & 2.468 & 1.390 & 1.875 & 0.941 \\
\hline Resentment & 2.531 & 2.063 & 1.531 & 1.294 \\
\hline Suspicion & 3.468 & 2.124 & 2.437 & 1.605 \\
\hline Verbaj. & 7.093 & 2.692 & 5.718 & 2.898 \\
\hline Guilt & 3.343 & 1.770 & 2.906 & 1.710 \\
\hline \multicolumn{5}{|l|}{$M / F$} \\
\hline Male-valued & $61 . .40$ & 9.692 & 62.59 & 9.527 \\
\hline Female-valued & 19.59 & 6.974 & 1.8 .56 & 8.747 \\
\hline Sex-Specific & 25.04 & 5.810 & 26.06 & 5.781 \\
\hline
\end{tabular}

$$
\stackrel{*}{n}=32
$$




\section{Table 12}

Means and Standarä Deviations of Scores on Variables Investigated by Structured Intervjew by Camp Experience

\begin{tabular}{|c|c|c|c|c|}
\hline \multirow[b]{2}{*}{ Dependent Variaìie } & \multicolumn{2}{|c|}{ Chiidren of Survivors* } & \multicolumn{2}{|c|}{ Control Group Children } \\
\hline & $\bar{X}$ & S.D. & $\bar{x}$ & S.D. \\
\hline Alienation & 278.40 & 49.447 & 258.71 & 42.118 \\
\hline Anomie & 275.03 & 64.002 & 246.46 & 48.402 \\
\hline Powerlessness & 287.78 & 75.105 & 285.71 & 59.639 \\
\hline Isolation & 290.87 & 71.100 & 266.46 & 81.521 \\
\hline $\begin{array}{l}\text { Meaninglessness } \\
\text { of life }\end{array}$ & 258.06 & 78.907 & 236.21 & 73.413 \\
\hline Social Activism & 284.84 & 79.805 & 298.12 & 86.988 \\
\hline Trust & 250.68 & 59.454 & 286.25 & 64.974 \\
\hline
\end{tabular}

${ }_{\mathrm{n}}=32$ 
Table 13

Means and Standard ieviations of Scores on Personality Measures for which a Significant viain Effect of Sex was Eourd

\begin{tabular}{l|cc|cc}
\multicolumn{2}{l}{} & \multicolumn{2}{c}{ Male Subjects* } & \multicolumn{2}{c}{ Femaie Subjects* } \\
Dequencient Variable & $\overline{\mathrm{X}}$ & S.D. & $\overline{\mathrm{X}}$ & S.D. \\
\hline Succorance & 8.563 & 3.818 & 10.65 & 3.575 \\
Autonony & 6.250 & 3.877 & 4.188 & 2.717 \\
Irterpersonal Affect & 11.18 & 3.326 & 13.87 & 3.933 \\
Fenale-Valued $(M / F)$ & 21.56 & 7.616 & 16.59 & 7.415 \\
Sex-Specific $(M / \bar{L})$ & 27.56 & 5.105 & 23.53 & 5.742
\end{tabular}

$*_{n}=32$

Table 14

Means and Standard Deviations of Scores on Pexsonality Measures for which a Significant Main Effect of Developmental Level was Founc

Children of Parents who were Adulescents

Dependent Variable
Autonomy
Innovation
Verbal (Hostility)
nypochondriasis
Sex-Specific (M/F)
Powerlessness
$* \quad \begin{aligned} & n \\ & n\end{aligned}=32$
During IT $I I^{*}$

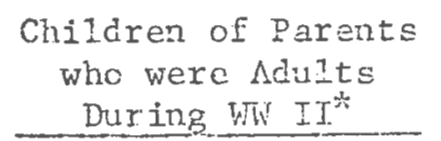

$$
\overline{\mathrm{X}}
$$

S.D.

$\overline{\mathrm{x}}$

S.D.

$\begin{array}{ll}4.438 & 3.058 \\ 14.34 & 3.932 \\ 7.156 & 2.541 \\ 3.000 & 3.079 \\ 26.71 & 5.378 \\ 266.3 & 69.93\end{array}$

6.000

3.742

12.21

5.488

5.656

3.001

4.563

3.417

24.37

5.972

307.1

58.72 
Tit $1 \geq \geq 5$

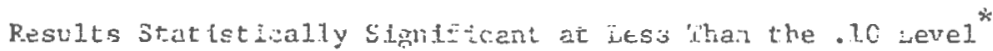

\begin{tabular}{|c|c|c|c|}
\hline Dependent Variablea & $\begin{array}{l}\text { Jadefencient } \\
\text { ratujibles } x * x\end{array}$ & $\mathrm{~F}$ & P-Valus \\
\hline \multirow[t]{3}{*}{ Autonotiy } & $A$ & 6.587 & .012 \\
\hline & $\mathrm{B}$ & 3.838 & .055 \\
\hline & $c$ & 7.008 & .010 \\
\hline \multirow[t]{3}{*}{ Succorance } & $\Lambda$ & 5.012 & .029 \\
\hline & $c$ & 5.012 & .029 \\
\hline & $A \times B \times C$ & 0.281 & .015 \\
\hline \multirow[t]{2}{*}{ Innovation } & $\underline{\mathrm{D}}$ & 3.335 & .073 \\
\hline & $\mathrm{C}$ & 4.398 & .041 \\
\hline Interpersunäl Liffect & A & $8.3 ; 9$ & .005 \\
\hline hostility & $\mathrm{c}$ & 6.941 & .011 \\
\hline Assaul t & $c$ & 7.963 & .007 \\
\hline Irritabilityy & $A \times C$ & 3.241 & .077 \\
\hline Negntivism & $\mathrm{C}$ & 3.777 & .057 \\
\hline \multirow[t]{2}{*}{ Resentrucni: } & $c$ & 5.240 & .026 \\
\hline & $A \times C$ & 3.459 & .068 \\
\hline Suspícion & b & 4.524 & .038 \\
\hline \multirow[t]{2}{*}{ Vexbal } & $\overrightarrow{5}$ & 4.656 & .035 \\
\hline & $\mathrm{C}$ & 3.912 & .053 \\
\hline \multirow[t]{2}{*}{ Wypochondriasis } & F & 3.85 .1 & .055 \\
\hline & c & 5.182 & .027 \\
\hline Anxiety & $A \times C$ & 3.516 & .066 \\
\hline \multirow[t]{2}{*}{ Mele-valued } & $A \times B$ & 4.385 & $.04]$ \\
\hline & $B \times C$ & $9.0 \%$ & $.00^{\circ}$ \\
\hline Female-valued & A & 6.795 & .012 \\
\hline \multirow[t]{3}{*}{ Sex-sperifis } & $A$ & 9.788 & .003 \\
\hline & B & 3.309 & .074 \\
\hline & $3 \times 2$ & 4.452 & .039 \\
\hline \multirow[t]{2}{*}{ Alienation } & $\mathrm{C}$ & 3.063 & .086 \\
\hline & $A \times 3$ & 3.403 & .070 \\
\hline Anomie & C & $3.9 ? 6$ & $.05 ?$ \\
\hline \multirow[t]{2}{*}{ Poverlestness } & B & $6.38 / 4$ & .014 \\
\hline & $A \times B$ & 4.067 & .030 \\
\hline \multirow[t]{2}{*}{ Irust: } & $c$ & 5.361 & .024 \\
\hline & $A \times C$ & 3.579 & .054 \\
\hline Fear & $\mathrm{B} \times \mathrm{C}$ & 2.907 & .094 \\
\hline
\end{tabular}

* The degreas of freedem for the pitatistic ars i and 56.

*t. The main effect of the indeperdent variable sax is rforesciteri by A. The nain effect of the independent variable Develepmenral Level is represent ed by $B$.

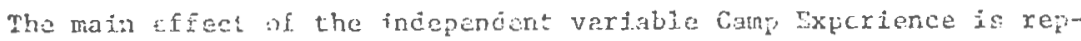
rissuted by $C$.

Intcractions are reprasentind by $x$. 
DEPENDENT VARIABLES COMPRISING THE PAI

\section{Alitonomy}

A significant main effect was obtairec for Camp Experience $(F=7.098, d f=1 / 56, p=.01), \operatorname{Sex}(F=6.687, d f=1 / 56, p<.05) . \quad$ A main effect trend was present for Developmental Level $(F=3.838$, df $=1 / 56$, $p<.06)$. Children of Concentration Camp Survivors were significantly more autonomous than Controle. Males were more aitonomous than Females, and Children of parents who were Adu1ts during WW II were somewhat more autonomous than Children of those who were Adclescents during WW II (see Appendix $X I$ ).

\section{Succorance}

The three-way ANOVA revealed a significant main effect for Camp Experience $(F=5.012, \mathrm{~d} f=1 / 56, p<.05)$ and $\operatorname{Sex}(F=5.02, \mathrm{~d} f=1 / 56$, p . 05). Children of Concentration Canip Survivors had a significantiy lower mean on succorance than iontrol group children. Women had a higher mean than men on succorance. The seccnd-prder interacticn cf Camp Experience, Sex anủ Developmental Level was also significant $(F=6.281, \mathrm{~d} f=1.156, \mathrm{p}<.05)($ see Appendix XI).

An investigation of aimpla effects was conducted by using indefrendent samples t-tests to compare the means for eight groups (sach of which constitutes a cell in the basic experimental design): Male Children of Survivors whose parents were Acolescents during WW II, MaIe Controls whose perents were faolescents during WW II, Male Children of Survivors whose parents were Adults during mi II, Nale Controls viose parents were Adults during W IT, Fenale Children of Survivers whose 
parents were Adults during WW II, Female Children of Survivors whose parents were Adolescents during WW II, Fomale Controls whose parents were Adults during wh II, and Ferale Controls whose parents were Adolescents during WW II. Tables 16,17 and 18 summarize the data upon which the various t-tests were performed.

$+r$

İble 16

Mean Succorance Scores for Children of Survivors and Controls at Each Level of Sex and Developmental Level

\begin{tabular}{l|c|c|c|c} 
& \multicolumn{2}{c}{$\begin{array}{c}\text { Parents were Adults } \\
\text { During WW II }(n=32)\end{array}$} & \multicolumn{2}{c}{$\begin{array}{c}\text { Parents were Adolescents } \\
\text { During IW II }(n=32)\end{array}$} \\
Sex & $\begin{array}{c}\text { Children of } \\
\text { Survivors }(n=16)\end{array}$ & Controls $(n=16)$ & $\begin{array}{c}\text { Children of } \\
\text { Survivors }(n=16)\end{array}$ & Controls $(n=16)$ \\
\hline Males & 9.38 & 7.38 & 6.25 & 11.25 \\
Females & 9.13 & 13.00 & 9.50 & 11.00 \\
\hline
\end{tabular}

Note: $n$ per cell $=8$

$\underline{\text { Table } 17}$

Mean Succorance Scores for Males and Females at Each Level of Camp Experience and Deveíopmental Level

\begin{tabular}{l|c|c|c|c} 
& $\begin{array}{c}\text { Parents were Adu1ts } \\
\text { During WW II }(\mathrm{n}=32)\end{array}$ & $\begin{array}{c}\text { Parents were Adolescents } \\
\text { During WW II }(\mathrm{n}=32)\end{array}$ \\
$\begin{array}{l}\text { Camperience } \\
\text { Exples }(\mathrm{n}=16)\end{array}$ & Females $(\mathrm{n}=16)$ & Males $(\mathrm{n}=16)$ & Females $(\mathrm{n}=16)$ \\
\hline $\begin{array}{c}\text { ChIldren of } \\
\text { Survivors } \\
\text { Controls }\end{array}$ & 9.38 & 9.13 & 6.25 & 5.50 \\
\hline
\end{tabular}

Note: $n$ per cell $=\varepsilon$ 
Table 18

Mean Succorance Scores for Developmenta]. Level at Each Level of Camp Experience and Sex

\begin{tabular}{|c|c|c|c|c|}
\hline \multirow[b]{2}{*}{$\begin{array}{c}\text { Camp } \\
\text { Experience }\end{array}$} & \multicolumn{2}{|c|}{ MALES $(\mathrm{II}=32)$} & \multicolumn{2}{|c|}{ FEMALES $(n=32)$} \\
\hline & $\begin{array}{l}\text { Darents were } \\
\text { Adults During } \\
\text { Wh II }(\mathrm{n}=16)\end{array}$ & $\begin{array}{l}\text { Parents were } \\
\text { Adolescents During } \\
\text { WW II }(\mathrm{n}=16)\end{array}$ & $\begin{array}{l}\text { Parents were } \\
\text { Adults During } \\
\text { wh II }(\mathrm{n}=16)\end{array}$ & $\begin{array}{c}\text { Parents were } \\
\text { Adolescents During } \\
\text { W! II }(\mathrm{n}=16)\end{array}$ \\
\hline $\begin{array}{l}\text { Children of } \\
\text { Survivors }\end{array}$ & 9.38 & 6.25 & 9.13 & 9.50 \\
\hline Controls & 7.38 & 11.25 & 13.00 & 11.00 \\
\hline
\end{tabular}

Note: in per cell $=8$

The tests revealed a sinple effect $(p<.01)$ of Camp Experiance for male children of individuals who vere adolescents during WW II. Male Children of Survivors whose parents were Adolescents during IW II had significantly lower scores on Succorance than Male Controls whose parents were Adolescents during WW II. No other significant simple effects of Canp Experience vere found (see Table 16, Figure 2, and Table 19). The significant difference between the means of Male Chluren of Survivors whose paronts were Adolescents during WW II and Male Controls whose parents were Adclescents during WW II accounts for the main effect of Carnp Experience.

In adition, there is a significant simple effect $(p<.001)$ of Sex for Controls whose parents were Adults during wN II (see Table 17, Figure 3, and Table 19). Females had a significantly higher mean than Hales. Since no other significant simple effects of Sex were obtained, 


\section{Table 19}

Simple Effects Tests on the Second--Order Interaction

of Camp Experience $\times$ Sex $\times$ Developmental Leve 1

for the Dependent Variable Succorance

Comparison of Groups on

Mean Succorance Score

t $\quad$ Probability

$M S$ Adults and $M C$ Adults

1.08

N.S.

F S Adults and F C Adults

1. 61

N.S.

M A Adolesc. and M C Adolesc.

2.71

$\mathrm{p}<.01$

F S Adolesc. and F C Adolesc.

0.82

N.S.

$M S$ Aduits and $F S$ Adults

0.09

N.S.

M C Adults and F C Adults

3.76

$\mathrm{p}<.001$

M S Adolesc. and F S Acolesc.

1.70

N.S.

$\mathrm{M} C$ Adolesc. and $\mathrm{F} C$ Adolesc.

0.14

N.S.

M S Adults and M S Adolesc.

1.48

N.S.

M C Aduits and M C Adolesc.

2.50

$\mathrm{p}<.05$

$F S$ Aduits and $F S$ Adolesc.

0.15

N.S.

F C Adults anc F C Adolesc.

1.16

N.S.

Note: d.E. $=1 \dot{4}$

n per $\operatorname{cel} 1=8$

* M S Adults = Male Children of Survivors whose parents were Adults nuring WN II.

M C Adults = Male Controls whose parents were Adults durirg Wh II.

F S Adults =- Female Crildren of Survivors whose parents were Adults during WW II.

F C Adults = Female Controls whose parents were diults during WW II.

I S Adolesc. = Male Children of Survivors whose parents were Adolescents during IV II.

MC Adolesc. = Male Controls whose parents were Adolescents during WW II.

F S Adolesc. = Female Children of Survivors whose parents were Adolescents during WN $I$ I.

F C Adolesc. = Female Controls whose parents were Adolescents during WW Ir. 


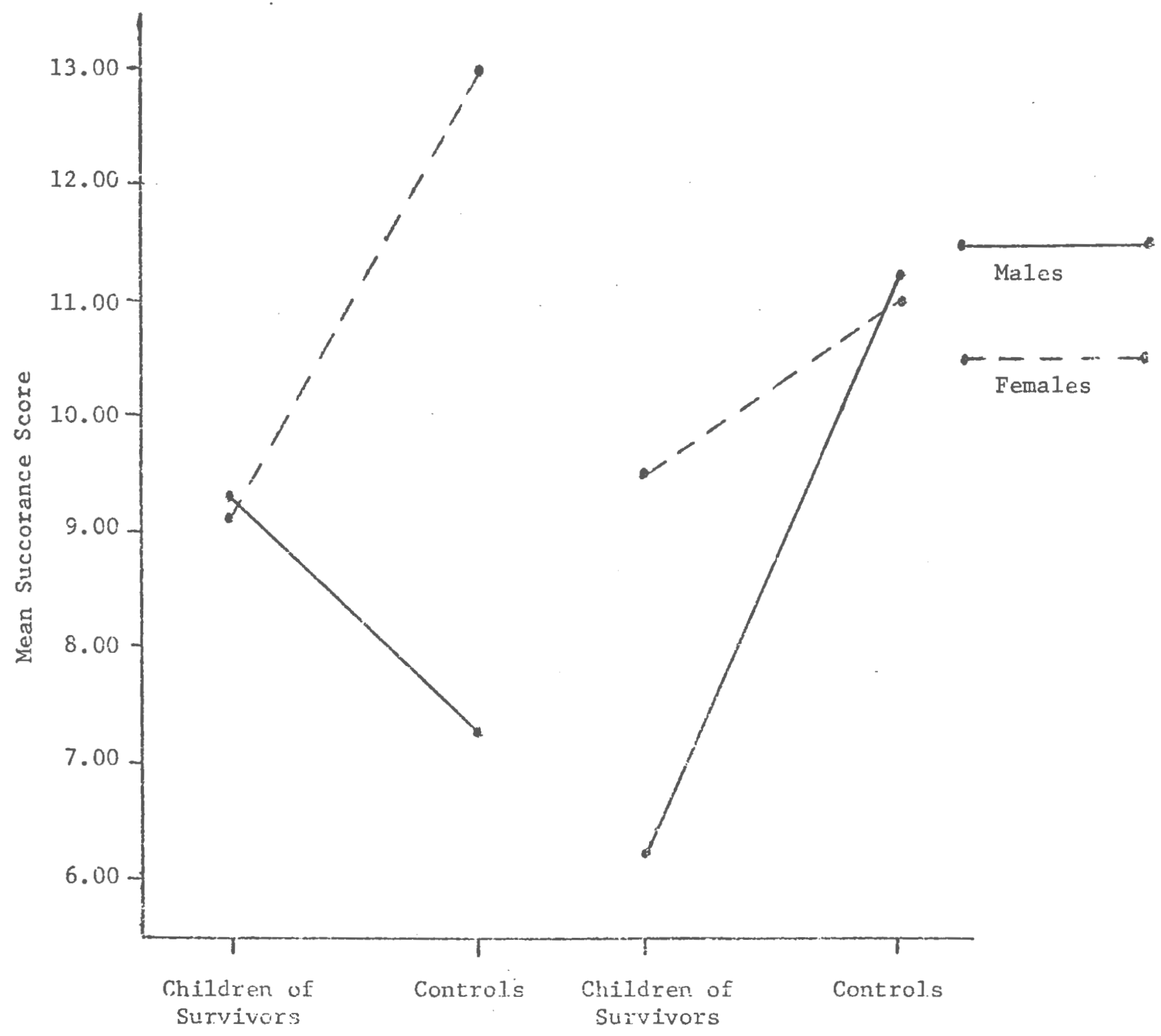

CHILDREN OF PARENIS

WHO WERE ADULTS

DURING WT II
CHILOREN OF PARENTS

WHO WERE ADOLESCENTS

DURING TST II

Figure 2. Succorarice scores as a function of Canp Experience and Sex at both Developmentai Levels. 


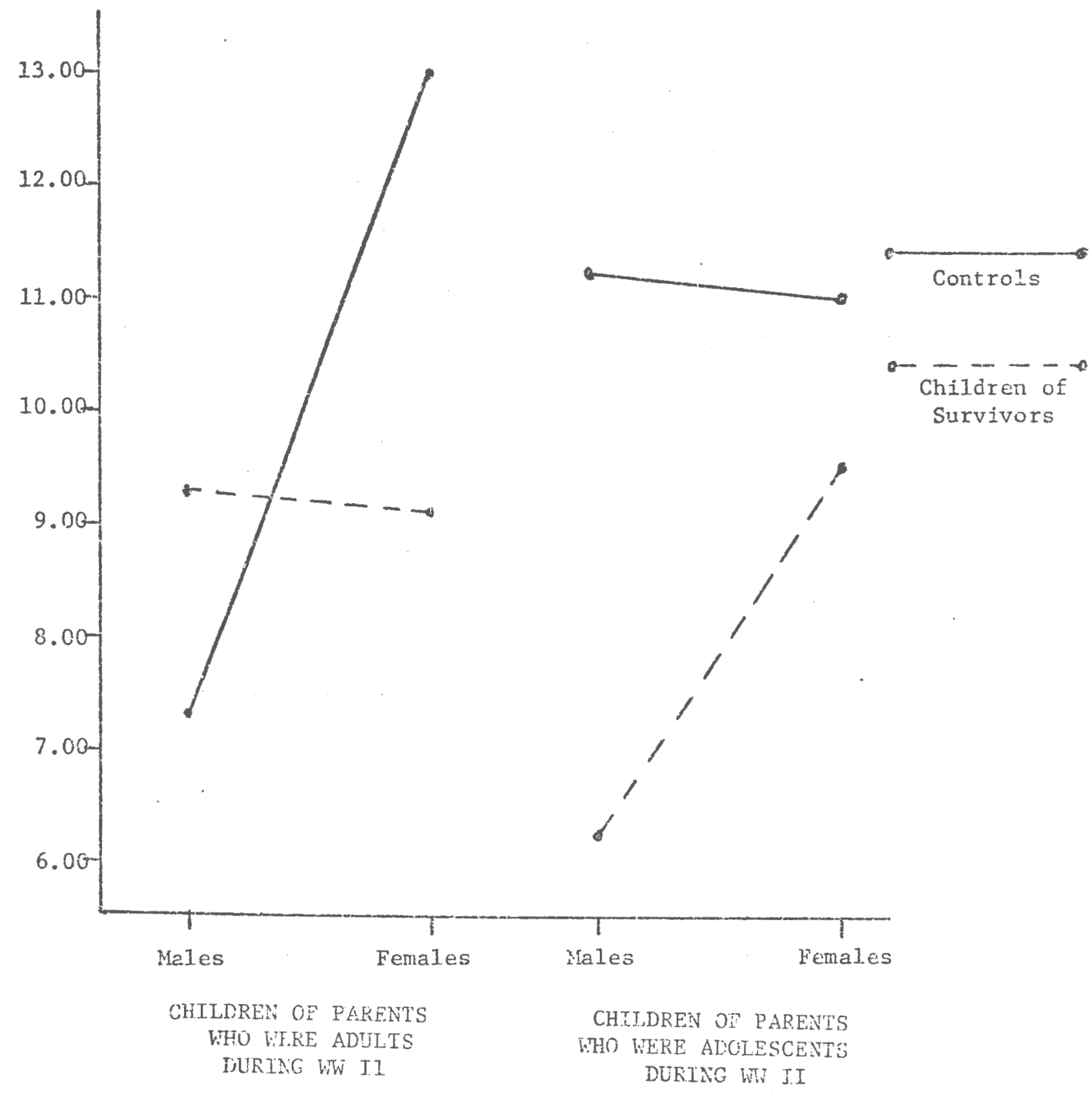

Figure 3. Succorance scorts as a function of Sex and Cain Experience at both Developriental Levels. 


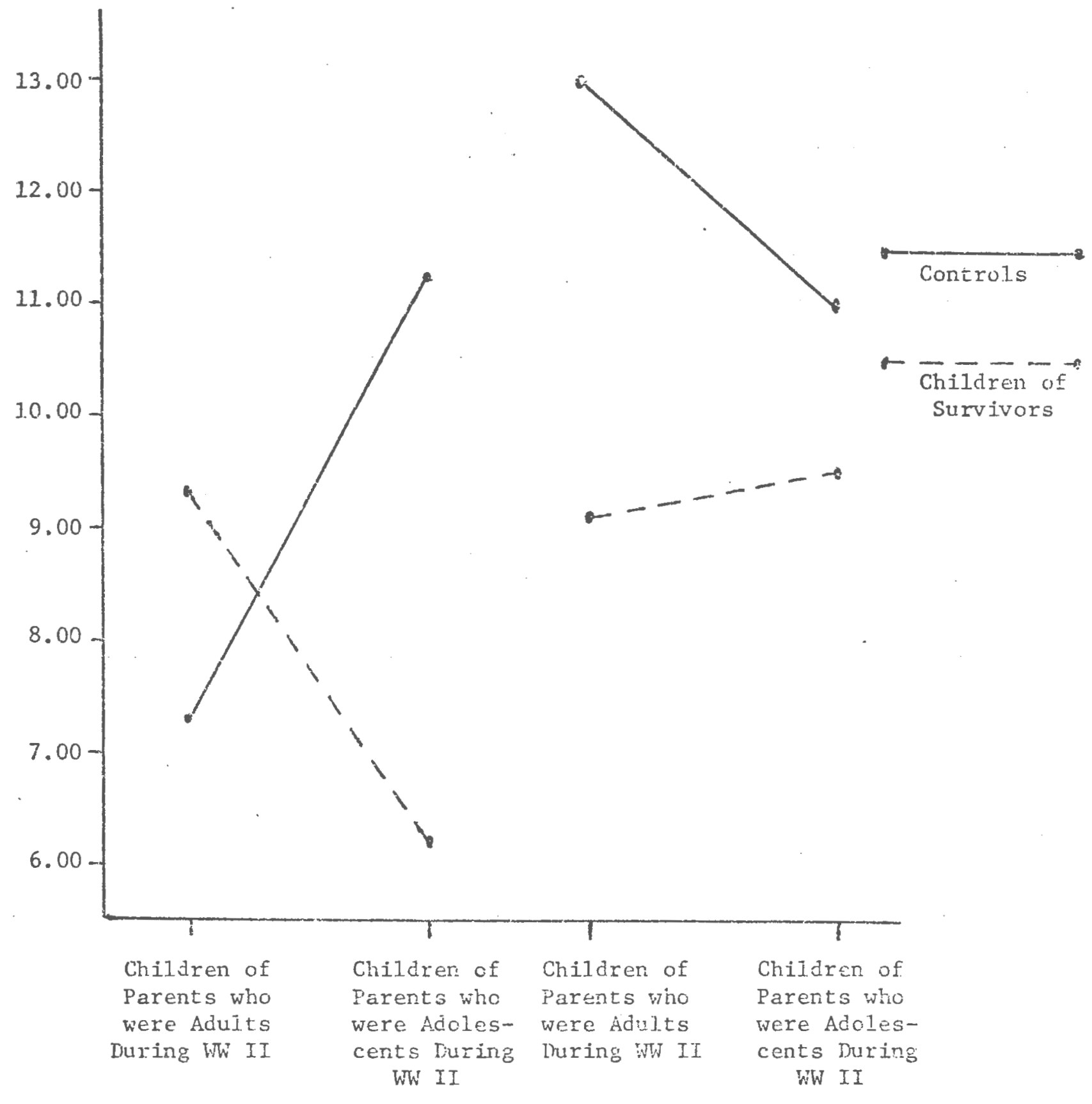

MILES

FEMALES

Figure 4. Succorance scores as a function of Developmenta1 Level and Camp Experience at each level of sex. 
the large difference between the means of liaie and Female Controls whose parents were Adults during WW II acconnts for the main effect of Sex. Finally, the analysis of the second-order interaction showed a significant simple effect $(p<.05)$ of Developmental Level for Male Controis. Male Controls whose parents were Adolescents during WW II had a significartly higher irear on Succorance than Male Controls whose parents were Adults during. WW II. No other significant simple effects of Developmental level were obtained (see Table 18, Figure 4, Tabie 19).

\section{Innovation}

A significant main effect was obtained for Camp Experience $(F=4.388$, $\mathrm{df}=1 / 56 ; \mathrm{p}<.05)$. This indicated that Concentration Camp Survivors' Children were more innovative than Controls. A main effect trend was present for Developmental Level $\left(\frac{F}{i}=3.325, \mathrm{~d} f=1 / 56, \mathrm{p}<.1\right)$. Childien of parents who vere Adolescents during NW II were marginally more inacvative than Children of parents who vere Adulis during Wh II (see Appen$\mathrm{d} \mathrm{ix}$ XI)

\section{Interpersonal Affect}

A significant main effect was ubtained for $\operatorname{Sex}(F=8.399$, df $=1 / 56$, $p<.01$ ). Wonten nad a higher mean than men on intezpersonal affect (see Apperdix $X I)$.

\section{Hostility}

A significart main effect was obtained for Camp Experience $(F=6.941$, $\mathrm{df}=1 / 56, p<.05)$. Childreir of Concentration Camp Survivors were more hostile than controls (see Appendix XI). 
Assault (Hostility šubscale)

A significant main effect was obtained for Camp Experience $(F=7.963$, $\mathrm{df}=1 / 56, \mathrm{f}<.01)$. Children of Concentration Camp Survivors had a higher mean thán controls on assault (see Appendix XII).

\section{Irritability (Hostility Subscale)}

A marginal Sex $>$ Camp Experience interaction was obtained ( $F=3.241$, $\mathrm{d} f=1 / 56, p<.1)$ (see Appendix XII).

Negativisu (Jostility Subsciale)

A main effect trend was present for Camp Experience $(E=3.777$, $\mathrm{df}=1 / 56, \mathrm{p}(.06)$. Children of Concentraition Camp Survivors vere somewhat more oppositional than controls (see Appendix YII).

Resentment (Hostility Subscale)

A significant main effect was obtained for Canp Experience $(F=5.240$, dif $=1 / 56, p<.05)$. Children of Survivors were more resentful. of others than controls. A marginal Sex $\times$ Camp Experience interaction was obtained $(F=3.459, d f=1 / 56, p<.1)$ (see Appendix XII).

Suspicicn (Hostility Subscale)

A significant main effect was obtained for Camp Experience ( $F=4.52 .4$, $\mathrm{df}=1 / 56, \mathrm{p}<.05)$. Children of Concentration Camp Survivors are more wary and suspicious than controls (see Appendix XII). 
Verbal (Hostility Subscale)

A main effect trend was present for Camp Experience $(F=3.912$, $\mathrm{df}=1 / 56, \mathrm{p}<.06)$. Children of Concentration Canp Survivors expressed somewhat more verbal hostility than controls. (see Appendix XII).

\section{Hypochondriasis}

A significant main effect was obtained for Camp Experience $(F=5.1 .82$, $\mathrm{d} t=1 / 56, \mathrm{p}<.05)$. Children of Concentration Camp Survivors are more hypochondriacal than Controls. A main effect trend was present for Developmental Leve1 $(\mathrm{F}=3.851, \mathrm{df}=1 / 56, \mathrm{p}<.06)$. Children of parents who were Adults curing WW II were somewhat more hypochondriacal than Children of those who were Adolescents during WTV II (see Appendix YI). Anxiety

A Sex $\times$ Camp Experience interaction trend was obtained $(F=3.516$, $\mathrm{df}=1 / 56, \mathrm{p}<.07)$. An investigation of simple effects was conducter by using independert samples t-tests to compare the means for the four groups: Male Children of Survivors, Male Controls, Female Children of Survivors, and Femsle Controls. The tests revealed a significant simple main effect $(y<.05)$ of Camp Experience for Males, but not for Fenales (see Table 20 and Figure 5). Male Children of Survivors are significantly more anxious than Male Controls. In addition, there is a significant simple main effect $(p<.05)$ of Sex for Control subjects, but not for Survivors' Children (see Tatle 21 and Figure 6). Female Controls were significantly more anxious than Male Controls (see Appendix $\mathrm{XI}$ ). 
Table 20

Simple Effects Tests on the Interaction of Camp Experience at Each Level. of Sex for the Deperdent Variable Anxiety

\begin{tabular}{lcrc} 
Camp Experience & Ser & \pm & Probability \\
\hline Across Children & Males & 2.190 & $<.05$ \\
of Survivors & Females & .469 & N.S. \\
and Controls & & \\
\hline
\end{tabular}

Table 21

Simple Effects Tests on the Interaction of Sex at Each Level of Camp Experience for the Dependent Variable Anxiety

\begin{tabular}{clcc} 
Sex & Camp Experience & $t$ & Probability \\
\hline Across Male & Children of Survivors & .505 & N.S. \\
and Female & Controls & 1.988 & $<.05$ \\
\hline
\end{tabular}

Note: d.f. $=30$

$$
\mathrm{n} \text { per cell }=16
$$




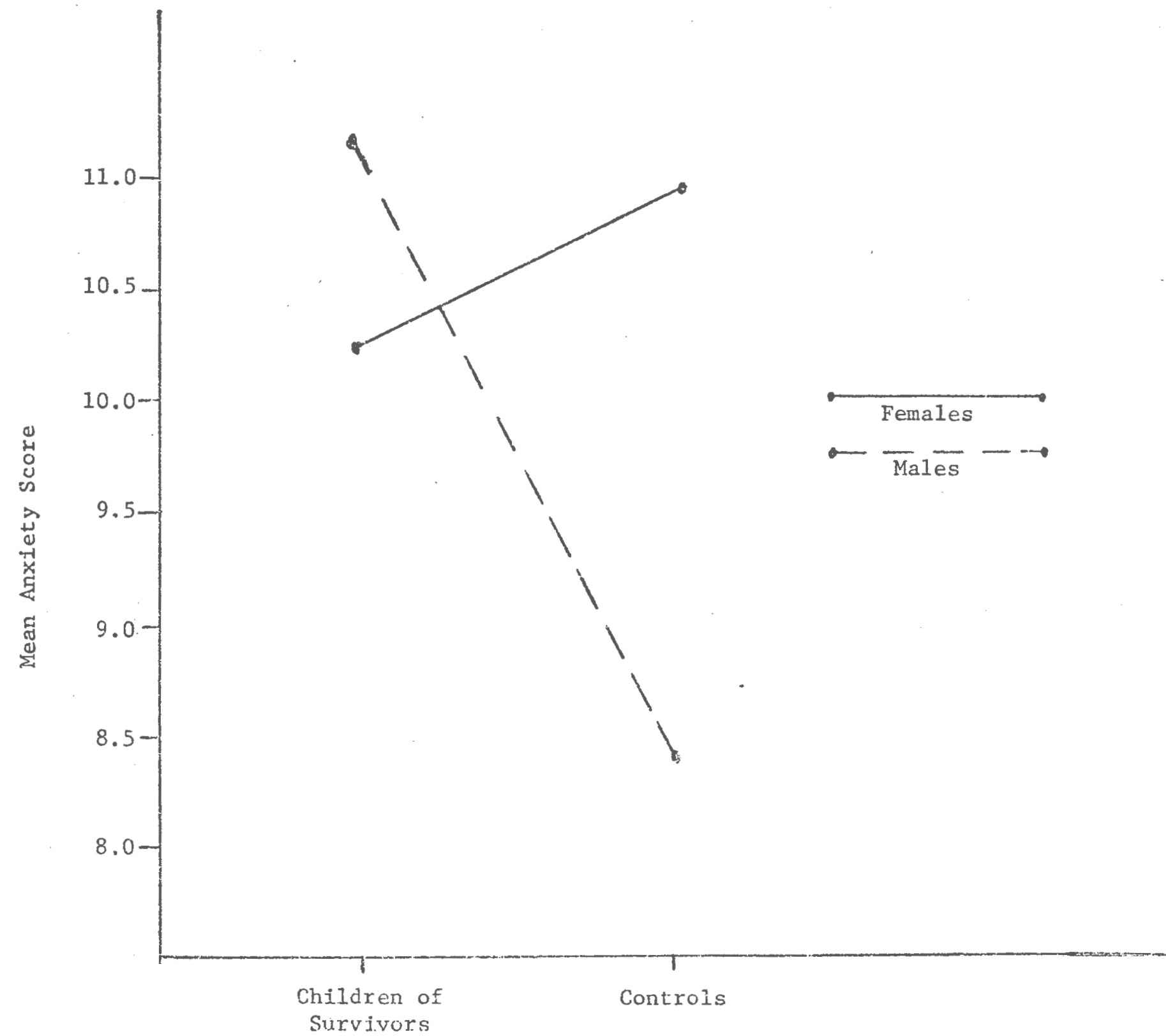

Figure 5. Anxiety scores as a function of Camp Experience and Sex. 


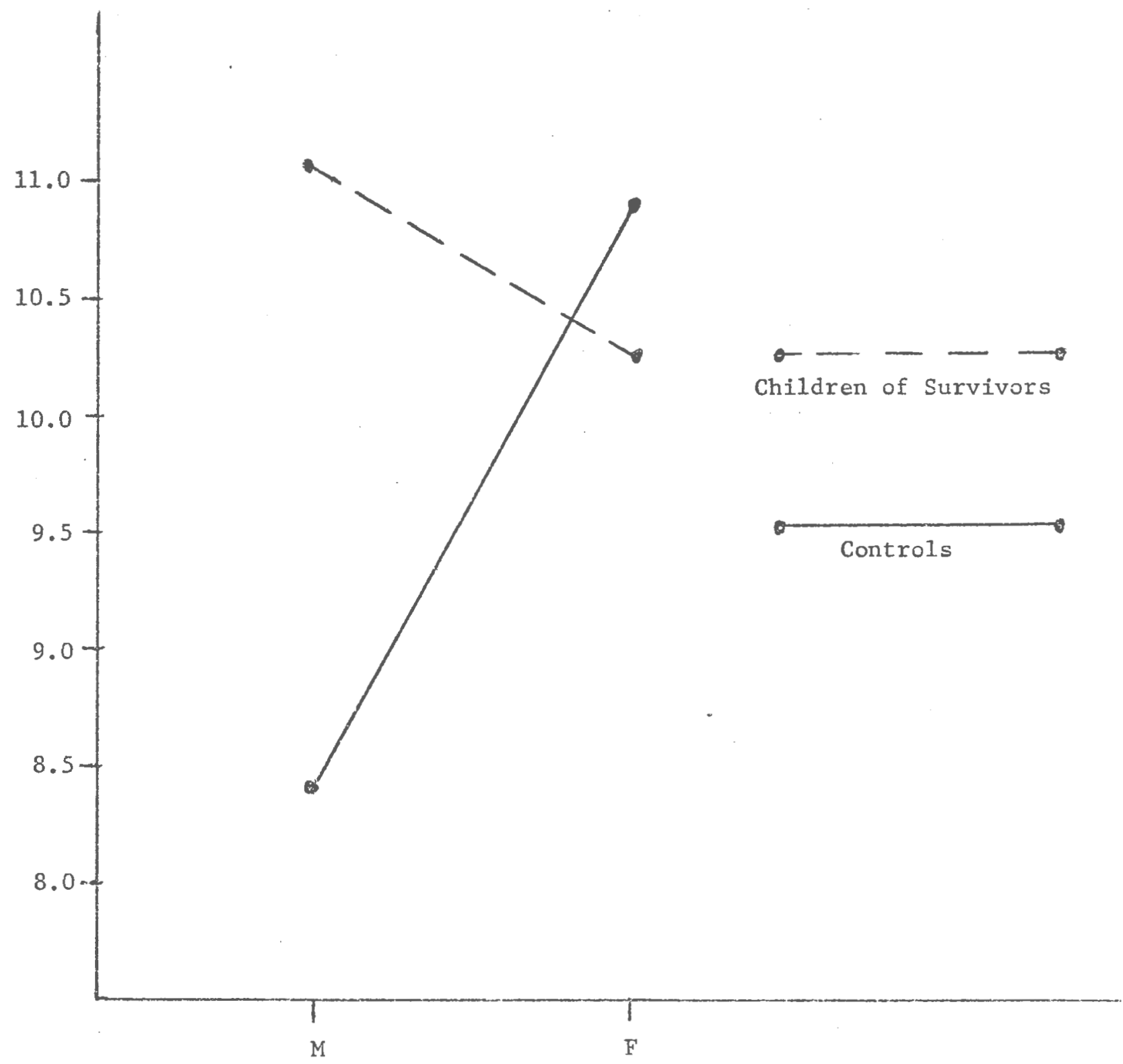

Figure 6. Anxiety scores as a function of Sex and Camp Experience. 


\section{$\underline{\text { Fear }}$}

A Camp Experience $\times$ Developmental Level interaction trend was obtained $(F=2.907$, df $=1 / 56, p<.1)$. An investigation of simple effects was conducted by using independent samples t-tests to compare the means for the four groups: Children of Survivors whose parents were Adults during W II, Coniruls whose parents were Adults during WW II, Children of Survivors whose parents were Adolescents during WW II and Controls whose parents were Adolescents during WW II. The tests revealed a significant simple main effect $(p<.05)$ of Developmental Level for the Survivors' Children, but not for the Controls (see Tables 22 and 23 and Figures 7 and 8 ). Survivors' Children whose parents were Adolescents during WW II were significantly less fearful than Survivors' Children whose parents were Adults during WW II (see Appendix XI).

\section{Table 22}

Simple Effects Tests on the Interaction of Developmenta] Level at Each Level of Carsp Experience for the Dependent Variable Fear

\begin{tabular}{llcc}
$\begin{array}{c}\text { Developmental } \\
\text { Level }\end{array}$ & $\begin{array}{c}\text { Canip } \\
\text { Experience }\end{array}$ & $t$ & Probability \\
\hline $\begin{array}{c}\text { Across } \\
\text { Developmental } \\
\text { Level }\end{array}$ & $\begin{array}{c}\text { Survivors } \\
\text { Controls }\end{array}$ & 1.819 & $<.05$ \\
& .392 & N.S.
\end{tabular}

Note: d.f. $=30$

$n$ per $\operatorname{cel} 1=16$ 
Table 23

Simple Effects Tests on the Interaction of Camp Experience at Each Level of Developmental Level for the Dependent Variable Fear

\begin{tabular}{llll}
$\begin{array}{c}\text { Camp } \\
\text { Experience }\end{array}$ & $\begin{array}{l}\text { Developmentai } \\
\text { Level }\end{array}$ & $t$ & Probability \\
\hline Across Children & $\begin{array}{l}\text { Children of Parents } \\
\text { who were Adults } \\
\text { During WW II } \\
\text { Children of Parents } \\
\text { who were Adolescents } \\
\text { During WN II }\end{array}$ & $\mathbf{1 . 6 7 9}$ & N.S. \\
\hline
\end{tabular}

$$
\begin{aligned}
\text { Note: } & \text { d. } f \cdot=30 \\
& n \text { per } c e 11=16
\end{aligned}
$$

MaIe-Valued (M/F Subscale)

A significant Camp Experience $\times$ Developmental Level interaction was obtained $(F=0.071, \mathrm{df}=1 / 56, \mathrm{p}<.005)$. An investigation of sinple effects was conducted by using independent samples t-tests to compare the means for the four grcups: Children of Survivors whose parents vere Adolescents during WW II, Children of Survivors whose parents vere AduJ.ts during WW II, Controls whose parents were Adolescents during WW II and Controls whose parents were Adults during WW II. The tests revealed significant simple main effects $(p<.05)$ of Camp Experience for both individuals whose parents were Adolescents during Wh II and for individuals whose parents were Adults during WW II, but in different dircctions. Children of Survivors those parents were Adolescents ciring 


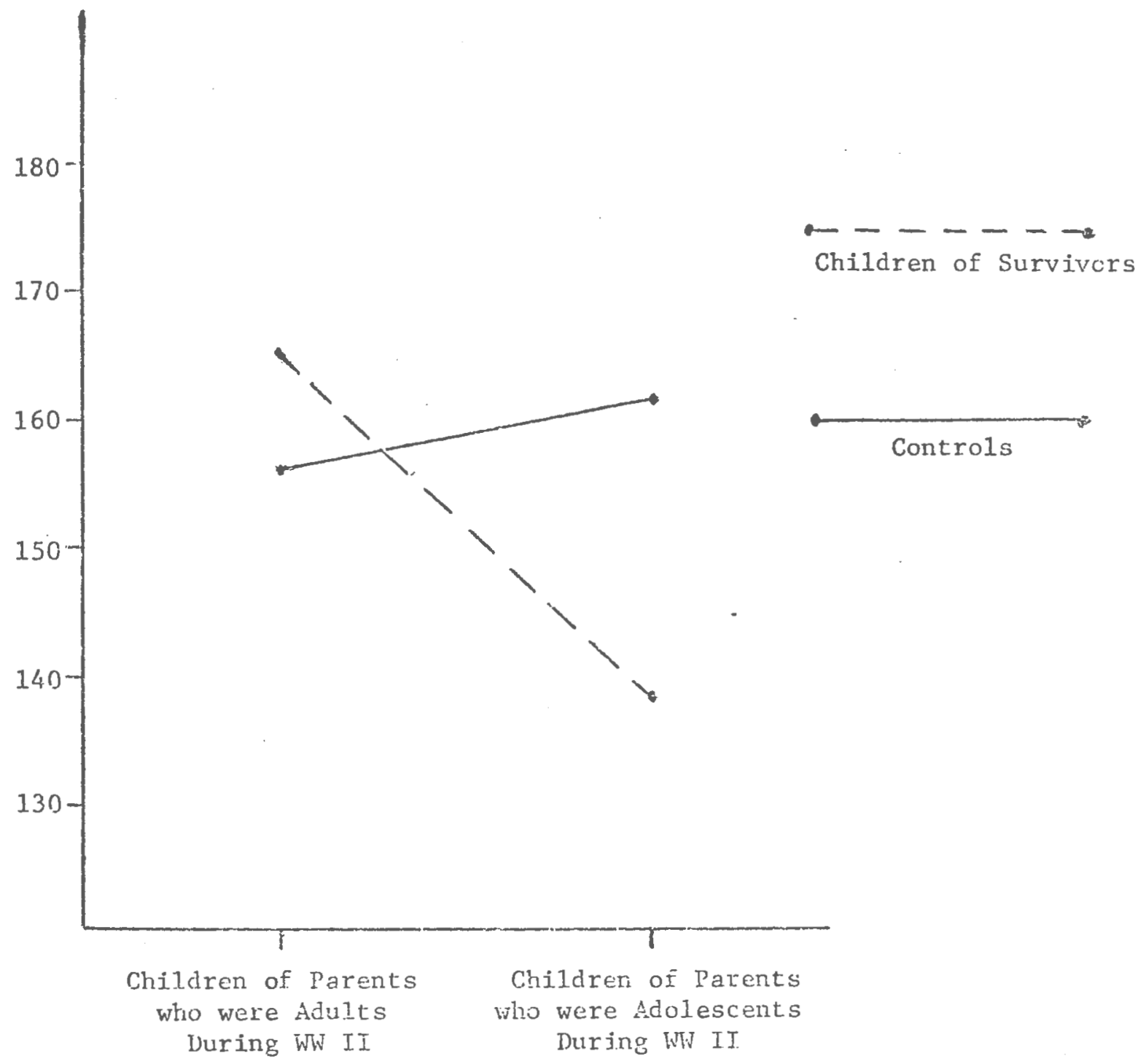

Figure 7. Fear scores as a function of Developmental Level and Camp Experience 
WW II had significantly higher male-valued scores than Controls whose parents were Adolescents during WW II. On the other hand, Children of Survivors whose parents were Adults during WW II had significantly lower male-valued scores than Controls whose parents were Adults during WW II. These results preclude the observation of a main effect for Camp Experience. The t-tests also revealed a significant simple main effect $(p<.005)$ of Developmental Level for Cinildren of Survivors but not for Controls. Children of Survivors whose parents were Adults during WW II have significantly lower male-valued scores than Children of Survivors whose parents were Adolescents during WW II. See Tables 24 and 25 and Figures 9 anci 10.

Tảile 24

Simple Effects Tests on the Interaction of Developmental Ievel at Each Level of Camp Experience for the Dependent Variable Male-Valued (M/F)

\begin{tabular}{llcc} 
Developmertal Level & Cémp Experience & $t$ & Frobability \\
\hline $\begin{array}{l}\text { Across } \\
\text { Developmental } \\
\text { Level }\end{array}$ & $\begin{array}{c}\text { Children of } \\
\text { Survivors } \\
\text { Controls }\end{array}$ & 2.91 & $<.005$ \\
\hline
\end{tabular}

Note: d.f. $=30$

n per $\operatorname{ce} 11=1.6$ 


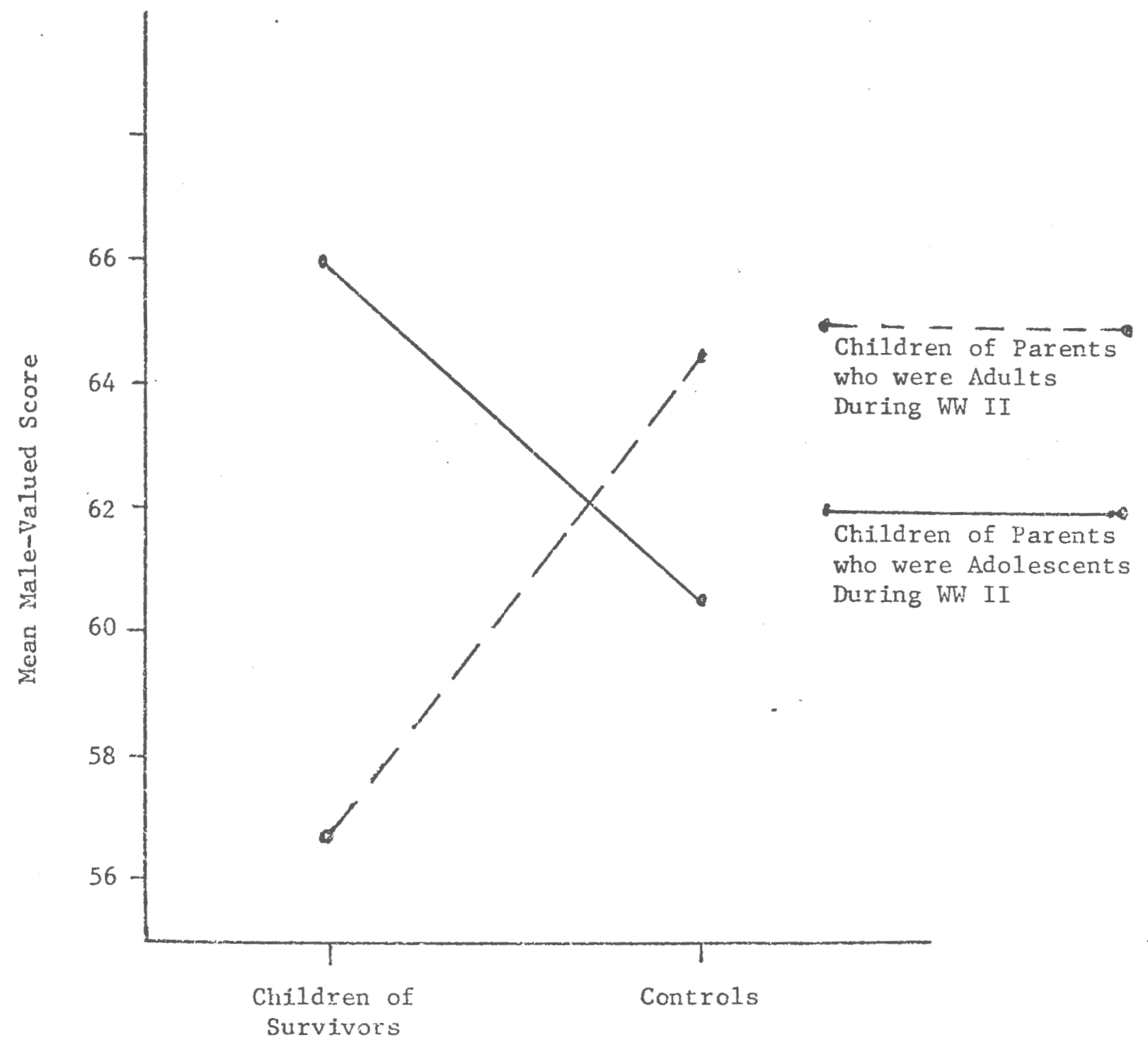

Figure 9. Male-Valued (M/F) scores as a function of Carup Experience and Developmental Jevel 


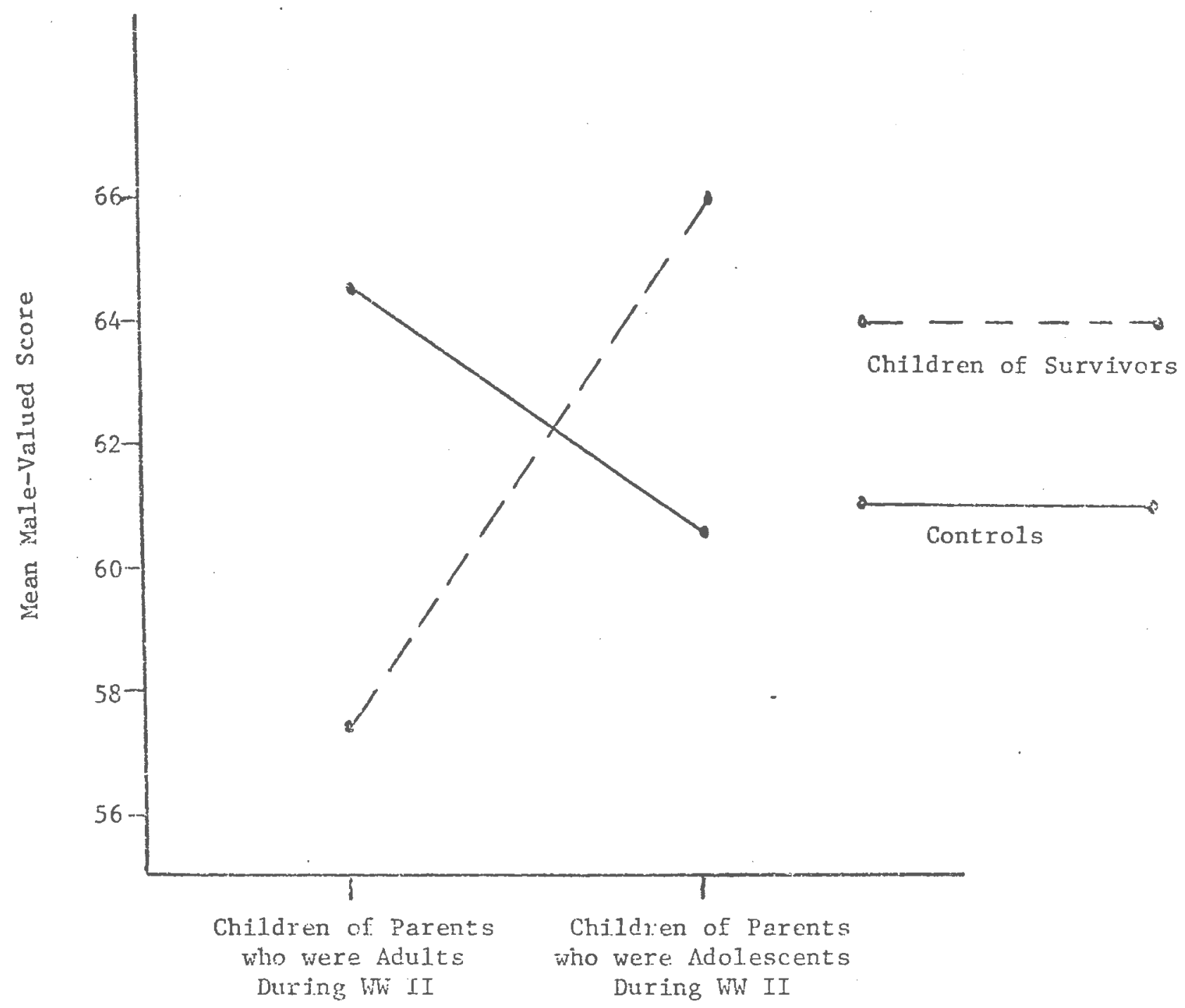

Figure 10. Male-Valued $(M / F)$ scores as a function of Developmental Level and Camp Experience 
Table 25

Simple Effects Tests on the Interaction of Camp Experience at Each Level of Developmental Level for the Dependent Variabie Male-Valued (M/F)

\begin{tabular}{clccc} 
Camp Experience & Developmental Level & $t$ & Probability \\
\hline Across Children & $\begin{array}{l}\text { Children of Parents } \\
\text { who were Adults }\end{array}$ & 2.17 & $<.05$ \\
of Survivors & $\begin{array}{l}\text { During WW II } \\
\text { Children of Parents } \\
\text { who were AdoIescents } \\
\text { During WW II }\end{array}$ & 1.78 & $<.05$ \\
\hline
\end{tabular}

Note: d.f. $=30$

n per $\operatorname{cell}=16$

A significant Sex $\times$ DeveIopmental Level interaction was oitained $(F=4.385, \mathrm{df}=1 / 56, \mathrm{p}<.05)$. An investigation of simple effects was conaucted by using independent samples i-tests to coupare the means for the four groups: Males whose parents were Adolescents during WW II, Males whose parents were Adults during Wh II, Fenales whose parents were Adolescents during WW II and Females whose parents were Adults during WW II. Although there was no main Sex effect, the tests revealed a significant simple main effect $(\mathrm{p}<.05)$ of Sex for individuals whose parents were Adults during WW II. Female children of individuals who were Adults during WW II have a significantly lower mean on malevalued items than Male children of individuals who were Adults during WW II. The t-tests revealed no significant difference between the Males whose parents were Adolescents during WW IJ and Females whose parents were Adolescents during WW II. (There was no simple main sex 
effect for individuais whose parents were adolescents during WW II.) With regard to this result, however, it is worthwhile mentioning that the means obtained on the male-valued items by both the Male and Female children of individuals who were Adolescents during WW II are higher than the means obtained by Spence et a1. for their male and female subjects (see Table 36, page 171). In particular, the mean achieved by the Female children of individuals who were Adolescents during WW II was markedly higher than the mean for i emale subjects obtained by Spence et a1. (see Tabie 36, page 171). This high mean score for Female Children of indiriduals who were Adolescents during WW II explains the abșence of a main effect of sex. See Table 26 and Figure 11.

Table 26

Simple Effects Tests on the Interaction of Sex at Each Ievel of Developmental Level for the Dependent Variable Male-Valued (M/F)

\begin{tabular}{llll} 
Sex & Developmental Level & $t$ & Probability \\
\hline Across & $\begin{array}{l}\text { Children of Parents } \\
\text { Who were Adults } \\
\text { During WW II }\end{array}$ & 2.25 & $<.05$ \\
and & $\begin{array}{l}\text { Children of Parents } \\
\text { who were Adolescents } \\
\text { During WW II }\end{array}$ & .353 & N.S.
\end{tabular}

Note: d.f. $=30$

$\mathrm{n}$ per $\operatorname{ce} 11=16$ 


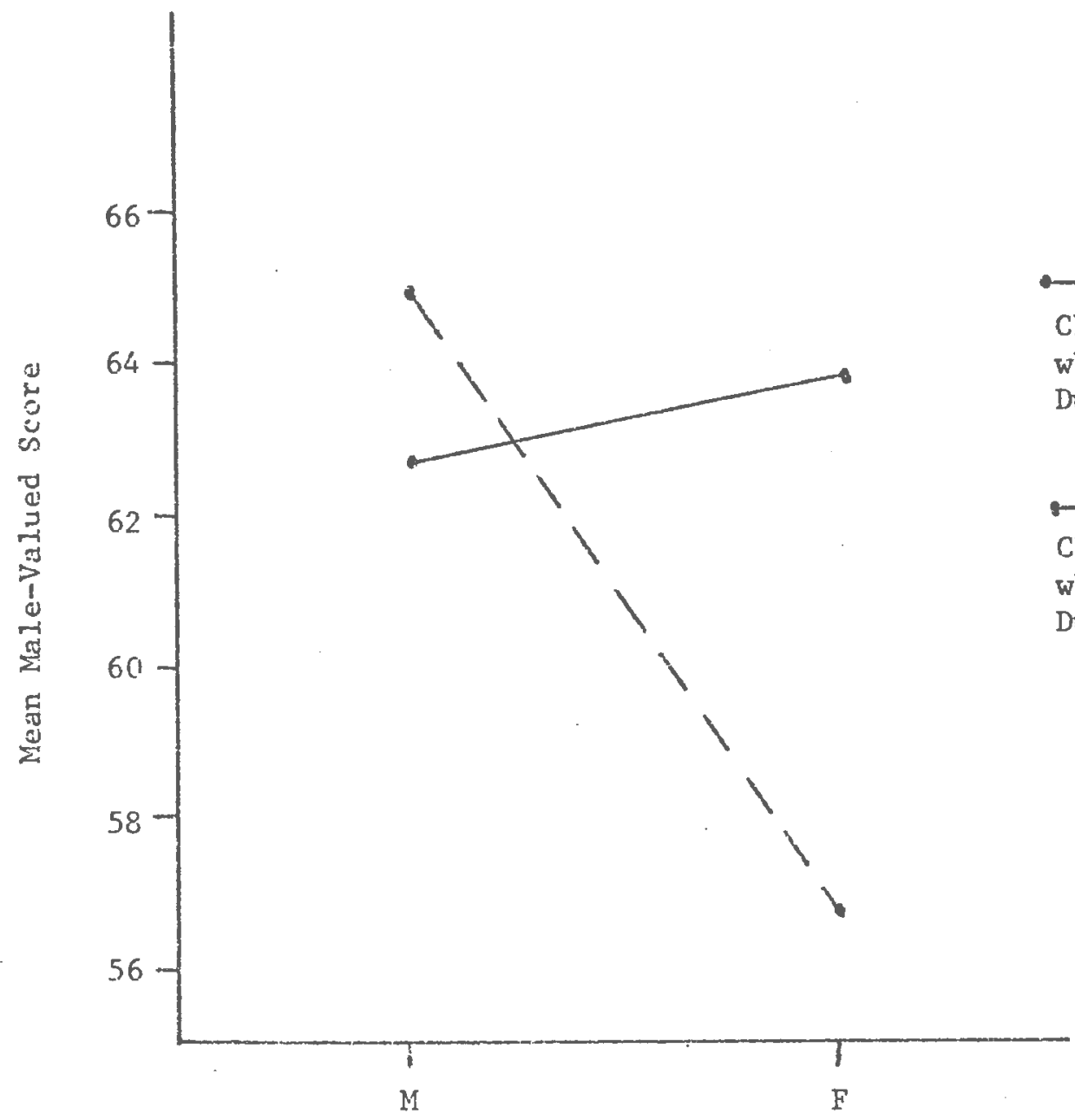

Figure 11. Male-Yalued $(M / F)$ scores as a function of Sex and Developmental Level 
The t-tests also revealed a significant simple main effect ( $p<.05)$ of Developmental Level for Eemales, but not for Males. Female children of Individuals who were Adolescents during WW II have a significantly higher mean on male-valued items than Female children of individuals who were Adults during WW II. See Table 27 and Figure 12.

\section{Table 27}

Simple Effects Tests on the Interaction of Developmental Lavel at Each Level of Sex for the Dependent Variable Male-Valued (M/F)

Developmental Leve1.

Sex $t$ Probability

$\begin{array}{lccc}\text { Across } & \text { Males } & .83 & \text { Ni.s. } \\ \text { Developmental } & \text { Females } & 2.25 & <.05 \\ \text { Level } & & 25\end{array}$

Note: d.f. $=30$

$n$ per cell $=16$

The means for Males whose parents were Adolescents during WW II, Males whose parents were Adults during WW II and Females whose parents were Adolescents during WW II are all similar to each other and high compared to the means obtained by Spence-Helmreich (see Table 36, page 171). The mean of the Females whose parents were Adilts during WW II, on the other hand, was considerably lower than the means for the other three groups, and even below the mean for females on maie-valied items obtained by Spence-Helmreich (see Table 36 and Appendix XIII). 


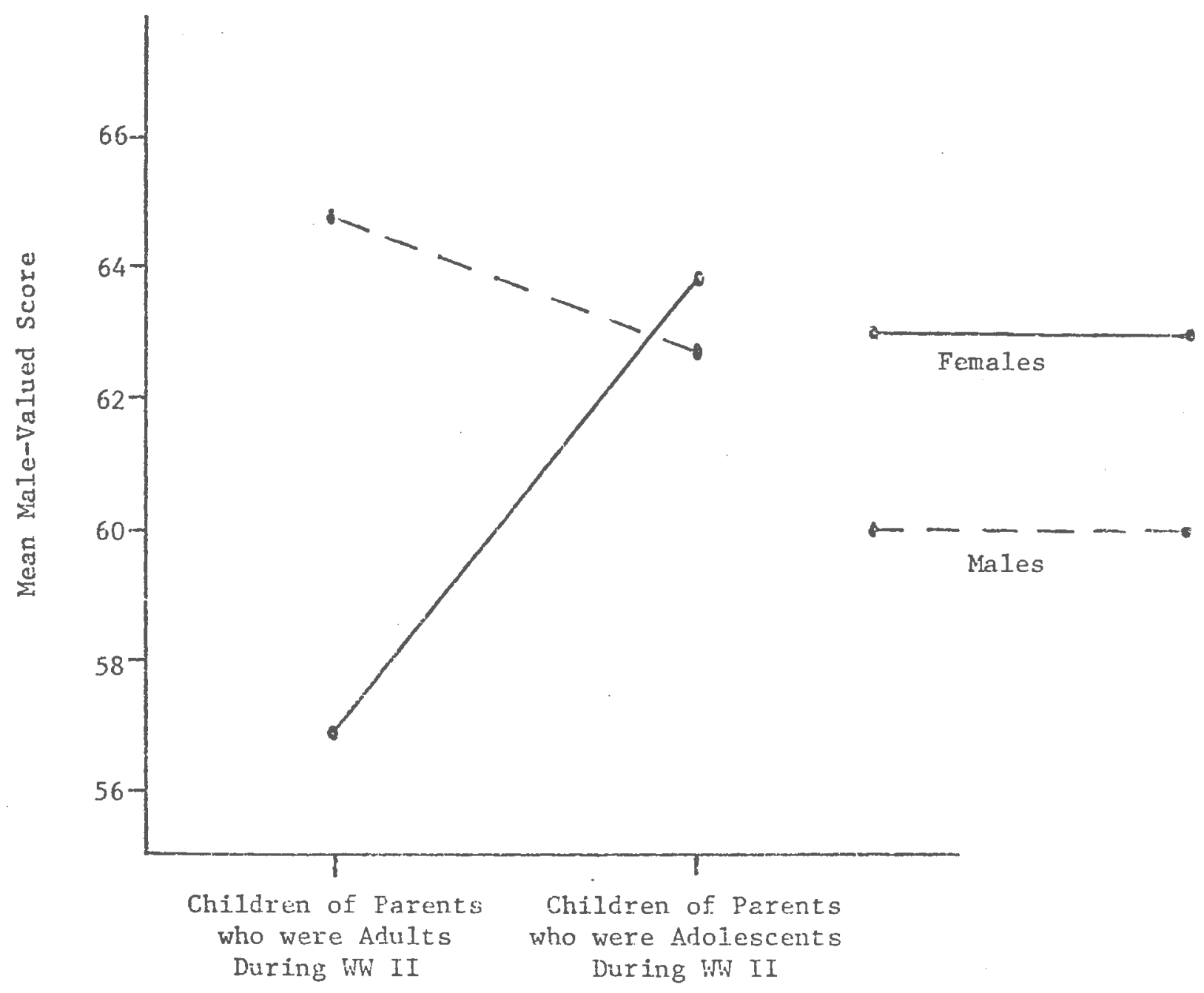

Figure 12. Male-Valued (M/E) scores as a function of Developnental Ievel and Sex 
Fenale-Valued ( $(4 / F$ Subscale)

A significant main effact was obtained for Sex $(F=6.799, \mathrm{df}=1 / 56$, $\mathrm{p}<.05)$. Males had a higher mean than Females on female-valued items (see Appendix XIII).

\section{Sex-Sfecific (M/F Subscale)}

A significant main effect was obtained for $\operatorname{Sex}(F=9.788, \mathrm{~d} f=1 / 56$, $p<.005)$. Males had a higher mean than Females on sex-specific items.

A main effect trend was present for Developmental Level $(F=3.309$, $d f=1 / 56, p<.1)$. Children of individuals who were Adolescents during WW II had a marginaily higher mean than Children of individuals who were Adults during WW II.

A significant Developmenta1 Level $\times$ Camp Experience interaction was obtained on the sex-specific itens of the PAR $\left(F=4.452, \mathrm{~d}_{1}=1 / 56\right.$, $p<.05)$. This is extremely difficult to conceptualize since the test measures the individual's conception of the ideal male and ideal female on a bipolar scale, and to analyze the interaction effect, we must collapse over sex. To gain insight into the meaning of the interaction effect, the means are compared for each sex separateiy (see Tables 28, 29, 30, 31 and Eigures 13, 14, 15, 16). Independent samples t-tests revealed that the mean for Male Children of Survivors whose parants were Adults during WW II was considerably lowex than any other Male group (i.e., these subjects tended to see the ideal male as possessing more stereotypically feminine characteristics). For example, the simple main effect of Developmental Level. for the Male Children of Survivors was significant at the .05 level, while the simple main 
Table 28

Simple Effects Tests on the Interaction of

Developmental Level at Each Level of Camp Experience

for the Dependent Variable Sex-Specific (M/F). Females only.

\begin{tabular}{lccc} 
Developmental Level & Camp Experience & $t$ & Probability \\
\hline $\begin{array}{l}\text { Across } \\
\text { Developmental } \\
\text { Level }\end{array}$ & $\begin{array}{c}\text { Children of } \\
\text { Survivors } \\
\text { Controls }\end{array}$ & 1.67 & N.S. \\
\hline
\end{tabular}

Note: d.f. $=14$

$\mathrm{n}$ per $\operatorname{cell}=8$

Table 29

Simple Effects Tests on the Interaction of

Camp Experience at Each Level of Developmental Level for

the Dependent Variable Sex-Specific $(M i F)$. Females OnIy.

\begin{tabular}{llll} 
Camp Experience & Developmental Level & t & Probability \\
\hline Across & $\begin{array}{l}\text { Children of Parents } \\
\text { who were Adults } \\
\text { Children of }\end{array}$ & During WJ II \\
Survivors & $\begin{array}{l}\text { Children of Parents } \\
\text { who were Adolescents } \\
\text { During WW II }\end{array}$ & .51 & N.S. \\
& Dontrols & N.S.
\end{tabular}

Note: d.f. $=14$

$n$ per $\operatorname{cell}=8$ 
Table 30

Simple Effects Tests on the Interaction of Developmental Level at Each Level of Camp Experience for the Dependent Variable Sex-Specific $(M / F)$. Males Only.

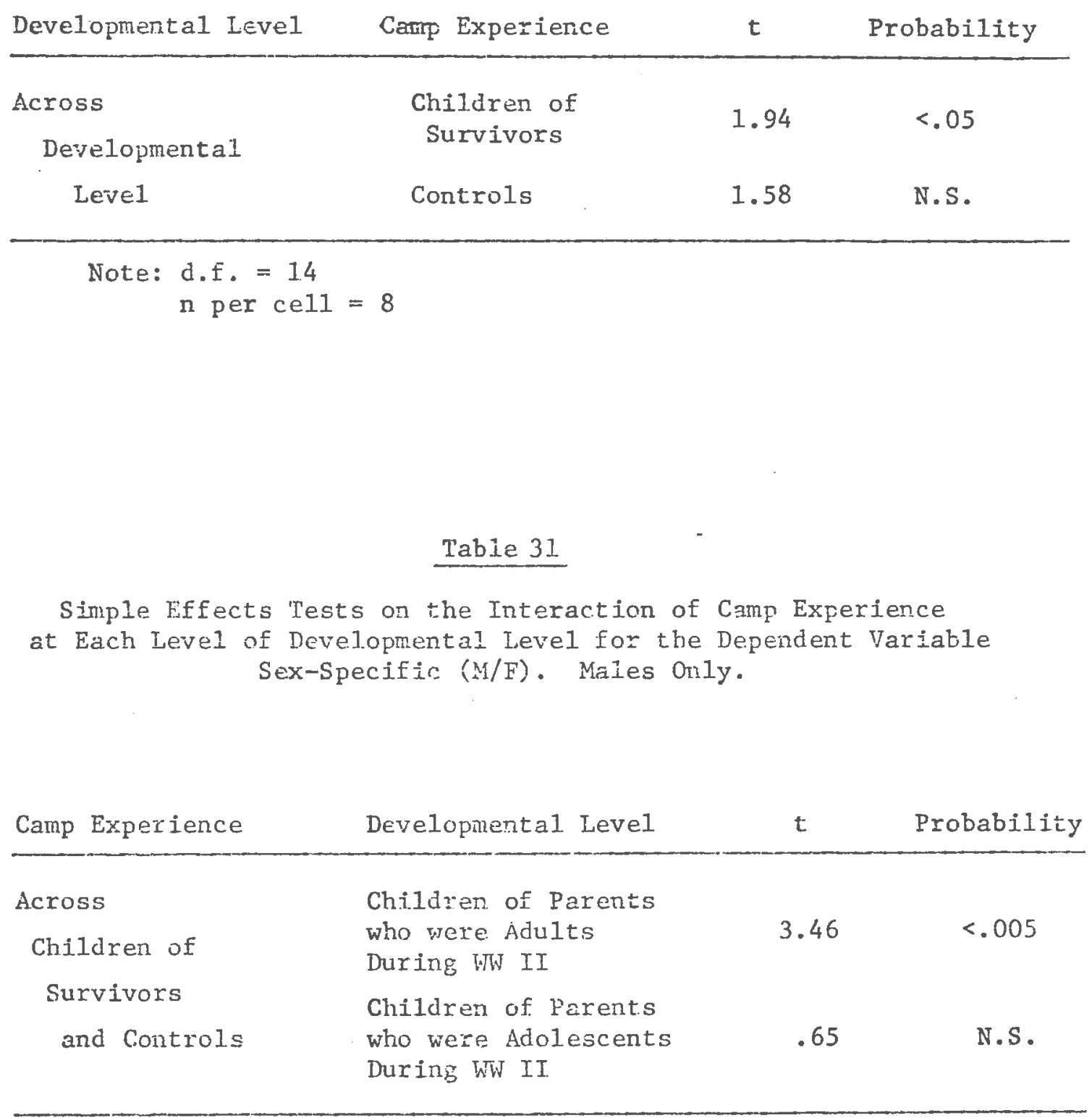

Note: d.f. $=14$

$n$ per $\operatorname{cel1}=8$ 


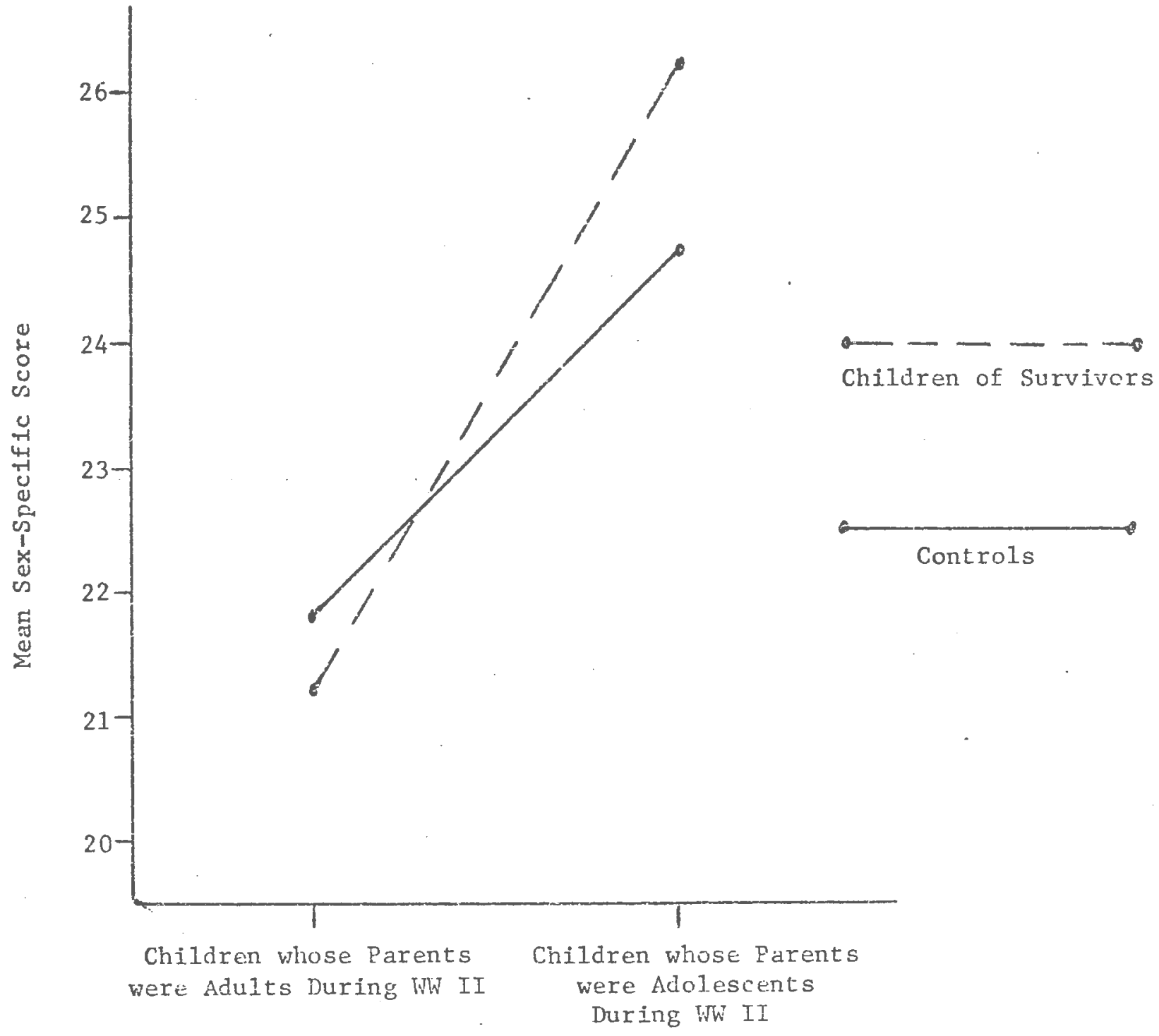

Figure 13. Sex-Specific (M/E) scores as a function of Developmental Level and Camp Experience.

Females oniy. 


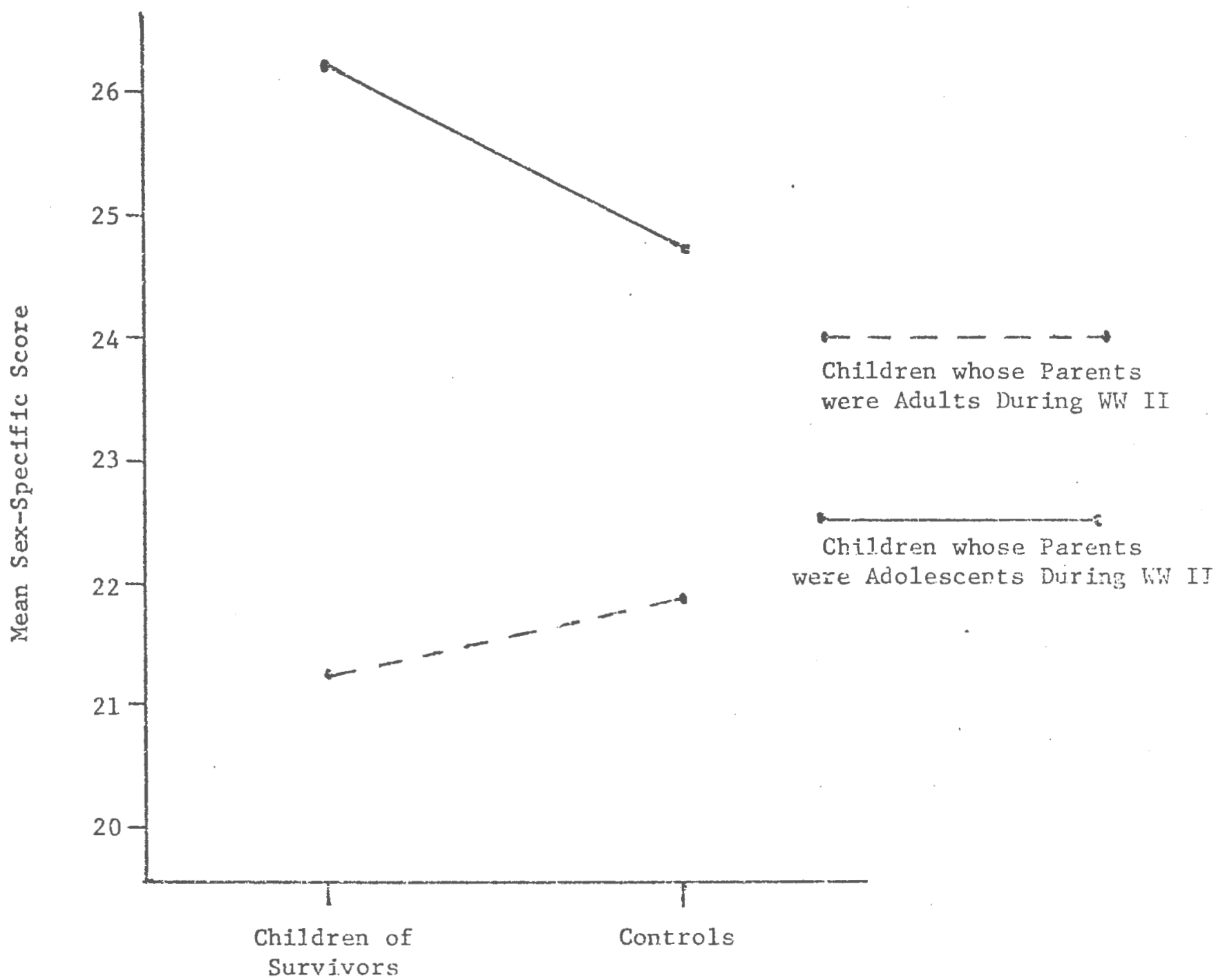

Figure 14. Ser-Specific $(M / F)$ scores as a function of Camp Expericnce and Developmental Level. Fenales only. 


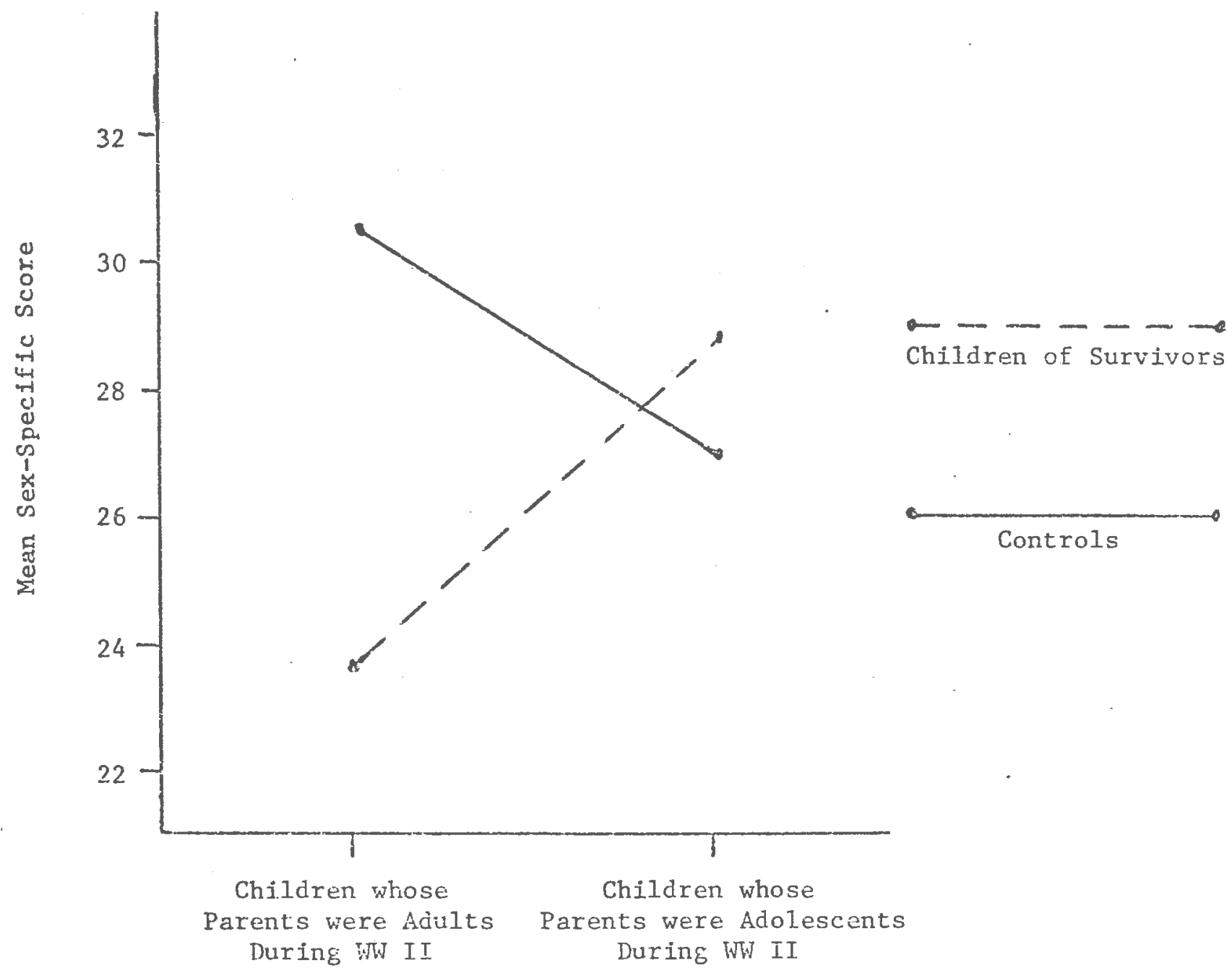

Figure 15. Sex-Specific $(\mathrm{M} / \mathrm{F})$ scores as a function of Developmental Level and Camp Experience. Males only. 


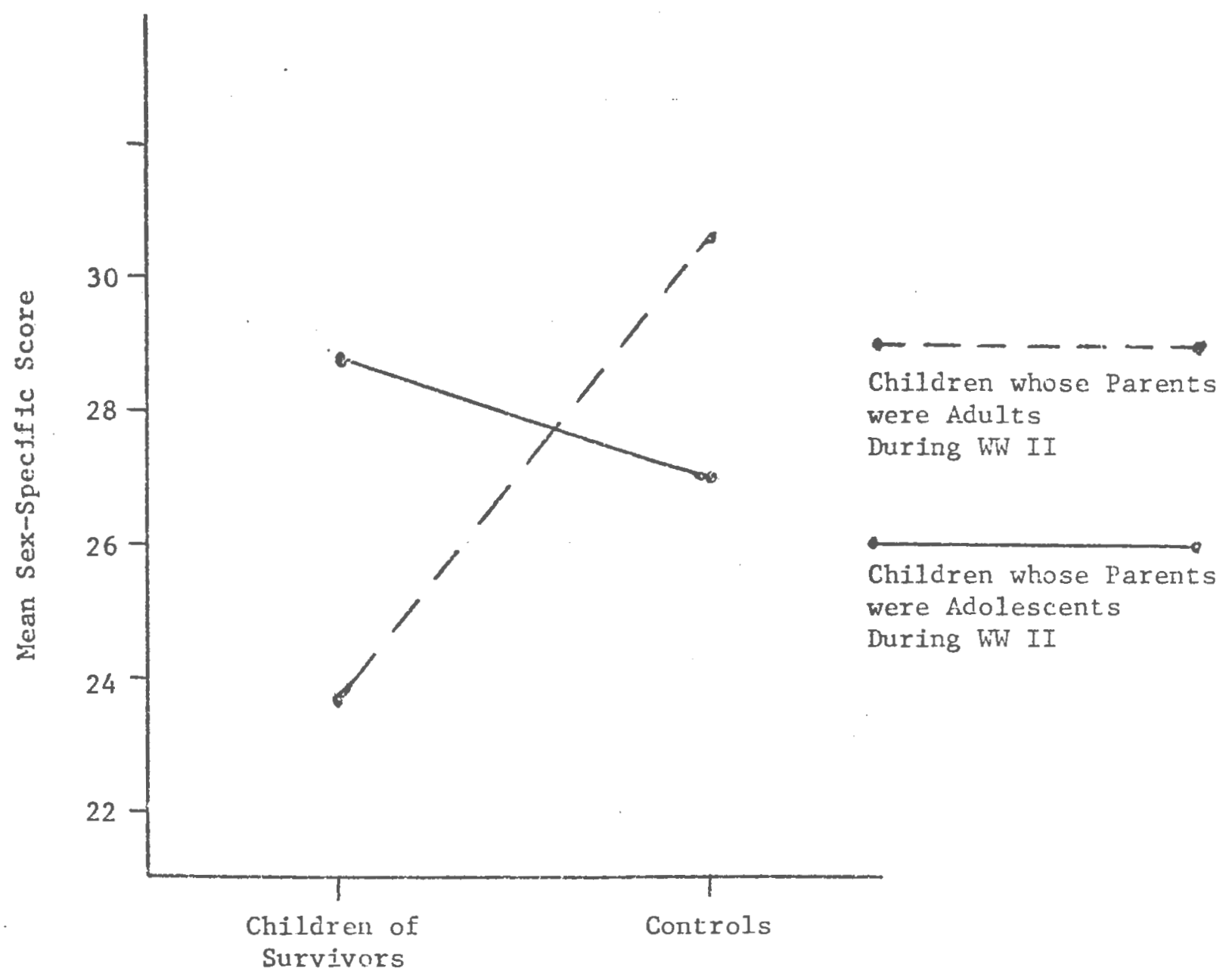

Figure 16. Sex-Specific $(M / F)$ scores as a function of Camp Experience and Developmental Level. Males only. 
effect of Camp Experience for the Male Children of Individuals who were Adults during WW II was significant at the .005 level. The mean for the Male Children of Survivors who were Adults during WW II, combined with the somewhat lower mean for the Female Children of Survivors who were Adults during WW II, produces the low mean for the group of Children of Survivors whose parents were Adults during WW II when it is collapsed over sex.

The final independent samples t-tests were used to investigate the primary Camp Experience $\times$ Developmental Level interaction (see Tables 32,33 and Figures 17, 18). An exploration of simple effects was conducted to compare the means for the four groups: Children of Survivors whose parents were Adolescents during. WW II, Children of Survivors whase parents were Adults during WW II, Controls whose parents were Adolescents during WW II and Controls whose parents were Adults during WW II. The tests revealed a significant simple main effect $(p<.05)$ of Camp Experience for individuals whose parents were Adults during WW II, but not for individuals whose parents were Adolescents during VW II. Children of Survivors whose parents were Adults during WiN II had significantly lower sex-specific scores than Controls whose parents were Adults during Wh II. In addition, the t-tests revealed a simpie main effect $(p<.005)$ of Developmental Level for Children of Survivors, but not for Controls. Children of Survivors whose parents were Adolescents during WW II had significantly higher sex-specific scores than Children of Survivors whose parents were Adults during Wh II.

The means on the sex-specific items for Children of Survivors whose parents were Adolescents during WW II, Controls whose parents were Adolescents during WW II and Controis whose parents were Adults 
Table 32

Simple Effects Tests on the Interaction of Developmental Level at Each Level of Camp Experience for the Dependent Variable Sex-Specific $(M / F)$. Males and Females.

\begin{tabular}{lccc} 
Developinental Level & Camp Experience & $t$ & Probability \\
\hline $\begin{array}{c}\text { Across } \\
\text { Developmental } \\
\text { Level }\end{array}$ & $\begin{array}{c}\text { Children of } \\
\text { Survivors } \\
\text { Controls }\end{array}$ & 2.76 & $<.005$ \\
\hline
\end{tabular}

$\begin{aligned} \text { Note: } & \text { d.f. }=30 \\ & \text { n per } \operatorname{cell}=16\end{aligned}$

Table 33

Simple Effects Tests on the Interaction of

Camp Experience at Each Level of Developmental Levei for the Dependent Variable Sex-Specific $(M / F)$. Males and Females.

\begin{tabular}{|c|c|c|c|}
\hline Camp Experience & Developmertal Level & $t$ & Probability \\
\hline $\begin{array}{l}\text { Across } \\
\text { Children of }\end{array}$ & $\begin{array}{l}\text { Children of Parents } \\
\text { who were Adults } \\
\text { During Wh II }\end{array}$ & ]. .83 & $<.05$ \\
\hline $\begin{array}{l}\text { Survivors } \\
\text { and Controls }\end{array}$ & $\begin{array}{l}\text { Children of Parents } \\
\text { who were Adolescents } \\
\text { During Ww II }\end{array}$ & .923 & R.S. \\
\hline
\end{tabular}

Note: d.f. $=30$

$\mathrm{n}$ per $\operatorname{cell}=16$ 


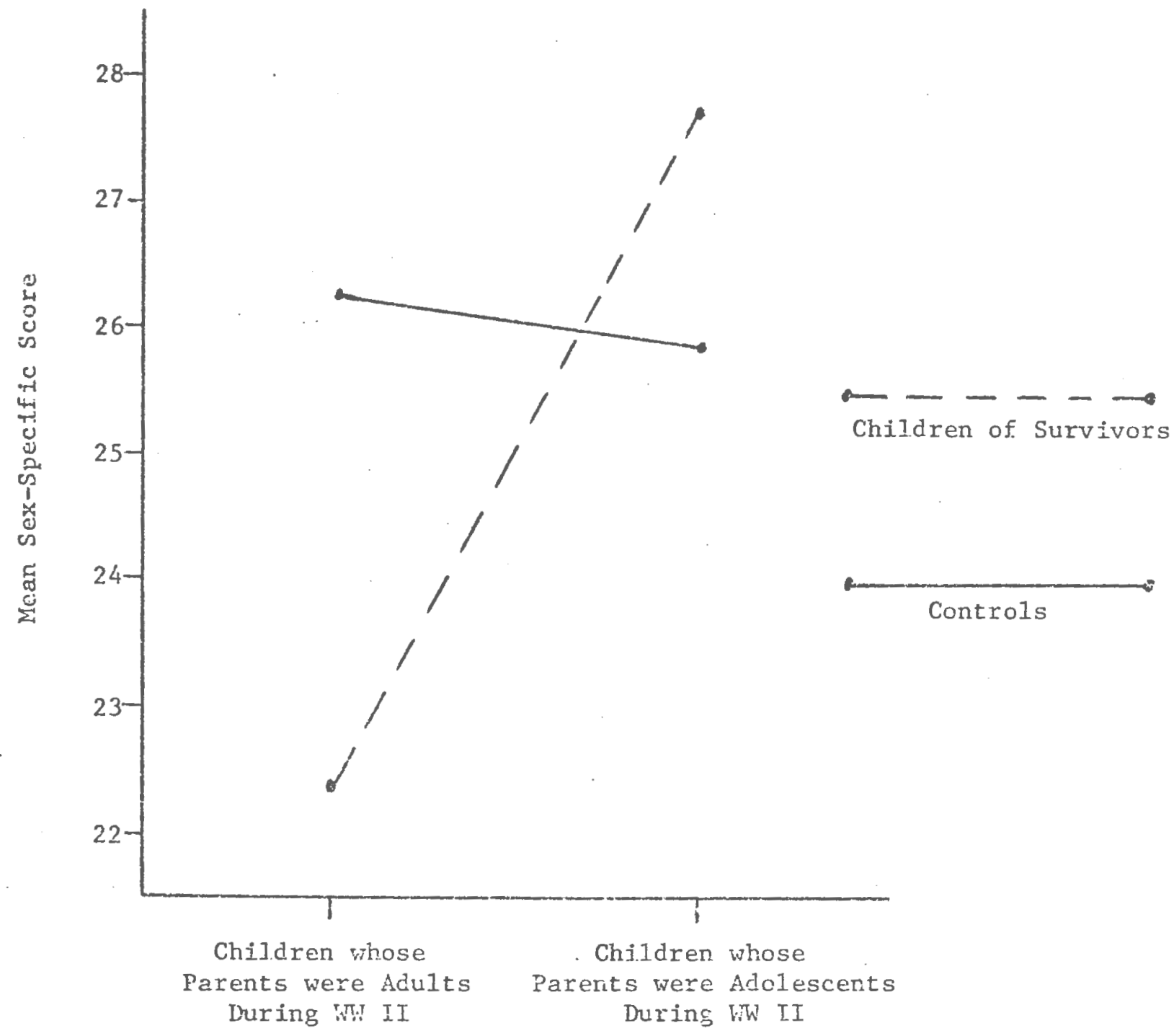

Figure 17. Sex-Specific (M/F) scures as a function of Developmental Level and Carip Experience. Males and Females. 


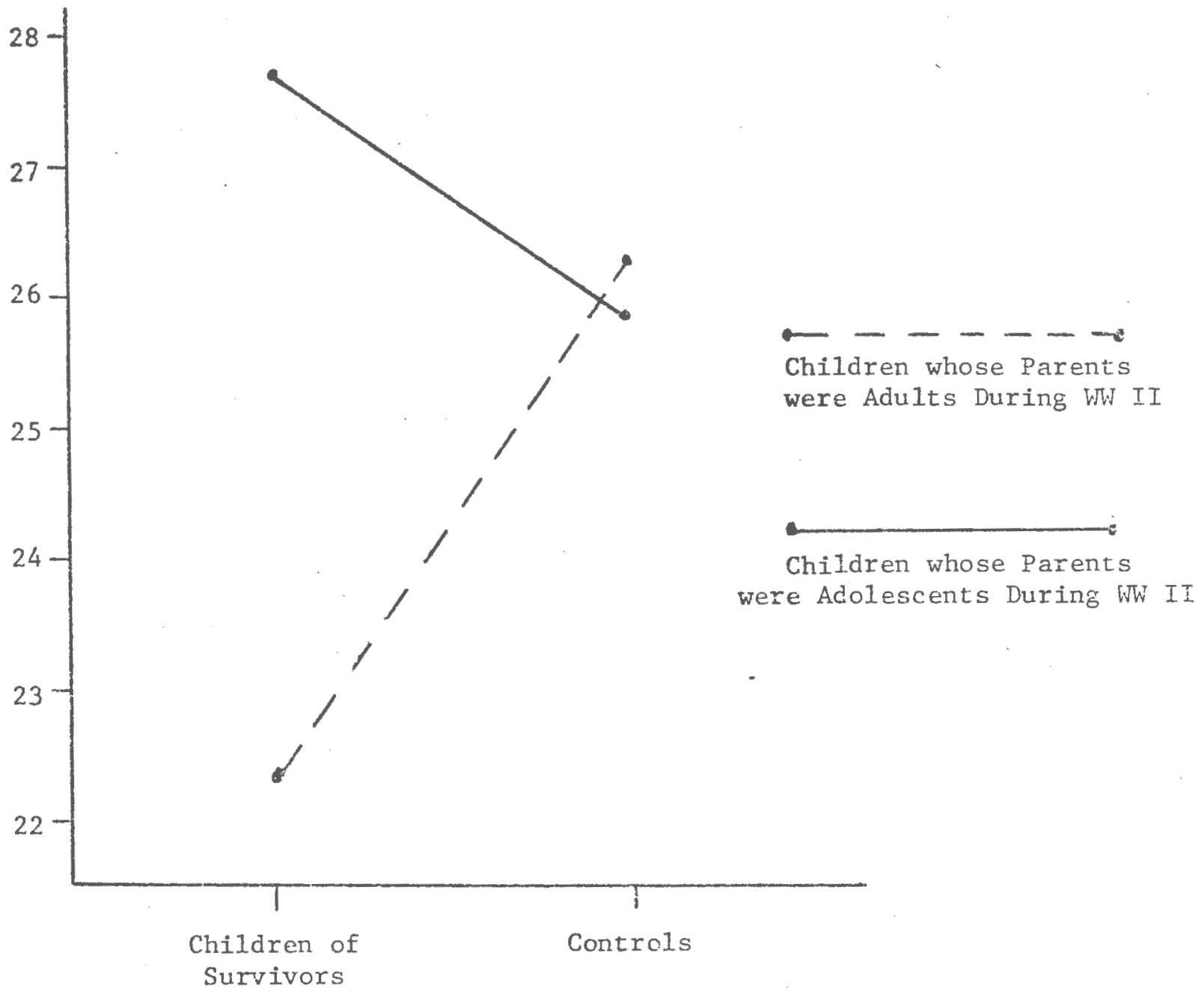

Figure 18. Sex-Specific (M/F) scores as a function of Camp Experience and Developmental Level. Males and Females. 
during Wi II are all similar to each other. The mean on the sexspecific items for the Children of Survivors whose parents were Adults during WW II, en the other hand, was considerably lower than the means for the other three groups, and resembled the mean obtained by Spence et al. For their female subjects on the sex-specific items. The marginal main effect of Developmental Level, in fact, was obtained as a result of this exceptionaily low mean on the sex-specific items for the Children of Survivors whose parents were Adults during WW II (see Appendix XIII) . 


\section{DEPENDENT VARIARLES EXAMINED BY STRUCTURED INTERVTSW}

\section{Alienation}

A main effect trend was present for Camp Experience $(F=3.063$, $\mathrm{df}=1 / 56, \mathrm{p}<.1)$. Children of Concentration Camp Survivors were marginally more alienated than Controls. A marginal Sex $\times$ Developmental Level interaction was also obtained $(F=3.403, \mathrm{df}=1 / 56, \mathrm{p}<.1$ ) (see Appendix XIV).

\section{Anomie (Alienation Subscale)}

A main effect trend was present for Camp Experience ( $F=3.936$, $\mathrm{d} f=1 / 56, \mathrm{p}<.05)$. Children of Concentration Camp Survivors experience somewhat more normlessness than Controls (see Appendix XIV).

\section{Powerlessness (Alienation Subscale)}

A significant main effect was obtained for Developmental LEvel $(F=6.384, \mathrm{df}=1 / 56, \bar{p}<.05)$. Children of Parents who were Adults during WW II feel wore powerless than Children of Parents who were Adolescents during WW II. A significant Sex $\times$ Developmental Level interaction was also obtained $(\mathrm{F}=4.967, \mathrm{df}=1 / 56, \mathrm{~F}<.05$ ) (see Appendix XIV).

\section{Trust}

A significant main effect was obtained for Camp Experience $(F=5.361, \mathrm{df}=1 / 56, \mathrm{f}<.05)$. Children of Concentration Camp Survivors were less trusting than Controls. A Sex $\times$ Camp Experience interaction trend was also obtained $(F=3.879, \mathrm{df}=1 / 56, \mathrm{p}<.06)$. An investiga- 
tion of simple effects was conducted by using independent samples t-tests to compare the means for the four groups: Male Children of Survivors, Male Controls, Female Chiluren of Survivors, and Female Controls. The tests revealed a significant main effect $(p<.005)$ of Camp Experience for Males, but not for Females (see Table 3it and Eigure 19). Male Children of Survivors are significantly less trusting than Male Controls. In addition; there is a simple main effect $(p<.05)$ of Sex for Control subjects, but not for Survivors' Children (see Table 35 and Figure 20). Male Controls are significantly more trusting than Female Controls (see Appendix XIV). 


\section{Table 34}

Simple Effects Tests on the Interaction of Camp Experience at Each Level of Sex for the Dependent Variable Trust

\begin{tabular}{lccc} 
Camp Experience & Sex & $t$ & Probability \\
\hline Across Children & Males & 3.3419 & $<.005$ \\
of Survivors & Females & .23 & N.S. \\
and Controls & & & \\
\hline
\end{tabular}

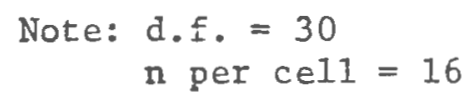

Table 35

Simple Effects Tests on the Interaction of Sex at Each Level of Camp Experience for tỉe Dependent Variable Trust

\begin{tabular}{cccc} 
Sex & Camp Experience & t & Probability \\
\hline Across Male & Children of Survivors & .449 & N.S. \\
and Female & Controls & 2.286 & $\therefore .05$ \\
\hline
\end{tabular}

Note: d.f. $=30$

n per $\operatorname{cel} 1=16$ 


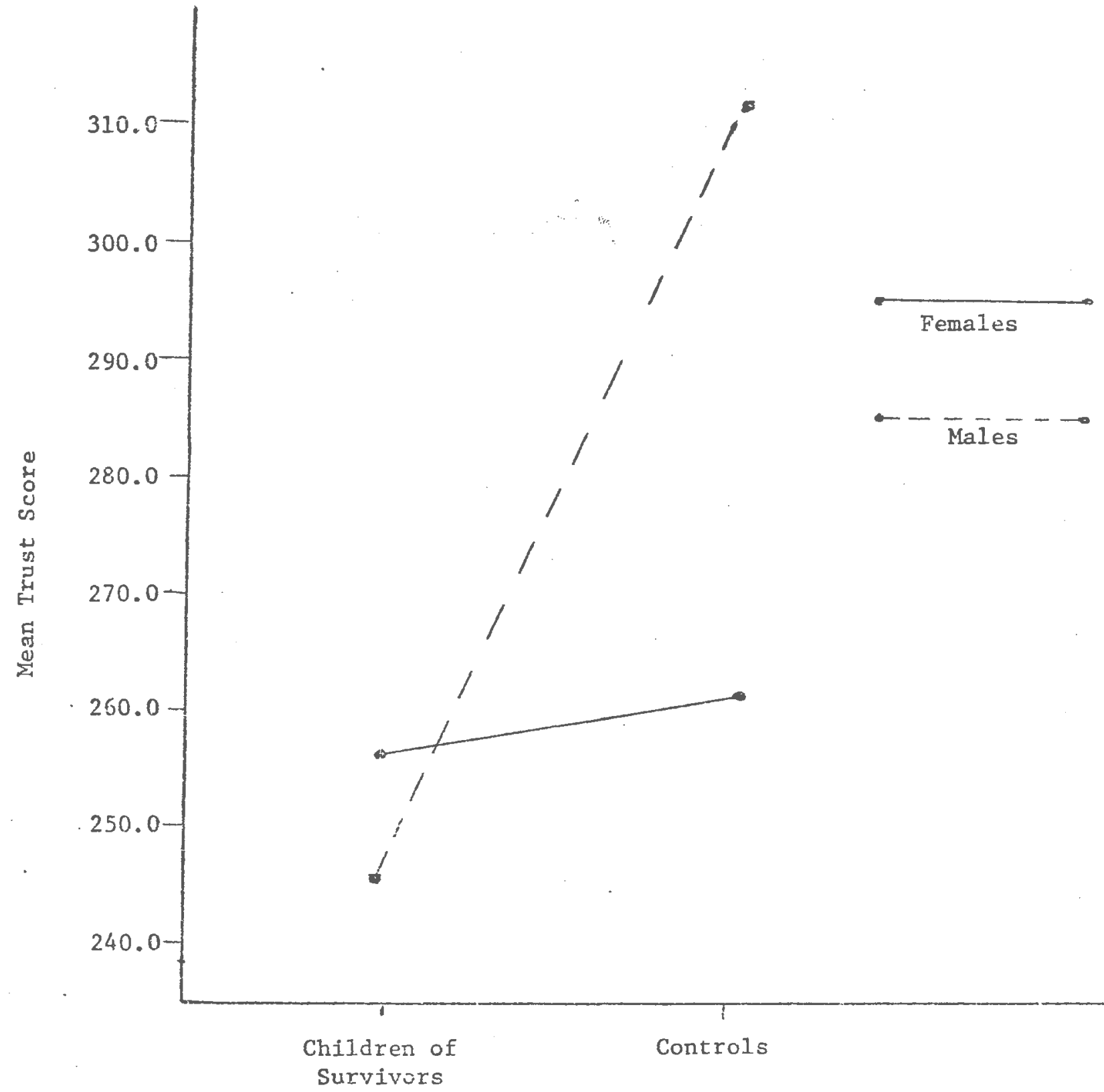

Figure 19. Trust scores as a function of Camp Experience and Sex. 


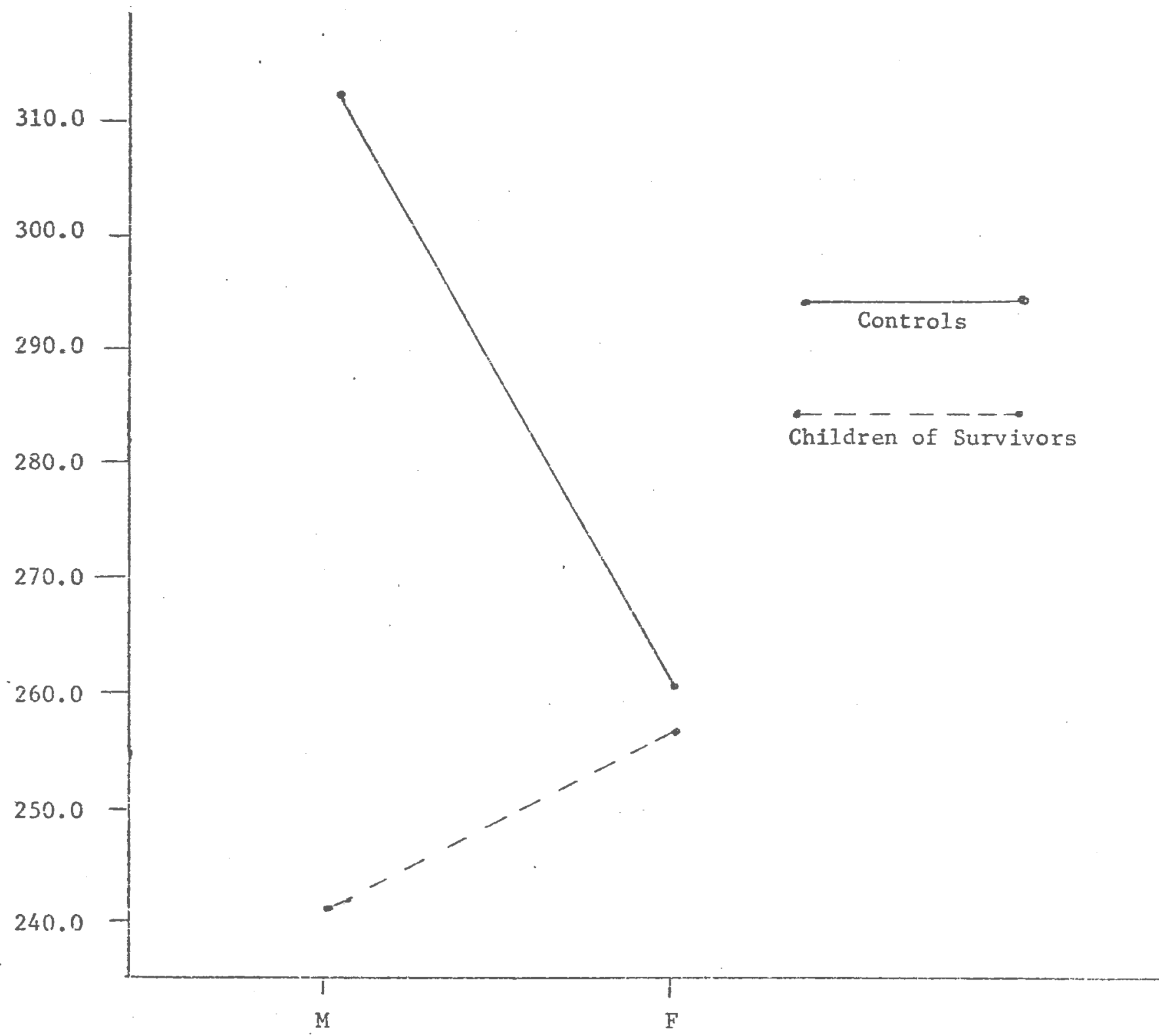

Figure 20. Trust scores as a function of Sex and Camp Experience. 
Tehle 35

Norinative Dita for Scales Compaleite the Pdi (lersonal attributes Inventoly)

\begin{tabular}{|c|c|c|c|c|c|}
\hline \multirow{2}{*}{ Dependeut Variable } & \multirow{2}{*}{ Scala } & \multicolumn{2}{|c|}{ Males } & \multicolumn{2}{|c|}{ Fentales } \\
\hline & & $\bar{x}$ & S.D. & $\bar{x}$ & S.D. \\
\hline Abasemot & $\begin{array}{l}\text { lackson's PhF } \\
\text { (Form AA) }\end{array}$ & 6.22 & 2.92 & 7.27 & 3.07 \\
\hline Aut onomy & $\begin{array}{l}\text { Jackson's PRF } \\
\text { (Form } \Lambda A \text { ) }\end{array}$ & 8.62 & 3.12 & 7.08 & 3.43 \\
\hline Succorance & $\begin{array}{l}\text { Jackson's PRF } \\
\text { (Enrm AA) }\end{array}$ & 7.88 & 3.50 & 11.19 & 4.23 \\
\hline Anxiety & $\begin{array}{l}\text { Jazkson Paison- } \\
\text { ality Inventory }\end{array}$ & 10.38 & 4.43 & 12.42 & 4.24 \\
\hline Innovation & $\begin{array}{l}\text { Jackson Persen- } \\
\text { elity Iriventory }\end{array}$ & 13.09 & 4.48 & 11.68 & 5.21 \\
\hline Interfersonal Affect & $\begin{array}{l}\text { Jackson Person- } \\
\text { alıty Inventory }\end{array}$ & 10.97 & 4.35 & 13.71 & 4.02 \\
\hline Fear & $\begin{array}{l}\text { Geer Fear Survey } \\
\text { Schedule(ESS-II) }\end{array}$ & 75.78 & 33.84 & 100.16 & 36.11 \\
\hline Nale-Valued & $\begin{array}{l}\text { Spence-lielarcich- } \\
\text { Stapp PAQ }\end{array}$ & 50.51 & 20.39 & 57.73 & 10.87 \\
\hline Female-Vained & $\begin{array}{l}\text { Spcnce-Helnreich- } \\
\text { Stapp laq }\end{array}$ & 23.27 & 7.60 & 18.85 & 6.55 \\
\hline Sex-Specific & $\begin{array}{l}\text { Spence-He Inreich- } \\
\text { SLARp IAl }\end{array}$ & 27.21 & 5.24 & 22.34 & 5.66 \\
\hline Total ilosility & $\begin{array}{l}\text { Buss-Durkee } \\
\text { Hostility-Guilt } \\
\text { Inventory }\end{array}$ & 30.87 & 10.24 & 27.74 & 8.75 \\
\hline Assault & $\begin{array}{l}\text { Buss-Dirkae } \\
\text { Hostility-C-u1lt } \\
\text { Inventory }\end{array}$ & 5.37 & 2.48 & 3.27 & 2.31 \\
\hline Indirect Hostility & $\begin{array}{l}\text { Buss-Durkee } \\
\text { Hostility-Guilt } \\
\text { Inventory }\end{array}$ & 4.47 & 2.23 & 5.17 & 1.96 \\
\hline Irritability & $\begin{array}{l}\text { Buss-Dirkee } \\
\text { Host ility-Guilt } \\
\text { Inyent ory }\end{array}$ & 5.94 & 2.65 & 6.14 & 2.78 \\
\hline Negativisin & $\begin{array}{l}\text { Buss-Iurleec } \\
\text { Hostility-Guilt } \\
\text { Inventory }\end{array}$ & 2.19 & i. 34 & 2.30 & 1.20 \\
\hline Resentrent & $\begin{array}{l}\text { Luss-burkes } \\
\text { Hostility-Guilt } \\
\text { Invatiory }\end{array}$ & 2.26 & 1.89 & 1.78 & 1.62 \\
\hline Suspleton & $\begin{array}{l}\text { Buss-Durkee } \\
\text { Gustility-Guilt } \\
\text { Inventory }\end{array}$ & 3.33 & $2.0 ?$ & 2.26 & 1.81 \\
\hline Verbal HostIlity & $\begin{array}{l}\text { Buss-Ijurkce } \\
\text { lostility-ciujlt } \\
\text { lnventory }\end{array}$ & 7.61 & 2.74 & 5.82 & 2.59 \\
\hline \multirow[t]{3}{*}{ Guilt } & $\begin{array}{l}\text { Buss-lwrkee } \\
\text { Hostility-Guilt } \\
\text { Invento:y }\end{array}$ & 5.34 & 1.88 & 4.41 & 2.31 \\
\hline & & Wilversity & $\begin{array}{l}\text { Sample } \\
(n=j 68)\end{array}$ & $\begin{array}{l}\text { Juntor } \\
\text { College }\end{array}$ & $\begin{array}{l}\text { Sample } \\
(\mathrm{N}=124)\end{array}$ \\
\hline & & $\bar{x}$ & S.D. & $\bar{x}$ & S.1). \\
\hline Depression & $\operatorname{Jacksora}^{\top}=$ El' & 3.01 & 2.84 & 2.93 & 3.04 \\
\hline Hypochuowitalsts & Jackson's BPI & 4.64 & 3.39 & 4.81 & 3.51 \\
\hline
\end{tabular}




\section{CHAPTER V}

\section{DISCUSSION}

\section{A. Personality Measures Affected by the Concentration Camp Experiance of the Parent}

The results of this study reveal that Children of Survivors differ from Controls on eleven of the twenty personality attributes assessed. The difference was always in the airection anticipated by the investigator. Moreover, the mean scores of both Children of Survivors and Controls fell within the normal range for those measures for which normative data exist.

The findings of this investigation will be discussed in the following manner. First, the results for each of the variables will be interpreted in a methodical fashion. Next, several broader issues which emerged from this study will be comprehensively examined, and the results will be integrated in such a way as to shed light on these issues. Finally, the qualitative data will be discussed and interpreted from the point of view of the cultural and religious identification of survivor progery.

\section{Autonomy and Succorance}

According to the findings, Children of Survivors are more autonomous than Controls, and their Succorance scores are lower. Male Chiidren of Survivors whose parents were Adolescents during WWII had significantly lower scoxes on Succorance then Male Controls whose parents were Adolescents during WTII (see discussion of Children of Adolescent Survivors in 
Section D, below). These results contradict the notion that children of Survivors tend to be cverly dependent, and have so many difficulties asserting their autonomy that their interpersonal adjustment is impeded. (Because of losses that survivor parents sustained, survivor childparent relations are said to have been abnormally dependent and clinging, and that survivor parents discouraged their children from assertion of independence and autonomy.) Two immediate possibilities for these findings come to mind. The first, and most straightforward, is that the survivor parent valued those self-rellant, independent and individualistic traits within himself/herself that helped him/her to survive in the Concentration Camps and encouraged these characteristics in his/her children. The second, more psychodynamically based interpretation, is that the survivor child's relative autonomy may be a defensive reactionformation against unconscious strivings which he/she must not admit to himself/herself. The survivor child may be denying needs to seek cther. peoples' reassurance and advice and be unwilling to admit to feelings of helplessness and dependency.

\section{Innovation}

The results disclose that Children of Survivors are more imnovative and creative than Controls. An explanation for this has its origin in the fact that in order for the survivors to survive and adjust to the Concentration Camps and then to new lives after liberation, they neaded to develop and employ creative solutions to these problems. The parental emphasis on, by now, highly valued imaginative and inventive solutions, probably influenced their children to develop traits associated with imagination and creativity. 
Hostility

The findings reveal that Children of Survivors are significantly more hostile than Controls. It has been said (see Chapter I) that management of rage and aggression has been a tremendous problem for survivors. Outlets were not available for aggressive feelings which accumulated within them during the war. It has been hypothesized that one of the maladaptive ways that survivors dealt with their aggression was to encourage their children to act out the hostile feelings that they denied that existed within themselves. In this way survivor children vicariously gratified their parents' hostile impulses by manifesting aggression in one form or another. The foregoing may serve as an explanatior for the survivor child's greater Hostility (rhan controls). Other explanations were offered in Chapter I (pp. 13, 14), by Danieli, who, while enumerating many resentments harbored by survivor offspring, identified three basic sources of the survivors child's anger; 1) rage towards the Nazis, 2) anger at mankind as a whole, and 3) resentment towards parents for not being better caretakers.

\section{IIypochondriasis}

Children of Survivors, according to the obtained findings, are significantly more hypochondriacal than Controls. This is so for a number of possible reasons. Because of the survivors' experience in the Concentration Camp where their physical needs had been so thoroughly neglected, body preoccupations were subsequently frequent among them.

*

Since the means of five of the seven subhostilities and the mean of Total liostility were significantly larger for Children of Survivors than for Controls, only Total Hostility will be referred to in the discussion of the Hostility variable. 
Further, somatization (the expression of unconscious conflicts via body dysfunction) might be thought of as an unconscious expression of their rage and grief (see discussion of depression), and was, additionally, used as a manipulative device within the family constellation. These attitudes towaris and uses of bodily complaints, preoccupations and malfunctions by the survivors might have easily filtered aown to their children. Somatization and attention to bodily functioning may be one of the survivor children's preferred ways of handing aggression and depression, and achieving domination over others.

\section{Anxisty}

This investigator's findings revealed that while Children of Survivors as a whole were not more anxious than controls, male Children of Survivors were, to a large extent, more anxious than male Controls. Discussion of these results is more fully undertaken in Section $E$, below. It should be kept in mind, however, that in general, survivors were reported to be overly anxious and concerned parents who frequently neglected to provide limits for their children's behavior. In addition, their parenting was said to be inconsistent, varying erratically from overprotective attitudes to neglectful ones, The foregoing parental characteristics and childrearing techniques must have contributed to their sons' relatively high anxiety level.

\section{Trust}

Research results reveal that Children of Survivors are significantly less trusting than Controls, and that male Children of Survivors afe marked1y less trusting than male Controls (see discussion of male.-Sur- 
vivor Children in Section E, below). On the dependent variable of trust, then, both a significant main effect of Camp Experience (Children of Survivors are different from Controls on the dependent variable, trust) as well as a significant Sex $\times$ Camp Experience interaction (male Children of Survivors are different from male Controls on the dependent variable, trust) were present. The large difference between the means of the male Children of Survivors and male Controls accounts for the main effect of Camp Experience. Although female Children of Survivors were not significantly less trusting than female Controls, a comparison of the means showed that the differences between them were in the same direction as for the males.

It was also found that on the subhostility scale, Suspicion, Children of Survivors are significantly more suspicious than Controls. The two findings reinforce one another, and strongly indicate that Children of Survivors, as a group, are wary. of outsiders and Lack confidence in the goodness of people. How can we understand these findings? Firstly, it has been reported that survivor parents taright their children to distrust others and be suspicious of the outside worid. Secondly, it has been noted that the survivor parent was often depressed and withdrawn when the child was an infant. During this period when basic trust is typically established; the parent didn't have the capacity to inspire basic trust in his/her child. This lack of basic trust is manifested in the Adult Survivor Child's relative lack oi faith in others.

\section{Alienation}

The findings of this inguiry revealed that there was an incilnation for Children of Survivors to be more alienated than Controls. According 
to other investigations, the survivors (who already felt isolated and estranged from European society) arrived in this country and felt both Ignored and that U.S. citizens did not take their accounts of their traumatic experiences seriously. An explanation for the Children of Survivors' sense of alienation is that their survivor parents communicated their feelings of isolation and alienation to them.

Anomie

A finding from this present study, in agreement with Sigal et al. (1973), is that Children of Survivors have a stronger tendency than Controls to experience our society as relatively normless. They are more likely to feel that norms of proper conduct are not recognized or subscribed to. Since anomie is one aspect of alienation, this result is consistent with the findings on that variable. The result can be explained by the influence of the survivor parents' attitudes and experiences on their children (that society is chaotic and guided by inconsistent values and principles).

Sex-Specific and Male-Valued Items (M/F Scale)

The research revealed that Children of Survivors as an entire group were not different from Controls on sex-specific and male-valued items. Sex-specific items assess. how stereotypically masculine or feminine the ideal male or female is conceived of as being. Male-valued items assess the degree of identification with stereotypically male traits. However, Children of: Survivors whose Parents were Adults during wi II had significantly lower sex-specific scores than their corresponding Controls, 1.e., Male children of Adult Survivors perceive the ideal male as heing 
more stereotypically feminine than corresponding Controls, and Female children of Adult Survivors conceive of the ideal female as being more stareotypically feminine than their corresponding Controls. Similarly, Children of Survivors whose Parents were Adults during WW II had significantly lower scores on male-valued items than their corresponding Controls, i.e., Children of Survivors whose Parents were Adults during Tw. II have not identified with behaviors and traits that are regarded as stereotypicaily masculine to the degree that their corresponing Controls have. On the other hand, Children of Survivors whose Parents were Adolescents during IWW II had significantly higher scores on malevalued items than their corresponding Controls. These findings will be discussed in detail in Sections $D$ and $E$, below, which deal with the differences between Children of Survivors whose Parents were Adolescents in the Concentration Camps and Children of Survivors whose Parents were Adults in the Concentration Camps, and the issue of the vulnerability of the Concentration Camp Survivor Father, respectiveiy. 


\section{Fersonality Measures Wot Affected by the Concentration Carip Experience of the Parent}

There was no difference between Children of Survivors and Controis on nine of the personality characteristics assessed. While it is difficult to find justifications for some of these findings, others may be somewhat more comprehensible.

\section{Interpersonal Affect}

There was no significant different between the Children of Survivors and Controls on this variable which assesses empathy, sympathy and compassion for others. The Children of Survivors might have scored higher on interpersonal affect than Controls, since they were aware of their parents' suffering and were said to be determined to protect them Irom further paj. Their characteristic concern for their parents might have generalized to all individuals but there is no evidence for this Erom the data.

Female-Valued Items (M/F Scale)

Chilàren of Survivors and Controls show no difference in sccres on female-valued items, which assess the extent to which individuals heve incorporated, as part of their identity, behaviors and traits that are regarded as stereotypically female. Since these traits represent identification with feminine characteristics as exhibited by the mother, this finding implies that survivor mothers were as available for sexidentification as mothers of controls.

\section{Fear}

There is no difference between Chiidren of Survivors and Controis 
In the scores on this variable. Total Fear reflects, according to

McReynolds (1968) who described the FSS-II, overall anxiety. (There

is a difference in scores on this variable tetween Children of Survivors whose Parents were Adults during WW II and Children of Survivors whose Parents were Adolescents during WW II, but this is discussed in Section D). Fear and Anxiety (see the foregoing discussion of Anxiety) both seem to assess similar personality dimensions. The Anxiety variable looks at the "consistent level of anxiety as it has developed over the course of an individual's 1ifetime" (Jackson, 1976). There is a difference on Anxiety between the Children of Survivors and Controls (male Children of Survivors are more anxious than male Controls), while there is no difference between the two groups on Fear. A possible explenation For this disparity is that Fear, as measured by Geer, "refers to specific responses to specific stimuii" (Geer, 1965). Anxiety, as conceived of by Jackson, and Fear, as understood by Geer, may be scmewhat different cuncepts, and it is this disparity that may be accounting for the lack of difference between the experimental subjects and controls on Fear, and the difference between the two groups on Anxiety.

\section{Abasement}

There was no difference between the Cnildren of Survivors and Controls on this variable, wich assesses guilt in an indirect manner by examining self-blaming and self-critical attitudes. There was also no difference between the experimental and controj groups on the variable Guilt (part of the Buss-Durkee scale). The Guilt scale looks at feelings of being bad, having done wrong, and sisfering pangs of conscience. These findings are most surprising (even though they agree with Rustin, 
1971) since the survivor parents' Survivor Guilt ("Why did I Iive while others died?") pervaded every aspect of the survivor childs" family life. How could this atmosphere not have facilitated the experience of intense guilt feelings on the part of Survivor Children?

\section{Depression}

The findings revealed no difference between the Children of Survivors and Controls on Depression. These results, like the guilt findings, are unexpected. According to prior research, an atmosphere of depression permeated most survivor homes. Survivors were unable to mourn in the Concentration Camps, and the result of this failure to mourn was a continuing depression. In order to relieve thei= parents' depression, Children of Survivors are said to have attempted to do their parents' mourning for ther (in addicion to their ow: mourning for lost relatives). The foregoing would surely have contributed to the survivor child's depression. In addition, it has been suggested that the survivor parents' prenccupation with the past resulted in their inability to be enotionaily available to their children (Sigal, 1971). The child of survivors is assumed to have reacted to this emotional neglect by becoining depressed. Also, as part of the natural identification process, it has been proposed that the survivor child identified with (a) depressed parent(s) (Sigal, 1971). This wolld likely have contributed to the survivor child's depression, as would nis/her turning of his/her aggression inward (Nenman, 1979) and his/her continued exposure to Holocaust stories (Trossman, 1968 ). The obtained resuits on Depression challenge ane of the most strongly held notions concerning the character of Children of Survivors. 
How can we understand the findings we have obtained on Guilt and Depression?. There are three possible explanacions, two of which are intertwined.

For the moment, let us make the assumption that the survivor child (although unconsciously guilty and depressed), has both consciously and unconsciously decided to deny Hitler a posthunous victory. At no cost must the Nazis (or the world) be allowed to witness more than they already have, the horrific effects of the Concentration Camps and of Nazi extermination policies on the Jews. This theme of indomitability is emphasized in post-Holocaust literature, and in songs written by Jews for Jews during and after World War II. Let us further assume that Children of Holocaust Survivors have by now been so sensitized to their own "issues" that they are aware that guilt and depression are the hallmarks of the survivor child, and either mark him/her as "psychopathological" or otherwise demean him/her. By revealing his/her depression and guilt he/she will acknowledge that Hitler has won; that the Nazis have maimed the Jews in general, and himself/herself in particular. By his/her displaying guilt and depression the survivor child might also be labeling bis/her parents as depressed and guilty themselves (he/she might be simply identifying with a depressed parent), or indirectly be accusing them of being poor parents (by raising a depressed and guilty child). Both of these actions would mark the survivors themselves as being further crippled by Hitler. Furthermore, the Children of Survivors may be wary of admitting to depression and guilt, fearful of hurting their parents who have already suffered so much. In adoition, were the parents to experlence pain at their child's unhappiness, the Child of Survivors would feel even more guilty. 
As a consequence of his reluctance to manifest guilt or depression, the surrivor child may be quick to identify items in these two areas, and 'fix' them to show little or no depression or guilt. The recognition of the intent of the question and the motivation behind the response would likely be subconscious. On the other hand, it could legitinately be argued that test construction was such as to suppress the desirability component of each iten. 'Fixing' responses to achieve a particular socialiy desirable outcome is difficult. It should be noted, however, that the items assessing Depression, Guilt and Abasement are somewhat obvious in their intent.

Because guilt and depression are Holocaust stigmata, and because the experience of these affects is painful, it may be that the survivor child deals with them in yet another way. He/she might unconsciously alter his/her feelings of gujlt and depression so that they emerge as hostility (hostility, guilt and cepression are all psychodynamically closely related). In this connection, note the Child of Survivors relativeiy ligh mean score on Hostility. In addition, much of the depression might be expressed somatically note the high Hypochondriasis score for Survivor Children).

\section{Social Activism}

This study revealed that Children of Survivors and Controls did not obtain significantly different scores on Social Activism. It was thought that because survivors bore the brunt of social injustice in the Concentration Camps and communicated their sliffering in this area to their children, that Children of Survivors would have a deeper sense of social responsibility and nore of an orientation towards helping 
others than Controls. It may be that Children of Survivors are less socially responsible than expected. The fact that both the experimental and control groups achieved relatively sinilar scores on Social Activism may be due to $10 w$ or mid-range scores on the part of both groups. Or, it may be that the Controls' score was higher than expected, and that both groups were relatively high scorers. Since norms weren't established for this Structured Interview variable, it is impossible to say which is the case. If the Controls scored higher on this variable than anticipated, it may be that as former residents of Nazi-occupied countries, their parents also experienced the humiliation associated with social injustice. These refugee parents may have imbued their children with strong feelings of social responsibility which might be as intense as the Survivor Childrens'.

\section{Powerlessness, Meaninglessness of Iife and Isolation}

The findings showed that Children of Survivors and Contrals did not obtain significantly different scores on any of these three Structured Interview variables (Alienation sub-variables). The mean scores for the Survivors' Children on each of these three variables were higher thar the Control's, and assures us that they contributed positively toward the main effect trend of Camp Experience for Alienation (Children of Survivors are somerhat more alienated than Controls) noted above. 


\section{Personality Measures Af Pected by Sex dnd Developmental Level, but not Concentration Camp Experience}

Results were obtained in the study that have no direct relation to the Concentration Camp Experience, but are worthwhile mentioning for their heuristic value.

\section{Interpersonal Affect}

On this scale, which assesses empathy and compassion for others, the Fenales scored significantly higher than the Males. The relation of female scores to male scores was the same as for the population used to establish the instrument's norms (JPI).

\section{Succorance}

The Females scored significantly higher on this scale, which appraises heiplessness and dependency, than the Males. The relation of female scores to male scores was the sane as for the population used to establish the irstrunient's norms (PRF, Form AA). In addition, a significant Second-Order interaction was obtained on Succorance (Sex $\times$ Developmental Level $\times$ Camp Experience). The analysis of this interaction revealed that the nain effect of Sex can be traced to the fact that Female Controls whose parents were Aduits during WW II had higher Succorance scores than the corresponding Male Controls (this was discussed in detail in the Results Section). The analysis also showed that Male Controls whose parents were Adolescents during WW II scored higher on Succorance than Male Controls whose parents were Adults during, iW II. 


\section{Autonomy}

On Autonomy, the Males scored significantly higher than the Females. The relation of the male scores to the female scores in this study was the same as for the population used to establish the instrument's rorms (PRF, Forn AA). In addition, the Children of Parents who were Adults during WW iI had significantly h'gher means on this scale, which assesses self-reliance and independence, than the Children of Parents who were Adolescents during WN II.

\section{Sex-Specific (M/E Scale)}

Males scored significantly higher than Females on the sex-specific items which appraise how stereotypically masculine or feminine the ideal male or famale is conceived of as being. The relation of the male scores to the Iemale scores vas the same as for the population used to establish the instrument's reliabilities and validities (PAQ).

The origin of the main effect trend of Developmental Level (i.e., that the Children of Parents who were Adolescents diring WW II, in this study, had significantly different sex-specific scores than the Children of Parents who were Adults during W II), lies in the fact that Children of Survivors whose Parents were Adults during WW II, had significantly lower sex-specific scores (this was discussed in detail in the Results section).

Female-Valucd (M/F Scale)

Females scored significantly lower than Nales on the female-valued itens which evaluate the degree of fientification with stereotypically 
female traits. The relation of the female scores to the male scores

was the same as for the popilation used to establish the Instrument's reliabilities and validities (PAO).

Male-Valued (M/F Scale)

The absence of an expected main Sex effect on this variable (which assesses the extent of identification with sterectypically male traits), i.e., that Male subjects did not score significantly higher than Female subjects, can be traced to the fact that Female Children of individuals who were Adolescents during WW II attained scores that were somewhat higher than Male Children of individuals who were Adolescents during m II. (There was a significant Male-Female difference in Male-valued scores for the Children of individuals who were Adults during WII. Males scored higher than Females.) (See discussion in Results section.)

\section{Eypochondriasis}

The Children of Parents who were Alults during Horld Tiar II had significartly higher mean scores on this scale, which assesses bodily concern, and preoccupation with physical complaints, than Children of Parents who were Adolescents during World Tar II.

\section{Innovation}

The Children of Parents who were Adolescents during WU II are significantly more innovative and imaginative, according to the findings of this study, than Children of Parents who were Adults during WW II. 


\section{Alienation and Fowerlessness}

The Children of Parents who were Adults during WW II were found to feel significantiy more poweriess than the Children of Parents who were Adolescents during WW II.

A significant Sex $\times$ Develcpmental Level interaction was obtained for Powerlessness and a marginal Sex $\times$ Developmental Level interaction was obtained for Alienation. These interactions were not analyzed because they were not directly relevant to this study (levels of Camp Experience were not involved). 


\section{Children of Adolescent Survivors vs. Children of Adult Survivors}

This study revealed no indication that Children of Survivors who were Adolescents in the Concentration Camps were more affected by their parents' Concentration Camp experience and cope less effectively than Children of Survivors who were Adults in the Concentration Camps. In fact, if there is any indication of a difference between the two groups, it would have to be that the Children of Survivors who were Adults in the Concentration Camps were more affected by their parents' trauma.

On the majority of the dependent variables assessed, no difference between Children of Survivors whose parents were Adults in the Concentration Camps and Children of Survivors whose parents were Adolescents in the Concentration Camps were noted. Only three interaction (Camp Experience $\times$ Developmental Leve1) effects on the three variables: Fear, MaleValued behaviors and Sex-Specific behaviors were obtained that could shed light on the differences between these two groups. On the dependent variable, Fear, Children of Survivors whose parents were Adults in the Concentration Camps were somewhat more fearful than Children of Survivors whose parents were Adolescents in the Concentration Camps. The Children of Survivors whose parents were Adults in the Concentration Camps appear to cope less well with specific stimuli that elicit fear.

Children of Survivors whose parents were Adults in the Concentration Camps had lower mean scores on the variable Male-Valued (M/F scale) than Children of Survivors whose parents were Adolescents in the Concentration Camps (shortened, for convenience, to Children of Adolescent Survivors). This may mean that Children of Survivors whose parents were Adults in the Concentration Camps (shortened, for convenience, to Children of Adult Survivors) have not incorporated, as part of their identity, behaviors 
and tralts that are regarded as stereocypically male to the degree that Children of Adolescent Survivors have. These behaviors and traits have to do with methods of coping with the external enviroment, competence, and accomplishing things. These results may indicate a tendency on the part of Children of Adult Survivors to possess somewhat less adaptive mechanisms for coping with the external environment.

Finally, the two groups differed on the Sex-Specific (M/F scale) variable. Children of Adult Survivors had lower scores on these items than Children of Adolescent Survivors. This indicates that Male Chilcren of Adult Survivors perceive the ideal male as being distinctly more stereotypically feminine than Male Children of Adolescent Survivors, and that Fenale Children of Adult Survivors conceive of the ideal female as being more stereotypically feminine than Female Ctildren of Adolescent Survivors. It appears that Male Children of Adult Survivors may, in some measure, be uncertain of thejr male identities (see the discussion below), while Ferale Children of Adult Survivors approach the stereotyped view of femininity a bit too closely. These conceptions of their sexual identities on the part of Male and Female Children of Adult Survivors (particularly the Males) could conceivably cause some adjustment difficulties in our society.

When looking at the differences between Children of Survivors and Controls on the male-valued items, orie's attention is drawn to the fast that the mean for Children of Adolescent Survivors is higher than the mean for their corresponding Controls, while the mean for Children of Adult Survivors is lower than the nean for their corresponding Controls. From this perspective as well, then, there is support for the notion that Children of Adolescent Survivors have more than adequate means of 
coping with the external world.

Upon examination of the differences between Children of Survivors and Controls on the sex-specific items, one becomes aware that Children of Adult Survivors had significantly lower sex-specific scores than their corresponding Controls. This finding, in conjunction with the earlier result that Children of Adult Survivors have lower mean scores on sex-specific items than Children of Adolescent Survivors, is further evidence that male and female Children of Adult Survivors have ideals for males and females that don't conform to society's ideals for the two sexes.

The second-order interaction (Camp Experience $\times$ Sex $\times$ Developmental Level) obtained for Succorance, revealed that Male Children of Adolescent Survivors had significantly lower scores on this dependent variable than their corresponding Controls. The main effect of Camp Experience for Succorance is in fact determined by the difference in mean scores between these two groups. The Male Children of Adolescent Survivors are relatively independent, show less need of sympathy and support, and.seek less reassurance frora others. This is further evidence for the contention that Children of Adolescent Survivors were not necessarily affected in an adverse manner by their parent's Concentration Camp experience. Certainly the Maie Children of, Adolescent Survivors appear to be a relatively.confident, secure, and self-sufficient group. By contrast, there was no significant difference between mean Succorance scores achieved by Male Children of Adult Survivors and their corresponding Controls.

What is the explanation for the fact that Children of Adolescent Survivors were not as negatively affected by their parents' camp experlences as was hypothesized, and that, conversely, Children of Adult Sur- 
vivors may have been influenced more?. Why were the survivor parents' effects on their children different from expectations?

The explanation may lie in the fact that adolescents are more resilLent than has been supposed -- more adaptive even than adults -- to trauma. Adolescents may be less vulnerable to temporally bounded trauma (as exemplified by the Concentration Camp) than adults. Or, we may find the explanation in the fact that adults generally experienced a greater degree of loss than adolescents did (not only did adult survivors lose parents and siblings, but they also lost spouses and children). It is possible to explicate the findings by asserting that while the adolescent was more vulnerable to trauma (than the adults), nis/her vulnerability was balanced and even superceded by the adults' enormous losses. Finally, we might understand the finding; by supposing that there may, in fact, have been a more destructive effect of the Concentration Camps on the adolescent, but that in the process of the transmission of the effects of trauma from one generation to the next, this effect was attenuated. The stronger effect of the experience of the Concentration Camps (as opposed to no camp), was visible, but the more subtle effects -- the differences between different groups of survivors -- were not. 


\section{E. Vulnerabilizy of Male Surrivors: Male Identity}

There are four variables: Trust, Anxiety, Male-Valued behaviors and Sex-Specific behaviors which proved to be especially sensitive to the influence of the Concentration Camp Survivor Father. As the clinical literature has indicated, the male who experienced the trauma of the Concentration Camp was more profoundly affected than the female. His traumatization expressed itself in an exacerbation of symptoms associated with the Survivor Syndrome, and in an exaggeration of personality characteristics generated by the Concentration Camp experience. In attempting to cope with psychic remnants of the Concentration Camp experience, the father emotionally and physically withdrew from his family by throwing himself into his work. Even when he was physically present, he maintained his emotional distance from his family.

As has already been mentioned, Children of Concentration Camp Survivors are less trusting than Controls. Closer examination of the data revealed that male Children of Survivors were markedly less trusting than male Controls, while female Children of Survivors and Controls exhibited approximately the same amount of trust in people. To explain this result in the light of the foregoing discussion, we might hypothesize that the Survivor Father was noticeably distrustful. The male child of this parent would likely identify with his suspicious father. The male Child of Survivors' low trust in people may have an additional source. We have already discussed the general low level of trust in the survivor home. This wary attitude towards others becomes more pronounced with males. They may be, for the most part, required to involve thenselves in dealings with a sometimes threatening. and hostile business world (67\% of the males in this study are businessman or lawyers) which strains their 
limited reserves of trust. Females, on the other hand, may more frequently either assume a protected domestic role, or be employed in the service sector $(25 \%$ of the females in this study are housewives, $21 \%$ are businesswomen or lawyers, and $31 \%$ provide services).

The results of this study disclosed that male Children of Survivors were considerably more anxious than male Controls, while female Children of Survivors and Controls were anxious to the same degree. With regard to the role of the survivor father already alluded to, we might conjecture that the survivor father was very anxious. The son of this father would be inclined to identify with his fearful parent. An additional origin of anxiety in the male Child of Concentration Camp survivors may lie in the survivor parents' overly high expectations for their children. Survivor parents likely have especially high hopes (professional and academic) for their sons.

The issue of male identity for the survivor children, and the inEluence of the survivor child's father are effectively probed by two $M / F$ scale variables: Male-Valued behaviors and Sex-Specific behaviors. Both rale and female Children of Adult Survivors had low means on male-valued items. Since these items assess the degree of identification with stereotypically male traits, the implication is that these two groups possess relatively fewer male characteristics, and perhaps cope less actively with the external environment. This phenomenon also appears to be related to the relative emotional distance of the Adult Survivor father. Again, the children (both inaie and female) of this survivor parent had only an emotionally distant father figure with whom to Identify.

It must be noted, however, that the low means on male-valued items 
were obtained for the Children of Adult Survivors only, and not for Adolescent Survivors (or the Controls whose parents were Adults during WW II). This would indicate that males who were adults in the Concentration Camps were more deepiy aifected by the experience than maies who were adolescents in the Concentration Camps. The reasons for adult vulnerability to trauma were mentioned above. This vulnerability on the part of Adult Survivors appears to be greater for males. On the sexspecific items, as on the male-valued items, both male and female Children of Adult Survivors achieved lower means than male and female Children of Adolescent Survivors, and male and female children of Coritrols whose parents were Adults during WW IJ.

As noted earlier, these results imply that both male and female Children of Adult Survivors -- but particularly males -- have atypical pexceptions of the ideal nember of their respective sexes. Male Children of Adult Survivors conceive of the ideal male as embodying many more Eeminine characteristics than the males in either of the aforesaid groups. This finding suggests that the male Children of Adult Survivors may have more androgynous sexual identities. The cause of this phenomenon may be traced to the emotionally uninvolved and physically unavailable father who was an Adult in the Concentration Camps.

As with male-valued items, only the Children of Adult Survivors were different from the other groups. Again, the implication is that Adult Male Survivors were nore negatively influenced by the Concentration Camp experience. 


\section{F. Normality of Cinildren of Survivors}

One of the most important results of this Investigation was the discovery that despite measurable differences between Children of Survivors and Controls, the mean scores obtained by both groups on all the dependent variables (but one*) were within the normal range. The normal range is here defined as the mean score obtained on the standardization sample of normal subjects \pm 1 S.D. (see Tabie 36 ). This is of parti.cular relevance to the Children of Survivors, who have until now been mainly thought of as a "psychcpathological group." The fact that Children of Survivors obtained normal mean scores is strong evidence for their normality.

This finding, that Children of Survivors are within the normal range (at least on the variables examined), contradicts almost all the previous research (except Rustin, 1971; Leon, Butcher, et al., 1981; and 21otogorski, 1983), which had emphasized the psychepathology of the survivor child. The prevalent view, that the survivor child was indelibly stamped as emotionally deviant originated primarily from two sources: 1) Case studies conducted by psychoanalysts (whose orientation is towards psychopathology) emphasized the psychic dysfunction of the children of survivor patients, and 2) Most of the previous empirical research had been conducted on clinical samples (and generalized to the entire population

The mean Fear scores obtained by a11 the subjects in this sample were greater than the mean scores for inales and females obtained by Geer (FSS-II). The difference excecied one S.D. for the females and two S.D.'s for the rales. The means and S.D.'S for the FSS-II are based on a sample of $16 I$ male and 109 female subjects. On the well-standarized Jackson scale (IPI), which assesses the consistent level of anxiety as it has developed over the course of a person's lifetime, all the subjects scared in the normal range. The FSS-II scores also reflect overall anxiety, yet all subjects scored above and outside the normal range. While it is not vithin the scope of this study to explore this discrepancy, in this connection it should be pointed out that the JPI was standardized on a sample of 2,000 males and 2,000 females. 
of survivor children). The earlier work stands in marked contrast to the present study which was conductec on a carefully drawil sample of "normal" Children of Survivors and Centrols, and is conspicuously free of sample bias.

From this perspective, then, is it useíl to talk about a "SurvivorChild's Syndrome," since the assessment of those personality characteristics which might be influenced by the parents' camp experience shows them not to be different from that of normal individuals? This investigator believes in the utility of the idea of a "Survivor-Child's complex" (Kestenberg, 1982). This concept acknowledges the impact of the survivor parent on his/her child, but visualizes this impact as producing a constellation of uutstanding personality attributes, within the normal range, that is urique to children of survivors.

The tacit assumption underlying this study and previous investigations, has been that personality characteristics caused by the trauma of the Holocaust are transmitted from one generation to the next. How then is it possible to explain the "normality" of the survivors' children given this supposition? More specifically, why do the personality characteristics associated with the survivors' pathological response to the Holocaust appear in their children in an attenuated and "normal" form?

The difference between parents and children with regard to Holocaustrelated characteristics might be due to the fact that the parents' Concentration Camp trauma was experienced in a relatively acute time-1imited manner, while the child's experience of his/her parents' questionable child-rearing techniques was more in the form of a chronic "cumulative trauma" (as described by Grubrich-Simitis on p. 36). 'The parents' trauma 
resulted in the severe symptoms termed the Survivor Syndrome, but the survivor childrens' trauma resulted in a significantly attenuated form of the Survivor Syndrome; already referred to as the "Survivor Child's complex."

Another plausible explanation for the results obtained for the survivor children is the hypothesis that the survivors themselves were affected, but not in so profound a way as has been supposed. The majority of the investigations carried out on the survivors weregared to the determination and exploration of psychopathology. Most studies were done on survivors who had filed restitution claims with the German government, and were undertaken by psychoanalysts whose orientation was, almost by definition, toward psychopathology. Is it possible that these studies exaggerated the survivor's maladaptive characteristics? If this is so, then the survivors would have transmitted a much milder form of the syndrome to their offspring. This would also account for the differences between Children of Survivors and Controls on the forementioned constellation of personality traits. The normality of this constellation is also comprehensibie in the iight of this hypothesis. 


\section{G. Heterogeneity of Survivors and of Childien of Survivors as Accounted for in the Research Design}

A lingering question in the Holocaust literature has been whether studies on the effects of the Concentration Camp on survivors and their children are worth undertaking, since both groups, survivors and survivors' children, are so hetarogeneous. How can we, some researchers argue, look for a common effect of the Concentration Camp on survivors' children in the light of the facts that: 1) The individuals (survivors) who entered the Concentration Camps were so varied (in terms of personality, cultural background, etc.); 2) The camp experiences themselves were so diverse (ages during incarceration differed, intensity of type of stress varied, the length of rime spent in the camps was not the same, types of losses varied, etc.); 3) The post-Camp experiences of the survivors were so different? How is it possibie, they question, that the experience of the Concentration Camp ultimately had a uniform effect on all Children of Survivors when not only were the survivors' pre-Camp, Camp and post-Camp experiences unigue, but their reactions to their experiences -- the ways that they dealt with the Concentration Camp trauma -were unique as wel1? Finally, these researchers query, how, considering the forementioned, can the child-rearing techniques of the Holocaust survivor parents resemble each cther enough, and how can other family variables (numerical size of family, order of birth, sex of parent who was a survivor) be sufficiently similar to reveal the traumatic effect of the Concentration Camp on the parents as the cause of a conmon effect on the children? Isn't it so, these doubters might say, that the questionable "effect" of the Concentration Camp on the Survivor Children is a fluctuating interaction of all the possible factors mentioned above with 
the experience of the Concentration Camps? And if this is so, then a uniform effect on the child of survivors of kis/her parent's Concentration Camp experience cannot exist.

What these skeptics fail to recognize is the overwhelming impact of the Concentration Camp experience and its profound traumatic and stressful effect. - an effect that transcends the influences or combinations of influences of all the above factors on the survivor and his child. What they are also insufficiently-aware of is that the Concentration Camp experience is the only experience that all the Concentration Camp survivors and their children (in an indirect manner) share.

This brings us to a discussion of the present study. This investigator was fully cognizant of the primary impact of the trauma of the Concentration Camp on both the survivor and his/her child, and accounted for the abundant factors mentioned above by randomizing the subjects on these factors. According to Kerlinger (1973) "... randomization is the cnly method of controlling all possible extraneous variables." (We can consider all the factors mentioned in the above argument as extraneous variables.) "... control of the extraneous variance by randomization is a powerful method of control." In other words, by controlling the extraneous variables, we are assuring ourselves that the effect we have obtained is due to the experimental condition and not to confounding, uncontrolled independent variables.

After the study was completed, inspection of the data revealed the possibility that certain extraneous variables might be "confounding" the study, i.e.,having an effect on the outcone of the study. The variables that appeared to be possible confounds for all the subjects were: their level of education, Income, birth-order, their parents' country of origin, 
their relative amount of freedon during childhood and whether they were allowed to be on their own, the ability of parent and child to confide in one another, their familiarity with the Holocaust literature, their parents' physical health, whether they had experience in psychotherapy, and the state of their emotional well-heing. Possible confounding variables for the Children of Survivors were: presence or absence of a D.P. Camp in the survivor parents' post-Concentration Camp experiences, and whether one or both parents were Concentration Camp survivors. Regression analyses of the data revealed no significant effect for these factors -- these extraneous "independent" variables did not influence the dependent variables in this study.

A word must be said here concerning those researchers who emphasize the heterogeneity aspect of the survivor and children of survivor groups. These investigators Eeel, particularly for psychotherapy purposes, that these affected individuals have been frequently treated witiout enough regard for their individuality. Furman (1973) steaks for this group of investigators by stating, "Any tharaputic work must put aside stereotyping of the survivor and his children," and "I stress the reed to study individual cases intensively, avoiding tempting generalizations in order to understand ... the children of survivors." 


\section{H. Discussion of Qualitative Data}

Both logic and previous research (Porter, 1981; Kuperstein, 1981; Heiler, 1982; Krel., 1979) aid in the prediction of various attitudes and behaviors of children of survivors with regard to issues of Jewish cultural and zeligious identification. It is reasonable to expect that children of Holocaust survivors would be so affected by their parents' direct and indirect accourts of their traumatic experiences that they would express in both thought and deed the resolve that the Jewish people would never be destroyed. This need to prevent extinction of the Jewish people might be expressed by children of survivors in various ways: 1) in an interest in Israel and the need to preserve it for the continued survival of the Jews; 2) in agitating for freedom from persecution for the Soviat Union's Jewish population; 3) in being Jewish activists, organizing and involving themselves in Jewish communal groups (religious, political, Holocaust-related), editing Jewish magazines, etc. The comitment to Judaism might also reveal itself in strong responses to anti-semitisn, great interest in Jewish-related issues, religious lifestyles and strong feelings of jewish identity (pride, uniqueness and the sense of heing a link in the chain of a long history and culture).

A gualitative examination of the data discloses some interesting findinge. Not oniy would it have been axpected that children of Holocaust survivors would manifest the feel.ings and behaviors cited above, but that they would exhibit them to a greater degtee than children of non-survivors. This expectation was not consistently borne out in the present study. 


\section{RELIGIOUS TRAINIING}

It might have been considered likely that Holocaust survivors' children would have had more religious training than the controls, considering their parents' history and experiences. A question was inserted Into the Life History Questionnaire to investigate this issue. While the experimental groups had more Orthodox training than the control groups, the percentages of both groups (experimentals and controls) who had had religious training of sone kind were about the same (59\% for the experimental groups, $62 \%$ for the control groups).

\section{FEELINGS ABOUT JEWISHNESS}

The Life History Questionnaire query "Describe the Eeelings your Jewishness engenders in you" brought forth some telling responses. Of the controls, approxinately $78 \%$ had positive thoughts about Judaism, $3 \%$ negative thoughts and $19 \%$ mixed or neutral ones. In the experimental groups, about $84 \%$ had positive feelings, $0 \%$ negative feelings and $9 \%$ neutral or mixed ( $7 \%$ did not respond). Although the experimental and control subjects both had basically positive feelings about their identity, children of survivors generally seemed to be more passionate in their expression. Nearly $41 \%$ of the children of survivors expressed very strong, deeply felt emotions regarding their Jewish identity, while $30 \%$ of the controls revealed these intense sentiments.

The positive thoughts that Jewishness produces in subjects include: 1) Fride in being Jewish. One experimental subject responded "A deep sense of pride and obligation -- warnth and joy for the traditions of the religion and sometimes even comfort for the guidance of Judaic Law." 
2) Jewishness being a strong source of personal identity. "Sonetimes I feel I exist just to be Jewish," saic another subject. 3) The separateness and distinction of being Jewish. "A sense of being different, proud ... special," added a control subject. 4) The notion of being tied to a significant history and tradition. "A sense of pride-meaningful continuity with the past and meaniugful direction for the future," mentioned an adult experimental subject. 5) Jewishness bound up with feelings of conmitment. Said one survivor's child, "I am deeply comnitted to Judaism." For children of Holocaust survivors, Judaism often has a special, positive meaning. One adolescent chiid of a survivor poignantly stated: "It is my touchstone. It is jound up with being a second-generation survivor. Together they form my heritage, and it is the heritage I want to pass on to my daughter." Positive sentiments about Jewishness often include the desire to transmit the Jewish legacy to one's children. "... I am very proud of ny heritase and hope to instill my feeings in my children," emphasizes a control subject. The passing on of the Jewish heritage is seen as accomplished by formaI education in the Jewish tradition. "I keep a very traditional horne," says an adult survivor's child, "and send my daughter to a Jewish day school."

Some subjects' statements conceruing Jewish identity suggested the fragility of the future for Jews. "I have ... a worrisome attituda about what will eventually happen to the Jewish people," stated an adult control. Other statements conveyed a lack of trust of the gentile world. One subject confided: "There is a certain sense of defensiveness associated with feeling like a part of a people that has a history of being discrininated against." While another said: "I'm somewhat 
paranoid about anti-semitism and less comfortable in an atmosphere that is predominantly gentile."

Only about $16 \%$ of the controls (two Orthodox, two Reformed, one Conservative) view thenselves as Jews in the religious sense, and $13 \%$ feel that allegiance to Israel is an important part of their Jewishness. $84 \%$ see themselves as Jewish in the traditional, cultural conception of the term. They recognize the importance of the Jewish heritage and prize the ethics and values of Judaism. A control subject stated: "My Jewishness has always been a fundamental and strong force in my life. Not so much the religion itself, but the heritage and belief in Jews." They feel comfort in being with and having a tie to other Jews, and in having religio-ciltural roots. Arother control subject reported: "I try to live by Jewish values. But I always feel a lot of pride in being a jew. I an also conscious of our history and tradition, and try to use today, our lessons of the past. I an very comfortable with Jewish beliefs and customs."

Almost $44 \%$ of the children of survivors (trelve Orthodox, two Conservative) regard themselves as Jews in the religious as well as in the traditional, cultural sense. $6 \%$ claim that the most important aspect of their definitjon as Jew is their Zionism.

$6 \%$ of the controls intermarried, whereas there was no intermarriage among the experimental subjects.

\section{INVOLVEMENT IN JEWISH COMMUNIIYY AFFAIRS}

Responses to the Structured Interview Question: "Feople have different ideas and experiences of just how they fit into the affairs of the conmunity. Would you say that you contribute to community decisions 
or that you are not part of the community at a11, or perhaps, somewhere between these two poles?" were scrutinizad for the extent of the subjects' ingolvement in Jewish commuity afiairs. . It was conjectured that responses to this query wolld heip gauge the degree of cuitural and religious identification.

The percentage of controls and the percentage of the experimental group subjects who were not involved in the jewish community was the same: approximately 56\%. The percentage of the experimental subjects fully involved in the Jewish community was close to $41 \%$, and the percentage of the experinental subjects somewhat involved was about $3 \%$. Approximately $34 \%$ of controls were deeply involvel in the Iewish community and about $9 \%$ were somewhat involved. The percentages of the controls and the experimental groups at all involved in Jewish comminity affairs is remarkably similar.

The control's jewish communty work included fundraijing, involvement in synogegues, Zionist organjuations, and political groups. In adition to those community functions already mentioned, experimental subjects took part in Holocaust survivors' and survivors' chilcran groups, Jewish school teaching, Soviet Jewry lobbying and contributing to Jevish communal publications.

COMMTTMENT TO JEWISH CALSES AND ISSUES

Responses to the questions assessing Social Activism in the Structured Interview were informal1y examined for Jewish-ralated content. More specifica11y, how different or similax were the experimental anci control subjects in their conmitumt to jewish causes and issues? The degree of their sense of obligation to thirgs Jewish word suggest the 
strength of their Jewish identity.

The percentage of the experimental subjects that mentioned significant comitment to Jewish issues and causes in their responses was around 56\%. Titie percentage of experimental subjects that suggested but a 1ittle commitment to Jewish activities was around $16 \%$. Only approximately $23 \%$ of the experimental subjects mentioned no involvement in Jewish causes. Approximately $28 \%$ of controls cited a significant involvement in Jewish causes and activities and about $9 \%$ stated a $\underline{\text { little }}$ commitment to Jewish causes. A whopping $63 \%$ of the controls specified no engagement in Jewish causes and issues.

The issues and activities which the control group subjects indicated comnitment to included Russian Jewry, Israel, Jews in foreign lands (anti-semitic activities), matters of social injustice and discrimination as they relate to Jews, Jewish political groups, Jewish (wumen's) organizations, Jewish ₹eminism, Jewish comnunity service, and "general Jewish issues." The experimental subjects cited all the areas of Jewish interest mentioned by the controls, and in addition, stressed involvenent in educational and conscicusness-raising activities connected with the Holocaust, and active participation in Holocaust organizations.

CONCLUSIONS AND EXPLANATIONS

The data provided here indicate that on most of the informal measures of Jewish religious and cultural identification, there is Iittle or no difference between the experimental and control subjects. It was expected that children of survivors would have stronger Jewish identifications than controls. There are two possible explanations for 
this phenomenon. Firstly, the parents of control subjects are themselves, in a sense, survivors. They too were victims of Nazi persecution and suffered geographic displacement and many losses [of some relatives (but not nearly to the extent of Concentration Camp survivors), homeland, culture, etc.]. It is likely that these immigrant parents (parents of control group subjects) were, like survivors of Concentration Camps, aware of their vulnerability as Jews, and communicated this feeling of vulnerability to their children. This influenced the controls to contribute their efforts to the cultural preservation of the Jews. In addition, a large percentage of the controls' parents are or were members of a well-known Reformed synogogue in New York City. By virtue of their involvement in the synogogue, we might hypothesize that the controls" parents themselves were more deeply committed to Judaism, say, than a group of refugees from Germany who had not been at tached to a synogogue. It is highly possible, then, that the parents of the controls inculsated Jewish values and the need for Jewish survival into their children.

Although sirnilar positive feelings about their Jewishness were expressed by members of the experimental and control groups, the children of survivors expressed themselves in a more intense and forceful way. The strong emotionality of their responses seemed to indicate how deeply their Jewishness was ccnnected to their parents' Holocaust experiences.

A much larger proportion of children of survivors than controls identify themselves as Jewish in a religious sense. The explanation for this may be two-fold. In the first place, the children of survivors are mainly Eastern European in ancestry, and have more Orthodox roots than controls, whose origins are mostly Reformed and Central 
European. The survivor children may have found, in religiosity, a vehicle for the expression of their Jewish identity that is not available to the controls. Religiosity, moreover, serves, for the children of survivors, as a tie to relatives and ancestors lost in the Holocaust.

There appears to be a very large difference between the controls and the experimental subjects in the amount of active participation in Jewish causes and issues. This finding was in fact expected, but may seem puzzling in view of the fact that there was little difference between children of survivors and controls in their involvement in the Jewish community. The explanation may lie in the fact that conmunity involvenent requires significantly less activity than that necessary for a strong active commitment to social causes and religious issues. It is the vigorous activity that differentiates the controls from the experimental subjects with regard to inyolvement in Jewish causes and issues. A large proportion of children of survivors, because of their Holocaust history, refuse to accept less than a definite and active response to their environment. They are particularly aware that a passive relation to the world might result in another Holocaust. Their active stance in Jewish life is a way of preventing it from ever happening again. 


\section{Suggestions for Further Research and the Practical Implications of this Research}

1) Additional research should be done on non-psychopathological samples of survivor children in order to better understand them. Larger samples might be used to investigate other dependent variables as well as other indepeident variables.

2) "Normal" survivors (rather than clinical samples) themselves need to be investigated, as Dor Shav (1978) has begun to do, in order to throw further light on the effect of Concentration Camps on survivors and their progeny.

3) Study of the "third seneration" survivor must begin, in order to more fully understand the nature of the transmission of trauma and of personality characteristics from parent to child.

4) The conparison of the effects of Holocaust trauma with other types of severe trauma must be undertaken in order to gain further insight into the nature of trauma. (One must always keep in mind the unique nature of the Folocaust.)

5) This study mighi encourage psychotherapists to grapple with the unique dynamics of the survivor offspring rather than with his or her "psychopathology." Special issues do exist for these children of survivors, but they need to be viewed as more "normal" characterological issues rather than deviant ones.

6) Finally, by utilizing the results of this study, intervention programs for survivors and their children may be facilitated. 
Appendix I

\section{Life History Questionnaire}

Purpose of this Questionnalie:

The purpose of this questionneire is to obtain a compreliensive picture of your backsround. By completing these questions as fully and as accurately as you can, you can racilitate the progress of this stuly. This gutsitionnaire will save us both time. You are requested to answer these routine questions in your own tine instead of using up our time together.

It is understandable that you might be concerned about what happens to the information about you, because much or all of this intormation is highly personal. These records are strictly confidential. No outsider, not even your closest relative is permitted to see this questionnaire without your written permission.

If you do not desire to answer ary question, therely writte "Do not care to answer."

Please use the back of the sheets if your response requires more space. Date

1. GENERGL

Name

Address

leiepione Numbers

Age

Occupation

With whom are ycu living? (List people)

Do your parents iive nearby? 
Marital Status: single, engaged, marrled, remarried, seqarated, diverced, widowed (Circle one).

\section{BRRSONAL DANA}

Date of $3 i r t h$ Piace

Pid you have a happl childinood? Expladi.

Wrestith during childhood?

List major illnesses ì any:

Whet is your haigit? Your weight?

Hafe you been foeling emocionally well recently? If not, expiain.

Haxe you been feeling physically well recently? If ict, expiajir.

Heape life elrcumstances been unusually stressful. recently? If so, expiain.

Ganes and interest.s during childhood and aủolescence (Inciuding makebelieve)?

Exesert interests, hobibies, äcivities?

Fov is most of your free time occupied?

Liost advanced level of schooling reacted?

In Eereral, what wis your relationshio with peers in school?

What subject: did yoi do well in?

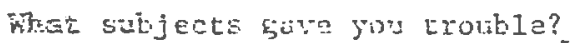

Lo you make friends seasily? Do ynu keep then? 
Are you faqilfar woth the recant 1 therature atd issues concerning children ef Exrvirors? Finch naterials are you familiar with?

\section{OCCUPATIOANAL DATA}

A $g \equiv$ of starting worl:?

List your last three fobs and fow long you worked at them:

Does your present wozk satigfy you? If not, in what ways are you dissetisĩfi?

What is your family income in thousands of dollars?

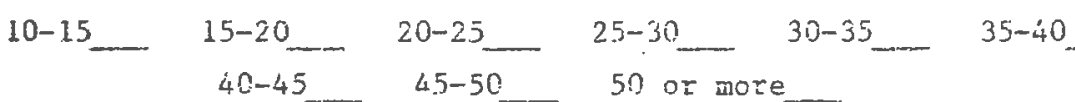

Is the management of money añ issue in your family? Expiain.

\section{MARITAL UISTORY}

Fiow long did you know your spouse before engagenent?

For how long were you engaged? Age of spouse?

How old were you when you married?

In what areas is there most coupatibility between you?

Mccupation of spouse?

Eriefly describe your marriage partner's personality:

is there any fnconpatibility between you? If so, in whet areas? 
Horv do you get aiong with your in-lews (this includes brothers and sistersin-1ev) ?

How hany chilaren have you? Please list them in chronological order with names, ages and sex. Give a brief perscnality description of each.

Are any 0 f the sbove chillren from a former marriage?

\section{FAMILY DATA}

\section{Fathe:}

Dace of birth?

Tf deceased,dace, cause of death, and your age at the tine:

His herith?

Religion? Ceurtry of birth?

City or town ljued in prior to Second world war?

A.pproxinate popuiation of city or town?

occupation prior to second Worid war?

Wher dir father imigrate to U.S.A. (if he is a naturalized ctitizen)?

Was father in Concentration Camp(s)? Which one (s)? For how long?

Fow olct was he when he first entered a camp?

If he wes in a Concentzation Camp, was he also in a Displaced Persons Semp? ____ If yes, for how lorg?

What kijds of problems aid father heve in adjusting to life in the U.S.A.?

\section{Morner}

Date $r i$ Eirth?

If jescasod, date, atres of desth, and your age at the time: 
Her health?

Religion? Country oî birth?

Cicy or town lived in prior to Second World War?

Approxirute popuiation of clty or town?

Occupation prior to Second world War?

When did mother immigrate to J.S.A. (if she is a naturalized citizen)?

Was mother in Concentration Camf(s)? Which one(s)?

For how long?

How old was she when she first entered a camp?

If ehe was in a Corcentration Carap, was she also in a Displaced Persons Camp? If yes, fut how lorg?

What kinds of problems did mother have in adjusting to life in the U.S.A.?

\section{Siblings}

Brothers (Nanes, ages, occupations. Aiso indicate whether they are single, married, divorced, etc.):

Sisters (Names, ages, occupations. Also Indicate whether they are single, married, divorcec, etc.):

Fast relationship with brothers and sisters?

Present relationsinip with brothers and sisters?

\section{Extended Fami.ly}

Do you have pany uncles, aunts, cousins? How many of each on mother's ste?

On fatiner's side?

Do you come from a ciose knit tamily? Detail. 
Give a description of your isther's personaliey and of tis attitude towaras you (past and present):

Give a cescription of your mother's personality and of her attitude towards you (past and prosent):

Do you feel that your parents gave you enough freecom? Were you able to be on your own as murt as you would have liked to be? If no, expiatn.

In what ways were you punfshed by your parents as a thild?

Give an iapression of your hor:e atusphlieite, i.e. the hame in wibich gau gres up. Mention the compatibility between parents and chilauen. 
If you are living with your parents at present, how do you feel about ieaving home?

If you have already left home; was it difficult leaving home when you
a) went away to college
b) got a job
c) sot married Explain.

Note something that is personally important to you and mention how your parents feel about the same issue.

In what ways are you similar to and dffferent from your parents?

Were you able to confide in your parents? Explatis.

Were your parents able to confide in you?_Explain. 
If efther parent was a survivon, was he/she able to communicate openiy about his/her Holocaust experiences? What was the nature of the description? Excessive? Sketchy? Fmotional? Detached? etc.

How much do you know of your parents' experiences during tha period of the Second WorId War? Explain.

If you nave a step-parent, give your age when your parent remarried. Give an outline of your religious training.

Describe the feelirigs your jewishnsss engenders in you.

uave you ever bean in psychotherapy?

When, and for kow long?

If yor were not broight up by your farents, who did bring you up, and betwen what years? 
Has anyone(parents, relatives, friends) ever intarfered in your marriage, occupation, etc.? _____._. If yes, explain.

Wio are the most important people in your life?

Dces any wember of your family suffer from a coholistn, epidepsy, or anything which can be considered a "mental disorder?"

Are there any other rembers of the ianily ebout whot information regarcing i1.jness, etc. is reievant?

Piease make note $k_{e}$ re of any experiences or information you ragard as inportant which has rot alraady been rentioned.

lise the remaining space, and the blank sices of these pages to describe jourself first as you see yourseif, and then as your parents see you. 
Afeendix II

As has been discussed with you on the phone, the major purpose of this study is to investigate the differences (j.f any) batween normal, healthy children of Holocaust survivers and chilcrea of non-survivors (children who heve an iamigrane perent who did not experierce the Hclocaust). It is thoped that we will gajin information about the natura of the survivor's child's experience ana insight into the long range effects of human suffering.

You will be asked to fill out a questionnaire concerning your lifie experiences. This trill take approximately one hour and may be filied out privately at your convenience in your own home. Then, a personality inventory, gesred to detect indiviula differences in a uormal population will be administered. Thís shoulu take approximately ore bour and a halî. Finally, you will be personally interriewed about certein of your attitudes and beliefs. This will require from one half to one hour of your time. The jnterview can take place in your hone at a time convenient to you.

Alchough it is hoped that you will continue until the end of the study, you are free to withdrew your participation at any tire should the investigation be too uncumfortable or time consuming for you. You may also feel free to ask any questions you may have at any foint Juring, the study and to decline to answer yusstione that you feel are too atressfui or rerscnal.

The information that yoil provide will be recorded and aded to thet received Erom othar survivers' chidiren. We will not identify you. All infornation will remain confidential. In the evert of pubication or reporting, you and your fanily will not be identified by name.

Cyathia Eudick has descrlbed to me what is going to be done, now it is going to be done, the risks, hazards and benefits involver, and will be available for questions at 212-362-4527. In the use of information geaerated From these studies, iny identity will rumain anonitious. I am atrare that I may withdraw from this study at any time. I volunzee" to varticipace in this project.

Sigñature Àge Date

parent or Guardien Signsture

Tif subjeet is a minor)

Wڤtressed by (signature ot Project Investigator) Wate 


\section{Appendix III}

As has been dj.scussed with you on the phone, the plajor purpose of this scudy is to irvestigate the differences (if any) between normal, healthy crildren of Holocaust survivors end children of non-survj.vers (children who have an Lunigrant parent who did not axperience the Hoincaust). It is hopeci tirat we will gain information abowt the nature of the survivor's child's experiance.

You will be asked to fill cut a questionnaire concerning ycur life experiences. Thís nili take approwimately ons hour and may be filled out privately st your conveuience in your own hoje. Than, a persorality inventory, geared to detect individual differances in a normal population will be admiristered. This chould take apmroximateiy one hour and a half. Finally, you will be personally interviewed about certain of your attitudes and baliefs. This wili require from one ha!t to one hour of juur time. The interview can cake place in your home at a time corvenient to vou.

Although it is roped that you whll continue until the end of the study, you are iree to withdraw your participation at any time should the investigation be too ucomfortable or time consuning for you. You may also feel. fiee to ask aiy questions you may have at any pojnt during the study and to decline to answer yuestions that you feel are too stresstul. or personal.

The information that you provide will te recorded and added to that received from other chijdren of imnigrant parents. We will. not identify you. All infoxmation will renrin confidential. in the event of pubjication or reporting, you and your family will not be identifled by name.

Cynthia Budick has desczibed to me what f.s going to be done, liow it is going to be done, the risks, hacards and henefits invilvej, and will be aviliable for questions at 2.12-362-4527. In the use of information generated from these studies, my identity wili rengin anonymous. I an aware that I may withdiew from this study at any zine. I volunteer to participate in this project.

Signatiore Age Date

Parent or Guarailan Sigrature

(it jibjeot is a vianor)

Wituessed by

(sigrature of Project Irivestigator)

Dat? 


\section{Appendix IV}

\section{Structured Intervien questions}

I. Mlienation

\section{A. Anomie - 4 Interview Items}

1. Do you feel that the dependable nature of friendship has changed over the years? If yes, how? Please tell the what you mean. İ no, please tell me what you mean.

Do you feel you have strong, enduring friendships? Please explain. Gan you elaborate a little more?

(For Eyperimental Groups Only):

Are you friendly with other children of survivors? Have you always been? What is the general nature of these friandsinps? Does it differ from your relationships or friendships with people who had no indirect experience with the Holocaust?

2. In general, do you feel that true friendship is difficult to attain? why? Please explain.

3. Mny ares we hear a comon complaint that väus are changing so rapiòy ju our society that we can be certain of virtuaily nothing. Ilow do you Eeel abont this?

4. Do you feel that there are still sone absolute guides to coneluct? Expiain.

3. Isolation - 3 Interview Items

1. We periodically hear it said that many people in our society are lonely and separated from their fellow hunan beings. Yyet we also hear that people today seldom feel lonely. How do you feet about this? Where would you place yourself or your om life irith regard to these observations? 
2. I guess there are tines when we all feel isolated and alone in the world. When do you experience these feelings? How do you deal with them?

3. In general, are you comfortabie at social gatherings, or do you sonetines feel awkward and out of place?

\section{Powerlessmess - 3 Intervi.ew Items}

1. There are those who believe that people have a great deal of freedom to make their own cholces, while others feel that the person is severely restricted in his or her freedon. How do you feel about this issue? Can you give ne some examples from your: life?

2. Some say that the horld is run by the few people in power and there is not much the average person can do about i.t. Yet others say that the average citizen can have an impact on government decisicrs. How do you feel about this?

3. People have different ideas and experiences of just how they iit into the affairs of the commity. Would you say that you contribute to commity decisions or that you are not part of the compunity at all, or perhaps, somewhere between these two poles? Please explain.

D. Neaning of Life - 3 Interview Items

1. Every so often we hear a sncjal commentator talk about the increasing complexity and meangiesmese or our lives. How do you feel about this? Do you feel they are right or wrong? Why?

2. Do you yourseye find your personal life fult and pirposerul or do you wish $\dot{x t}$ had more meaning? Please explatin.

3. Do you find yourself vondering about the meming of life? Frequertiy, almost never? Do you feel you do this nore than 
mosi people? Why? Please explain.

II. Social Activism - 6 Interview Items

1. Some people foel that we should suppert the policies of our naticnal leaders on social and political issues regardless of our cwn political views. How do you feel about this?.

2. In cases where your views differ from those of individuals in power, what do you do? Why do you choose these partjcular alternatives?

3. Have you ever been directly involved in activities associated with political or: social movenents? Name of organizations or issues. What have you done, what is your role? Satisfaction, dissatisfaction and why?

4. Do you feel. that you have particularly strong reactions to social injustice? Particulaz issues or times. How do you generally react? Do you feel any personal responsibility to help correct or iriporve the life situation of those who are socially deprived or exploj.ted?

5. Do you feel it necessary to inform or teach others about sociaj. injustice, to make them as aware and as informed as you are?

6. Do you atterpt to set an example for the behavior of others in matters of social conscience? How? Please explain.

rII. Faitin in people (Trust) - 5 Interview Itens

1. Do you feel that most people can be trusted? Can you give me some personal examples?

2. Would you say that nost people tend to help others or are they more incined to look out for themse1ves? Can you explain a little more?

3. Do you think that people who don't watch out for themselves will 
be taken advantage of? Why? How?

4. Do you believe that when you get right down to it, no one is going to care much what happeris to you?

5. From you point of view, do you feel that human nature is basically cooperative or fundanentally competitive? Please explain. 


\section{Aprendix $v$}

SCORING CETTERIA AND GUIDE

I. Alienation is made up of four sub-areas: Anomie, Social Isclation, Powerlessness and Meaninglessness of Life. Each of the responses in each of the subgroups will be rated on a scale of 1 to 5: $1=$ very little, 5 = very much. After scoring individual responses, do a global rating on each of the four sub-areas. Arerage these four sub-area scores to arrive at a total score on Alienation.

A. Anomie: In a state of anomie

1) One does not need Iriends as much as one used to in the past. Friencis are not as important. Friends are no longer so dependable or one is not dependent on friendships. Friendships, in a state of anomje, are neither particularly strong nor enduring.

2) In a state of anomie the noticn would occur that friendship j.s either very difficult or impossibie to attain.

3) In a state of anonie, the feeling is that there is no certainty in socicty, and thet values are rapidly changing.

4) In a condition of anomie, the tendency is to feel that few absolute guides to conduct exit.

Each Aromie question is to be scored: 1) meaning very little ancmie, 2) a little, 3) sone, 4) much, 5) very much. 
B. Social Isolatjon

1) Question 1 is composed of two parts: an isolated individual would tend to see people as lonely and separated from their fellows. In addition, the isolated individual would, bimself /herself, tend to feel. lonely rather than not.

2) This response is difricult to score. A high scores on this question tends to emphasize a general loneliness -a loneliness that is ever present - - and a manner of ohtainjing relief from lonely feelings that do not utilize other people. A high scorer night also emphasize the emotional. piralysis that results from loneliness, and which prevents relief of any kind.

3) The more genera11y unconfortable at social gatherings the individual is, the higher the isclation score. If, for example, an findividual says that hielshe is comfortable at smaller gatherings, his/her score should be somewhere in the niddie.

Each Social Isclation question is to be scored: 1) very little isolated, 2) a Little, 3) some, 4) much, 5) very much.

\section{Powerlessness:}

1) The person who fee.s powerles:s fcels that he/she is very limited in ris/her ability to make cioices, and feels that his/her freedom is restricted by axternals. Attend here to the oxenples giveri, as they can modify the scoring of the question.

2) The individual. who feels poresless will inply that the 
average citizen has litt]e or no infact on government decisions.

3) The person tho feels powerlese will rarely involve himself/herself in community iffairs, since he/she feels that he/she can have very littie impact on the community. If he/she does venture inco communty afiairs, he/she will rarely have an impact-making position. He/she feels weak and powerless.

Each Powerlessness question is to be scored: 1) very little feelings of powerlessness, 2) a little, 3) some, 4) much, 5) very much.

\section{Meanirglessriess of Life:}

1) The individual who finds little meaning in his/her life will strongly agree with this statement. One frequently finds, in the response, a divorce between the ideas of complexity and meaninglessness. The scorer should focls, then, on that part of the response that discusses meaninglessness.

2) The person who leads a meaningiul existence finds his/ her life meaningful and purposeful. One should look careful.1.y at the response to the question of whether hel she wishes his/her life had more meaning. That an individual. wishes his/her life hat nore neaning does not necessarily justify a low score on this question. This may be a fairly fulfilled individual who would simply like his/her life to be even fullcr.

3) If a person wonders about the meaning of life because life appears relaiveiy meaningless to him/her, his/her 
score should be 1ow. If, on the other hand, he/she wonders about the meaning of 1 ife in a positive context, his/her score should be high. The score is not based on whether he/she wonders, but on the content of that wondering. If the response is "no, I don 't wonder", estimate the score on the basis of responses to Questions 1. and 2 .

Each Meaning of Life question is to be scored: 1) very littie feeling that there is little mearing in life (very much meaning), 2) a little (much meaning), 3) some (some meaning), 4) much (1ittle meanjing), 5) very muck (very little meaning).

II. Social Activism: Judge each of the responses on a 1-5 scale; and then do a global rating.

1) Peopie low on the social activism scale would feel that we should support the policies at ledders regardless of our ow political views.

2) People scoring low on this response would do lictle when their views differed from those in power. People scoring higher on tha response tend to take a more active and definite roie.

3) People low on this response have not been involved in activities. Individuals scoring somewhat higher have taken part in those activities that most others of their age and class have participated in. Those scoring tighest are those involved in more djstinctive and unusual activitiss. Important in scoring here is the 
role played: whether a leadership position or not. Satisfaction is not so important since most respondents indicate satisfaction.

4) People scoring low don't have strong reactions, or don't have a real sense of what social injustice is. The low scorer feels little personal responsibility to halp the socially deprived. The higher the score, the stronger the reaction, the greater the specificity of issues, the greater the personal responsibility felt, and the larger the contribution.

5) The low scorer tends not to feel it necessary that he/ she inform or teach others about social injustice. The righer scorer feels thj.s necessity.

6) in indiviciual scores high on this question if he/she attempts to set an example.

Each Social Activism uguestion is to be scored: 1) very little social activian, 2) a little, 3) some, 4) much, 5) very much.

III. Faith in People (Trust): Judge each of the responses on a $1-5$ scale, and tren do a glcbal rating.

1) For a high score, the respondent must unequivocally feel that most peopie can be trusted. The weaker the response, the lower the score. Keep in mind that the personal examples should support the initial respones.

2. For a high soore, the respondent should feel that people teind to help others. The stroiger the tendency to helping others, the higler the score. 
3) A high score here jf the respondent feels that people who don't watch out for themseives won't be taker advantage of.

4) A high score on this question is achieved when the respondent denjes that no one outsile of the immediate family is going to care much what happens to you.

5) A high score if the respondent believes that human nature is basically cooperative.

Each Faith in People questjon is to be scored: 1) very little faith is peuple, 2) a iltile, 3) some, 4) much, 5) very much. 


\section{Appendix. TI}

Departicut of Psycholory University of Rhode Island

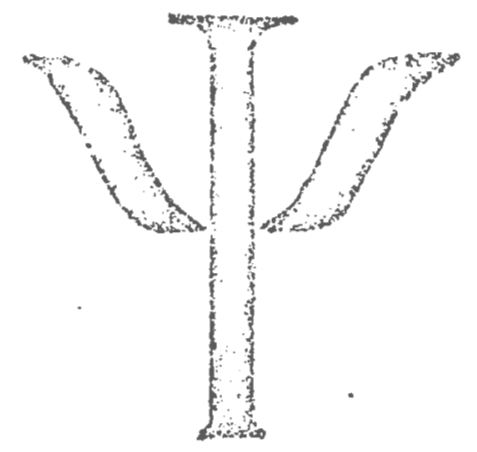

PEPSOMAT ATRIEUTES THVENORY

\section{IRFOUMED CONSFIT}

You have alrealy been informed of the rationale and goals of this research. Your responses to this inventory are stxictly confidontiul. You signify your inforined consent by completing end rewuning this inventory. 
Instructions: FISAB̈ CIRCLE, FOR NACI I'TER, THF WORD THAT MOST NEARLY DESCRIBES THE AMOUNJ OF EEAR YOU FEI TOMARD THE OBTECI OR STTUATTON NOTED IN THE ITEM.

1. Shar objects

None Very Little A I

2. Being a passenger in a car

A Little Solue Much

Very Much

Terror

3. jead bodies
None
Very I.it亡le

A. little

Some

liuch

Very Huch

Terror

4. Suffocating
None
Very Litt.e

A Little

Some

Much

A Littie

Some

A littie

None

Very Little

A Iittle

None Very Little

rplane

7. Being a passenger in a
None Very Little

A Little

Sone

Much

Very Much

Terror

8. Worms None Very Little

A Little

Some

Much

Very Much

Terror

9. Arguing with perents

vone Very Jittle

A Little

Some Much

Very Nuch

Terror

Some Much

Very Much

Terror

10. Rats and zice

None Very Little

A Littie

Some

Much

Very Such

Terror

Sorre

Much

Very Nuch

Terror

11. Thite aster doath

$$
\text { vone Very Iittle }
$$

A Little

Some

Yuch

Very ruch

Terror

12. Hytodondo neorlas None Very Little

A Little

Some

Nuch

Very Nuch

Terror

13. Boing criticised None Vciy Littie

A Littie

Sone

liuch

Very Much

Terror

14. Meeting someone for the first time
None
very tittle

A Little

15. Rolley consters

None Very Litite

A Little

16. Being olore

Fone Very Littile

A Little

A Litile

Some

Much

Very Much

Terror

Some

Much

Very Much

Terror

Soine

Kuch

Very luch

Terror

Some

Much

Very Much

Terror

17. Haling mistakes

$$
\text { None Very Littie }
$$

Some

rinch

Very Much

Terror

18. Heing misulderstood

A littlo

Soine

Much

Very luch

Terror

19. Death

None Vcry Little

A I,ittle

Sone

Much

Very ruch

Terror

20. Being jn a fjekle

hore very liftte

A Litide

Some

x'uci

Very Muc?

Terror

21. Crowded pláces

Nene very Lirtie

A Little

Some

Nuch

Very wuch

Terror

22. 2lood

None Very Litile

A Lititie

Sorve

Much

Very Much

Terror

23. Hejghts None

Very Littie

A Little

Some

Much

Very Wuch

Terror

Terror 
24. Being a lecder

None Very Little

A littlc

\section{Sorve}

Much

A Little

Some

Sich

Very Much

Terror

2.5. Shimining
None

Very I.tetle

A Little

Some

Much

Very such

Terror

None Very Ijtile

A Littre

None Very Little

ones

26. Iliness or injury to

A Little

Some

Much

Very Much

Terror

29. Bejng self-conscious
None
Very I.ittle

A Little

Some

Nuch

Very Much

Terror

30. Driving a car

None Very iittle

A Litele

Some

Much

Very Auch

Terror

31. Neet ing authority

$$
\text { None Very Little }
$$

A Little

Soine

Much

very lích

Terror

A. Iitt1e

Some

Kuch

Very Mach

Terror

32. Mental illness

None Very little

A Littele

Sone

Nuch

Very fuch

Terror

33. Closed placos

yone Very: Iittle

A Little

Sone - Much

Very ruch

Terror

3/4. Boating None Very Littie

A Iittle

Some

Juch

Very Much

Terror

35. Spiders

None Very Little

A Little

Some

Mucil

Very Much

Terror

36. Thunderstormis
lione
Very Ifittle

A Little

Some

Nuch

Very such

Terror

37. Not beirig a success

$$
\text { None Vary Littie }
$$

A Litt.e

Sone

Much

Very Yuch

Terror

4 Iticte

Some

Much

Very Kucin

Terror

rone

A I.ittle

Soine

Much

Very Puch

Terrox:

None Very Little

A Littie

Soine

Much

Very Hach

Terror

None Very Litlle

41. Speaking bolore a groun
Wone:
Very little

42. Seeing a fight

Nione Vexy lititle

A ijtele

Some

A Litt]e

Some

Sucin

Very wuch

Terror

43. Death of a loved oue

None Very i.t.tile

A Littic

Sorae

Much

Very Much

Terror

Terror

44. Dark piacis
Wone Very Little

A ijittle

Sone

Buch

Very Much

Ver $\mathrm{y}$ Huch

Terrot

45. Strange dogs

None Very Little

A Little

Some

$\operatorname{Mach}$

Very $\mathrm{Anch}$

Terrar

46. Deep watex

None Very little

A littic

Much

Very Huch

Terror

Sone

Hich

very Huch

Terror

None very Iittie

A sitic Some

iuch

Very Much

Terror

48. Stinging jnsects

None Veiry littie

$\triangle$ Litile

Sone

Sucl

Very luch

Terror

None

Very litele

A Little

Some

Much

Very Much

Terror 
Losing a job

None Very Litcle

A. Little

Some

Much

Very Ruch

Terror

Auto accidents

None very Litcle

A Ittele

Some

Much

Very liuch

Terror

PART II

Instructions: ON TEE FOILONING PAGES YOU WILL FIND A SERIES OF STATEMENTS INICH A PERSON MICHT USE TO DESCRITE IITSELF. READ EACH STMTEMLNT AUD DECTDE WHETHER OR NOT IT DESCRYBES YOU. THEN INDICAIE YOUR RESPONSE BY CIECLIAG T FOR TRLE OI F FOR FAJSE. JT YOU AGREE WITH A S'IATEHENT OR DICIDE TIAT IT LOES DESCRIDE YOU, ANSHER TRUR. IF YOU DTSAGREE WI'H A STMUMENT OK FEIL TILA IT IS NOT DESCRIPTIVE OF YGU, AYSWER FALSE. ALISWLR TVERY STATEWIE ST EITHER THUE OR FAJSE, EVEE IF YOU ARE HOT CONPLETELY SURE OF YOUR AlSWEK.

1. When soueche rakes a ruIe J don't like I an tempted to break it.

2. When people try to indke me feel tuportant, I. feel guilty and uncomfortable about il.

3. Fven when ry anger js arouged, I don't use "strong; language".

4. I sperc a lot of time visiting friends.

5. I commonly vonder what hidden reason another person may have for dojng something nice for me.

6. I oiten feei like a nowier lieg ready to explude.

7. I än not a "high strurge" perșon.

3. Wnen arguing, I tend to rajse my votre.

9. J.berons upset when soreting intcretes with wy schedule.

10. I am a calm, easy going type of person.

11. I ar only worthy of an inferior position in nost groups.

12. I do everything in my power not to hage to advit defeat.

33. I believe that a person who is incapable of exjoying the people around him misses buch in Iife.

14. I often nave trouble sleeping because I feel so sad.

15. It depresses the that I did not do nore for ray parents.

16. I lijue a vexy happy and satisfyired life.

17. I alvays look forvard to a rew day.

18. I gencrally feel warm encush.

10. I seen to wory about things less than other people do.

20. I frequent? rorry about whether I'n doing ny vork weil.

21. I have a grood cienj. of enerey.

22. I don't know any people that I jowright hate.

23. I to oul of tiy $1: 2 ;$ ico net people.

24. I always appreciate it when peopie are concerned abut me.

25. Whuvex insults ne or my fanily is esking for a fight.

26. I am the kind of person who is alwaye doing errands for others.

27. Occasionally I feel so nexvous that T. begin to get all. choled up.

28. I seldoni go out of thy way to do suncthing jist to make others happy.

29. I an denressed inost of the time. 
30. I have poor blool circulation.

31. If T. let people see the way I feel, I'd be considered a hard person to get along with.

32. I don't vory very much about the future.

33. Peopie have told me that I have very steady nerves.

34. I often find nyself disagreeing with people.

35. Sometimes my legs feel. so weak that $I$ can't walk.

36. I usually solve any problems I mis have and then forget them.

37. There are a number oi people who seem to dislike me very much.

38. I seldon get "liuterilies" in riy stomach.

39. My stomach ts easily upset.

40. I could not put someone in his place, even if he needed it.

41. Sometimes I get: upset about financiel matters.

42. I an consicered friendly.

43. I like to be with people who assume a protective attitude toward me.

44. Once in a wille $m$ stomach feels as if it were tied in knots.

45. I get embarrassec for a speaker who makes a ristake.

46. I woult fecl discouraged and unhapy if soneone I know lost his job.

47. I seldom bother to think of original ways of doing a task.

48. I would rever apoiogize if someone bumped into me and it was his fault.

49. After I get to knom rost people, I decide that they would make poor friends.

50. When I. need money, it rakes me feel good to know that someone can help ne out.

51. When I jook back on what's happened to me, I can't help feeling mildly resentful.

52. I generaily cover up my poor opinion of others.

53. I usually make decisions without consulting others.

54. I think I conld kep myself from vorrying if a friend became ill.

55. I ustally continue doing a new job in exactly the way it was taught to me.

56. I raxejy get upset then somerne c?se nakes a fool of bimstif.

5\%. Wy present situation sechs quite ispe]ess.

58. I can't help getting into arguments when people disagree with me.

59. I can't help being a little rude to poople I con't jike.

60. J. tend to be on my guard with people who are somewhat more friendly than I expected.

61. Once in at wile, I get very upset alout things that have happened in the past.

62. I scretimes feel jittery.

63. J. an not a very excitabie person.

64. I oftcn selk out other people's advice.

65. I an quite content with ny ljfe as it is now.

66. Wheit someorie is bossy, I do the opposite of whit he asks.

67. I prefer not to spend a lot of tiue worrying ajout a person whose condition can't be helpel.

68. I sejdon have pains in odd parts of my body.

69. I have relatively fow friends.

70. At times I feel i get a raw deal out of life.

71. I ari qujte independent of the people 1 know.

72. When I was a rhijd, I usually went co an adult for protection if another child ihreatcred rie.

73. Wher I was a child I allowed other children to take my toys away from me.

74. Nost people think I ara warm-hearted and sociable. 
75. I never get mad enough to throw things.

76. I am Irritated a great deal mora than feopie aro aware cf.

77. Since the age of ten, I have never had a tomper tantrum.

78. I don't let a lot of unimportant things irritate me.

79. Wher I do wrong my conscience funishes me severely.

80. I try to be in the company of Fricnds as much as posstuie.

81. Lateily, I have been kind of grouchy.

82. Soncthing has to be very jmportant before $I$ vorry much about it.

63. People who continualiy pester you are asting for a punch in the nose.

84. Sometimes I get so dizzy I can hardly stand up.

85. I. would never be the "Low man on the tctem pje" if I could heip it.

86. I truly enjoy myself at social Eunctions.

87. I don't waste my sympatry on people who have calised their own protlens.

88. I seldin have a cough or sore throat.

89. J. rould enjoy the chance to make up plots for television prograns.

90. I sclcon fee]. that people are trying to anger ox jnsult me.

91. When $I$ an nad, I sometimes slam boors,

22. T. enjoy almost everytiring I to.

93. If I feel sick, I don't like to heve friends or relatjves fuss over me.

94. I don't trink thirigs will ever get any better for me.

95. I often have eje strain ujun complcting a day's work.

96. I have no patience with someone who is just jooktng for a shoulder to cry on.

97. Un less sumeone asks ne in a nice way, I won't co what they want.

98. I dis1ike almost everything $I$ do.

99. 1 prefer to tale care of things for mosele, rather than have others wa! ch out for he.

100. I sometines polit when I dun't gat my own way.

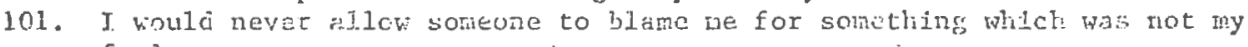
fau?t.

102. I an fitee of aches and pairs.

103. Hy bones give pe no trouble.

104. I sonctimes hive the feoling that others are laughing at me.

305. Loyalty to my friends is quite important to me.

106. There are a number of people who seen to be jealous of me.

107. Wheil $I$ ats waiting for anything, I usually get very anxjous.

108. Almost every week I see soneone I disiike.

109. I telitve that life is worth living.

110. I try to keep out of other people's protlens.

111. I cnjoy bring neibhoriy.

112. I can remewer bejug so angy that $x$ ricked $u_{i j}$ the nearest thing and brolie it.

113. I often think about the possibility of an accident.

Iil. I an perfecty carable of solving my personal problews without consulting anyone.

135. When I see snazare I know fron a distance, I don't so out of ry way to say "Hel. 10 ".

136. When $I$ taji atrout someone I j.jke very wuch, I heve a very hard tome hiding ny forings.

11\%. If someone boesn't treat ne right, I don't lat it annoy me.

T $F$

T. $\mathbf{F}$

T $F$

I. $F$

T $\mathrm{F}$

T $\mathrm{F}$

I $F$

T F

$\mathrm{F}$

$\vec{F}$

$F$

$F$

$F$ 
Instructions: ON THE TOLLONJNG PAGES ARE A SERIES OF 5-POIHT SCALES WT:ICH DESCRIBE A VARIETY OF PSYCHOLOGICAL CHARACTERISTICS. FOR EACH ONT, YOU ARE TO RATE YOUREEIF ON THAT CHLPACTERISTIC. FCR EXMPLE, HOW ARTISTIC ARE YOU? ON THE SCALE BFLOW VLYY SRTISTIC. IS INDICATED AT THE FAR RIGHiT NWD NOT AT ALI ALTISTIC AT THE FAR LEFT.

Not at all artistic

$$
\text { ...A.................... Very artistic }
$$

IF YOU THIRK YOU ARE NODERATELY ARTISTIC, YOUR ANSUER MICHT BE D; IF YOU ARE VERY VNARTJSTIC, YOU SHOULD CHOOSE A, ETC.

FOR EACH SCALE, SELECT THE LETTLR ON THE: SCALE THAT BESE DESCRTPES YOU ARD CLRCLE IHAT LETTER, PLEASE BE SURE TO ANENER EVERY ITEX.

1. Not at asl aggressive

2. Not at all independent

3. Not at all emoticnal

4. Does not hido enotions at a11.

5. Nonconforming to social expectations

6. Not at ail consilerate

7. Not at all easily influenced

8. Very urigratcful

9. Very submissjue

10. Dislikes nath and science very much

11. Poor at sports

12. Not at all excitable jn a majer c2jisis

13. Hot at all excitabie in a minor crisjs

14. Very pastive

15. Not at ali able to devole self completely to others

.16. Very blunt

17. Weak conscience

18. Very rongh

19. Not at all holptui to other:s

20. Not at al1 computitive

21. Vory borre orjented

22. Not at zill skilyed in busiress

23. Knors tie way of the world

24. Not a: a11 kind

25. Inw mechanical aptitude
...A..................Very aggressive

...A...........D........Very independent

...A...B............E....Very emotiona1

.....................AJmost alneys hides emotions

...A...........D........Conforming to social expectations

...A...........D........Very considerate

...................... Very easily iniluenced

...A...E...............Very graterul

..............D....... Very dominane

..................... Likes malh and science very nuch

...A...B...C...D...E....Good at snorts

...................... Very exsitejle in a trajor. crisis

...A...B...C...D.......Vory excitabie in a minor crisis

...A...........D......... very active

...A...................Able to devete self completely to others

...A....................Very tactful

...A....................Very sitrone corscience

...A...B................Very gentle

...A..............E...Very helprul to others

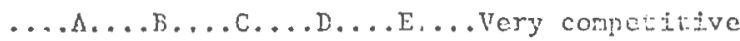

...A...................very worldiy

.......................Very skjijed in business

...A.......C...D....E... Does not know the way of the world

..................E....Very kind ...A.................. High mechanicat aptitude 
26. Indifferent to other's approval

27. Fecljings not easily hurt

28. Not at all adventurous

29. Not at all aware of feelings of others

30. Not at all religious

31. Not at all outspoker

32. Wot at all interested in $\sin x$

33. Can neak decisioris easily

34. Gives up very easily

3.5. Very shy

36. Never cries

37. Alnost never acrs as a leader.

38. Very neat in habils

39. Very qujet

40. Not at ail intellectual

41. Not at all self-conficent

42. Teels very inferior

43. Not at all creative

44. Always sees self as runing. the shot:

45. Always takes a stand

46. Not at all understending of others 47. Very cold ir relations with....................... Very wein in relations with
others

48. Vory little secd for security

49. Not at all anbitious

50. Dislikes children

51. Does not enjoy art and music at all

52. Easily expresses tender feelings

53. Goes to pieces under pressuxe

54. Retiring

55. Not at aj.1 tiniid
...A..................highly needful of other's approva?

...A...........D.......Feelirgs easily hurt

........................Very adventurous

...A...B...............Very aware of feelings of cthers

...A....................Very rel.genous

...A...........D........Very outspoken

...A....................Very interested in sex

..................... Has difficulty naking decisions

...A...B...C...D........ Never gives up easily

...A...................Very outgoiñé

......................Cries vejiy easily

...A..............E...Alnost always acts as a leader

...A..................Very slevey in habits

...A.....................Very loud

...A....................Very intellectual

...A...B...C...D...E....Very selt-confident

...A...B................Feels very superiot ...A...........D........Very creative

.......................Never sces self as running the show

...A....................Never takes a stand

f......................Very understanding of others:

......................Very strong need for security

..............D.......Very arbitous

.......................Likes children

.......................Enjoys art and Iusic very inich

..........C...D........ Does not express tencer feelings at all

...A...........D...E....Stands up well under pressure

.....................Forwasd

......................very tinid 
Instiuctions: ON THC FOLIOHING PACES YOU HILL FIND A SERTES OF STATEMENTS NIICH A PEESOL MLIT USE TO DESCRIBE HIMSELE. READ EACH STATEMENT AND DECIDE: WIEITIER OR NOT IT DESCEIBFS YOU. THEN INUICA YE YOUN RESPONSE BY CIRCLING I FOR TRUE OR F FOR FAISE. IF YOU AGREE WITH A STATHMEAT GR DECIEE THAT IT DOES DESCRIBE YOU, ARSWER THUE. IF YOU DISAGPEE WITH A STATEMENT OR FEE, THAT IT IS HOT DESCRIPTIVE OF YOU, ANSWLR FAISE. AZSUER EVERY STATESENI EITHER TRUE OR FALSE, EVEN IF YOU ARE NOT COSIPLIEIY SURE OF YOUR ANSHEK.

1. I prefer to face my problems by niyseif.

2. People who shirk on the job rust fecl very guilty.

3. Whan I get mad. I say nasty things.

4. I used to think that most people told the truth, but now I know otherwise.

5. I demand that ceople respect my rj.ghts.

6. I an always patien' vith others.

7. If somebody cinroys ne, I am apt to tell him what I think of hin.

b. I usially feej. insecure unless $\mathrm{J}$. am near someone whom I can ask for: support.

9. 1. am concerned about being forgiven for miy sins.

10. I rarely dwe1l on past mistakes.

11. I am usually a happy person.

12. I get short of breath easily.

13. I.ife holcis no interest for tne.

34. I sometimes have bad thoughts which rake me feel ashamed of myself.

15. If I have had an accident, I want sy!npathy írom no one.

1C. Then I am angry;, I sonetimes suik.

17. I often make tireats I don't reajiy mean to carry out.

is. Trying to please peonje is a vaste of time.

19. I vouldn't know where to begin if I had to design a boat.

26. I tend to gez strongly attachej to peoplc.

21. I never play practical jokes.

22. I hardly ever have "splitting" headaches.

23. When $I$ was a child, I disliked it if ny mother was always fussing over me.

24. I. sometimes cerry a chip on my shoulder.

25. I rescnt heirg punished.

26. I get worried when I am expecting soneone and he does not arive on tite.

27. T would rather concede a point than get into an argument about j.t.

22. I like to experiticat with various why of dojng the sane thire.

29. I would rather let others have their way wjth me than try to protest.

30. My motto is "Never trust strangers".

3i. Each day has sene event which hoids my intevest.

32. I have no encaics who realiy wish to harm ne.

33. The theught of being alone in the world frightens me,

34. I lose niy temrer exily but get crer it quiclily.

35. Tu love anci be ioved is of greatest importance to me.

36. I never get too upset about other people's misfortures.

37. I am so sensitive to the moods of my friends that I can almost fecl what they are feeling.

35. My days seem gloony and dull. 
39. I. tend to get quite involved in echer people's proulems.

40. It makes my blood boil to have sonebody make fun of mie.

41. Sometimes people botber me just by being aivound.

42. I. want to remain unhampered by obligations to friencs.

43. I often surprise people with my novel ideas.

44. I an not a very cmotional person.

45. I ari quite affectionate toward people.

46. 1. dun't usually contribute many new ideas to a project.

47. I sometimes spread gossip about peop1e I don't 1.jke.

48. I don't realiy care if. my friends follow my advice or not.

49. I think it would be test to marry soneone who is more mature and less dependent than $I$.

50. I usually teli others of my tilsfortuies because they might be able to assist me.

51. I. do not suffer from backaches.

52. Scmetines I let people push me sxounci so they can frel important.

53. Once in a while I cannot control uy lige to harm cthers.

54. J. don't particklarly enjoy being the object of someone's jokes.

55. I am often very sentinental where my friends are concerned.

56. Althougl I don't show it, I nim scmetimes eaten up with jealousy.

57. I get into fights about as often as the next person.

38. J.t's easy for ge to keep physicaj.ly healthy.

59. Failure gives ne a fecling of renorse.

60. I don't secr to jet what's coring to ine.

61. I tiv not to let anjone elsc toke cradit for my woxi.

62. I at usually very self-sufficient.

63. I can think of no good reason for ever hitting anyulie.

64. I hope to develop a rew techinge in my fjoId CE work.

65. I prefer not being depeident on anyone for assistance.

66. If someone hits the fiust, I let hin iave it.

67. I like to be the first io apologize after an arguruent.

65. Most of my relationchips with people are lusinesi-ije iather them friencily.

6\%. I would not like to be married to a protectsve percon.

70. I vould lile to spend a great deal. of ty time helping less fortunate people.

71. I nevar: seem to be realiy happy.

72. My future is bright.

73. I prefer worit wich requires original thinking.

74. Other people always seem to get the breaks.

75. I usulily feel vary sad when a movic hos ar unhapy ending.

76. I often iry to invent new user for everyday objecis.

77. I rarely feel disappointeo.

72. I lrcov that peonle kend to ta1k about me behind ny tack.

79. I pay 1.itt]e attenticn to the intcrests of peoplc I lnow.

80. I never feel laint.

81. Usually I would rather go sonewhere alone than go to a perty.

82. Original ileas have occirres to ne at almost any time of the day or night.

83. I ofter have infecticus in udd paris of uny body.

84. I enjoy thinling of original plens on which to work.

85. If my house vere robled, I would insist thit the police ruake every eifort to catch the thiaf.

86. There is not much to be interested fin anymore. 
87. Occasionally when I am mad at someone I will Eive him the "silent treatment".

88. Severai people have embarrassed ne publiciy but I always take it like a spoit.

89. When I disapprove of ny frjends' behavjor, I let then know it.

90. I obtain more salisfaction fron mastering a skill than coming up with a new j.der.

91. I sellow strike back, even if someone hits me first.

92. Hy sinin is of ten red and inliamed.

93. I ofler feej. that I have not lived the right kind of life.

94. When people are bossy, I take riy time just to show them.

95. I let penple get ahead of me when wating in line since they probably have sumething moze important to do than I do.

96. If $I$ ever think that $I$ an in danger, my first reaction is to louk for help from someone.

97. I sometimes snow rny anger by banging on the table.

98. I like a job which demands skili and practics rather than inventiveness.

99. Whenever. I an worrjed about something I get cramps.

100. I tuve known peopie who push me so far that we care to blows.

101. I am always seeking new ways to louk at things.

102. When people yell at me, I yell back.

103. I avoid situations which wolld mako me seem inferior.

1.04. When 3 really lose ny temper, 1 am capable of siapping someone.

105. I would dislike hiving to think of new toys ard fames for children.

106. I do not have an especially vivid imagination.

107. I cften get headaches.

108. J don't really think of. myself as a creative person.

109. Peopie cften ask ne for help in creative ectivities.

110. The few times I have cheated I have suffered from ubcarable feclings of reinorse.

111. Others always seeri to enjoy life more than $I$.

112. I. try to keep ny feeiings toward people rather nettral.

113. If I have to resort to physical violence to détend iny rights, I will.

114. 3. sometimes take the blaine for things that aren't really ny fault in order to malie soncone else feel better.

115. I believe that I shail have ry share of́ good luci.

116. I do many things that make ne forl remo-soful afterwards.

11\%. I might be at a loss if I had to design a now book cuver.

118. I would resist anyone who tried to bully me. 
Questions in PART II and PART IV ste reprodiced by permission from the BPI, IPI and FRF, copyright by Louglas N. Jackson in 1976, 1976, and 1965, respectively. 


\section{Appendix VII}

\section{INROVATION - Jackson JPI}

T 1. I. prefer work which requires originaI thinking.

F 2. I would cislike having to think of new toys and games for children.

T 3. I am always seeking new ways to look at things.

F 4. I might be at a loss if I lad to design a new book cover.

T 5. Original ideas have occurred to me at almost any time of the day or night.

F 6. I do not have an especially vivid imagination.

T 7. I enjoy thinking of original plans on which to work.

F 8. I obtain more satisfaction fron mastexing a skj]l than coming up with a new idea.

T 9. People often ask me for halp in creative activities.

F 10. I don't really think of myself as a creative person.

r 11. I often surprise peojle with ny now joleas.

F 12. I don't usually contribute many nen j.deas to a project.

$\mathrm{T}$ 1.3. I often try to invent new uses for everyday objects.

F 14. I like a job which demands skill and practice rather than inventiveness.

T 15. I would enjoy the chance to make up plots for television programs.

F 16. I seldom bother to think of original ways of doing a task.

T 17. I like to experiment with various ways of doing the same thing.

F 18. I wouldn't lnow where to begin if $I$ had to design a boat.

1. 19. I hope to develop a new technique irı my field of work.

F 20. I usually continue doing a new joi in exactly the way it was taught to me. 
F 1. I prefer rot to spend a lot of tine worrying about a person whose condition can't be rieiped.

2. I would feel discouraged and urhappy if someone I know lost his job.

F 3. I don't really care if my friende jollow my advice or not.

T 4. I am so sensitive to the moods of my friends that I. can almost feel what they are feeling.

F 5. I try to keep my feclings toward people rather neitra].

T 6. I vould like to sperd a great deal of my time helping less fortunate people.

F 7. I think I could keep nyself froin worrying if a friend became ill.

T 8 . I am often very sentimental. where my friends are concerned.

F S. I don't waste my sympathy on people who have caused their orn probleins.

I I0. T am quite affectionate toward peopile.

F j.1. I have no patience with soineone who is just looking for a shoulder to cry $\mathrm{cn}$.

T 12. I tend co get strongly attached to people.

F 13. I rarely get upset when soneone else makes a fool of himself.

r 14. I tend to get quite involved in other people's problens.

F i5. I never get too upset about other peop.te's misfortunes.

I 16. When I talk about someone I like very much, I have a very hard time hiding my feeiings.

F 17. I try to keep out of other people's problems.

T 18. I usually feel very sad when a movie has an unhappy ending.

F 19. I am not a very emotional person.

T 20. I get embarrassec for a speaker who makes a mistake. 


\section{ANXIETY - Jackson JPI.}

F I. T an a caln, easy going type of person.

T 2. Wher I an waitjng for anything, I usually get very anxious.

F 3. Something has to be very importart before $I$ worry much about it.

T 4. I get worried when I am expecting someone and he does not arrive on tine.

F 5. People have told me that I have very steady nerves.

T 6. Occasiona11y I Eeel so nervous that I begin to get a11 ciloked up.

F 7. I rareiy dwell on past mistakes.

T 8. I frequently wory about whether I'm doing my work well.

F 9. I usually solve any problens I may have and then forget them.

T 10. I hecome upset when sometling interferes with my schedule.

F 1.1. I em not a "high strung" person.

T 12. Once in a while my stomach feejs as if it were tied in knots.

F 13. I don't worry very much about the future.

$T$ 14. Once in a while, I get very upset about things that have happened in the past.

F 15. T. am not a very excitable person.

$T$ 16. Smietimes I get upset about financial instiers.

F 37. I seem to worry about things less than other peopie do.

T i3. I often think about the possibjlity of an accident.

F 19. I seldom get "butterflies in my storiach".

I 20. I sometimes feel jittery. 


\section{Appendix VIII}

\section{ABASEMENT - PRE-FOrm AA}

T 1. I like to be the first to apologize after ail argument.

F 2. I would never apologize if someone bumped into the and it was his fault.

T 3. Several people have embarrassed me publicly but I always take it like a good sport.

F 4. I do everything in ny power not to lave to admit defeat.

T 5. I sometimes take the blame for things that aren't really my fault in order to make someone else feel better.

F 6. I resent being punished.

I. 7. I would rather let others have their way with me than try to protest.

F 8. I would never allow someone to blame me for something which was not my fault.

T 9. I am the kind of person who is always doing errands for othess.

F 10. I avoid situations which would make me seen inferior.

T 11. When people try to make me feel important, I feel guilty and unccinfortabite about it.

F 12. I try not to let anyone else take credit for my work.

T 13. When I was a child I allowed other children to take my toys away from wie.

F 1.4. T would resist anyone who tried to bully me.

T 15. Sonetimes I let people push me around so they can fee]. inportant.

F 16. I would never be the "Iow inan on the totem pole" if I could help jt.

$T$ 17. I let people get ahead of ne when waiting in a iine since they probably have something inore impoitant to do than I do.

F 18. I don't particularly enjoy being the object of someone's joikes. 


\section{AUTONOMY - PRF-FOYM AA}

T 1. I pay little attention to the interests of people I know.

F 2. I believe that a person who is incapable of enjoying the people around him misses much in life.

T 3. Trying to please people is a waste of tine.

F 4. Loyalty to my friends is quite important to me.

T 5. Most of my relationships witil peopie are business-1ile rather than friendly.

F 6. I an considered friendiy.

T 7 . After I get to know most people, I decide that they would make poor friends.

F 8. I erjoy being neighborly.

T 9. Usually $\mathrm{I}$ would rather go somewhere alone than go to a party.

F 10. I try to be in the company of friends as inch as possibie.

T 11. I have relatively few friends.

$\mathrm{F}$ 12. To love and be Ioved is of great:est importance to me.

$T$ 13. I seldom go out of my way to do something just to make others happy.

F 14. Most people think I am warm-hearted and sociable.

T 15. When I see someone I know from a distance, I don't go out of my way to say 'Iello'.

F 16. I truly enjoy nyself at social functions.

T 17. I want to remain uhampered by ouligations to friends.

F 18. I spend a lot of tine visiting friends.

T 3.9. I an quite independent of the people I know.

2n. I go out of my way to neet people. 
I 19. I am only worthy of an infericr position in most groups.

F 20. If my house were robbed, I would insist that the police make every effort to catch the thief. 


\section{SUCCORANCE - PRE-FOIII AA}

F 1. If I tave had an accident, I want sympathy from no one.

T 2. I always appreciate it when people are concerned about me.

F 3. I am perfectly capable of solving my personal problems without consulting anyone.

I 4. I often seek out other people's advice.

F 5. I would not like to be married to a protective person.

T. 6. When I need money, it makes me fecl good to know that someone can help mle out.

F 7. If I feel sick, I don't like to have friends or relatives fuss over ne.

I 8. I think it would be best to marry someone who is more mature and less dependent than $I$.

F 9. I usually make decisions without consulting others.

T 10. I usually tell others of my misfortunes because they might be able to assist me.

F 11. I prefer not being dependent on anyone for assistance.

i 12. The thoight of being alone in the world frightens me.

F 13. I prefer to face my problems by myself.

T 14. If I ever think that $I$ am in danger, my first reaction is to look for help from someone.

F 15. When I wes a child, I disliked it if my mother was always fussing over me.

T 16. I like to be with people who assume a frotective attitude toward me.

F 17. J. atn usually very self-suffjeient.

$\mathrm{T}$ 18. When I was a child. I usually wat to an adult for protection if amother child threatened nite.

F 19. I prefer to take care of things for myself, rather than have others watch out for me. 
T 20. I usual. Iy feel insecure unless $I$ an near someone whom I can ask for support. 


\section{Appendix IX}

\section{HYPOCHONDRAISIS - BPI-Jackson}

I. It's easy for me to keep physically healthy.

I 2. Soruetimes my legs feel so weak that I can't walk.

F 3. I am free of aches and pains.

1. 4. My stomach is easily upset.

F 5. I seldom have pajis in odd parts of my body.

I 6. I often have eye strain upon conpleting a day's work.

F T. I do not suffer from backaches.

T 8. Whenever I am worried about something I get cramps.

F 9. I seldom have a cough or sore throat.

T 10. I often have infections in oud parts of my body.

F i]. I hardly ever have "splitting" headaches.

T 12. Sometimes I get so dizzy I can hardly stand up.

F 13. I generally fael warm enough.

34. My skin is often red and inflamed.

F 15. My bones give me no troubie.

T 16. I have poor blood circulation.

F 17. I have a good deal of energy.

T 18. I get short of breath easily.

F 19. I never feel faint.

T 20. I often get headaches. 


\section{DEPRESSION - BPI-Jackson}

T 1. My present situation seems quite hopeless.

F 2. I rarely feel disappointed.

T 3. There is not much to be interested in any more.

F 4. My future is bright.

T 5. My days seem gloomy and du11.

F 6. I enjoy a]most everything $I$ do.

T 7. Others always seem to enjoy life more than I.

F 8. Each day has some event which holds tny iriterest.

9. Life holds no interest for me.

F 10. I live a very happy and satisfying life.

T 11. I often have trouble sleeping because I feel so sad.

F 1.2. I always look forward to a new day:

I 13. I don't think things will ever get any better for me.

I 14. I believe that life is worth living.

T 15. I am depressed most of the time.

F 16. I am quite content with my life as it is now.

T 17. I dislike almost everything I do.

F 18. I am usual.jy a happy person.

I 19. I rever seem to be really happy.

F 20. I believe that I shall have my share of good luck. 


\section{Aspeindix X}

ITEMS COMPRISINE BUSS-BURKEE HOSTILITY-GUILT INVENTORY

$$
(F=\text { false iteins) }
$$

\section{Assaint}

1. Once in a while I cannot control my urge to harm others.

F 2. I can think of no good reason for ever hitting anyone.

3. If somebody hits me first, I let him have it.

4. Whoever insults me or my family is asking for a fight.

5. People who continually pester you are asking for a punch in the nose.

F 6. I seldom strike back, even if someore hits me first.

7. When I really lose my temper, I am capable of slapping someone.

8. I get into fights about as often as the next person.

9. If I have to resort to physical violence to deferci my rights, I. wi.1].

10. I have kiown people who pushed me so far that we came to biows.

\section{Indirect.}

1. T. sometimes sprear gossip about people I don't like.

$F \quad$ 2. I never get mad enough to thror things.

3. When I am mad, i scinetimes slam doors.

F 4. I never play practical jokes.

5. When I am angry, I sometines sulk.

6. I sonetimes pout when I don't get my own way.

F 7. Since the age of ten, I have never had a temper tantrum.

8. I can remember being so angry that I picked up the nearest thing and broke it.

9. I sometines show niy anger by banging on the table. 


\section{Irritability}

1. I. lose my temper easily but get over it quickly.

F 2. I am always patient with others.

3. I am irritated a great deal more than people are aware of.

4. It tiakes my blood boil to have somebody make fun of me.

F 5. If someone doesn't treat me right, I don't let it annoy me,

6. Sometimes people bother me just by being around.

7. I often feel like a powder keg ready to explode.

8. I sometimes carry a chip on my shoulder.

9. I can't help being a little rude to people I don't like.

F 10. I don't let a lot of unimportant things irritate me.

1.1. Lately, I have been kind of grouchy.

\section{Iiegativisin}

1. Unless somebody asks me in a njce way, I won't do what they want.

2. When someone makes a rule I don't like I an iempted to break it.

3. When someone is bossy, I do the opposite of: what he asks.

4. When people are bossy, I take my time just to show them.

5. Occasionally when I am mad at soneone I will give him the "silent treatment".

\section{Resentment}

1. I don't seem to get what's coming to me.

2. Other people always seem to get the breaks.

3. When I look back on riat's happred to me, I can't help feeling mildiy resentrul.

4. Almost every week I. seo somoone I lislike.

5. Although I don't show it, I an sometimes eaten up with jealousy. 
F 6. I don't know any people that I downight hate.

7. If I let people see the way I feel, I'd be considered a hard person to get ailong with.

8. At times I feel I get a raw deal out of life.

\section{Suspicion}

1. I know that people tend to talk abovit me behind my back.

2. I tend to be on my guard with people who are somewhat more frierily than $I$ expected.

3. There are a number of peopie who seen to dislike me very much.

4. There are a number of people who seem to be jealous of me.

5. I sonetimes have the feeling that others are laughing at me.

6. My notto is "Never trust strangers."

7. I comionly wonder what hidden reason another person may have for doing something nice for int.

8. I used to think that most people told the truth but now I know rtherwise.

F 9. I have no eneniss who reaily wish to harm ile.

F 10. I seldom feel that people are trying to anger or insult me.

\section{Verbal}

1. When I disappore of my friencs" behavior, I let then know it.

2. I ofter find myself disagreeing with people.

3. I can't help gettine into arguments when pecpie disagree with ine.

4. I deiuand that peopie respect my rights.

$\mathrm{F} \quad$ 5. Even when my anget is arouscd, I don't use "strong Ianguage".

6. If somebody annoys me, I am apt to tell him what I think of him.

7. Whan people yeII at ne, I yell back. 
8. When I get mad, I say nasty things.

F 9. I could not put someone in his place, even if he needed it.

10. I often make threats I don't really mean to carry out.

11. When arguing, I tend to raise my voice.

F 1.2. I generally cover up my poor opinion of others.

F 13. I would rather concede a point than get into an argument about it.

\section{Guilt}

1. The few times I have cheated, I have suffered unbearable feelings of remorse.

2. I sometines have bad thoughts which make re feel dshamed of inyself.

3. People who shirk on the job must feel very guilty.

4. It depresses me that I did not do more for my farents.

5. I am concerned about being forgjven for my sins.

6. I do bany things that make me fael remorseful afterward.

7. Failure gives the a feeling of remorse.

8. When I do wrong, my conscience punishes me severely.

9. I often feel that I have not lived the right kind of life. 

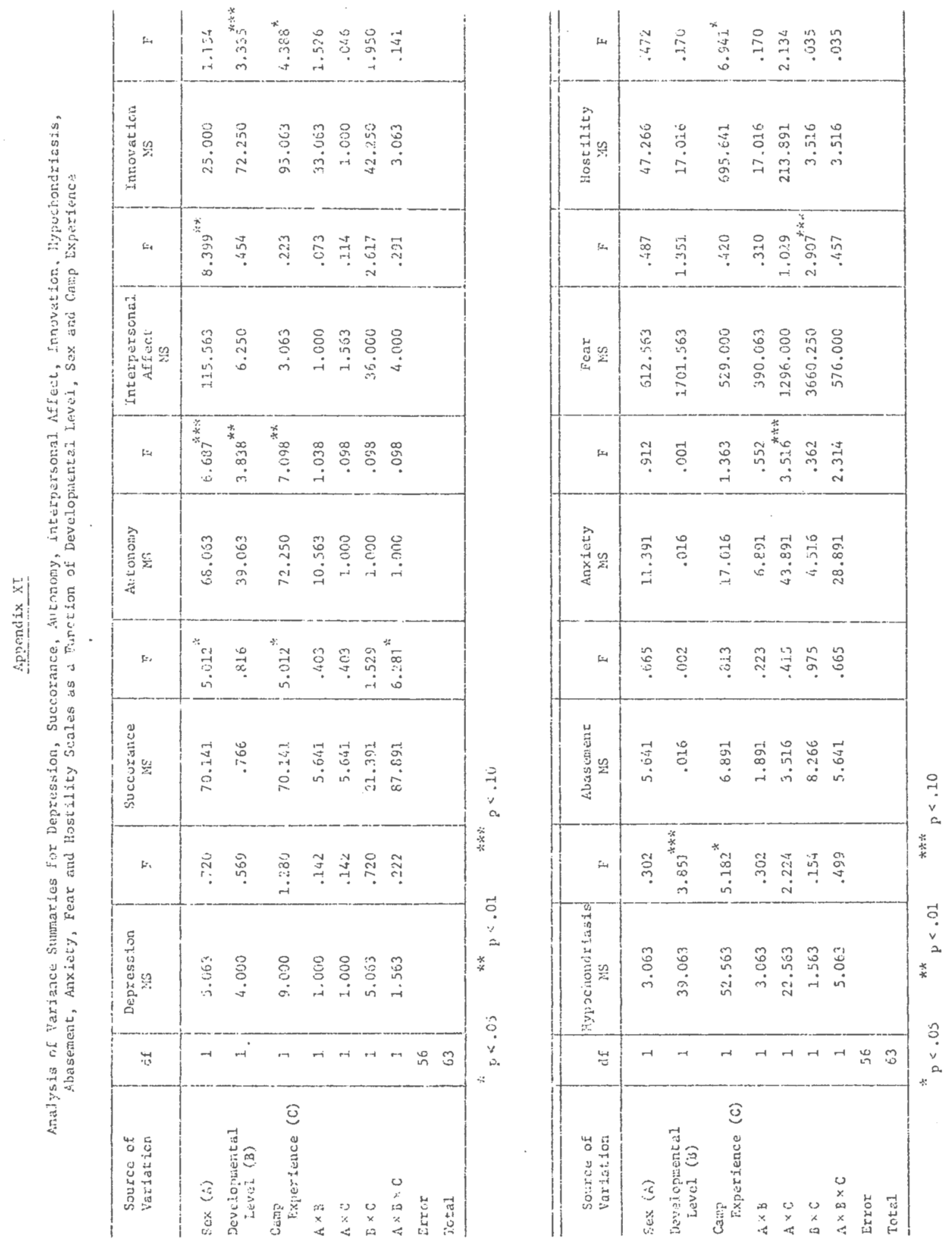


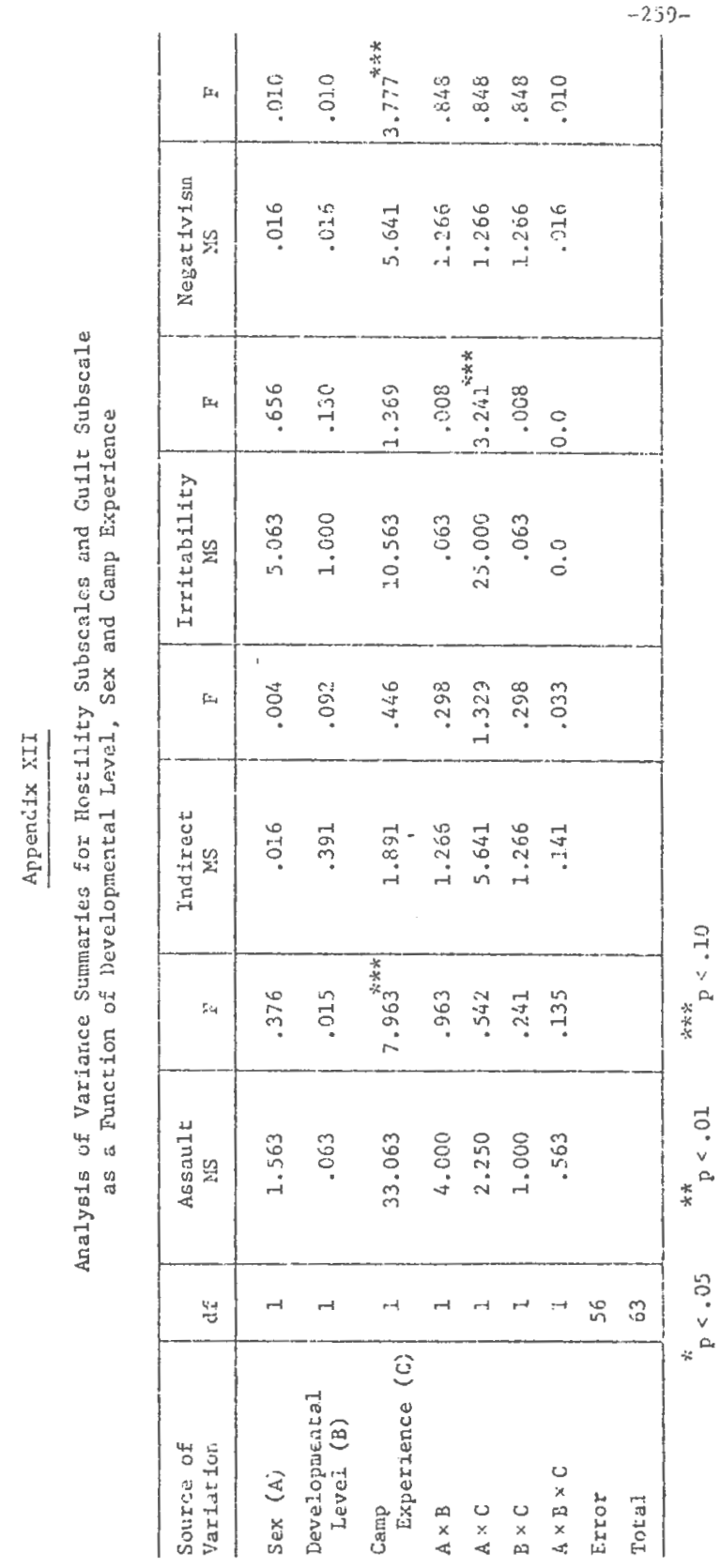

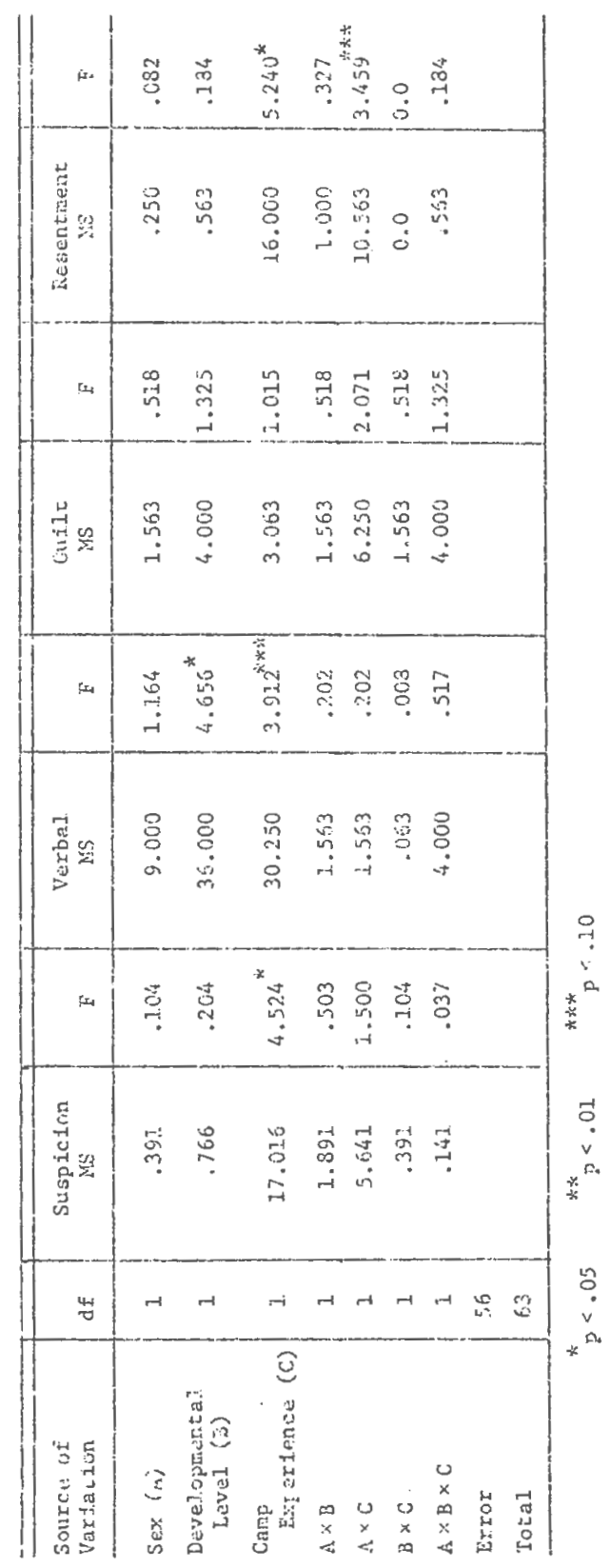




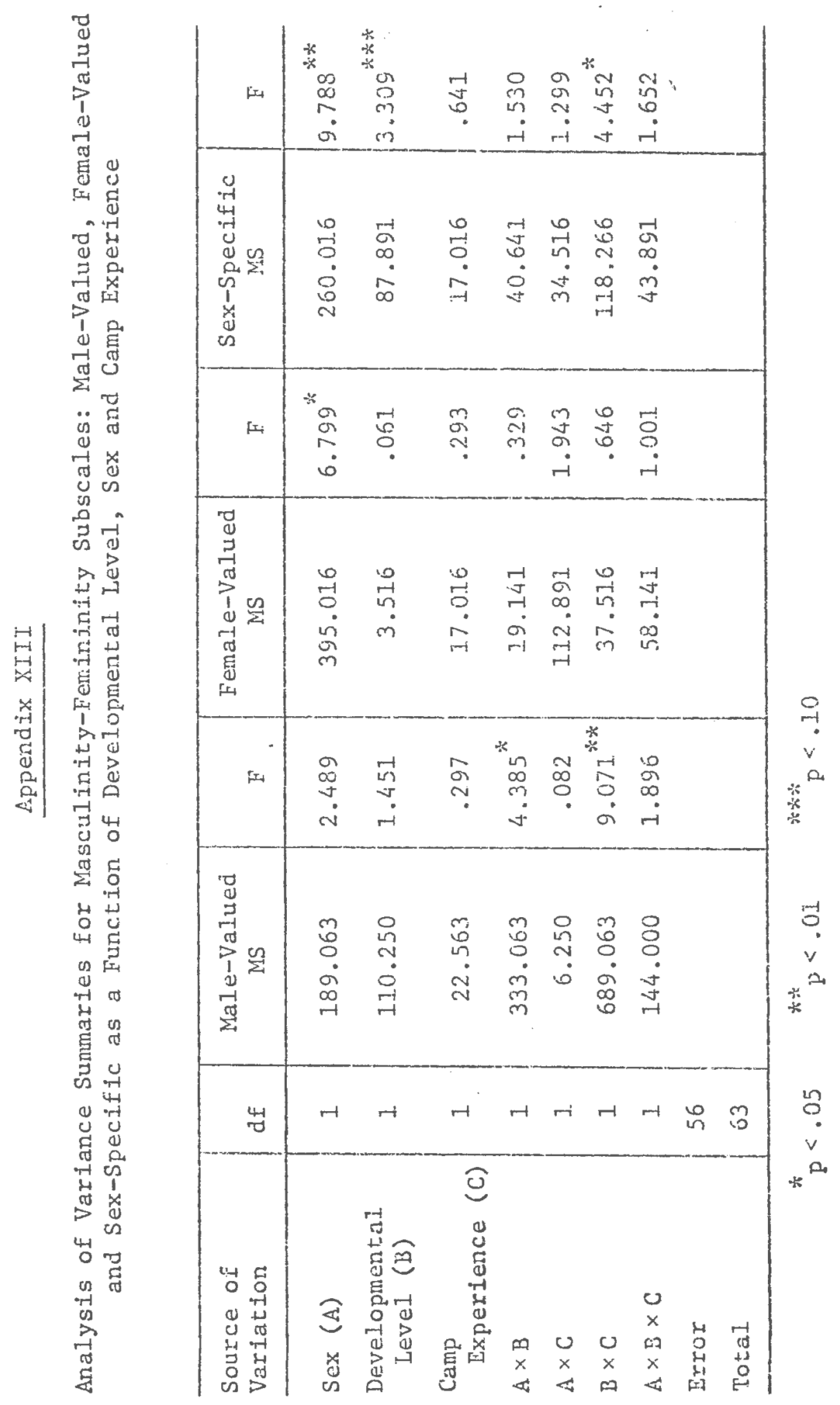




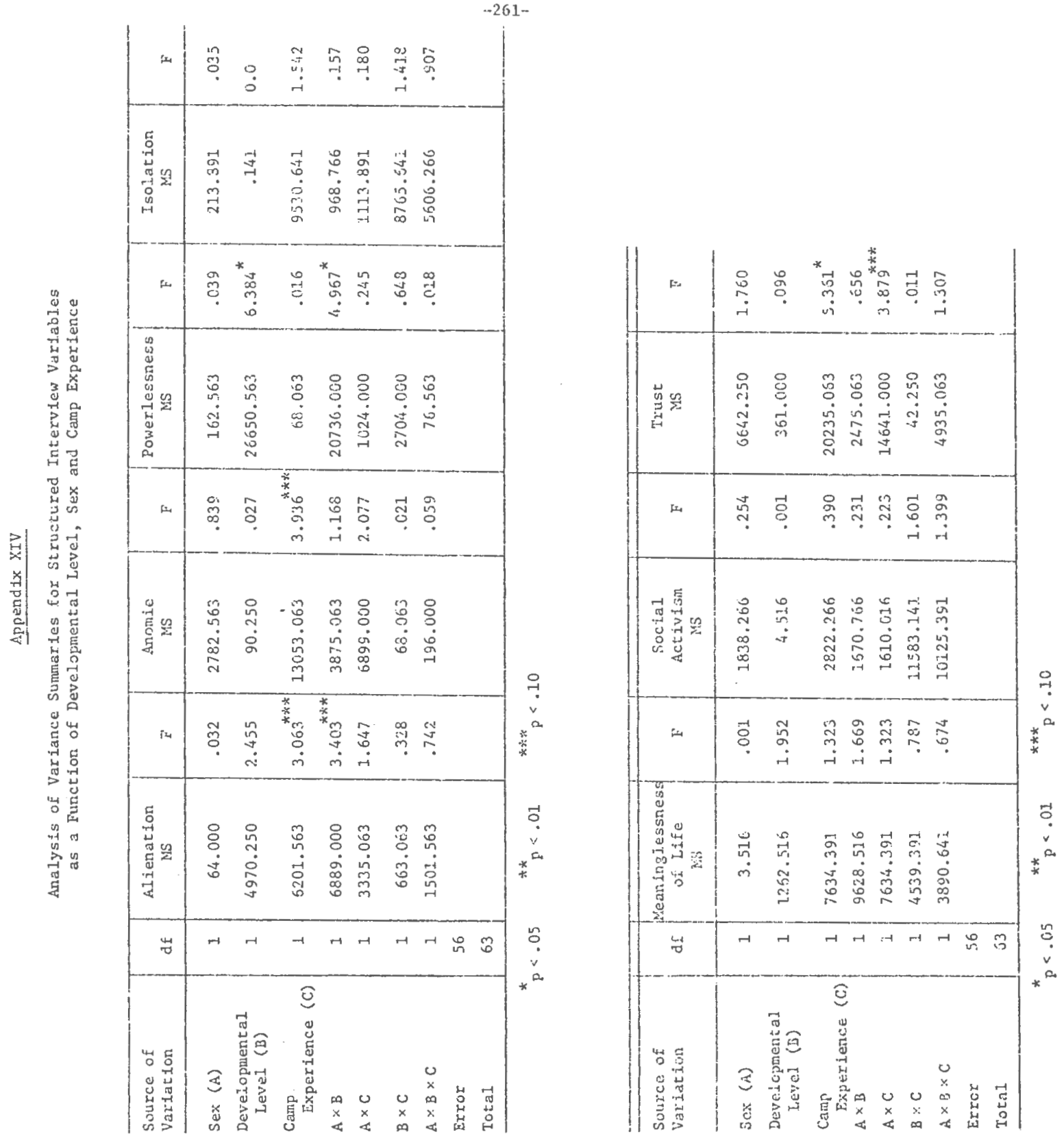




\section{BIBLIOGRAPHYY}

1. Aleksandrowicz, D. (1973). Children of concentration caip survivors. In E.J. Anthony \& C. Kouperaik (Eds.), The Child in His Family (Vol. 2). New York: John Wiley i Sons, Inc.

2. Axelrod, S., Schnipper, 0., \& Rau, J. (1980). Hospitalized offspring of Holocaust survivors. Bulletin of the Menninger Clinic, $44(1), 1-14$.

3. Parccas, P. (1971). A note on the children of concentration camp survivors. Fsychotherapy: Theory, Research and Fractice, 8, 189-190.

4. Barocas, H. (1975). Chiliren of purgatory: reflections on the concentration canp survival syidrome. International Journal of Social Psychjatry, 2I, 87-92.

5. Earncas, H., \& Barocas, C. (1973). Manifestations of concentration camp effects on the second generation. Amerjean journal of Psychiatry, 130, 820-821.

6. Barocas, II., \& Barocas, C. (1979). Wounds of the fathers: the next gentration of Holocaust victins. Internetional Revien of Psychoanaiysis, 6. 331-341.

7. Barocas, II., \& Barocas, 2 . (1980). Separation-individuation conflicts in chilaren of Holocause survivors. Journal of Contemporary Isychothersipy, II(1), o-14.

8. Bergnann, H.S. (1982). Recurrent prozlens in the treatuent of survivors and their children. In M.S. Bexgnann \& M. Jucovy (Ëas.), Generations of the Holocaust. New York: Busic Books, Jnc.

9. Bergnanii, M.S., G Jucovy, M. (1982). Prejule. In M,S. Bergnann M. Jucory (Eds.), Generations of the rolocaust. New York: Basic Books, Ine.

10. Bergmann, H.S.: \{ucovy, W. (1982). Epjlogue. In M.S. Bergmann \& M. Jurovy (Eds.), Eenerations of the llolocaust. New York: Basic Books, ince.

11. Bergmann, M.V. (1982). Thoughts on superego pathology of survivors and their children. In M.S. Pargnann \& M. Jucovy (Eds.), Generations of the llolocaust. New York: Basic Books, Inc.

12. Blos, P. (1962). On Adolescence: A Psychomalytic Interpetatior. Ner York: The Fres Press of Glencove, ine.

13. Brody, S. (1973). The son of a rerugee. Peychoanalyeic study of the Cinill $28, \quad 269-191$. 
14. Buss, A., \& Durkee, A. (1957). An inventory for assessing different kinds of hostility. Jcurnal of Consulting Psychology, 21, 343-349.

15. Bychowski, G. (1968). Pemanent character changes as an aftereffect of persecution. In H. Krystal (Ed.), Massive Psychic Trauma. Ner York: Internatjonal Universities Pres\$.

16. Campell, D., \& Stanley, J. (1963). Experimental and QuasiExperimental Designs for Research. Chicago: Rand McNally College Publishing Company.

17. Cannel1, C., \& Kahn, R. (1968). Interviewing. In Lindzey \& Aronson (Eds.), The Handbook of Social Psychology (2nd ed.), (Vol. 2, pp. 526-595). Massachusetts: Addison-WesIey.

18. Chodoff, D. (1966). Efferts of extreme coercive and oppressive forces -- brainwasting and concentration camps. In S. Aricti (Ed.), American Handbook of Psychiatry (Vol. 3). New York: Basic Books.

19. Chodoff, P. (1980). Psychotherapy of the survivor. In J. Dimsdale (Ed.), Survivors, Victims, and Perpetrators: Essays on the Nazi Holocaust. New York: Hemisphere Publishing Corporation.

20. Cook, T., \& Campe11, D. (1979). Quasi-Experimentation: Design and Analysis Issues for Field Settings. Chicago: Rand McNa1ly College Publishing Company.

21. Cone, J., \& Hawkins, R. (1977). Behavioral Assessment: New DirectIons in cilnical. Psychology. New York: Bruner/Mazel, Inc.

22. Danieli, Y. (1980). Countertransference in the treatment and study of Naz1 Holocaust survivors and their chiidren. Victinology: An Internationa 1. Journa 1, $\underline{5}(2-4), 3.55-367$.

23. Danieli; Y. (1.980). Families of survivors of the Nazi. Holocaust: scme long and short term effects. In N. Milgram (Ed.), Psychological Stress and Adjustment in Tjme of War and Peace. Washington, D.C.: Hemisphere Publishing.

24. Danto, B. (1968). The role of "mlssed adolescence" in the etiology of the concentration camp survivor syndrome. In $\mathrm{y}_{\text {. Krystai (Ed.), }}$ Massive Esychic Trauma. New York: International Universities Press.

25. de Graaf, T. (1975). Pathological pacterns of identification in fanilies of survivors of the Holocaust. The Israel. Annals of Psychiatry and Related Disciplines, $13(4), 335-363$.

26. Des Pres, T. (1976). The Survivor: An Anatomy of Life in the Death Camps. New York: 0xford University Press.

27. Dinsiale, J. (1978). Coping -- every man's war. American Journal of Psychotherapy, 402-413. 
28. Dimsdale, J. (1980). The coping behavior of Nazi concentration camp survivors. In J. Dimsdale (Ed.), Survivors, Victins, and Pernetrators: Essays on the Nazi Holocaust. New York: Henisphere Publishing Corporation.

29. Nor-Shav, N. (1978). On the long-range effects of concentration camp internnent on Nazi victins: 25 years later. Jouznal of Consulting, anci Clinical Psychology, 46(1), 1-1.l.

30. Eitinger, L. (1963). Preliminary notes on a study of concentration cainp survivors in Norway. The Israel Arnals of Psychiatry and Related Disciplines, $1,59-\overline{67}$

31. Eitinger, L. (1981). Organic and psychosomatic aftereffects of concentration camp imprisonment. International Psychiatry clinics, $8,205-215$.

32. Eitinger, L. (1980). The concentration camp syndrone and its late sequelae. In J. Dimsdale (Ed.), Survivors, Victims, and Perperrators: Essays on the Nazi Holocaust. New York: Hemisphere Publising Corporation.

33. Hitinger, L. (1981). Studies on concentration cainp survivors: the Norwegian and global contexts. Journal of Psychology and Judaism, $6(1), 23-32$.

34. Epstein, H. (1979). Children of the Holocaust. New York: G.P. Putnats's Sons.

35. Fink, H. (1968). Deveiopment as a result of Nazi persecution during adolescence. International Journal of Fsychoanalysis, 49 $(2-3), 327-329$.

36. Fogelnan, E., E Savran, B. (1979). Therapeutic grours for children of Holocaust survivors. International Jowrnal of Groui Foychotheraty, 2.?. 2.11-236.

37. Fogelinan, F. \& Savran, B. (1980). Brief group therapy with offspring of Holccaust survivors: leaders' reactions, American Journal of orthopsychiatry, 50(1), 96-jo8.

38. Freud, A. (1946). The Ego and the Mechanisms of Defense (Ch. IX, XI, XTI). International Jriversities Press. Ine.

39. Freud, A. (1949). On certain difficulties in the preadolescent's relations to his parents. Die Psychotherapie. Bern: Huber.

40. Freud, A., \& Dann, S. (1951). An experinent in group upbringing. Psyrloanalytic Study of the Child, 6, 16.3-229.

41. Freud, A. (1958). Adolescence. The Psychoanalytic Study of the Ciniti, 13, 255-2.78. 
42. Frcy, P. (1978). Science and the single case in counceiting research. Personnel. and Guidance Journa1, 56, 263-268.

43. Freyberg, J. (1980). Difficulties in separation-individuation as experienced by offspring of Nazi Holocaust survivors. American Journal of Orthopsychiatry, 50 (1), 87-9.5.

44. Furman, F. (1973). A contribution to assessing the role of infantile separation-indivjduation in adolescent development. Psychoanalytic Study of the Child, 28, 193-207.

45. Furnan, E. (1973). The impact of the Nazi concentration camps on the children of survivors. In E.J. Anthony \& C. Koupernik (Eds.), The Child in His Family (Vol. 2). New York: John Wiley and Sons, Inic.

46. Gampe1, Y. (1982). A daughter of silence. In M.S. Bergmann \& M. Jucovy (Eds.), Generations of the Holocaust. New York: Basic Broks, Inc.

47. Geer, J. (2965). The development of a scale to measure fear. Beriav. Res. Ther., 3, 45-53.

48. Goldman, I. (1977). Toward more meaningful research. Personnel and Guidance Journal, 55, 363-368.

49. Grubich-Simitis, I. (1981). Extreme traumatization as cumilative trauma: psychoanalytic investigations of the effects of concentration carp experiences on survivors and their chiloren. Psychoanalyt-ic Study of the Child, 36, 415-450.

50. Gyomrot, E.L. (1963). The analysis of a young concentration camp victim. Psychoaialytic Study of the Chilici, 18, 484-510.

51. Heller, D. (1982). Themes of culture and ancestry anong children of concentration camp survivors. Psychiatry, 45(3), 247-261.

52. Herzog, J. (1982). World beyond netaphor: thoughts on the transmission of triuna. In M.S. Hergmann \& M. Jucovy (Eds.), Generations. of the Holucaust. New York: Basic Books, Inc.

53. Hoppe, K. (1962). Persecution, depression and aggresstor. Menninger Clinic Bulletin, 25, 195-203.

54. Hoppe, K. (1966). The psychodynamies of concentration camp victims. Psychoanalytic Forum, 1(1), 75-85.

55. Hoppe, ‥ (19;1). The arternath of Nazi persecution refleated in recert psychiatric Iilerature. International Esychiatry Clinics, $169-204$.

56. Jackson, D.H. (1974). Personality Rescaxcin Form Menual. Goshen, New York: Researeh Poychologisis press. 
57. Jackson, D.H. (1976). Iacksorn Perscnality Inventory Manua1. Port Huron, Michigan: Research Psychologjsts Press.

58. Kerlinger, F. (1973). Foundations of Eehavioral Research. New York: Holt, Rinehart and Winston, Inc.

59. Kestenberg, J. (1972). Psychoanalytic contributions to the problem of children of survivors from Nazi persecution. The israel Anrals of Fsychiatry and Related Disciplines, 10, 311-325.

60. Kestenberg, J. (1973). Introductory remarks: children of the Holocaust. In E.J. Anthony \& C. Koupernik (Eds.), The Child in His Family (Vol. 2). New Yotk: John Wiley and Sons, Inc.

61. Kestenberg, J. (1980). Paychoanalyses of children of survivors from the Holocaust: case presentations and assessment. Journal of the American Psychoanalytic Association, 28(4), 775-804.

62. Kestenberg, J. (1982). A metapsychological assessment based cn an analysis of a survivor's child. In M.S. Bergmann \& M. Jucovy (Eds.), Generations of the Holocaust. New York: Basjc Books, Inc.

63. Kestenberg, J. (1982). Survivor-parents and their chilìiren. In M.S. Bergmann \& M. Juc ovy (Eds.), Generations of the Holocaust. New York: Basic Books, Inc.

64. Kestenberg, J. \& Kestenberg, M. (1982). The background oi the study. In M.S. Bergmann \& M. Jucovy (Eds.), Generations of the Holocalist. New York: Basic books, Inc.

65. Kestenberg, J. \& Kestenberg, M. (1982). The experience of survivor parents. In M.S. Bergmann \& M. Jucovy (Eds.), Generations of the Holocaust. New York: Basic Books, Jnc.

66. Kinsler, F. (1981). Second generation effects of the Holocaust: the effectiveness of group therapy in the resolution of the tiransmission of parental trauma. Journal of Psychology and Judaism, $6(1), 53-67$.

67. Kilduff, R., \& Velicer, W. Reliabil1ty and faking susceptibility of the basic personality inventory. Unpublished manuscript.

68. Klein, H. (1971). Holocaust survivors in the kibbutz. International Psychiatry Clinics, 8, 67-92.

69. K1ein, H. (1972). Holocaust survivors in kibbutzin: readaptation and reintegration. The Israel Annals of Psychiatry and Related Disciplines, $10,78-91$.

70. KJ.ein, H. (1973). Children of the Holocaust: mourning and bereavement. In E.J. Anthony \& C. Koupernik (Eds.), The Child in His Famfly (Vol. 2). New York: John Wiley and Sons, Inc. 
71. K1ein, H. (1974). Delayed effects and after-effects of severe traumatization. Israel Annals of Dsychiatry, 12, 293-303.

72. Klein, H. (1974). Child victims of the Holocaust. Journal of Clinical Child Psychology, 3, 44-47.

73. Kiein, H., \& Last, U. (1974). Cognitive and enotional aspects of the attitudes of American and Israeli youth towards the victims of the Holocaust. The Israel Annals of Psychiatry and Related Disciplines, 12, 111-131.

74. Koenig, W. (1964). Chronic or persisting identity diffusicn. American Journal of Psychiatry, 120, 1081-1083.

75. Krystal, H. (1968). Massive Psychic Trauma. New York: International Universities Press.

76. Krystal, H. \& Niederiand, W. (1968). Clinical observations on the survivor syndrome. In H. Krystal (Ed.), Massive Psychic Irauma. New York: International Unfversities Fress.

77. Krystal, H. (1971). Trauma: considerations of its intensity and chronicity. International Psychiatry Clinics, 8, 11-28.

78. Krell, R. (1979). Holocaust families: the survivors and their children. Comprehensive Psychiatry, 20(6), 560-568.

79. Kuperstein, E. (1981). Adolescents of parent survivors of concentration cenps: a.review of the literature. Jourral of Psychology and Judiasin, $6(1), 7-22$.

80. Laufer, M. (1973). The analysis of a child of survivors. Ir. E.J. Anthony s C. Koupernik (Eds.), The Child in His Fanily (Vol. 2). New York: John Wiley and Sons, Inc.

81. Leon, G., Butcher, J., K1 einman, M., Goldberg, A., \& Almagor, M. (1981). Survivors of the Holocaust and theix children: current status and adjustment. Journal of Personality and Social Psycho$10 \mathrm{lg}, 41(3), 503-516$.

82. Lifton, R.J. (1980). The concept of the survivor. In J. Dimsdale (Ed.), Survivors, Victims, and Perpetrators: Essays on the Nazi Holocaust. New York: Hemisphere Publishing Corporation.

83. Lipkowitz, M.H. (1973). The child of two survivors: a report of an unsuccessful therapy. The Israel Annals of Psychiatry and Related Disciplines, $11,141-155$.

34. Loevinger, J. (1966). The meaning and measurement of ego development. American. Psychologist, 21, 195-206.

85. Loevinger, J., \& Wessier, R. (1970). Measuring Ego Development I. San Francisco: Jossey-Bass. Inc. 
86. McReynolds, P. (1968). Advances in Psychological Assessment (Vol. I). California: Science and Behavior books, Inc.

87. Mckeynolds, P. (1971). Advances in Psychological Assessnent (Voi. II). California: Science and Behavior Books, Inc.

88. McReynolds, P. (1978). Advances in Psychological Assessment (VoI. IV). San Francisco: Jossey Bass Inc.

89. Meeks, J.E. (1971). The Fragile Alliance (pp. 3-31). Baltinore: The Wiliziams and Wilkins Company.

90. Mouss, R.E. (196́8). Thecries of Adolescence (pp. 36-55). New York: Random House.

91. Nathan, T.S., Ej.tinger, L., \& Winnik, H.Z. (1.964), A psychiatric study of survivors of the viaj Holocaust: a study in hosjicalized patients. The Israel Annals of Psychiatry and Related Disciplines, $2,47-80$.

92. Nemeth, M. (1971). Psychosis in a concentration camp survivor. International Psychiatry Ciinics, 5 , 135-146.

93. Nrman, L. (1979). Enotional disturbance in children of Holocenst survivnrs. SoclaI Casework: The Journal of Contamporary Social Work, 43-50.

94. Niederland, W. (1968). The problem of the survivor. In H. Krysta1 (Ed.), Massive Psychic Tranna. New York: International Universities Press.

95. Nierierland, W. (1968). An Jnterpretation of the psychological stresses and defenses in concentration camp life aric the late after-effects. In H. Krystal (Ed.), Massive Psychic Trauma. New York: International Universities Press.

96. Niederland, W. (1971), Introductory notes on the concept, definition, and range of psychic trauma. International Psychiatry Clinics, 8, 1-9.

97. 01iner, M. (1982). Hysterical features among children of survivors. In M.S. Bergnann \& M. Jucovy (Eds.), Generations of the Holocalist. New York: Basic: Books, Inc.

98. Phillips, R. (1978). Impact of Nazi Holocaust on children of survivors. Anerican Journal of Psychetherapy, 370-378.

99. Porter, J. (1932). Is there a survivor's syndrome? Psychological and socio-political implications. Journal of Psychology and Judaism, 6(1), $33-52$.

100. Prince, fie (1980). A casf study of a psychonistorical figure: The influence of thic Holccaust on identity. Journal of: Contemporary 
Psychotherapy, 11(1), 44-60.

101. Rabinowitz, D. (1976). New Lives: Survivors of the llolocaust Living in America. New York: Alfred A. Knopt.

102. Rooinson, J. \& Shaver, P. (1973). Measures of Social Psychological Attitudes. Ann Arbor, Michigan: Institute ror Social Research, The University of Michigan.

103. Robinson, S. (1979). Late effects of persecution in persons who -ás children or young adolescents -- survived Nazi occupation in Europe. Israel Annals of Psychiatry and Related Disciplines, $17(3), 209-213$.

104. Rosenberger, L. (1973). Children of survivors. In L.J. Anthony \& C. Koupernik (Eds.), The Child in His Farily (Vol. 2), New York: John wiley and Sons, Inc.

105. Russel1, A. (1974). Late psychological consequences in concentration camp survivor fanilies. American Journal of Orthopsychiatry, 44(4), 611-619.

106. Russe11, A. (1980). Late effects-influence on the children of the concentration camp survivors. In J. Dimsdale (Ed.), Survivors, Victims and Perpetrators: Essays on the Nazi Holocaust. New York: Heraisphere Publishing Corporation.

107. Rustin, S. (1971). Guilt, hostjlity and Jewish identification among a self-seiected sample of late adolescent chilkiren of Jwish concentration camp survivors: a descriptive study. Dissertation. Abstracts International, 32(3): Order No. $71-24,810$.

108. Rustin, S. (1980). The legacy is loss. Journal of Contenporary Psychotherapy, 1I(1), 32-43.

109. Sachs L., \& Titicvsky, J. (1.967). On identification with the aggressor: a clinical note. The Israel Annals of Psychiatry and Related Disciplines, 5, 181-184.

110. Schneider, S. (1978). Attitudes toward death in adolescent off-spring of Holocaust survivors. Adolescence, 13(52), 575-584.

111. Schneider, S. (1931). A proposal for treating adolescent offspring of Holocaust survivors. Journi of psychology and Judaisn, $6(1), 68-76$.

112. Scott, W.A., \& Wertheimer, M. (1965). Introduction to PsychologiCal Research. New York: John Wjiey and Sons, Inc.

113. Shengold, L. (1979). Child abuse and deprivation: soul murder. Journal of the American psychoanilytic Association, 27, 533-559. 
114. Sigal, J. (1971). Second generation effects of massive psychic trauma. International Psychiatry Clinics, 8, 55-65.

115. Sigal, J. (1973). Hypotheses and methodology in the study of families of the Holocaust survivors. In E.J. Anthony \& C. Koupernik (Eds.), The Child in His Family (Vol. 2). New York: John Wiley and Soris, Inc.

116. Sigal, J., Silver, D., Rakoff, J., \& Ellin, B. (1973). Some second generation effects of survival of the Nazi persecution. American Journal of Orthopsychiatry, 43, 320-327.

117. Siegel, L. (1980). Holocaust survivors in Hasidic and litraorthodox Jewish populations. Journal of Contemporary Psychotherapy, 11 (1.), 15-3.1.

118. Slipp, S. (1979). The children of survivors of Nazi concentration camps: a pilot study of the intergenerational transmision of psychic trauna. In L. Wolberg \& M. Aranson (Eds.), Group Therapy: an Overview. New York: International Universities Press.

119. Solkoff, N. (1981). Children of survivors of the Nazi Holocaust. American Journal of Orthopsychiatry, $5(1), 29-42$

120. Solkoff, N. (1982). Survivors of the Holocaust: a critical review of the 1iterature. Selected Documents in Psychology, Ms. 2507, Washington, D.C.: The American Psychological Association.

121. Sonnenberg, S. (1974). Norkshop repcrt: children of survivors. Journal of the American Psychoanalytic Association, 22, 200-204.

122. Spence, J., Helmreich, R., \& Stapp, J. (1984). The personal attributes questionnaire: a measure of sex roles stereotypes and másculinity-femininity. Selected Documents in Psychology, Ms, 617, Washington, D.C.: The fmerican Psychologicai Associaticn.

123. Sterba, E. (1968). The effect of persecution on adolescents. In H. Krysta1 (Ed.), Massive Psychic Trauma. New York: Internationa 1 Universities Press.

124. Stolorow, R., \& Iachman, F. (1975). Early object loss and denial: developmental considerations. Fsychoanalytic Quarteriy, 44 , 596-611.

125. Thoreson, C. (1978). Making better science, intensively. PersonneI and Guidance Journal, 56́, 279-282.

126. Trautman, E. (1971). Violence and victims in Nazi concentration camps and tile psychopathology of the survivors. International Psychiatry Clinics, 115-133.

127. Trossman, B. (1968). Adolescent children of concentration camp 
survivors. Canadian Psychiatric Association Journal, 12, 121-123.

128. Tuteur, W. (1966). One hundred concentration camp survivors twenty years later. The Israel Annals of Psychiatry and Related Disciplines, $4,78-90$

129. Wanderman, E. (1976). Chilaren and families of Holocaust survivors: a psychological overview. In L. Steinitz \& D. Szonyi (Eds.), Living After the Holocaust: Reflections by the Post-War Generation in America. New York: Biloch Publishing Company, Inc.

130. Wiesel, E. (1969). Night. New York: Discus Books.

131. Winnik, H.Z. (1967). Psychiatric disturbance of Holocaust (Shoa) survivors: symposium of the Israel Psychoanalytic Society. The Israel Annals of Psychiatry and Related Disciplines, 5, 91-100.

132. Winnik, H.Z. (1967). Further conments concerning problems of late psychopathological effects of Nazi.persecution and their therapy. The Israel Annals of Psychiatiy and Related Disciplines, 5, 1-16.

133. Zlotogorski, Z. (1983). Offspring of concentration camp survivors: the relationship of perceptions of family cohesion and adaptability to levels of ego functioning. Comprehensive Psychiatry, 24(4), 345-354. 